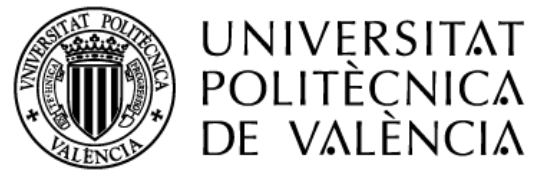

Programa de Doctorado en Ciencia,

Tecnología y Gestión Alimentaria (RD 99/2011)

\title{
OPTIMIZATION OF POSTHARVEST TECHNOLOGY FOR 'ROJO BRILLANTE' PERSIMMON AND INTRODUCTION OF NEW VARIETIES IN THE MEDITERRANEAN AREA
}

PhD Thesis

Presented by:

Ayoub Fathi Najafabadi

Thesis supervisors:

Ph.D. Alejandra Salvador Pérez

Ph.D. Cristina Besada Ferreiro

Academic tutor:

Ph.D. Isabel Hernando Hernando

Valencia, March 2021 

"I can do things you cannot, you can do things I cannot; together we can do great things.

Mother Teresa 



\section{ACKNOWLEDGMENTS}

I would like to express my deepest appreciation to my supervisors, Alejandra and Cristina, for granting me the opportunity to improve my knowledge and education through this pre-doctoral contract. I would also like to thank my tutor, Isabel, for organizing and supporting my Thesis.

I would also like to extend my gratitude to my lab colleagues, Pilar, Rebeca, Carmen, Juani and Begoña, for supporting me in carrying out lab experiments and with data analysis.

I am grateful to Allan for letting me take part in plant and food research in Auckland, New Zealand. I also had great pleasure working with Ricardo, Magda and Lucimara in Piracicaba and Bento Gonçalves, Brazil. It was a great experience for me to work with other fruits and commercial persimmon varieties in other countries.

To my family, thank you for all your guidance and teaching over the years. You have supported me at every stage of my life and shaped me into the person that I am today.

Finally, I would like to thank the Instituto Nacional de Investigación y Tecnología Agraria (INIA) for the pre-doctoral grant and also the Instituto Valenciano de Investigaciones Agrarias (IVIA) for providing the equipment and materials needed to accomplish my Thesis. 



\section{ABSTRACT}

In the last two decades, persimmon production in Spain has increased exponentially and the cultivation area has expanded almost eight-fold. The current production of persimmon is focused on the cultivar 'Rojo Brillante', which is appreciated worldwide due to the high quality of the fruit. Nevertheless, centralized production of this single cultivar implies a major commercial limitation as its high volume of production is concentrated in a relative short harvesting period. Furthermore, it also implies a high phytosanitary risk.

In this context, this Thesis addresses two main objectives: 1) Optimization of pre- and postharvest technology in order to guarantee the quality of 'Rojo Brillante' persimmon after cold storage and transportation to overseas markets. 2) Evaluation of the behavior of foreign varieties of persimmon under Mediterranean conditions in order to extend the varietal range.

The first objective of this Thesis was tackled through the studies presented in Chapters I to V. The second objective was covered in Chapters VI and VII.

Chapter I dealt with the causes of internal browning disorder manifested after cold shipment of 'Rojo Brillante' persimmons to overseas markets. The temperature to which fruit is exposed immediately after $\mathrm{CO}_{2}$ deastringency treatment was identified as the main factor involved in this alteration. Our results showed that this disorder can be avoided by implementing an attemperation period of $24 \mathrm{~h}$ after the $\mathrm{CO}_{2}$ treatment, before transferring fruit to cold storage.

In Chapter II, the effectiveness of a recently patented deastringency treatment was evaluated. This novel treatment is based on applying a new wax containing ethanol and was assayed in 'Rojo Brillante' and 'Triumph' persimmons. The use of this new ethanol-based wax could be a potential alternative to the conventional $\mathrm{CO}_{2}$ deastringency treatment when the fruit are sent to distant overseas markets at low temperatures. Application of the new wax before cold storage led to loss of fruit astringency after 30 days at 0 ${ }^{\circ} \mathrm{C}$ while preserving fruit firmness and internal quality. 
The results of Chapter III demonstrated that two applications of gibberellic acid (GA) made it possible to delay the fruit maturity process on the tree more than with just a single application. The combination of GA and 1methylciclopropene (1-MCP) preserved the fruit quality better than with the application of 1-MCP alone during cold storage. Moreover, the fruit treated by multiple GA applications showed a slightly higher firmness after cold storage. However, a single GA application was also effective in preventing the manifestation of chilling injury $(\mathrm{Cl})$ in fruit.

Chapter IV demonstrated that in parallel to delaying maturity, the GA treatment also delayed calyx senescence, which meant that the fruit preserved a good appearance. The calyx lobe senescence during fruit ripening was linked to a decrease in all Chlorophyll Fluorescence Imaging (CFI) parameters (Fo, Fm, and $\mathrm{Fv} / \mathrm{Fm})$.

Chapter $\mathbf{V}$ addressed the optimization of storage conditions for organic persimmons. According to our results, fruit harvested with a firmness lower than $30 \mathrm{~N}$ must not be stored. Fruit harvested with a higher level of firmness could be stored for up to three weeks depending on the storage conditions, the moment of application of the $\mathrm{CO}_{2}$ deastringency treatment, and the stage of fruit maturity. The longest storage period ( 3 weeks) was achieved when fruit were harvested with a firmness of around $45 \mathrm{~N}$, submitted to $\mathrm{CO}_{2}$ treatment and then stored at $15^{\circ} \mathrm{C}$.

Finally, 14 foreign varieties grown under Mediterranean conditions were evaluated to identify early- and late-season varieties with potential to extend the harvesting period. This is presented in Chapters VI and VII. In general, all the evaluated varieties fulfilled the quality criteria to be commercialized in domestic and European markets. However, sensitivity to $\mathrm{Cl}$ was variety dependent and response to 1-MCP treatment was also observed to depend on the variety. 


\section{RESUMEN}

En las últimas dos décadas, la producción de caqui en España ha aumentado exponencialmente y la superficie de cultivo se ha multiplicado casi por ocho. En la actualidad, la producción de caqui está centralizada en el cultivar 'Rojo Brillante', que es mundialmente apreciado por la elevada calidad de sus frutos. Sin embargo, esta centralización supone una importante limitación comercial, ya que la producción se concentra en un período de cosecha relativamente corto y además implica un alto riesgo fitosanitario.

En este contexto, en la presente Tesis se abordan dos objetivos principales: 1) Optimización de la tecnología pre y postcosecha con el fin de garantizar la calidad del caqui 'Rojo Brillante' durante la frigoconservación y el transporte a mercados internacionales. 2) Evaluación del comportamiento bajo condiciones mediterráneas de variedades introducidas de otras regiones productoras con el fin de ampliar el rango varietal de caqui. El primer objetivo de esta Tesis se logró a través de los estudios presentados en los Capítulos I al V. El segundo objetivo se abordó en los Capítulos VI y VII.

En el Capítulo I se esclarecieron las causas del pardeamiento interno, que es una de las principales alteraciones que limita la comercialización del fruto en los envíos a los mercados internacionales. La temperatura a la que se expone la fruta inmediatamente tras la aplicación del tratamiento de desastringencia con altas concentraciones de $\mathrm{CO}_{2}$ se identificó como el principal factor implicado en esta alteración. Los resultados obtenidos mostraron que esta alteración se puede evitar mediante la implementación de un período de atemperado de $24 \mathrm{~h}$ después del tratamiento con $\mathrm{CO}_{2}$, antes de transferir la fruta a bajas temperaturas.

En el Capítulo II se evaluó la eficacia de un tratamiento de desastringencia recientemente patentado. El tratamiento basado en la aplicación de una nueva cera que contiene etanol en su formulación fue ensayado en caquis 'Rojo Brillante' y 'Triumph'. Los resultados mostraron que esta cera podría ser una alternativa al tratamiento convencional de desastringencia con altas concentraciones de $\mathrm{CO}_{2}$ cuando la fruta se envía a mercados lejanos a bajas temperaturas. La aplicación de la nueva cera antes de conservación en frío 
provocó la pérdida de astringencia de la fruta tras 30 días a $0{ }^{\circ} \mathrm{C}$, preservando al mismo tiempo la firmeza de la fruta y la calidad interna.

Los resultados del Capítulo III demostraron que la realización de dos aplicaciones de ácido giberélico (AG) en precosecha permite retrasar el proceso de maduración de la fruta en el árbol con respecto a una sola aplicación. La combinación de AG en precosecha y 1-metilciclopropeno (1$\mathrm{MCP}$ ) en postcosecha resultó en una mayor calidad del fruto durante la frigoconservación en comparación con la aplicación únicamente de 1-MCP. Además, la fruta tratada con múltiples aplicaciones de AG mostró una firmeza ligeramente mayor tras de conservación a baja temperatura; sin embargo, una sola aplicación de AG también previno la manifestación de daños por frío en la fruta.

En el Capítulo IV se demostró que, paralelamente al retraso de la maduración, el tratamiento con AG también retrasa la senescencia del cáliz, incrementando la calidad externa del fruto. La senescencia del cáliz durante la maduración del fruto se relacionó con una disminución de los parámetros de fluorescencia de clorofila (Fo, Fm y Fv/Fm).

En el Capítulo $\mathbf{V}$ se estudiaron las condiciones óptimas de almacenamiento del caqui producido bajo cultivo ecológico. Según los resultados obtenidos, no se deben almacenar los frutos cosechados con firmeza inferior a $30 \mathrm{~N}$. La calidad del fruto durante la conservación dependió de las condiciones de almacenamiento, momento de aplicación del tratamiento de deastringencia y estado de madurez inicial. Fruta cosechada con firmeza alrededor de $45 \mathrm{~N}$ y sometida al tratamiento de desastringencia antes del almacenamiento a $15^{\circ} \mathrm{C}$ pudo ser conservada con buena calidad por un periodo de hasta 3 semanas.

Por último, en los Capítulos VI y VII se abordó la evaluación bajo condiciones mediterráneas de 14 variedades de caquis no-astringentes procedentes de otros países. Se identificaron las variedades tempranas y tardías que pueden ser potencialmente interesantes para ampliar el período de cosecha en nuestra región. Los estudios postcosecha mostraron que todas las variedades estudiadas presentan una buena aptitud para ser comercializadas en los mercados nacionales y europeos. Sin embargo, la sensibilidad a los daños por 
frío que presentaron algunas de las variedades estudiadas podría limitar su comercialización a países de ultramar. Además, se observó que la respuesta al tratamiento con 1-MCP, para el control de los daños por frío, dependió en gran medida de la variedad. 



\section{RESUM}

En les últimes dues dècades, la producció de caqui a Espanya ha augmentat exponencialment i la superfície de cultiu s'ha multiplicat quasi per huit vegades. En l'actualitat, la producció de caqui està centralitzada en el la cultivar 'Rojo Brillante', que és mundialment apreciat per l'elevada qualitat dels seus fruits. Malgrat això, aquesta centralització suposa d'una banda una important limitació comercial, ja que la producció es concentra en un període de collita relativament curt i, d'altra banda implica un alt risc fitosanitari.

En aquest context, en la present Tesi s'aborden dos objectius principals: 1) Optimització de la tecnologia pre i postcollita amb la finalitat de garantir la qualitat del caqui 'Rojo brillante' durant la frigoconservació i el transport a mercats internacionals. 2) Avaluació del comportament de varietats introduïdes d'altres regions productores sota condicions mediterrànies amb la finalitat d'ampliar el rang varietal de caqui. El primer objectiu d'aquesta Tesi es va aconseguir a través dels estudis presentats en els Capítols I al V. El segon objectiu es va abordar en els Capítols VI i VII.

En el Capítol I es van esclarir les causes de I l'enfosquiment intern, que és una de les principals alteracions que limita la comercialització del fruit en els enviaments als mercats internacionals. La temperatura a la qual s'exposa la fruita immediatament després de l'aplicació del tractament de desastringència amb altes concentracions de $\mathrm{CO}_{2}$ es va identificar com el principal factor implicat en aquesta alteració. Els resultats obtinguts van mostrar que aquesta alteració es pot evitar mitjançant la implementació d'un període de temperat de $24 \mathrm{~h}$ després del tractament amb $\mathrm{CO}_{2}$, abans de transferir la fruita a baixes temperatures.

En el Capítol II es va avaluar l'eficàcia d'un tractament de desastringència recentment patentat. El tractament basat en l'aplicació d'una nova cera que conté etanol en la seua formulació va ser assajat en caquis 'Rojo Brillante' i 'Triumph'. Els resultats van mostrar que aquesta cera podria ser una alternativa al tractament convencional de desastringència amb altes concentracions de $\mathrm{CO}_{2}$ quan la fruita s'envia a mercats llunyans a baixes temperatures. L'aplicació de la nova cera abans de conservació en fred va 
provocar la pèrdua d'astringència de la fruita després de 30 dies a $0{ }^{\circ} \mathrm{C}$, preservant al mateix temps la fermesa de la fruita i la qualitat interna.

Els resultats del Capítol III van demostrar que l'aplicació de dos tractaments d'àcid giberèlic (AG) en precollita permet retardar el procés de maduració de la fruita en l'arbre respecte a una sola aplicació. La combinació de AG en precollita i 1-metilciclopropeno (1-MCP) en postcollita va incrementar la qualitat del fruit durant la frigoconservació en comparació amb l'aplicació únicament de 1-MCP. A més, la fruita tractada amb múltiples aplicacions de AG va mostrar una fermesa lleugerament major després de conservació a baixa temperatura; no obstant això, una sola aplicació de AG també va ser eficaç per a previndre la manifestació de danys per fred en la fruita. En el Capítol IV es va demostrar que, paral-lelament al retard de la maduració, el tractament amb AG també retarda la senescència del calze, incrementant la qualitat externa del fruit. La senescència del calze durant la maduració del fruit es va relacionar amb una disminució dels paràmetres de fluorescència de clorofil·la (Fo, Fm i $\mathrm{Fv} / \mathrm{Fm})$.

En el Capítol V es van estudiar les condicions òptimes d'emmagatzematge del caqui produït baix cultiu ecològic. D'acord amb els resultats obtinguts, no s'han d'emmagatzemar els fruits collits amb fermesa inferior a $30 \mathrm{~N}$. La conservació del fruit va dependre de les condicions d'emmagatzematge, moment d'aplicació del tractament de desastringència i estat de maduresa de la fruita. Així la fruita collida amb fermesa al voltant de $45 \mathrm{~N}$ i sotmesa al tractament de desastringència abans de l'emmagatzematge a $15^{\circ} \mathrm{C}$ va poder ser mantinguda per un període de fins a 3 setmanes.

Finalment, en els Capítols VI i VII es va abordar l'avaluació de 14 varietats de caquis no-astringents. Es van identificar les varietats primerenques i tardanes que poden ser potencialment interessants per a ampliar el període de collita a la nostra regió mediterrània. D'altra banda, els estudis postcollita van mostrar que totes les varietats estudiades presenten una bona aptitud per a ser comercialitzades en els mercats nacionals i europeus. No obstant això, la sensibilitat als danys per fred que van presentar algunes de les varietats estudiades podria limitar la seua comercialització a països d'ultramar. A més, 
es va observar que la resposta al tractament amb 1-MCP, per al control dels danys per fred, va dependre en gran manera de la varietat. 



\section{INDEX}

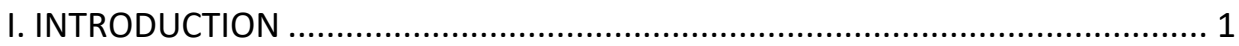

I.1. Origin, botany and morphology of persimmon...................................... 3

I.2. Worldwide production of persimmon .................................................... 6

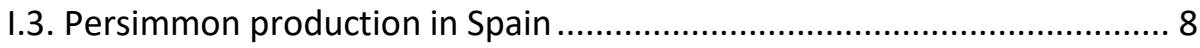

I.4. Current challenges in the postharvest of persimmon 'Rojo Brillante' .... 10

I.4.1 Treatments to remove astringency ............................................... 10

I.4.2 Cold storage and chilling injury ................................................... 14

I.5. Extending varietal range under Mediterranean agroclimatic conditions 16

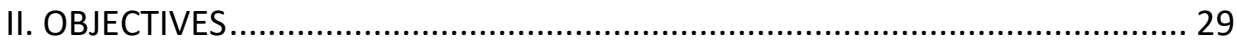

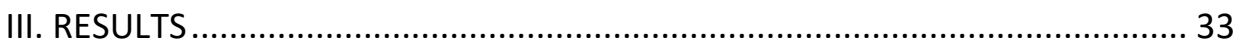

III.1. POSTHARVEST TECHNOLOGY TO GUARANTEE FRUIT QUALITY ON

ARRIVAL AT OVERSEAS MARKETS ….......................................................... 35

\section{CHAPTER I}

Effect of temperature during and immediately after $\mathrm{CO}_{2}$-deastringency

treatment on internal flesh browning after cold storage of persimmon fruit.. 37

Refrence: Siencia Horticulturae, 2020, 268, 109363.

https://doi.org/10.1016/j.scienta.2020.109363

\section{CHAPTER II}

Application of a new wax containing ethanol as a method to remove persimmon astringency during cold storage....

Refrence: Journal of Food Science and Technology, 2021.

https://doi.org/10.1007/s13197-021-05011-w 
III.2. PRE- AND POSTHARVEST METHODS TO GUARANTEE FRUIT QUALITY AFTER COLD STORAGE IN PACKING HOUSES.

\section{CHAPTER III}

Efecto de múltiples aplicaciones de Ácido Giberélico sobre la maduración y calidad postcosecha del caqui 'Rojo Brillante' 89

Refrence: Under Review: Levante Agrícola

\section{CHAPTER IV}

Chlorophyll fluorescence imaging as a tool to evaluate calyx senescence during ripening of persimmon fruit treated with gibberellic acid 107

Refrence: Under Review: Postharvest Biology and Technology

\section{CHAPTER V}

Effect of storage conditions on quality of persimmon produced under organic

conditions 135

Refrence: Acta Horticulturae, 1256, 2019, 195-202. ISHS, Proc. VI International Conference Postharvest Unlimited (Oct, 2017). Eds.: D. Valero et al. https://doi.org/10.17660/ActaHortic.2019.1256.27

\section{III.3. EVALUATION OF POSTHARVEST BEHAVIOR OF CULTIVARS INTRODUCED} FROM OTHER COUNTRIES UNDER MEDITERRANEAN CONDITIONS

\section{CHAPTER VI}

Harvest time and postharvest behavior of six Japanese non-astringent persimmon cultivars grown under Mediterranean conditions.

Refrence: HortScience, 2020, 55(11), 1766-1771.

https://doi.org/10.21273/HORTSCI15181-20

\section{CHAPTER VII}

Caracterización de variedades de caqui no astringentes del banco de germoplasma del IVIA.

Refrence: Agrícola vergel, 2020, N 428, 216-220

IV. GENERAL DISCUSSION 
V. GENERAL CONCLUSIONS ...

207 



\section{INTRODUCTION}





\section{I.1. Origin, botany and morphology of persimmon}

Persimmon trees belong to the family Ebenacea and genus Diospyros ('the fruit of the gods' in ancient Greek). This genus contains more than 2000 species, is native to Asia, and there are records of it being cultivated centuries before Christ (Martinez-Calvo et al., 2012). Most of the commercial fruit production is derived from Diospyros kaki L., which originated in China with production records from 3000 years ago.

Persimmon was introduced into Japan and Korea during the 7th and 14th centuries, respectively (Yakushiji \& Nakatsuka, 2007; Martinez-Calvo et al., 2012). It was then imported into Europe for the first time in 1760 and spread to the Mediterranean coast. Persimmon was introduced into North America in the mid-1800s and later into Australia and New Zealand. In South America, persimmon cultivation started in the late 19th century (Kluge \& Tessmer, 2018; Yesiloglu et al., 2018).

The introduction of persimmon in Spain dates to the end of 19th (Climent and Llácer, 2001), which could be for a strong relationship between the Spanish kingdom and Oriental countries during the colonization period. They were usually cultivated as isolated trees in rural buildings or field edges. The small commercial persimmon orchards began to be established in mid-20th with astringent native varieties that reflect the influence of natural (random seedlings and bud mutations) and human selection (cross-breeding) (Naval et al., 2010).

Botanically, persimmon fruit is a berry showing wide variation in size, weighing between 50 and over $500 \mathrm{~g}$, with a shape ranging from that of an acorn to flat, spherical or square with a skin color from light yellow-orange to dark orangered or blackish purple, depending on the cultivar. The flesh color varies from yellow-orange, and sometimes reddish, to reddish brown or bronze, and it is made up of a dense cell structure, which may have large almond-shaped seeds in the inner section of the carpels. Persimmon fruit have a relatively large, green, four-lobed calyx that surrounds the stem-end of the fruit and plays an important role in gas exchange, as there are no stomata or lenticels on the fruit surface, which is covered with a thin cuticle (Yonemori et al., 1996; PérezMunuera et al., 2009a; Woolf \& Ben-Arie, 2011). Moreover, from a commercial 
point of view, the state of the calyx is an important quality attribute. Fruit maturation is accompanied by calyx senescence and its darkening, which is associated with a loss of commercial quality.

An important feature of some persimmon varieties is their high soluble tannin content in the flesh, which is responsible for the sensation of astringency. Astringency is the dry feeling in the mouth caused when soluble tannins of the fruit bind to proteins in the saliva, preventing them from lubricating the mouth. Persimmon cultivars are classified into two general groups depending on the level of soluble tannins at harvest time: astringent and non-astringent (the latter are also called "sweet cultivars") (Yonemori et al., 2003). In both groups, there are varieties in which the soluble tannin content of the fruit is affected by pollination (pollination variant) and varieties whose fruits are not influenced by pollination (pollination constant). Therefore, persimmon fruits can be classified into four categories: 1) the Pollination Constant NonAstringent (PCNA) group, which is not astringent, with or without seeds, and the fruit can be eaten at harvest, when they are firm and crisp; 2) the Pollination Variant Non-Astringent (PVNA) group, which is not astringent at harvest if the persimmons have seeds, and the fruit remain astringent if they have not been pollinated; 3 ) the Pollination Constant Astringent (PCA) group, which is always astringent when the fruit are firm; 4) the Pollination Variant Astringent (PVA) group, which is also astringent if pollinated, and is not astringent around the seed, where the flesh is dark and streaked (Tetsumura et al., 2008). One cultivar belonging to each category is shown in figure 1. 


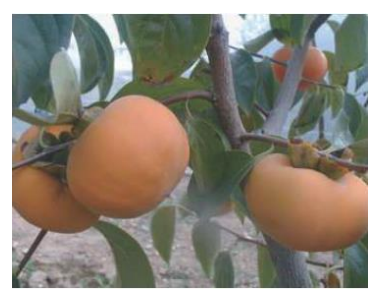

'O' Gosho' (PCNA)

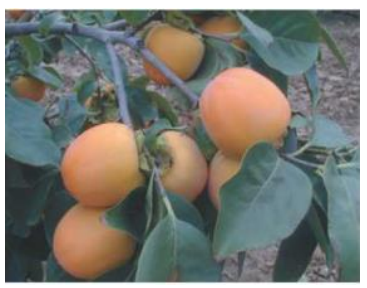

'Rojo Brillante' (PVA)

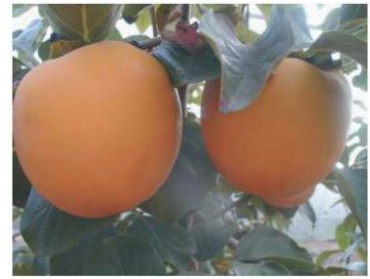

'Kaki Tipo' (PVNA)

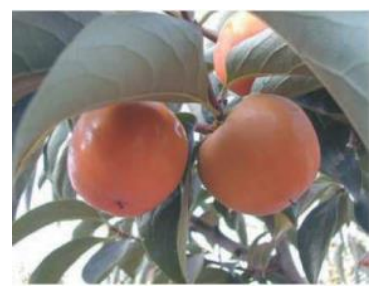

'Anheca' (PCA)

Fig. 1. Cultivars of persimmon from different categories.

Courtesy of Instituto Valenciano de Investigaciones Agrarias (IVIA)

The loss of astringency in PCNA varieties seems to be related to a combination of an early reduction of the accumulation of tannins, followed by a later insolubilization of them that remain in the flesh (Yonemori et al., 2003; Tessmer et al., 2016). However, in the other types, tannin accumulation continues until the late development stages of the fruit. In PVNA and PVA, seeds exude acetaldehyde, which causes the insolubilization of soluble tannins in the flesh. However, while the seeds of the PVNA group exude so much acetaldehyde that the fruit become non-astringent, those of PVA produce so little that only the pulp around the seed is not astringent. In the case of PCA cultivars, their seeds do not produce acetaldehyde, and thus they are always astringent regardless of the presence of seeds.

The fruit of the PCNA group can be eaten with a hard texture since their concentration of soluble tannins is low enough not to be sensory-detected at maturity stages in which the fruit flesh is firm. In contrast, fruit from the other groups have a high soluble tannins content at harvest when they are firm. They 
must therefore be submitted to postharvest deastringency treatments before being marketed, otherwise the fruit must be left on the tree until they over ripen and are eaten with a soft texture.

\section{I.2. Worldwide production of persimmon}

FAO statistical databases (2018) show worldwide production of persimmon to be around 4,711,458 tonnes and 951,234 ha of cultivated area, China being the biggest producer with $3,168,759$ tonnes (Table 1 ).

Table 1. Worldwide persimmon fruit production

\begin{tabular}{llll}
\hline Country & Production (Tonnes) & Area (ha) & Yield (kg/ha) \\
\hline Worldwide & $4,711,458$ & 951,234 & 4,952 \\
China & $3,168,759$ & 857,672 & 3,695 \\
Spain & 492,320 & 18,601 & 26,467 \\
Republic of Korea & 346,679 & 27,203 & 12,744 \\
Japan & 208,000 & 19,100 & 10,890 \\
Azerbaijan & 160,092 & 10,474 & 15,285 \\
Brazil & 156,935 & 8,133 & 19,296 \\
Uzbekistan & 71,214 & 4,262 & 16,710 \\
Italy & 47,615 & 2,468 & 19,293 \\
Israel & 28,000 & 1,049 & 26,692 \\
Iran & 22,474 & 1,523 & 14,760 \\
\hline
\end{tabular}

Source: FAOSTAT (2018)

In China, most of the persimmon varieties are PCA with some exceptions, like 'Luo Tian Shi', which is PCNA (Yamada et al., 1995; Yamada \& Sato, 2013). Recently, some Japanese PCNA cultivars like 'Jiro', 'Youhou', 'Taishu' and 'Fuyu' are also becoming popular in China. In general, its production is based on a wide range of persimmon varieties with low yields, which are used for both fresh consumption and the food industry, especially as a dried fruit.

Over the last few years, Spain has become the world's second most important persimmon producer. Persimmon cultivation is currently based on the 'Rojo Brillante' cultivar (PVA), produced mainly in Valencia (eastern Spain), and the 'Triumph' cultivar (PVA), which is cultivated mainly in Andalusia (southern Spain). The Spanish production is mainly destined for exportation markets where there is a demand for persimmons as fresh fruit with a firm texture. 
The third and fourth countries in persimmon production are the Republic of Korea and Japan with a production of 346,479 and 208,000 tonnes, respectively. In the Republic of Korea, the non-astringent cultivar 'Fuyu' is the primary cultivar, which accounts for almost $82 \%$ of the total production, followed by 'Jiro' with $9.8 \%$ (Choi et al., 2014). In Japan, 'Fuyu' and the PVA cultivars 'Hiratanenashi' and 'Tonewase' are the three most important cultivars. Approximately $57 \%$ of the persimmon cultivated area is dedicated to these cultivars (Kono \& Sato., 2016). In these two countries, the Republic of Korea and Japan, most persimmon production is consumed as dried fruit and is used in various types of cuisine and confectionery.

Persimmon production in Azerbaijan, Brazil and Uzbekistan is 160,092 tonnes, 156,935 tonnes and 71,214 tonnes, respectively. Azerbaijan and Uzbekistan focus on local astringent varieties. In Brazil, the most cultivated varieties of persimmon are 'Rama forte' and 'Giombo', which belong to the PVA group. 'Taubate' (PCA) and cultivar 'Fuyu' are also cultivated in this country (Neuwald et al., 2009; Tessmer et al., 2014).

In Italy, almost $90 \%$ of the total production is based on 'Kaki Tipo' (PVNA). The rest of the varieties are 'Vainiglia', 'Mercatelli', 'Moro' (PVNA), and PCNA cultivars like 'Gosho', 'Jiro' and cultivar 'Fuyu' (Bellini \& Giordani, 2003). Moreover, the introduction of 'Rojo Brillante' has been the main innovation in the Italian persimmon production in recent years (Giordani, 2002; Bellini \& Giordani, 2005).

Nowadays, persimmon production in Israel has reached 28,000 tonnes, in which the cultivar 'Triumph' accounts for 90\% of the total persimmon fruit marketed under the 'Sharon' or 'Sharoni' brands (Llácer \& Badenes, 2002).

Persimmon production in Iran is about 22,474 tonnes and most of the cultivars are astringent, which are commonly commercialized as over-ripened soft fruit in domestic markets (Shahkoomahally \& Ramezanian, 2013; Bagheri et al., 2015). 


\section{I.3. Persimmon production in Spain}

In Spain, persimmon production has increased exponentially over the last 20 years, and the cultivation area has expanded almost eight-fold, from about 2,253 ha in 2002 to over 18,000 ha in 2019 (Fig. 2). As a result, Spain is now the second most important persimmon producing country in the world. At present, cultivation is concentrated in the Valencia and Andalusia regions. In Valencia cultivation is based on 'Rojo Brillante' with a production of around 429,000 tonnes. In Andalusia, where production was previously based on the 'Triumph' variety, the introduction of 'Rojo Brillante' in recent years has resulted in a considerable increase in production and the current persimmon production consists of 50,000 tonnes of 'Rojo Brillante' and 10,000 tonnes of the 'Triumph' (Perucho, 2018).

The 'Rojo Brillante' variety originated naturally from a spontaneous bud mutation of the variety 'Cristalino' in the 1940s, which occurred in the 'Ribera de Xúquer' region of the Valencian Community (Perucho, 2015). The 'Rojo Brillante' variety offers a number of good features like large fruit size, hardness, resistance on the tree, and good organoleptic and morphologic properties.

Traditionally, the fruit of this variety were consumed with a soft texture after the natural loss of astringency during the over-ripening of the fruit. However, the introduction of postharvest techniques based on exposing the fruit to high $\mathrm{CO}_{2}$ concentrations to eliminate astringency in the late 1990s made it possible to obtain a fruit without astringency while preserving a firm texture. The introduction of this postharvest treatment has been one of the main causes of the expansion of persimmon production in Spain in recent years. This growth was supported by the creation of Council Regulator of the Denomination of Origin (CRDO) 'Kaki Ribera del Xúquer' in 1997, which guarantees the quality of persimmon 'Rojo Brillante' and has been responsible for promoting this cultivar in fruit markets around the world. 

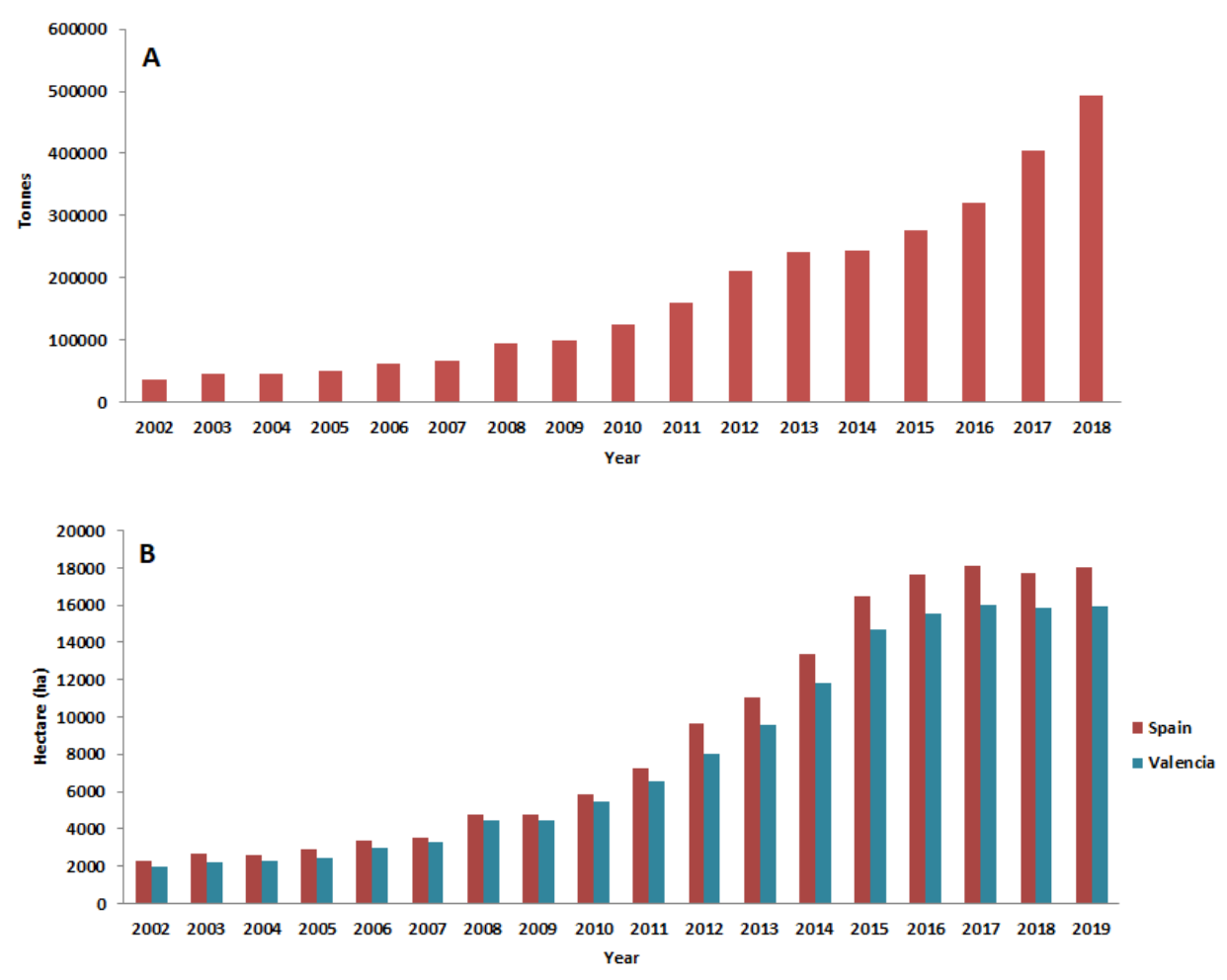

Fig. 2. Evolution of Spanish persimmon fruit production in tonnes of fruit $(A)$ and its cultivation area in Spain and the Valencian community (B). Source: FAOSTAT (2018); ESYRCE (2019)

The optimization of the postharvest treatment and an important commercial effort has led to the present situation, in which almost $90 \%$ of the total amount of persimmon produced in Spain is destined for exportation, especially to European Union countries like Germany, France, and United Kingdom (Perucho, 2018) as well as to overseas countries like the United States and China. To ensure that the fruit delivered to the final destinations is of high quality, it has been necessary to introduce postharvest technologies capable of preserving fruit quality during transport and subsequent marketing. 
Although the variety 'Rojo Brillante' caused a revolution in persimmon production in Spain, persimmon cultivation cannot be based exclusively on a single variety. This need to diversify is not only due to limitations caused by its short commercial season (between mid-October and December) but also to the high phytosanitary risk that growing a single variety entails. This risk became evident during the seasons 2008-2010 when the fungus Mycosphaerella Nawae led to a significant reduction in persimmon production due to the high sensitivity of 'Rojo Brillante' (Berbegal et al., 2011). This is why, at present, one of the principal challenges for the persimmon producing sector is to widen the varietal range, mainly with early and late cultivars that will allow the persimmon season to be extended and to satisfy the market demand for new products, with the consequent economic benefits. Moreover, the introduction of non-astringent varieties that can be commercialized directly after harvest without any of the complications resulting from handling and the economic cost of using deastringency treatment is also of special interest for persimmon producers.

\section{I.4. Current challenges in the postharvest of persimmon 'Rojo Brillante'}

After fruit harvesting, persimmons are sent to packing houses where, depending on the market destination, fruit are submitted to different postharvest procedures. The main processes that are carried out in the packing houses are polishing, sorting, and packing. 'Rojo Brillante' persimmons are also submitted to deastringency treatments to remove astringency before consumption. Moreover, fruit storage is a common practice to be able to supply markets in line with demands, and different postharvest technologies are used to preserve fruit quality according to storage duration and temperature (Besada \& Salvador, 2018).

\subsubsection{Treatments to remove astringency}

One of the traditional postharvest methods to remove fruit astringency is to use ethylene $\left(10 \mathrm{ppm}\right.$ at $20^{\circ} \mathrm{C}$ ) to accelerate the maturation process (Park al., 2003). This treatment causes rapid ripening and loss of firmness, leading to postharvest handling limitations and reducing the fruit's postharvest life. 
Therefore, fruit that are over-ripened are mainly commercialized in local markets.

There are other methods to eliminate astringency while maintaining the fruit firmness. These methods are based on keeping the fruit under hypoxia conditions, which enhances anaerobic respiration. The two most extensively tested methods consist in submitting the fruit to ethanol vapor and high $\mathrm{CO}_{2}$ concentrations (Besada \& Salvador, 2018).

Several reports have shown that the deastringency rate under anaerobic conditions is related to acetaldehyde accumulating in the flesh of the persimmon fruit (Matsuo \& Ito, 1978; Sugiura \& Tomana, 1983; Pesis et al., 1988; Taira et al., 1989) (Fig. 3). Acetaldehyde accumulated in the flesh under anaerobic conditions causes polymerization in soluble tannins and forms insoluble compounds, which result in non-astringency in fruit. (Fig. 4) (Matsuo \& Ito, 1982; Taira et al., 1997).

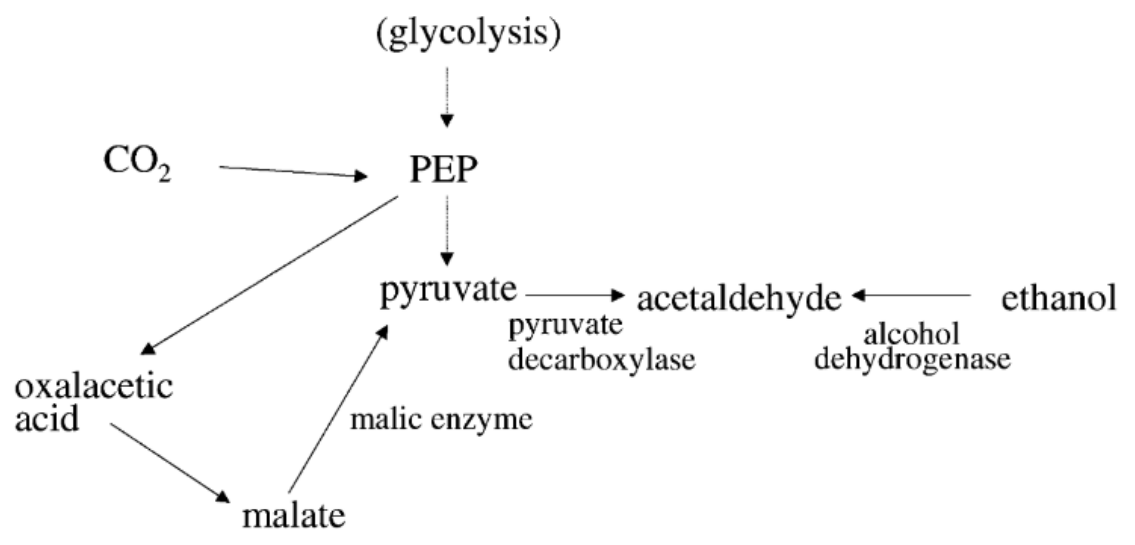

Fig. 3. Metabolic pathways for the production of acetaldehyde in persimmon fruit. Source: Yamada et al. (2002). 


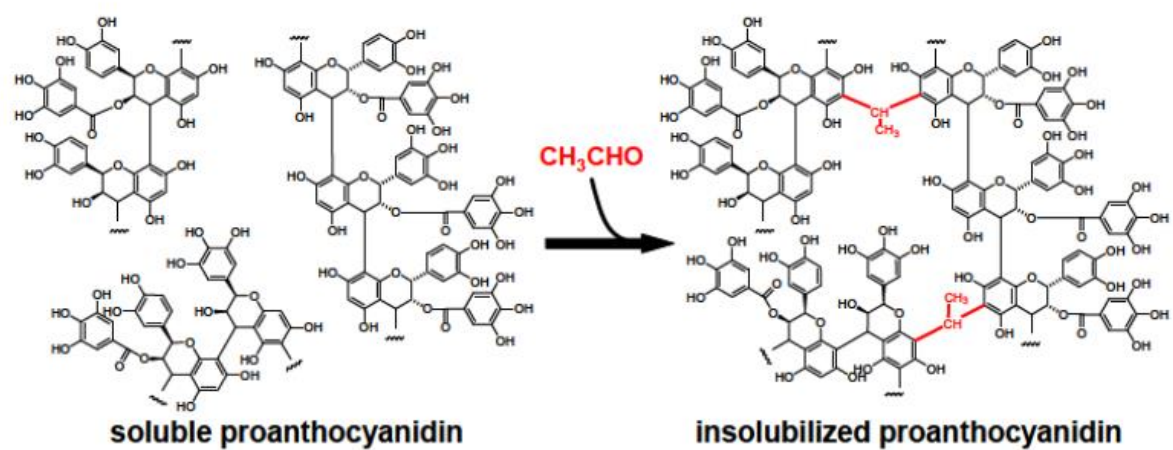

Fig. 4. Insolubilization of proanthocyanidin in persimmon fruits. Source: Tanaka et al. (2010).

Among the treatments based on keeping the fruit under anaerobiotic conditions, the $\mathrm{CO}_{2}$ treatment consisting in enclosing persimmons in chambers with a high concentration of $\mathrm{CO}_{2}$ stands out for its effectiveness and it has been commercially adopted to supply fruit with a hard texture (Arnal \& Del Río, 2003). In 'Rojo Brillante', the insolubilization of tannins caused by the acetaldehyde generated during the $\mathrm{CO}_{2}$ treatment has been visualized at the microstructural level as insoluble materials inside the vacuoles of some tannic cells in the flesh, which were filled with soluble materials prior to the treatment (Salvador et al., 2007).

The main factors that affect the efficiency of the $\mathrm{CO}_{2}$ treatment are temperature, $\mathrm{CO}_{2}$ concentration, and treatment duration, as well as the fruit maturity stage (Besada \& Salvador, 2011). The process of astringency removal by $\mathrm{CO}_{2}$ consists of two phases: an induction phase in which persimmon must be held for a minimum duration at high $\mathrm{CO}_{2}$ concentration and a series of reactions take place, and a second phase during which the astringency is reduced but the existence of carbon dioxide is not required (Gazit \& Adato, 1972). These two phases depend on temperature (Matsuo \& Ito, 1977). Currently, the standard condition to apply the $\mathrm{CO}_{2}$ deastringency treatment for 'Rojo Brillante' is exposure of the fruit to $95 \%-98 \% \mathrm{CO}_{2}$ at $20{ }^{\circ} \mathrm{C}$ and $90 \% \mathrm{RH}$ for 
24 h (Besada \& Salvador, 2018). Under commercial conditions, however, the $\mathrm{CO}_{2}$ treatment may be applied at room temperature due to lack of temperature control in the chambers. At the end of the season, the ambient temperature may be decreased and reach as low as $12{ }^{\circ} \mathrm{C}$, which is below the optimum established temperature of $20^{\circ} \mathrm{C}$. In these cases, the deastringency treatment has to be prolonged in order to achieve complete astringency removal. However, it has been reported that if the fruit are over-exposed to $\mathrm{CO}_{2}$, it may result in internal browning disorders (Besada et al., 2018). Therefore, the recommendation is to apply the $\mathrm{CO}_{2}$ deastringency treatment for the minimum amount of time necessary to ensure astringency removal.

This recommendation is based on the fact that applying the $\mathrm{CO}_{2}$ deastringency treatment has been shown to induce oxidative burst in fruit and lead to changes in their redox state (Novillo et al., 2014). Considering that the stress triggered by $\mathrm{CO}_{2}$ treatment could cause alterations in fruit, it is necessary to find alternative treatments for removing astringency.

As shown in Figure 2, acetaldehyde is generated in situ by decarboxylation of pyruvic acid and the oxidation of exogenous and endogenous ethanol. Therefore, the acetaldehyde needed to remove astringency can be achieved by exposing the fruit to hypoxia conditions or by submitting it to exogenous ethanol.

In line with this, the combination of high levels of $\mathrm{CO}_{2}$ and ethanol has also been studied to accelerate deastringency treatment and preserve fruit quality (Novillo et al., 2015). It has been demonstrated that this combination could be a good alternative in those cases in which $\mathrm{CO}_{2}$ application has to be prolonged in order to ensure complete astringency removal.

Moreover, ethanol by itself, has been demonstrated to be an effective deastringency treatment. Thus, application of $25 \%-35 \%$ ethanol vapor has been widely assayed in different persimmon cultivars. In this case, the acetaldehyde needed to insolubilize soluble tannins is generated from ethanol by the alcohol dehydrogenase enzyme (Taira et al., 1989, 1992a; Yamada et al., 2002). The cultivar and harvest maturity are the factors that influence the removal of astringency with application of ethanol. The fastest drop in soluble tannins content occurs in fruit at a lesser stage of ripening and with a higher 
ethanol concentration. As in younger fruit, ethanol conversion is more active, astringency removal is accomplished more easily compared to more mature fruit, and it is taken into fruit during the treatment as acetaldehyde in the flesh (Taira et al., 1992b).

\subsubsection{Cold storage and chilling injury}

The cold storage of 'Rojo Brillante' is a common practice to be able to supply markets according to demand and prolong the commercial period, especially at the end of the season. Moreover, cold storage helps to preserve fruit quality during prolonged transportation and fruit shipment to overseas markets is habitually carried out at low temperatures due to quarantine requirements.

However, different alterations have been associated with the cold storage of persimmon fruit and have been addressed in numerous studies. The alterations which occurred in fruit associated with cold storage are named 'chilling injury' (Cl) symptoms. Some varieties can be stored for two months at $0{ }^{\circ} \mathrm{C}$ without any loss of quality (Testoni, 2002), while other varieties are more sensitive and prone to develop $\mathrm{Cl}$ symptoms at low temperatures (Collins \& Tisdell, 1995; Arnal \& Del Río, 2004). Cultivars like 'Hachiya' and 'Triumph' have low sensitivity to $\mathrm{Cl}$, whereas cultivars such as 'Fuyu' and 'Rojo Brillante' are highly susceptible to this disorder (Collins \& Tisdell, 1995; Woolf et al., 1997; Arnal \& Del Rio, 2004; Zhang et al., 2010).

The symptoms of $\mathrm{Cl}$ depend on the cultivar; yet, loss of firmness is reported as the main manifestation of $\mathrm{Cl}$ in sensitive varieties (Macrae, 1987a; PérezMunuera et al., 2009b). These disorders are more severe after transferring fruit from low to shelf-life temperatures, although during prolonged storage, the symptoms of $\mathrm{Cl}$ can eventually manifest during the cold storage period (Arnal \& Del Río, 2004).

In 'Rojo Brillante', the main symptoms of $\mathrm{Cl}$ are loss of firmness, compacted flesh zones, and internal browning (Arnal \& Del Rio, 2004; Salvador et al., 2005). In this variety, the development of $\mathrm{Cl}$ symptoms depends not only on the storage temperature and duration but also on the maturity stage at harvest. The 'Rojo Brillante' fruit show higher incidences of $\mathrm{Cl}$ when they are picked in early stages of maturity (Salvador et al., 2005, 2006). A 
microstructural study showed that the drastic flesh softening, as a symptom of $\mathrm{Cl}$, is related to degradation of cell wall material and reduction in intercellular connection (Pérez-Munuera et al., 2009b).

Ethylene plays an important role in the manifestation of $\mathrm{Cl}$, where exogenous ethylene exposure intensifies $\mathrm{Cl}$ (MacRae, 1987b; Park \& Lee, 2005; Besada et al., 2010). The respiration rate and ethylene production are higher in chillinjured fruit when they are removed from cold storage than in sound fruit (MacRae, 1987a; Kader, 2002). In line with this, a postharvest treatment applying 1-MCP (an inhibitor of the ethylene action) before cold storage has been reported to be effective in reducing the symptoms of $\mathrm{Cl}$ in different persimmon cultivars. The effect of 1-MCP to alleviate the disorders associated with low temperature has been found in different astringent cultivars like 'Rojo Brillante' (Besada et al., 2014), 'Saijo' and 'Tonewase' (Harima et al., 2003), 'Hiratanenashi' (Kubo et al., 2003) and 'Triumph' (Tsviling et al., 2003), as well as many non-astringent cultivars such as 'Rendaiji' (Ortiz et al., 2005), 'Nathanzy' (Ramin, 2008), 'Matsumotowase-Fuyu' (Niikawa et al., 2005), 'Qiandaowuhe' (Luo, 2007), 'Bianhua' (Luo, 2004) and 'Fuyu' (Fang et al., 2009), among others. The efficacy of 1-MCP depends on the cultivar, the harvest maturity, and the storage conditions (Huber, 2008; Watkins, 2008). Moreover, its effectiveness also depends on the concentration, temperature, and duration of treatment (Blankenship \& Dole, 2003). The concentration of $500 \mathrm{~nL} \mathrm{~L}^{-1}$ of 1-MCP has been shown to delay flesh softening in persimmon 'Rojo Brillante' during cold storage, which is related to the preservation of cell wall integrity, decrease in membrane permeability, and higher firmness of fruit at shelf-life temperature (Pérez-Munuera et al., 2009b).

Furthermore, it has been reported that the storability of 'Rojo Brillante' treated with 1-MCP improves when a preharvest treatment with gibberellic acid (GA) is applied (Besada et al., 2008). GA is usually applied for 'Rojo Brillante' when the fruit breaks color in order to delay fruit maturation, and consequently extend the fruit harvest season. This effect of GA has also been reported in other persimmon cultivars such as 'Triumph', 'Fuyu' and 'Hiratanenashi' (Ben Arie et al., 1996; Lee et al., 1997; Agustí et al., 2003). Besada et al. (2008) reported the benefits of a single application of GA on fruit 
maturity delay and quality preservation during storage. However, nowadays, GA is being applied up to three times in persimmon orchards, but the effect of multiple applications of GA on cold storage of the fruit has been not described.

In postharvest handling of 'Rojo Brillante' persimmon, it is recommended that deastringency treatment should be carried out after storing the fruit at low temperatures, since it has been reported that a high $\mathrm{CO}_{2}$ concentration, besides insolubilizing soluble tannins, brings about a degradation of cell membranes (Salvador et al., 2007) that may aggravate fruit softening during cold storage. Nevertheless, in some marketing scenarios, the deastringency treatment is necessarily applied before submitting the fruit to low temperature storage. This is the case of fruit shipped to distant overseas countries under cold storage conditions. However, in shipments carried out under these conditions, internal browning has been observed, resulting in a loss of quality. This disorder cannot be associated with $\mathrm{Cl}$ because the fruit are treated with 1MCP. Up to now, the causes of this disorder and the potential solutions to control it are unknown.

Another challenge that must be solved is the storage of persimmon 'Rojo Brillante' cultivated under organic conditions, a tendency that has increased in recent years. 1-MCP treatment, which is usually applied in conventional production, is not allowed for organic production. Therefore, the storage of organic persimmon is limited by its sensitivity to low temperatures. It is thus necessary to find other solutions to prolong storage while preserving fruit quality.

\section{I.5. Extending varietal range under Mediterranean agroclimatic conditions}

As mentioned before, one of the main challenges facing the persimmon producing sectors is to introduce new varieties to broaden the varietal range. The focus is on introducing early and late, mainly non-astringent (PCNA), varieties in order to extend the persimmon commercialization period and facilitate postharvest handling.

Consequently, the Instituto Valenciano de Investigaciones Agrarias (IVIA, Valencia) in collaboration with the Cooperativa Agricola Nuestra Señora de 
L'Oreto. V. (CANSO, I'Alcúdia) through an agreement signed in 2002 which is still in force, started a persimmon breeding program to obtain new cultivars through conventional and biotechnological genetic techniques. Besides, within this program framework, new varieties from other persimmon producer countries have been introduced into the IVIA germplasm bank. To this end, IVIA is collaborating with germplasm programs hosted in other countries, which allows the introduction of foreign varieties without any phytosanitary risk.

Evaluations performed in the IVIA breeding program are focused on determining the agronomic behavior of the foreign varieties with potential interest under our agroclimatic conditions. However, it is necessary to include the postharvest behavior as a selection criterion, since the commercial success of a new variety depends heavily on its postharvest response. The postharvest behavior of a new variety mainly depends on genetic factors but may also be affected by agronomic conditions. Therefore, postharvest studies are required to establish the optimal harvesting moment, evaluate the response to habitually applied postharvest technologies such as $1-\mathrm{MCP}, \mathrm{CO}_{2}$, etc., and optimize these technologies if necessary.

\section{REFERENCES}

Agustí, M., Juan, M., Yagüe, B, Mesejo, C., Martínez-Fuentes, A., \& Almela, V. (2003). Tratamientos para retrasar la maduración del fruto del caqui (Dyospiros kaki L.). CV Agraria. 24, 27-33.

Arnal, L., \& Del Río, M. A. (2003). Removing Astringency by Carbon Dioxideand Nitrogen-Enriched Atmospheres in Persimmon Fruit cv. "RojoBrillante". Journal of Food Science. 68(4), 1516-1518. https://doi.org/10.1111/j.13652621.2003.tb09676.x

Arnal L., \& Del Rio M.A. (2004). Effect of cold storage and removal astringency on quality of persimmon fruit (Diospyros kaki, L.) cv. Rojo Brillante. Food Science and Technology International. 10 (3), 179-185. https://doi.org/10.1177/1082013204044824 
Bagheri, M., Esna-Ashari, M., \& Ershadi, A. (2015). Effect of postharvest calcium chloride treatment on the storage life and quality of persimmon fruits (Diospyros kaki Thunb.) cv. "Karaj". International Journal of Horticultural Science and Technology. 2, 15-26. https://doi.org/10.22059/IJHST.2015.54260

Bellini, E., \& Giordani, E. (2003). Germplasm conservation of persimmon in Europe. Acta Horticulturae. 601, 37-46. https://doi.org/10.17660/ActaHortic.2003.601.4

Bellini, E. \& Giordani, E. (2005). Germplasm and breeding of persimmon in Europe. Acta Horticulturae. 65-76. https://doi.org/10.17660/ActaHortic.2005.685.6

Ben-Arie, R., Saks, Y., \& Sonego, L. (1996). Cell wall metabolism in gibberellintreated persimmon fruits. Plant Growth Regulation. 19, 25-33. https://doi.org/10.1007/BF00024399

Berbegal, M., Armengol, J., \& García-Jiménez, J. (2011). Evaluation of fungicides to control circular leaf spot of persimmon caused by Mycosphaerellanawae. Crop Protection. 30, 1461-1468. https://doi.org/10.1016/j.cropro.2011.05.017

Besada, C., Arnal, L., \& Salvador, A. (2008). Improving storability of persimmon cv. Rojo Brillante by combined use of preharvest and postharvest treatments. Postharvest Biology and Technology. 50, 169-175. https://doi.org/10.1016/j.postharvbio.2008.05.013

Besada, C., Jackman, R. C., Olsson, S., \& Woolf, A. B. (2010). Response of 'Fuyu' persimmons to ethylene exposure before and during storage. Postharvest Biology and Technology. 57(2), 124-131. https://doi.org/10.1016/j. postharvbio.2010.03.002

Besada, C., Novillo, P., Navarro, P., \& Salvador, A. (2014). Effect of a low oxygen atmosphere combined with 1-MCP pretreatment on preserving the quality of 'Rojo Brillante' and 'Triumph' persimmon during cold storage. Scientia Horticulturae. 179, 51-58 
Besada, C., Novillo, P., Navarro, P. \& Salvador, A. (2018). Causes of flesh browning in persimmon-a review. Acta Horticulturae. 1195, 203-210. https://doi.org/10.17660/ActaHortic.2018.1195.32

Besada, C., \& Salvador, A. (2011). Postharvest Handling of Persimmon Fruit.In: Awaad, A. S., Kaushik, G., Govil, J. N., (Eds.). Mechanism and Action of Phytoconstituents. Recent Progress in Medical Plants. pp. 111-137.

Besada, C. \& Salvador, A. (2018). Postharvest biology and technology of persimmon. In: S. Mir, M. Shah, and M. Mir (eds.). Postharvest biology and technology of temperate fruits. Springer, Cham. pp. 371-393. https://doi.org/10.1007/978-3-319-76843-4_16

Blankenship, S. M., \& Dole, J. M. (2003). 1-Methylcyclopropene: a review. Postharvest Biology and Technology. 28(1), 1-25. https://doi.org/10.1016/S0925-5214(02)00246-6

Choi, ST., Park, DS., Son, JY., Kim, ES., Shin, HY., \& Kang, SM. (2014). Seasonal growth and characteristics of fruits developed from delayed flowers of 'Fuyu' persimmon. Scientia Horticulturae. 177, 108-111. https://doi.org/10.1016/j.scienta.2014.07.043

Climent, C., \& Llácer, G. (2001). Caqui. In: F. Nuez and G. Llácer (eds.). La Horticultura Española. Sociedad Española de Ciencias Hortícolas, Madrid.

Collins, R.J., \& Tisdell, J.S. (1995). The influence of storage time and temperature on chilling injury in Fuyu and Suruga persimmon (Diospyros kaki L.) grown in subtropical Australia. Postharvest Biology and Technology. 6, 149-157. https://doi.org/10.1016/0925-5214(94)00046-U

ESYRCE (2019). Encuesta sobre Superficies y Rendimientos. Ministerio de Agricultura, Alimentación y Medio Ambiente. Retrieved from http://www.magrama.gob.es/es/estadistica/temas/estadisticasagrarias/ agricultura/esyrce/.

Fang, H., ShuShang, M., JiShu, Z., QingMei, H., Gang, Z., \& ChunLin, W. (2009). Effects of 1-methylcyclopropene on postharvest physiology and cell 
ultrastructure of pollination-constant and non-astringent persimmon during storage. Acta Horticulturae Sinica. 36(4), 487-492.

FAOSTAT. (2018). Food and Agriculture Organization Corporate Statistical Database. Retrieved from http://faostat.fao.org/site/339/default.aspx.

Gazit, S., \& Adato, I. (1972). Effect of carbon dioxide atmosphere on the course of astringency disappearance of persimmon (Diospyros kaki Linn.) fruits. Journal of Food Science. 37(6), 815-817.

Giordani, E. (2002) Varietal assortment of persimmon in the countries of the Mediterranean area and genetic improvement. Options Mediterraneennes, Serie-A. Seminaires Mediterraneens. 51, 23-37.

Harima, S., Nakano, R., Yamauchi, S., Kitano, Y., Yamamoto, Y., Inaba, A., \& Kubo, Y. (2003). Extending shelf-life of astringent persimmon (Diospyros kaki Thunb.) fruit by 1-MCP. Postharvest Biology and Technology. 29(3), 319-324. https://doi.org/10.1016/S0925-5214(03)00058-9

Huber, D.J. (2008). Suppression of ethylene responses through application of 1methylcyclopropene: a powerful tool for elucidating ripening and senescence mechanisms in climacteric and nonclimacteric fruits and vegetables.

Hortscience.

43 ,

106-111. https://doi.org/10.21273/HORTSCI.43.1.106

Kader, A. A. (2002). Postharvest Technology of Horticultural Crops. Oakland, CA: UC ANR Publications.

Kluge, R.A., \& Tessmer, M.A. (2018). Caqui-Diospyros kaki. Exotic Fruits. 113119. https://doi.org/10.1016/B978-0-12-803138-4.00016-2

Kono, A., \& Sato S. (2016). Current status of persimmon production in Japan. VI International Symposium on Persimmon. pp. 13

Kubo, Y., Nakano, R., \& Inaba, A. (2003). Cloning of genes encoding cell wall modifying enzymes and their expression in persimmon fruit. Acta 
Horticulturae.

601(1),

49-55.

https://doi.org/10.17660/ActaHortic.2003.601.5

Lee, Y. M., Jang, S. J., \& Lee, Y. J. (1997). Effect of preharvest application of MGC-140 and GA3 on the storability of 'Fuyu' persimmon (Diospyros kaki L.). Journal of the Korean Society for Horticultural Science (Korea Republic). 38(2), 157-161.

Llacer, G., \& Badenes, M.L. (2002). Persimmon production and market. First Mediterranean Symposium on Persimmon. Options Mediterraneennes, Serie-A. Seminaires-Mediterraneens. 51, 9-22.

Luo, Z. (2004). Effect of 1-methylcyclopropene on persimmon fruit ripening and pectin metabolism. Journal of Fruit Science. 21(3), 229-232.

Luo, Z. (2007). Effect of 1-methylcyclopropene on ripening of postharvest persimmon (Diospyros kaki L.) fruit. LWT-Food Science and Technology. 40(2), 285-291. https://doi.org/10.1016/j.Iwt.2005.10.010

MacRae, E. (1987a). Development of chilling injury in New Zealand grown 'Fuyu'persimmon during storage. New Zealand Journal of Experimental Agriculture.

15(3),

333-344.

https://doi.org/10.1080/03015521.1987.10425579

MacRae, E. A. (1987b). Storage and shelf life of Fuyu and Flat Fuyu persimmon in New Zealand 1984-1986. Division of Horticulture and Processing. DSIR, Postharvest. Postharvest Bulletin. 335.

Martínez-Calvo, J., Badenes, M.L., \& Llácer, G. (2012). Descripción de nuevas variedades de caqui (Diospyros kaki Thunb.) del banco de germoplasma del IVIA. Monografías INIA: Série Agrícola, Valencia. 28, 1-19.

Matsuo, T., \& Ito, S. (1977). On mechanisms of removing astringency in persimmon fruits by carbon dioxide treatment I. Some properties of the two processes in the deastringency. Plant and Cell Physiology. 18(1), 1725. https://doi.org/10.1093/oxfordjournals.pcp.a075409 
Matsuo, T., \& Ito, S. (1978). The chemical structure of kaki-tannin from immature fruit of the persimmon (Diospyros kaki L.). Agricultural and Biological Chemistry. 42(9), 1637-1643. https://doi.org/10.1080/00021369.1978.10863225

Matsuo, T., \& Ito, S. (1982). A model experiment for de-astringency of persimmon fruit with high carbon dioxide: in vitro gelation of kaki-tannin by reacting with acetaldehyde. Journal of Agricultural and Biological Chemistry.

46 ,

683-689. https://doi.org/10.1080/00021369.1982.10865131

Naval, M. M., Zuriaga, E., Pecchioli, S., Llácer, G., Giordani, E., \& Badenes, M. (2010). Analysis of genetic diversity among persimmon cultivars using microsatellite markers. Tree Genetics \& Genomes, 6(5), 677-687. https://doi.org/10.1007/s11295-010-0283-0

Neuwald, D., Sestari, I., \& Saquet A. (2009). Persimmon production and commercialization in Brazil: An overview. Acta Horticulturae. 833, 51-56. https://doi.org/10.17660/ActaHortic.2009.833.7

Niikawa, T., Inari, T., Ozeki, T., \& Mitsui, B. (2005). Effects of 1methylcyclopropene on flesh firmness during storage of pollinationconstant and non-astringent cultivars of Japanese persimmon. Journal of the Japanese Society for Food Science and Technology. 52(2), 68-73.

Novillo, P., Gil, R., Besada, C., \& Salvador, A. (2015). Astringency removal of 'RojoBrillante' persimmon by combining $\mathrm{CO}_{2}$ and ethanol application. Acta Horticulturae. 1079 , 599-604. https://doi.org/10.17660/ActaHortic.2015.1079.81

Novillo, P., Salvador, A., Llorca, E., Hernando, I., \& Besada, C. (2014). Effect of $\mathrm{CO}_{2}$ deastringency treatment on flesh disorders induced by mechanical damage in persimmon. Biochemical and microstructural studies. Food Chemistry. 145 , 454-463. https://doi.org/10.1016/j.foodchem.2013.08.054 
Ortiz, G., Sugaya, S., Sekozawa, Y., Ito, H., Wada, K., \& Gemma, H. (2005). Efficacy of 1-methylcyclopropene (1-MCP) in prolonging the shelf-life of Rendaiji persimmon (Diospyros kaki) fruits previously subjected to astringency removal treatment. Journal of the Japanese Society for Horticultural Science. 74(3), 248-254. https://doi.org/10.2503/jjshs.74.248

Park, Y.M., \& Lee, Y.J. (2005). Ripening responses of 'Fuyu' persimmon fruit to exogenous ethylene and subsequent shelf temperature. Acta Horticulturae. 685 , 151-156. https://doi.org/10.17660/ActaHortic.2005.685.17

Park, S. J., Park, H., \& Kim, C. (2003). Influence of ethylene on fruit tissue in 'Cheongdobansi' persimmon (Diospyros kaki). Journal of the Korean Society for Horticultural Science. 44(1), 62-65.

Pérez-Munuera, I., Hernando, I., Larrea, V., Besada, C., Arnal, L., \& Salvador, A. (2009b). Microstructural study of chilling injury alleviation by 1methylcyclopropene in persimmon. HortScience. 44(3), 742-745. https://doi.org/10.21273/HORTSCI.44.3.742

Pérez-Munuera, I., Quiles, A., Larrea, V., Arnal, L., Besada, C., \& Salvador, A.(2009a). 'Microstructure of persimmon treated by hot water to alleviate chilling injury'. Acta Horticulturae. 833, 251-256. https://doi.org/10.17660/ActaHortic.2009.833.40

Perucho, R. (2015). Antecedentes e importancia económica. In: Badenes, L., Intrigliolo, D., Salvador, A., \& Vicent, A., (Eds.). El cultivo del caqui. Valencia. pp. 18-34

Perucho, R. (2018). Evolution of production of the 'RojoBrillante' cultivar in Spain and its impact on markets. Acta Horticulturae. 1195, 1-8. https://doi.org/10.17660/ActaHortic.2018.1195.1

Pesis, E., Levi, A., \& Ben-Arie, R. (1988). Role of acetaldehyde production in the removal of astringency from persimmon fruits under various modified 
atmospheres. Journal of Food Science. 53, 153-156. https://doi.org/10.1111/j.1365-2621.1988.tb10197.x

Ramin, A. A. (2008). Shelf-life extension of ripe non-astringent persimmon fruit using 1-MCP. Asian Journal of Plant Sciences. 7(2), 218-222. https://doi.org/10.3923/ajps.2008.218.222

Salvador, A., Arnal, L., Besada, C., Larrea, V., Quiles, A., \& Pérez-Munuera, I. (2007). Physiological and structural changes during ripening and desastringency treatment of persimmon fruit 'RojoBrillante'. Postharvest Biology and Technology. 46 (2), 181-188. https://doi.org/10.1016/j. postharvbio.2007.05.003

Salvador, A., Arnal, L., Carot, J. M., Carvalho, C. P., \& Jabaloyes, J. M. (2006). Influence of different factors on firmness and color evolution during the storage of persimmon cv. 'Rojo Brillante'. Journal of Food Science. 71(2), 169-175. https://doi.org/10.1111/j.1365-2621.2006.tb08921.x

Salvador, A., Arnal, L., Monterde, A., \& Martínez-Jávega, J. (2005). Influence of ripening stage at harvest on chilling injury symptoms of persimmon cv. RojoBrillante stored at different temperatures. Food Science and Technology International. 11(5), 359-365. https://doi.org/10.1177/1082013205057941

Shahkoomahally, S., \& Ramezanian, A. (2013). Analytical and interpretation statistical of relationship between total antioxidant activity, ascorbic acid content, total phenolic compounds, soluble tannin and chromatic parameters of persimmon (Diospyros kaki) cv. Shiraz during cold storage. Agricultural Communications. 1, 17-22.

Sugiura, A., \& Tomana, T. (1983). Relationships of ethanol production by seeds of different types of Japanese persimmons and their tannin content. HortScience. 18(3), 319-321.

Taira, S., Itamura, H., Abe, K., \& Watanabe, S. (1989). Comparison of the characteristics of removal of astringency in two Japanese persimmon (Diospyros kaki) cultivars, Denkuro and Hiratanenashi. Journal of the 
Japanese Society for Horticultural Science. 58(2), 319-325. https://doi.org/10.2503/jjshs.58.319

Taira, S., Oba, S., \& Watanabe, S. (1992a). Removal of astringency from Hiratanenashi persimmon fruit with a mixture of ethanol and carbon dioxide. Journal of the Japanese Society for Horticultural Science. 61(2), 437-443. https://doi.org/10.2503/jjshs.61.437

Taira, S, Ono, M., \& Matsumoto, N. (1997). Reduction of persimmon astringency by complex formation between pectin and tannins. Postharvest Biology and Technology. 12, 265-71. https://doi.org/10.1016/S0925-5214(97)00064-1

Taira, S., Satoh, I., \& Watanabe, S. (1992b). Relationship between differences in the ease of removal of astringency among fruits of Japanese persimmon (Diospyros kaki Thunb.) and their ability to accumulate ethanol and acetaldehyde. Journal of the Japanese Society for Horticultural Science. 60(4), 1003-1009. https://doi.org/10.2503/jjshs.60.1003

Tanaka, T., Matsuo, Y., \& Kouno, I. (2010). Chemistry of secondary polyphenols produced during processing of tea and selected foods. International Journal of Molecular Sciences. 11(1), 14-40. https://doi.org/10.3390/ijms11010014

Tessmer, M. A., Besada, C., Hernando, I., Appezzato-da-Glória, B., Quiles, A., \& Salvador, A.(2016). Microstructural changes while persimmon fruits mature and ripen. Comparison between astringent and non-astringent cultivars. Postharvest Biology and Technology. 120, 52-60. https://doi.org/10.1016/j.postharvbio.2016.05.014

Tessmer, M.A., Kluge, R.A., \& Appezzato-da-Glória, B. (2014). The accumulation of tannins during the development of 'Giombo' and 'Fuyu' persimmon fruits. Scientia Horticulturae. 172, 292-299. https://doi.org/10.1016/j.scienta.2014.04.023

Testoni, A. (2002). Post-harvest and processing of persimmon fruit. In: Bellini, E., Giordani, E., (eds.). Options Méditerranéennes: Série A. Séminaires 
Méditerranéens 51, CIHEAM-IAMZ, Zaragoza, Spain, pp. 53-66. http://om.ciheam.org/article.php?IDPDF=2600062

Tetsumura, T., Giordani, E. \& Tao, R. (2008). Persimmon (kaki), In: C. Kole and T.C. Hall (eds.). Compendium of transgenic crop plants: transgenic tropical and subtropical fruits and nuts. Blackwell Publishing, Oxford. pp. 235-257

Tsviling, A., Nerya, O., Gizis, A., Sharabi-Nov, A., \& Ben-Arie, R. (2003). Extending the shelf-life of 'Triumph' persimmons after storage, with 1MCP. ActaHorticulturae. 53-58. https://doi.org/10.17660/ActaHortic.2003.599.4

Watkins, C. B. (2008). Overview of 1-methylcyclopropene trials and uses for edible horticultural crops. HortScience. 43(1), 86-94. https://doi.org/10.21273/HORTSCI.43.1.86

Woolf, A.B. \& Ben Arie, R. (2011). Persimmon (Diospyros kaki L.). In: Yahia, E.M. (Ed.), Postharvest Biology and Technology of Tropical and Subtropical Fruits. Wood-head Publishing, Cambridge, UK. pp. 66-193.

Woolf, A. B., MacRae, E. A., Spooner, K. J., \& Redgwell, R. J. (1997). Changes to physical properties of the cell wall and polyuronides in response to heat treatment of 'Fuyu' persimmon that alleviate chilling injury. Journal of the American Society for Horticultural Science. 122(5), 698-702. https://doi.org/10.21273/JASHS.122.5.698

Yakushiji, H., \& Nakatsuka, A. (2007). Recent persimmon research in Japan. Japanese Journal of Plant Science. 1, 42-62.

Yamada M., \& Sato A. (2013). Two astringent persimmon cultivars released by naro institute of fruit tree science, Japan. In: $V$ International Symposium on Persimmon. pp. 145-149.

Yamada, M., Taira, S., Ohtsuki, M., Sato, A., Iwanami, H., Yakushiji, H., \& Li, G. (2002). Varietal differences in the ease of astringency removal by carbon dioxide gas and ethanol vapor treatments among Oriental astringent 
persimmons of Japanese and Chinese origin. Scientia Horticulturae. 94(1), 63-72. https://doi.org/10.1016/S0304-4238(01)00367-3

Yamada, M., Wang, R., Yamane, H., Sato, A., \& Hirakawa, N. (1995). Comparison in the variations in fruit maturing time, fruit weight. Japanese Society for Horticultural Science. 64(2), 227-233. https://doi.org/10.2503/jjshs.64.227

Yesiloglu, T., Cimen, B., Incesu, M., \& Yilmaz, B. (2018). Genetic diversity and breeding of persimmon. In: Soneji, J., Nageswara-Rao, M. (eds.). Breeding and Health Benefits of Fruit and Nut Crops. IntechOpen Limited, London.

Yonemori, K., Ikegami, A., Kanzaki, S., \& Sugiura, A. (2003). Unique features of tannin cells in fruit of pollination constant non-astringent persimmons. Acta Horticulturae. 601(1), 31-35. https://doi.org/10.17660/ActaHortic.2003.601.3

Yonemori, K., Itai, A., Nakano, R. \& Sugiura, A. (1996). Role of calyx lobes in gas exchange and development of persimmon fruit. Journal of the American Society for Horticultural Science. 121, 676-679. https://doi.org/10.21273/JASHS.121.4.676

Zhang, Z., Zhang, Y., Huber, D. J., Rao, J., Sun, Y., \& Li, S. (2010). Changes in prooxidant and antioxidant enzymes and reduction of chilling injury symptoms during low-temperature storage of 'Fuyu' persimmon treated with 1-methylcyclopropene. HortScience. 45(11), 1713-1718. https://doi.org/10.21273/HORTSCI.45.11.171 
II. OBJECTIVES 



\section{GENERAL OBJECTIVE}

This Thesis addressed two main objectives: 1) To optimize the pre- and postharvest technology so as to guarantee the quality of 'Rojo Brillante' persimmon after cold storage and transportation to overseas markets. 2) To evaluate the behavior of foreign persimmon varieties under Mediterranean conditions in order to extend the varietal range.

\section{SPECIFIC OBJECTIVES}

1) To optimize the postharvest technology to guarantee fruit quality on arrival at overseas markets

To study the factors involved in the internal flesh browning that appears during long shipments at low temperatures and to implement the technology to alleviate this disorder and thus preserve fruit quality.

To evaluate a new wax containing ethanol as a method to remove persimmon astringency during cold storage in shipments to overseas markets.

2) To optimize the pre- and postharvest technology used to preserve fruit quality during cold storage

To investigate the effect of multiple preharvest applications of gibberellic acid on the evolution of fruit maturation and its influence on fruit quality during cold storage.

To optimize the postharvest handling of organic persimmon in order to store the fruit while preserving quality. 
3) To study the postharvest behavior of non-astringent varieties belonging to the IVIA germplasm bank in order to extend the varietal range in the Mediterranean production area

To establish the optimal harvest time for each variety studied and to evaluate their postharvest behavior. 


\section{RESULTS}



III.1. POSTHARVEST TECHNOLOGY TO GUARANTEE FRUIT QUALITY ON ARRIVAL AT OVERSEAS MARKETS

CHAPTERS I and II 



\section{CHAPTER I}

\section{Effect of temperature during and immediately after $\mathrm{CO}_{2}$-deastringency treatment on internal flesh browning after cold storage of persimmon fruit}

\section{Ayoub Fathi Najafabadi, Alejandra Salvador, Pilar Navarro, Rebeca Gil, Cristina Besada}

Centro de Tecnología Postcosecha del Instituto Valenciano de Investigaciones

Agrarias (IVIA), Carretera Moncada-Náquera, Km. 4.5, 46113, Moncada,

Valencia, Spain

Reference: Siencia Horticulturae, 2020, 268, 109363.

https://doi.org/10.1016/j.scienta.2020.109363 



\begin{abstract}
Currently, a major cause of postharvest loss of 'Rojo Brillante' persimmon, the variety mainly cultivated in the Mediterranean Region, is "internal flesh browning" manifestation after storage or shipping at low temperature, whose causes remain unknown. 'Rojo Brillante' is an astringent low temperaturesensitive cultivar. Thus fruit is routinely submitted to high $\mathrm{CO}_{2}$ treatment to remove astringency, and also to $1-\mathrm{MCP}$ treatment before being stored to retard flesh gelling and drastic softening, the main chilling injury symptoms. This study investigates the influence of temperature during $\mathrm{CO}_{2}$ deastringency treatment and immediately after its application on the incidence of 'internal flesh browning' in persimmon fruit. Our results revealed for the first time that the temperature immediately after the $\mathrm{CO}_{2}$ deastringency treatment was the main factor implied in this alteration. The fruit transferred directly to cold storage after the $\mathrm{CO}_{2}$ treatment showed 'internal flesh browning' after 41 storage $\mathrm{d}$ at $1{ }^{\circ} \mathrm{C}$, while a 24- hour attemperation period at $20{ }^{\circ} \mathrm{C}$ before storage prevented this disorder from appearing. The main effect of the attemperation period was the enhanced release of $\mathrm{CO}_{2}$ from fruit after the $\mathrm{CO}_{2}$ treatment, which resulted in less acetaldehyde $(\mathrm{AcH})$ accumulating after $24 \mathrm{~h}$. Moreover, the temperature of the $\mathrm{CO}_{2}$ application was observed to influence 'internal flesh browning' severity as $\mathrm{AcH}$ accumulated at higher concentrations in the fruit treated at $20{ }^{\circ} \mathrm{C}$ than at $12{ }^{\circ} \mathrm{C}$. Our preliminary hypothesis is that $\mathrm{AcH}$ can act as a precursor of reactive oxygen species that would be implied in this disorder's development.
\end{abstract}

Keywords: persimmon, attemperation period, flesh browning, gas exchange, respiration 


\section{Introduction}

Currently, one of the most important causes of postharvest losses of 'Rojo Brillante' fruits is the manifestation of an internal flesh browning disorder, whose causes remain unknown. The onset of this browning is located in the internal fruit area, around the core zone, and it extends to the more external flesh areas. This disorder has been mainly observed after prolonged cold storage and long shipping at low temperature, which can initially lead us to think that it is a chilling injury symptom. However, 'Rojo Brillante' chilling injury has been widely studied (Salvador et al., 2004; Pérez-Munera et al., 2009) and the internal browning reported herein has never been described as a chilling injury symptom, so other factors than storage temperature must be implied in this disorder manifestation.

It is worth to note that despite its chilling injury sensitiveness, 'Rojo Brillante' persimmons are usually stored and shipped at temperatures between $0-1{ }^{\circ} \mathrm{C}$ as fruit are previously subjected to treatment with 1-methylcyclopropene (1$\mathrm{MCP}$ ) that considerably delays the main chilling injury symptom, a drastic fruit softening (Besada et al., 2008; Pérez-Munera et al., 2009).

On the other hand, 'Rojo Brillante' persimmons are routinely submitted to a $\mathrm{CO}_{2}$ treatment to remove astringency before commercialisation. The recommended $\mathrm{CO}_{2}$ treatment conditions for 'Rojo Brillante' persimmons are $95 \% \mathrm{CO}_{2}-20{ }^{\circ} \mathrm{C}-24 \mathrm{~h}$ (Salvador et al., 2007). However, the $\mathrm{CO}_{2}$ treatment is quite commonly applied at ambient temperature because treatment chambers do not always have temperature control. This implies that the $\mathrm{CO}_{2}$ treatment temperature can vary between $20^{\circ} \mathrm{C}$ to $12{ }^{\circ} \mathrm{C}$ from the beginning to the end of the season.

In the case that fruit must be kept at low temperature for long periods, applying the $\mathrm{CO}_{2}$ treatment after cold storage rather than before it is recommended to preserve fruit firmness. Nevertheless, this is not possible when fruit is sent in cold containers overseas as in this case the deastringency treatment needs to be applied before shipment. In these cases, one recommended handling practice is to attemperate fruit for a 12-24-hour period immediately after the deastringency treatment, before being transferred to cold storage. This attemperation period helps the deastringency 
process to be completed, mainly when applied at lower temperatures or for shorter durations than those recommended (Besada et al., 2010). However due to logistical issues, this practice is not always carried out in packing houses.

In this context, the $\mathrm{CO}_{2}$ deastringency treatment, and the handling conditions to which the fruit is subjected after it are most probably the factors implied in the internal browning that 'Rojo Brillante' persimmons display after cold storage. Hence this study aimed to investigate the effect of $\mathrm{CO}_{2}$ treatment temperature and the attemperation period between the deastringency treatment and the transfer to cold storage on the incidence of persimmon flesh browning.

\section{Materials and Methods}

\subsection{Plant material and treatments}

Persimmon (Diospyros kaki Lf.) cv. Rojo Brillante fruit were harvested in I'Alcudia (Spain) at midseason. After harvest, fruit were taken to the Instituto Valenciano de Investigaciones Agrarias (IVIA), where they were selected according to homogenous colour and absence of external damage. One lot of 20 fruit was analysed to determine the fruit maturity stage at harvest [colour index of 6.8 , firmness of $53 \mathrm{~N}$ and soluble tannins content of $0.6 \% \mathrm{FW}$. The remaining fruit were submitted to the 1-MCP treatment $\left(500 \mathrm{~nL} \mathrm{~L}^{-1}\right.$ of 1-MCP for $24 \mathrm{~h}$ at room $\left.\mathrm{T}^{\mathrm{a}}\right)$. Then fruit were divided into two homogenous lots. One lot was submitted to the $\mathrm{CO}_{2}$ deastringency treatment under standard conditions $\left(95 \% \mathrm{CO}_{2}-20{ }^{\circ} \mathrm{C}-24 \mathrm{~h}\right.$ ), while the other lot was submitted to the $\mathrm{CO}_{2}$ treatment at $12{ }^{\circ} \mathrm{C}\left(95 \% \mathrm{CO}_{2}-12{ }^{\circ} \mathrm{C}-24 \mathrm{~h}\right)$. Then the fruit from each treatment were once again divided into two lots: one was directly transferred to a $1{ }^{\circ} \mathrm{C}$ storage chamber for up to $41 \mathrm{~d}$; the other was kept for $24 \mathrm{~h}$ at $20{ }^{\circ} \mathrm{C}$ (attemperation period) before being transferred to the storage chamber at $1^{\circ} \mathrm{C}$.

In this way, four different treatments were assayed: 
$>12{ }^{\circ} \mathrm{C}$-D-fruit: The deastringency treatment was applied at $12{ }^{\circ} \mathrm{C}$ and then fruit were transferred directly to the storage chamber at $1{ }^{\circ} \mathrm{C}(\mathrm{HR}$ $85 \%)$.

$>12{ }^{\circ} \mathrm{C}$-AT-fruit: After applying the deastringency treatment at $12{ }^{\circ} \mathrm{C}$, fruit were attemperated for $24 \mathrm{~h}$ at $20^{\circ} \mathrm{C}$ before being transferred to the storage chamber at $1{ }^{\circ} \mathrm{C}(\mathrm{HR} 85 \%)$.

$>20^{\circ} \mathrm{C}$-D-fruit: The deastringency treatment was applied at $20{ }^{\circ} \mathrm{C}$ and then fruit were directly transferred to the storage chamber at $1{ }^{\circ} \mathrm{C}(\mathrm{HR}$ $85 \%)$.

$>20^{\circ} \mathrm{C}$-AT-fruit: After the deastringency treatment applied at $20{ }^{\circ} \mathrm{C}$, fruit were attemperated for $24 \mathrm{~h}$ at $20^{\circ} \mathrm{C}$ before being transferred to the storage chamber at $1{ }^{\circ} \mathrm{C}(\mathrm{HR} 85 \%)$.

All the fruit were stored for $41 \mathrm{~d}$ at $1{ }^{\circ} \mathrm{C}$, plus a 3-day shelf-life period at $20^{\circ} \mathrm{C}$, and were periodically evaluated throughout the assay period.

According to the diagram shown in Figure 1, 20 fruit of each treatment were removed from the chambers and evaluated at the following time points:

Day 1- fruit were evaluated immediately after the $\mathrm{CO}_{2}$ treatment $(0 \mathrm{~h})$ and after 2, 4, 6 and $24 \mathrm{~h}$. The evaluated parameters were the following: soluble tannins content, carbon dioxide $\left(\mathrm{CO}_{2}\right)$, ethanol $(\mathrm{EtOH})$ and acetaldehyde $(\mathrm{AcH})$ production of the whole fruit, and the $\mathrm{EtOH}$ and $\mathrm{AcH}$ concentrations in juice.

Day 2- fruit were re-evaluated $48 \mathrm{~h}$ after completing the $\mathrm{CO}_{2}$ treatment. At this time point, the fruit corresponding to the $12{ }^{\circ} \mathrm{C}-\mathrm{D}$ and $20^{\circ} \mathrm{C}-\mathrm{D}$ treatments had been kept for $2 \mathrm{~d}$ at $1{ }^{\circ} \mathrm{C}$, while the $12{ }^{\circ} \mathrm{C}$-AT and $20^{\circ} \mathrm{C}$-AT-fruit had been kept for $1 \mathrm{~d}$ at $20{ }^{\circ} \mathrm{C}$ (attemperation period), plus $1 \mathrm{~d}$ at $1{ }^{\circ} \mathrm{C}$. The determined parameters were the same as those mentioned for Day 1 .

Day 14 and Day 41- after 14 and $41 \mathrm{~d}$ of storage at $1{ }^{\circ} \mathrm{C}$, fruit were reevaluated. Moreover after $41 \mathrm{~d}$, one lot of 20 fruit was transferred to $20^{\circ} \mathrm{C}$ to simulate a 3-day shelf-life period at $20{ }^{\circ} \mathrm{C}$. In addition to the parameters mentioned for Day 1 , the incidence of the external and internal disorders was determined after 14 and $41 \mathrm{~d}$ of storage, and the subsequent shelf-life period. 


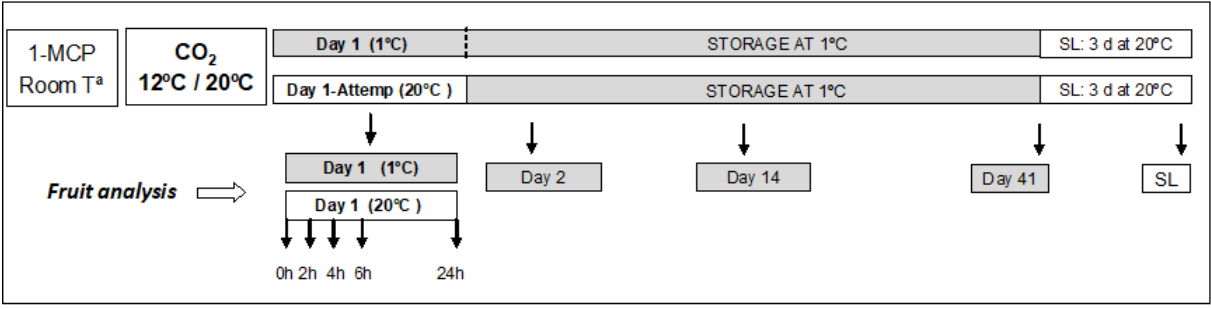

Fig. 1. Diagram of the performed assay. 1-MCP: application of the 1methyciclopropene treatment; $\mathrm{CO}_{2}$ : application of the deastringency treatment at 12 ${ }^{\circ} \mathrm{C}$ or $20^{\circ} \mathrm{C}$; Attemp: atemperation period $\left(24 \mathrm{~h}-20^{\circ} \mathrm{C}\right)$; SL: shelf-life period of 3 days at $20^{\circ} \mathrm{C}$.

\subsection{Analytical determinations}

\subsubsection{Firmness and color}

The firmness and colour index of the fruit at harvest were determined on 20 fruit following the methodology described by Novillo et al. (2014). Colour was expressed as IC $=1000 \mathrm{a} / \mathrm{Lb}$, where ' $\mathrm{L}$ ', ' $\mathrm{a}$ ' and ' $\mathrm{b}$ ' are Hunter parameters. Firmness was expressed as load in Newton (N) to break flesh at tow equidistant locations in the equatorial region of each fruit after epicarp removal.

\subsubsection{Soluble tannins, $\mathrm{AcH}$ and $\mathrm{EtOH}$ in juice}

The soluble tannins content (ST), the $\mathrm{AcH}$ and EtOH concentrations in juice and sensory astringency, were determined on three individual fruit per treatment at each analysis time. To this end, three fruit were cut into four longitudinal quarters. Two of the opposite quarters were sliced and frozen $\left(-20^{\circ} \mathrm{C}\right)$ to later determine ST by the Folin-Denis method, as described by Taira (1996). Soluble tannin content was expressed as \% of fresh weight. One of the remaining quarters was placed in an electric juice extractor (Moulinex model 753, Spain) and was filtered through cheesecloth. The obtained juice was used to determine the $\mathrm{AcH}$ and $\mathrm{EtOH}$ concentrations (three juices per treatment and analysis time). The $\mathrm{AcH}$ and $\mathrm{EtOH}$ concentrations were analysed by headspace 
gas chromatography following the conditions described by Besada et al. (2016). The results were expressed as $\mathrm{mg} 100 \mathrm{~mL}^{-1}$.

\subsubsection{Sensory evaluation of astringency}

The remaining fruit quarter underwent a sensory evaluation of astringency, which was performed at the Sensory Laboratory of the Postharvest Department (IVIA) by a panel of experts. Three expert judges with more than 8 years of experience in astringency evaluation rated the astringency of the persimmon samples following a 5-point scale, which went from 0 meaning non-astringent to 4 denoting intensely astringent. The fruit quarter was peeled, and cut in $1.5 \mathrm{~cm}$ thick slices that were placed in glass cups identified by randomly assigned 3-digit codes; each judge analyzed individually the three fruits of each lot. Samples were served at room temperature and panellists were provided with crackers and a glass of water for palate cleansing, which they used between samples.

\subsection{4. $\mathrm{CO}_{2}, \mathrm{AcH}$ and $\mathrm{EtOH}$ release}

The $\mathrm{CO}_{2}, \mathrm{AcH}$ and $\mathrm{EtOH}$ productions of whole fruit were determined from three other individual fruit from each lot. To this end, fruit were individually sealed in 1-litre glass jars. On Day 1, fruit were kept enclosed for 30 min, while the measurement time was $2 \mathrm{~h}$ on Days 2, 14 and 41 . As explained above, in the analyses corresponding to Day 1-0 h, the glass jars were kept at $20^{\circ} \mathrm{C}$ or 1 ${ }^{\circ} \mathrm{C}$, depending on the treatment. In the analysis carried out after 2, 14 and $41 \mathrm{~d}$ of cold storage, the glass jars were kept at $1{ }^{\circ} \mathrm{C}$, while fruit were enclosed at 20 ${ }^{\circ} \mathrm{C}$ in the analysis performed after the shelf-life period. The $\mathrm{CO}_{2}, \mathrm{AcH}$ and $\mathrm{EtOH}$ productions were analysed by injecting $1 \mathrm{~mL}$ of headspace in a Perkin Elmer gas chromatograph according to the conditions described by Novillo et al. (2014). $\mathrm{CO}_{2}$ release was expressed as $\mathrm{mL} \mathrm{kg}^{-1} \mathrm{~h}^{-1}$ while $\mathrm{AcH}$ and EtOH release as $\mu \mathrm{Lg}^{-1} \mathrm{~h}^{-1}$.

\subsubsection{Browning incidence and severity}

External and internal brownings were visually evaluated. Browning severity was determined according to the scale shown in Figure 2. 


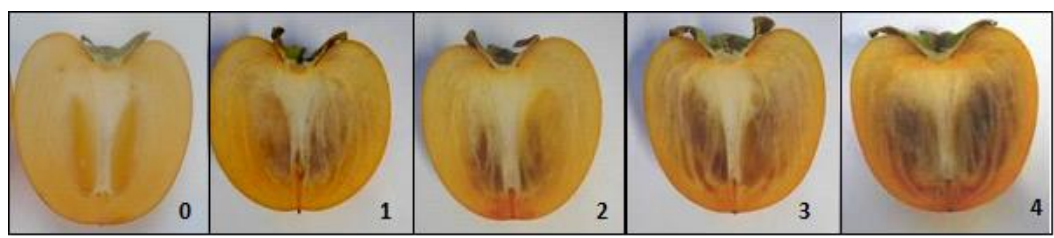

Fig. 2. Scale used to evaluate internal browning severity, in which $0=$ absence, $1=$ slight browning in less than $50 \%$ of the pulp, $2=$ intense browning in less than $50 \%$ of the pulp, $3=$ intense browning in $50-70 \%$ of the pulp, and $4=$ intense browning in more than $70 \%$ of the pulp.

To evaluate the incidence and severity of the disorder, the following browning index (BI) was calculated according to Khademi et al. (2013):

$\mathrm{BI}=\Sigma\left[\left(\right.\right.$ browning severity) $\times\left(\mathrm{n}^{\circ}\right.$ of fruit at each browning severity) $] / 4 \times$ total $n^{\circ}$ of fruit

\subsubsection{Statistical Analysis}

Data were subjected to an analysis of variance. At each evaluation period, the mean values of the four assayed treatments were compared by the least significant difference test $(P=0.05)$ using the Statgraphics Plus 5.1 software application (Manugistics Inc., Rockville, MD, USA).

\section{Results and discussion}

\subsection{External and internal disorders and fruit firmness}

The visual evaluation of fruit revealed the absence of external disorders throughout the study period. After $41 \mathrm{~d}$ at $1{ }^{\circ} \mathrm{C}$ plus the shelf-life period, the fruit from the four assayed treatments showed a similar external quality to that noted at harvest.

The fruit internal evaluation showed that any flesh disorder was manifested in the fruit that was attempered after the $\mathrm{CO}_{2}$ treatment for $24 \mathrm{~h}$ prior to cold 
storage $\left(12{ }^{\circ} \mathrm{C}-\mathrm{A}\right.$ and $\left.20{ }^{\circ} \mathrm{C}-\mathrm{A}\right)$ (Fig. 3). Nevertheless, the fruit transferred directly to cold chambers $\left(12{ }^{\circ} \mathrm{C}-\mathrm{D}\right.$ and $20^{\circ} \mathrm{C}$-D-fruit) showed flesh browning symptoms after $41 \mathrm{~d}$ at $1{ }^{\circ} \mathrm{C}\left(12{ }^{\circ} \mathrm{C}-\mathrm{D}\right.$ and $20^{\circ} \mathrm{C}$-D-fruit). The browning index revealed that the incidence and severity of internal flesh browning were more marked in those fruit submitted to the $\mathrm{CO}_{2}$ treatment at $20^{\circ} \mathrm{C}(\mathrm{BI}=0.24)$ than in those treated at $12{ }^{\circ} \mathrm{C}(\mathrm{BI}=0.18)$ (data not shown). The browning indices increased in both cases after the 3-day shelf-life period at $20{ }^{\circ} \mathrm{C}$ when, once again, the disorder manifestation was more marked in the $20{ }^{\circ} \mathrm{C}$-D-fruit $(\mathrm{Bl}=0.46)$ than in $12^{\circ} \mathrm{C}$-D-fruit $(\mathrm{Bl}=0.32)$.

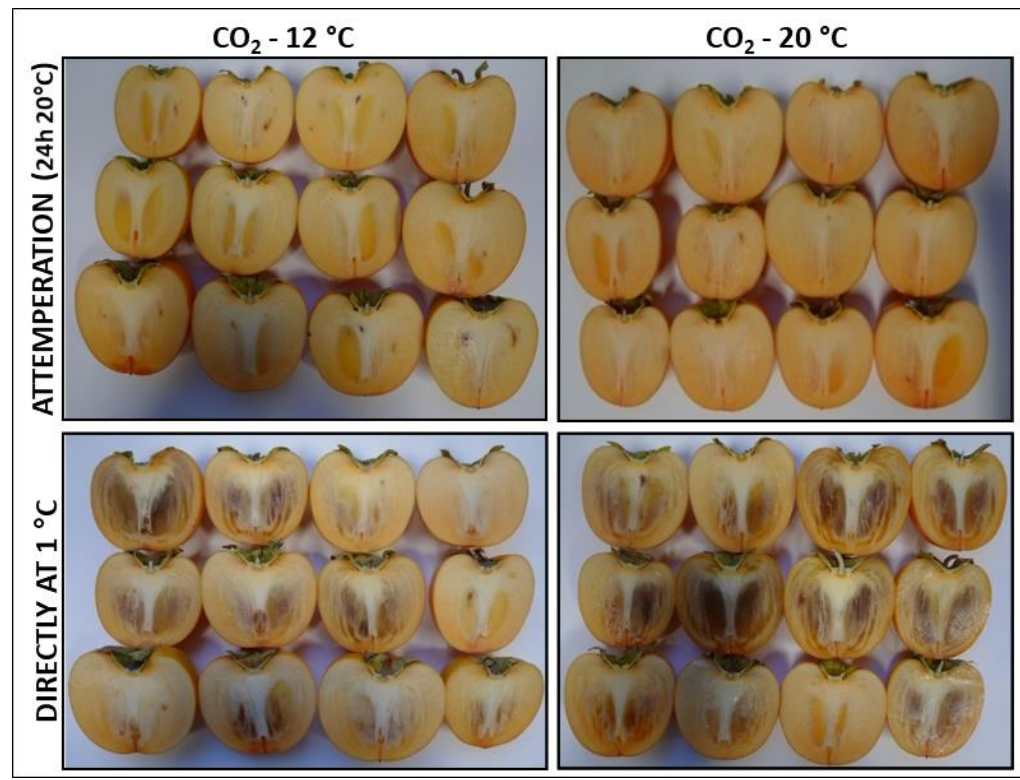

Fig. 3. The insides of the fruits submitted to the $\mathrm{CO}_{2}$ treatment at $12{ }^{\circ} \mathrm{C}$ or $20{ }^{\circ} \mathrm{C}$, and then transferred directly to cold storage or after an attemperation period lasting $24 \mathrm{~h}$ at $20^{\circ} \mathrm{C}$. The pictures were taken after $41 \mathrm{~d}$ at $1{ }^{\circ} \mathrm{C}$, plus $3 \mathrm{~d}$ at $20^{\circ} \mathrm{C}$. Internal browning was evaluated according to the scale displayed in Figure 2. 
Regarding fruit firmness, mean value at harvest time was $53 \mathrm{~N}$. Not relevant changes were detected during cold storage, but fruit from all treatments suffered softening to values close to $30 \mathrm{~N}$ during the shelf-life period. Statistical analysis of firmness values revealed not significant differences among treatments after this period. This pattern of firmness loss, in which the main changes are observed after transferring fruit treated with 1-MCP from low to moderate temperature, has been previously described for 'Rojo Brillante' (Pérez-Munera et al., 2009; Novillo et al., 2015)

\subsection{Soluble tannins and sensory astringency}

As shown in Figure 4, the deastringency treatment lowered soluble tannins (ST) from $0.6 \%$ at harvest to $0.2-0.25 \%$ once treatment ended (D1-Oh). At this time point, the ST concentration was slightly lower in the fruit treated at $20^{\circ} \mathrm{C}$ than in those treated at $12{ }^{\circ} \mathrm{C}$. In all cases, the panellists detected "medium astringency" in the fruit (data not shown). After 2, 4 and $6 \mathrm{~h}$ following treatment, a gradual decrease in soluble tannins took place in all the treatments, and the decline in ST was faster in the fruit treated at $20^{\circ} \mathrm{C}$ than at $12{ }^{\circ} \mathrm{C}$. Moreover in both cases, the tannins insolubilisation process was accelerated with the attemperation period. Thus $6 \mathrm{~h}$ after the deastringency treatment ended, the $20^{\circ} \mathrm{C}$-A-fruit had an ST content of $0.02 \%$, evaluated by the panellists as 'non-astringent', while the the $20^{\circ} \mathrm{C}$-D-fruit obtained values of $0.06 \%$ and the panellists detected "residual astringency". At this time point, all the fruit treated at $12{ }^{\circ} \mathrm{C}$ had an ST content of $0.1 \%$ and were evaluated as "medium astringency". After $24 \mathrm{~h}$, all the treatments achieved ST values close to $0.02 \%$ and were evaluated as 'non-astringent'. These values did not further change during the remaining storage time. 


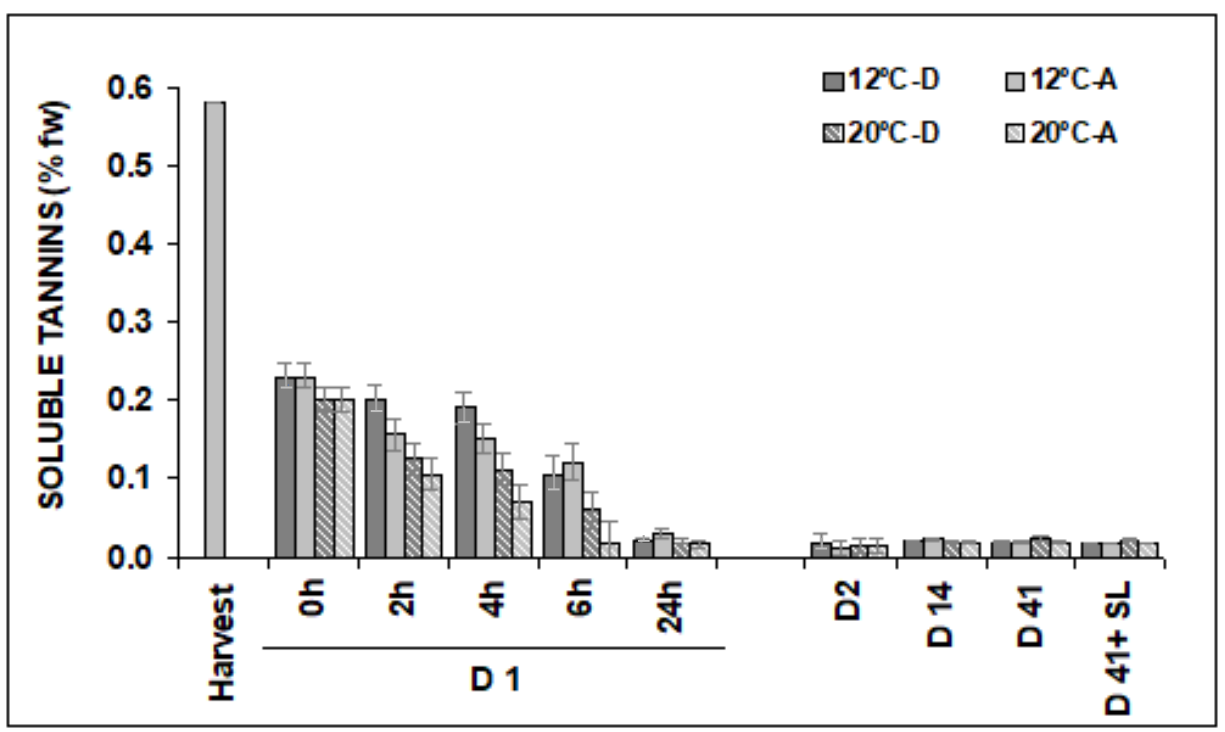

Fig. 4. Soluble Tannins. Evolution of the concentration of soluble tannins (\% FW) in the persimmon fruit submitted to the $\mathrm{CO}_{2}$ deastringency treatment $\left(95 \% \mathrm{CO}_{2}\right)$ at $12{ }^{\circ} \mathrm{C}$ and $20{ }^{\circ} \mathrm{C}$, and then transferred directly to cold storage at $1{ }^{\circ} \mathrm{C}\left(12{ }^{\circ} \mathrm{C}-\mathrm{D}\right.$ and $\left.20{ }^{\circ} \mathrm{C}-\mathrm{D}\right)$ or attemperated for $24 \mathrm{~h}$ at $20^{\circ} \mathrm{C}\left(12{ }^{\circ} \mathrm{C}-\mathrm{A}\right.$ and $\left.20^{\circ} \mathrm{C}-\mathrm{A}\right)$ before being cold stored for $41 \mathrm{~d}$ at $1{ }^{\circ} \mathrm{C}$, plus a 3 -day shelf-life period at $20^{\circ} \mathrm{C}$. Vertical bars represent the LSD intervals $(p=0.05)$.

\subsection{Acetaldehyde $(\mathrm{AcH})$ and ethanol (EtOH) concentrations in fruit juice}

The $\mathrm{CO}_{2}$ treatments applied at both $12{ }^{\circ} \mathrm{C}$ and $20^{\circ} \mathrm{C}$ resulted in marked $\mathrm{AcH}$ accumulation in fruit, with values coming close to zero at harvest and at around 1-1.5 mg $100 \mathrm{~mL}^{-1}$ immediately after treatment (D1-0h), with no statistical differences among treatments (Fig. 5A). For the next $6 \mathrm{~h}$, gradual $\mathrm{AcH}$ accumulation was observed in all the fruit.

It is noteworthy that after $24 \mathrm{~h}, \mathrm{AcH}$ concentration sharply dropped in the ATfruit to values below $1 \mathrm{mg} 100 \mathrm{~mL}^{-1}$, while $\mathrm{AcH}$ increased in the fruit transferred directly to cold storage ( $D$-fruit). This increase was more marked in the fruits treated with $\mathrm{CO}_{2}$ at $20{ }^{\circ} \mathrm{C}\left(20{ }^{\circ} \mathrm{C}-\mathrm{D}\right)\left(5 \mathrm{mg} 100 \mathrm{~mL}^{-1}\right)$ than in those treated at $12{ }^{\circ} \mathrm{C}\left(12{ }^{\circ} \mathrm{C}-\mathrm{D}\right)\left(3 \mathrm{mg} 100 \mathrm{~mL}^{-1}\right)$. 
On Day 2, a drop in the $\mathrm{AcH}$ concentration took place to values that came close to $1 \mathrm{mg} 100 \mathrm{~mL}^{-1}$ for the $\mathrm{CO}_{2}$-treated fruit at $12{ }^{\circ} \mathrm{C}$, with no differences between the AT-fruit and the D-fruit. Nevertheless, the $\mathrm{CO}_{2}$-treated fruit at $20{ }^{\circ} \mathrm{C}$ had increased $\mathrm{AcH}$ content, and the D-fruit obtained higher values than the AT-fruit.

As storage advanced, all the fruit obtained values between 2.5 and $5 \mathrm{mg}$ $100 \mathrm{~mL}^{-1}$, with no differences between the AT-fruit and D-fruit. Only when fruit were transferred and stored during the shelf-life period did the $\mathrm{AcH}$ values become significantly higher in the fruit transferred directly to cold storage.

Regarding $\mathrm{EtOH}$ concentration (Fig. $5 \mathrm{~B}$ ), the $\mathrm{CO}_{2}$-treatment temperature had a clear effect as the $\mathrm{CO}_{2}$-treated fruit at $20{ }^{\circ} \mathrm{C}$ had higher values than those $\mathrm{CO}_{2}$-treated at $12{ }^{\circ} \mathrm{C}$, as shown by all the measurements taken until D2. During the first $6 \mathrm{~h}$, the effect of the attemperation period was not evident, and it was only after $24 \mathrm{~h}$ when this practice was seen to have a clear effect on EtOH accumulation. At this point, and similarly to that observed in $\mathrm{AcH}, \mathrm{EtOH}$ content was higher in the fruit directly transferred to cold storage. These differences between $D$-fruit and A-fruit disappeared at $\mathrm{D}-2$, but the $\mathrm{CO}_{2}$-treated fruit at $20{ }^{\circ} \mathrm{C}$ still had a higher $\mathrm{EtOH}$ concentration than that $\mathrm{CO}_{2}$-treated at $12{ }^{\circ} \mathrm{C}$. No relevant differences were detected among treatments for the next 14 storage days. However, at 41 storage days, EtOH content did not change in D-fruit, but dropped in A-fruit. After the shelf-life, the EtOH level of the D-fruit $\mathrm{CO}_{2}$-treated at $20{ }^{\circ} \mathrm{C}$ did not change, but the other treatments brought about a lower EtOH content, but no differences among them were observed. 


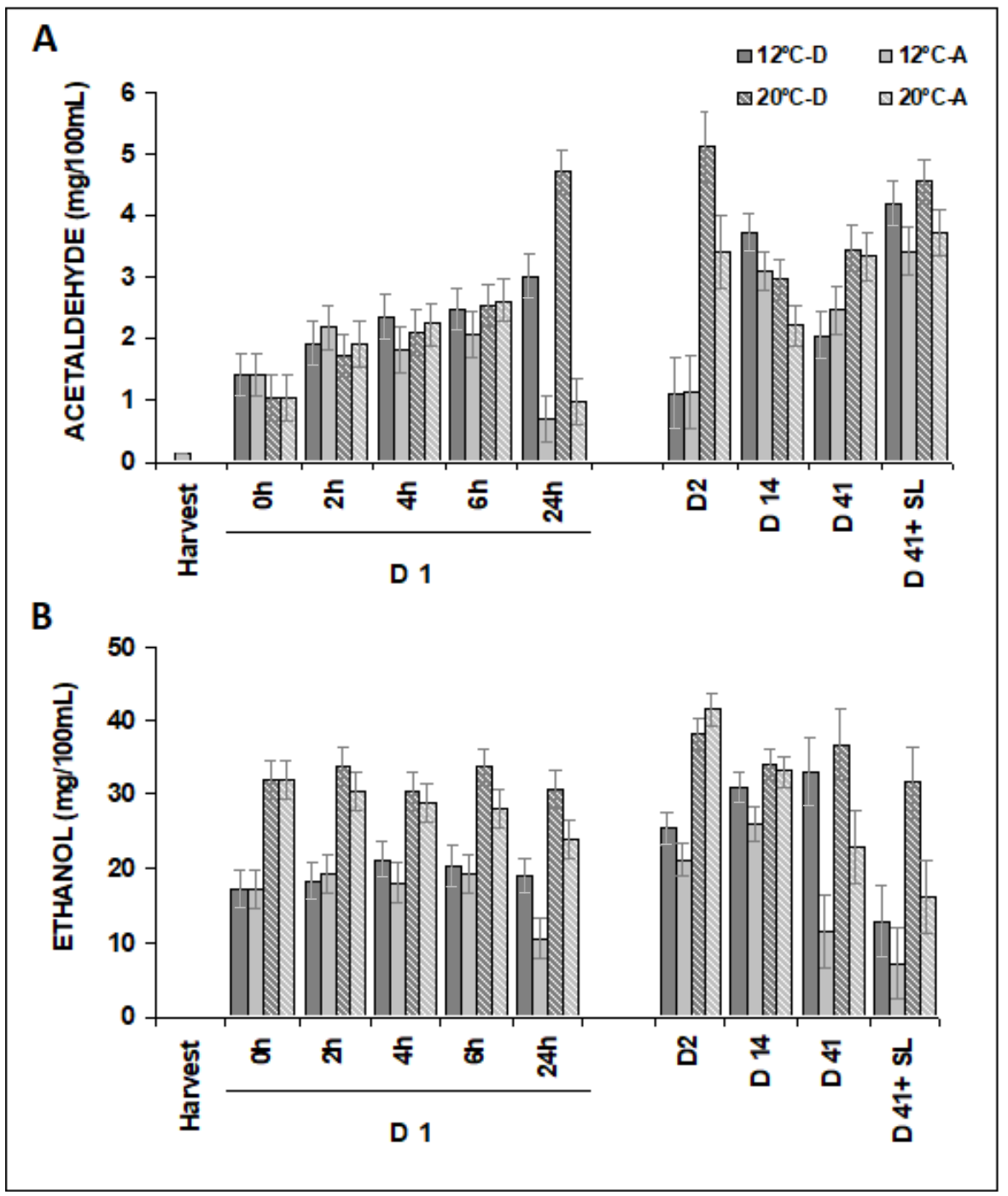

Fig. 5. Acetaldehyde and Ethanol Concentration in Juice. Evolution of the $\mathrm{AcH}(\mathrm{A})$ and EtOH (B) concentration in fruit juice $\left(\mathrm{mg} 100 \mathrm{~mL}^{-1}\right)$ in the persimmon fruit submitted to the $\mathrm{CO}_{2}$ deastringency treatment $\left(95 \% \mathrm{CO}_{2}\right)$ at $12{ }^{\circ} \mathrm{C}$ and $20{ }^{\circ} \mathrm{C}$, and then transferred directly to cold storage at $1{ }^{\circ} \mathrm{C}\left(12{ }^{\circ} \mathrm{C}-\mathrm{D}\right.$ and $\left.20^{\circ} \mathrm{C}-\mathrm{D}\right)$ or attemperated for 24 hours at $20^{\circ} \mathrm{C}\left(12{ }^{\circ} \mathrm{C}-\mathrm{A}\right.$ and $\left.20^{\circ} \mathrm{C}-\mathrm{A}\right)$ before being cold stored for $41 \mathrm{~d}$ at $1{ }^{\circ} \mathrm{C}$, plus a 3 -day shelflife period at $20^{\circ} \mathrm{C}$. Vertical bars represent the LSD intervals $(p=0.05)$. 


\section{4. $\mathrm{CO}_{2}, \mathrm{AcH}$ and $\mathrm{EtOH}$ release}

The release of $\mathrm{CO}_{2}$ from the fruit treated at $12{ }^{\circ} \mathrm{C}$ and $20{ }^{\circ} \mathrm{C}$ is shown in Figure 6. At harvest, fruit had values of $7.2 \mathrm{~mL} \mathrm{~kg}^{-1} \mathrm{~h}^{-1}$. The $\mathrm{CO}_{2}$ deastringency treatment applied at both temperatures led to a drastic increase in $\mathrm{CO}_{2}$ with values above $120 \mathrm{~mL} \mathrm{~kg}^{-1} \mathrm{~h}^{-1}$. These high $\mathrm{CO}_{2}$ values have been associated with the diffusion of the $\mathrm{CO}_{2}$ that had accumulated inside fruit during treatment. That is, once fruit were moved from the $\mathrm{CO}_{2}$ application chamber to an air atmosphere environment, the $\mathrm{CO}_{2}$ detained by fruit was released. This is why the term ' $\mathrm{CO}_{2}$ release' is used in this study rather than ' $\mathrm{CO}_{2}$ production'.

In the fruit treated at $12{ }^{\circ} \mathrm{C}$, slight differences between AT-fruit and D-fruit were detected immediately after treatment $(0 \mathrm{~h})$, with $\mathrm{CO}_{2}$ values of 190 and $150 \mathrm{~mL} \mathrm{~kg}^{-1} \mathrm{~h}^{-1}$, respectively. However, in the fruit treated at $20^{\circ} \mathrm{C}, \mathrm{CO}_{2}$ release was clearly more marked in those submitted to an attemparation period than in those transferred directly to cold storage (230 and $140 \mathrm{~mL}$ $\mathrm{kg}^{-1} \mathrm{~h}^{-1}$, respectively). During the subsequent periods, $\mathrm{CO}_{2}$ release gradually decreased, and the measurements taken until $6 \mathrm{~h}$ showed a greater $\mathrm{CO}_{2}$ release in A-fruit than in those transferred directly to $1^{\circ} \mathrm{C}$.

After $24 \mathrm{~h}$, the $\mathrm{CO}_{2}$ level significantly lowered in all the fruit with values of about $25 \mathrm{~mL} \mathrm{~kg}^{-1} \mathrm{~h}^{-1}$. On Day 2, $\mathrm{CO}_{2}$ release lowered to similar values to those recorded at harvest in all the treatments. During the subsequent storage period, the values remained quite constant, and it was only when fruit were transferred to $20{ }^{\circ} \mathrm{C}$ after $41 \mathrm{~d}$, in order to simulate commercialisation that a slight increase in $\mathrm{CO}_{2}$ was observed, with no noted differences among treatments. 


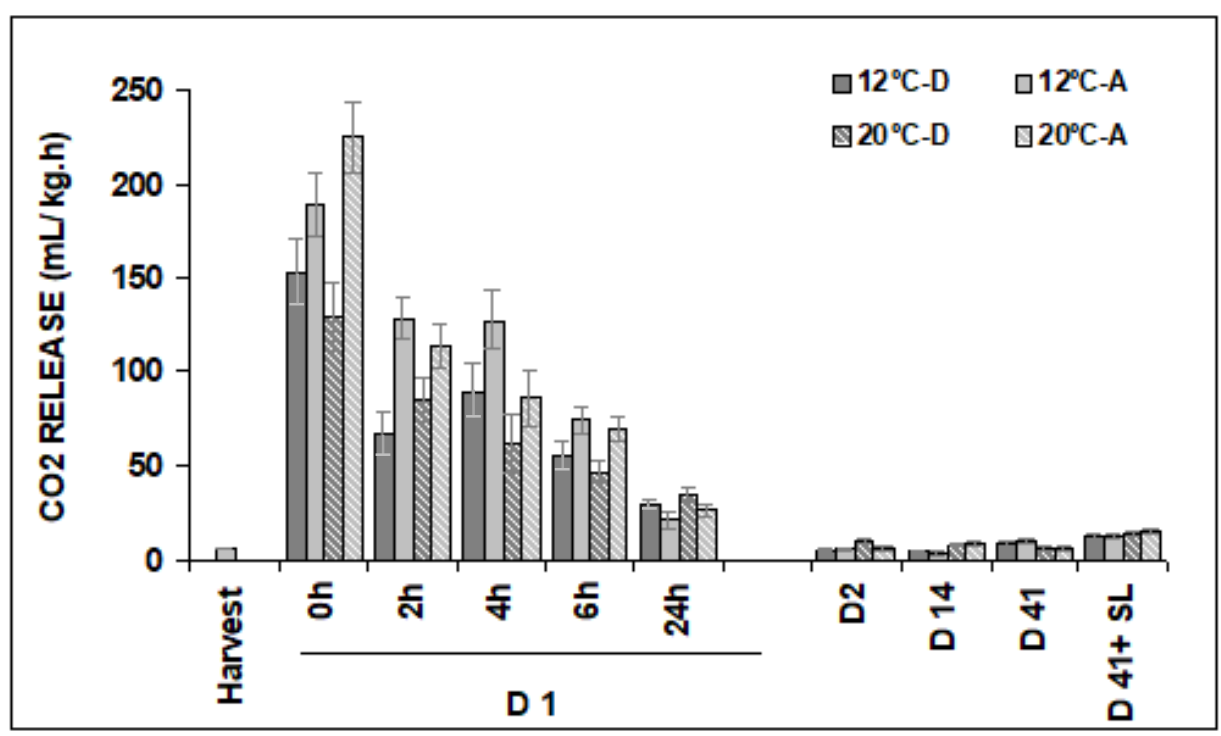

Fig. 6. Evolution of the $\mathrm{CO}_{2}$ release $\left(\mathrm{mL} \mathrm{kg}^{-1} \mathrm{~h}^{-1}\right)$ in the persimmon fruit submitted to the $\mathrm{CO}_{2}$ deastringency treatment $\left(95 \% \mathrm{CO}_{2}\right)$ at $12{ }^{\circ} \mathrm{C}$ and $20{ }^{\circ} \mathrm{C}$, and then trasferred directly to cold storage at $1{ }^{\circ} \mathrm{C}\left(12{ }^{\circ} \mathrm{C}-\mathrm{D}\right.$ and $\left.20^{\circ} \mathrm{C}-\mathrm{D}\right)$ or attemperated for $24 \mathrm{~h}$ at $20^{\circ} \mathrm{C}$ $\left(12{ }^{\circ} \mathrm{C}-\mathrm{A}\right.$ and $20^{\circ} \mathrm{C}$-A) before being cold stored for $41 \mathrm{~d}$ at $1{ }^{\circ} \mathrm{C}$, plus a 3-day shelf-life period at $20^{\circ} \mathrm{C}$. Vertical bars represent the LSD intervals $(p=0.05)$.

As explained for $\mathrm{CO}_{2}$, the $\mathrm{AcH}$ and $\mathrm{EtOH}$ values presented in Figures 7A and 7B correspond to the release of the gases that accumulated inside fruit during the $\mathrm{CO}_{2}$ treatment. During the first $4 \mathrm{~h}$ in the $\mathrm{CO}_{2}$-treated fruit at $20{ }^{\circ} \mathrm{C}$, the release of $\mathrm{AcH}$ and $\mathrm{EtOH}$ was more marked in AT-fruit than in D-fruit. However, in the $\mathrm{CO}_{2}$-treated fruit at $12{ }^{\circ} \mathrm{C}$, no differences between treatments were observed until $6 \mathrm{~h}$. All the fruit showed a marked decrease after $24 \mathrm{~h}$, with no differences among treatments. From this day onwards, the level of these two volatiles dropped in all the fruit. 


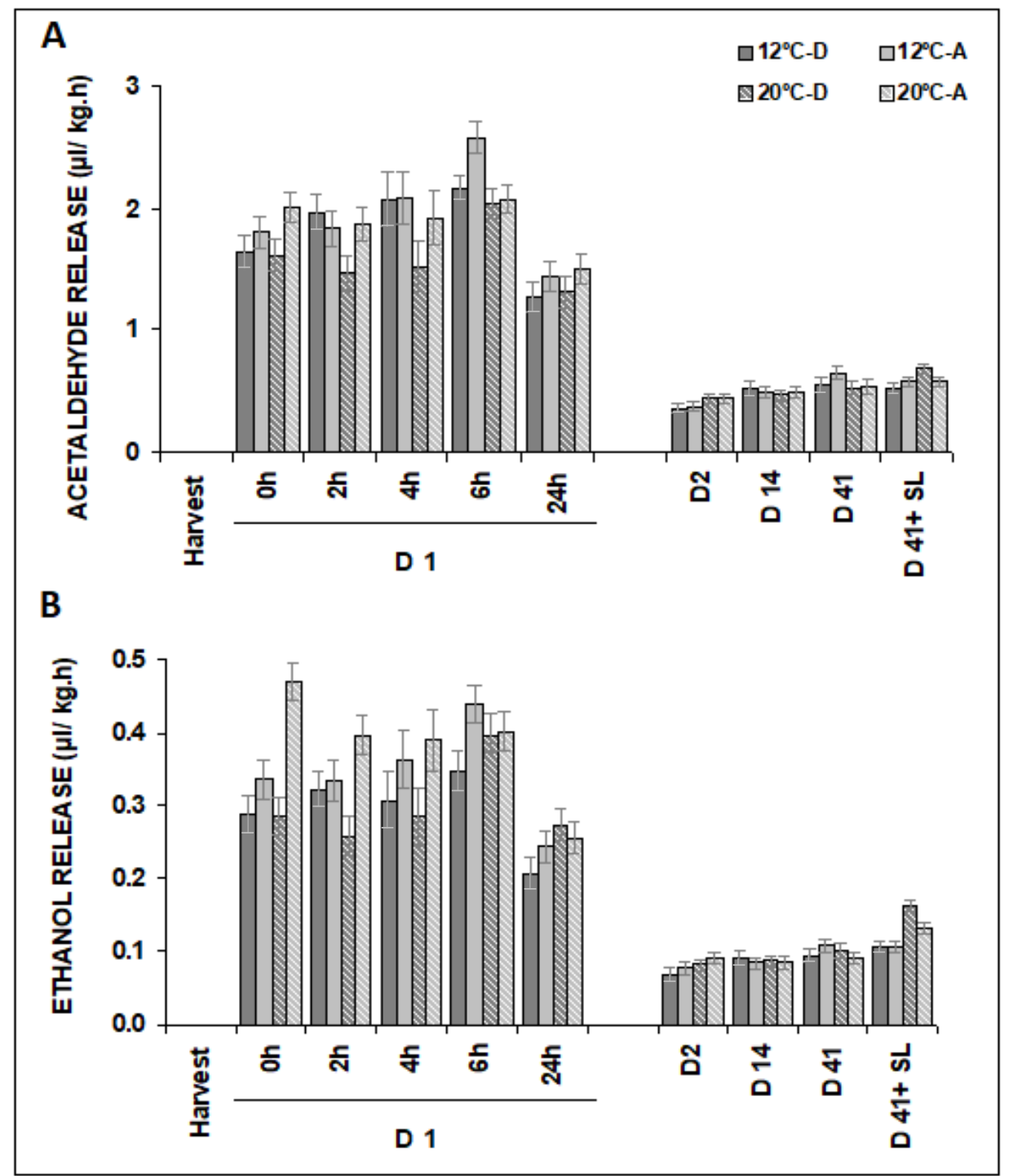

Fig. 7. Acetaldehyde and Ethanol Release. Evolution of the $\mathrm{AcH}(\mathrm{A})$ and $\mathrm{EtOH}(\mathrm{B})$ release $\left(\mu \mathrm{Lg}^{-1} \mathrm{~h}^{-1}\right.$ ) in the persimmon fruit submitted to the $\mathrm{CO}_{2}$ deastringency treatment $\left(95 \% \mathrm{CO}_{2}\right)$ at $12{ }^{\circ} \mathrm{C}$ and $20^{\circ} \mathrm{C}$, and then transferred directly to cold storage at $1{ }^{\circ} \mathrm{C}\left(12{ }^{\circ} \mathrm{C}-\mathrm{D}\right.$ and $\left.20^{\circ} \mathrm{C}-\mathrm{D}\right)$ or attemperated for $24 \mathrm{~h}$ at $20 \mathrm{C}\left(12{ }^{\circ} \mathrm{C}-\mathrm{A}\right.$ and $\left.20^{\circ} \mathrm{C}-\mathrm{A}\right)$ before being cold stored for $41 \mathrm{~d}$ at $1{ }^{\circ} \mathrm{C}$, plus a 3-day shelf-life period at $20^{\circ} \mathrm{C}$. Vertical bars represent the LSD intervals $(p=0.05)$. 


\section{Discussion}

In the present study, the browning index results revealed that only the fruit transferred directly to coldstorage displayed flesh browning after 41 days, indicating that, the attemperation period is a crucial factor to avoid the development of this flesh disorder. According to our results Min et al. (2018) reported browning incidence in 'Niuxin' persimmons transferred directly from $\mathrm{CO}_{2}$ treatment to cold storage chamber while this disorder was not observed in fruit that have been not submitted to the deastringency treatment before storage. More recently, Win et al. (2019) reported browning manifestation after cold storage of 'Sangjudungsi' persimmons previously treated with 1-MCP and $\mathrm{CO}_{2}$. The authors did not describe the conditions between $\mathrm{CO}_{2}$ treatment and fruit transfer to cold storage, but it is quite possible that fruit were transferred directly to cold chambers.

It is well-known that the astringency removal process using $\mathrm{CO}_{2}$ consists in two phases: 1) an induction phase in which fruit must be maintained for a minimum period at high $\mathrm{CO}_{2}$ concentrations. During this phase, $\mathrm{AcH}$ and $\mathrm{EtOH}$ are accumulated as result of the anaerobic respiration and tannins-AcH reaction leads to a tannins insolubilization process; 2 ) a second phase in which astringency keeps gradually disappearing and presence of $\mathrm{CO}_{2}$ is not essential (Gazit \& Adato, 1972). These two phases are temperature-dependent (Matsuo \& Ito, 1977).

Accordingly, our results showed that the tannins insolubilisation reaction that took place immediately after $\mathrm{CO}_{2}$ treatment was faster when the process was performed at $20{ }^{\circ} \mathrm{C}$ than at $12{ }^{\circ} \mathrm{C}$. Moreover, during the first 24 horas after $\mathrm{CO}_{2}$ treatment a clear effect of the temperature exposure on tannins insolubilisation was also observed as the decline in soluble tannins was faster in the fruit kept at $20^{\circ} \mathrm{C}\left(20^{\circ} \mathrm{C}-\mathrm{A}\right.$ and $\left.12{ }^{\circ} \mathrm{C}-\mathrm{A}\right)$ than in those directly moved to cold storage $\left(20^{\circ} \mathrm{C}-\mathrm{D}\right.$ and $\left.12{ }^{\circ} \mathrm{C}-\mathrm{D}\right)$.

It is noteworthy that the $\mathrm{CO}_{2}$ treatment to which fruit were subjected led to not only $\mathrm{AcH}$ and EtOH accumulating in fruit flesh, but also $\mathrm{CO}_{2}$. The ability of the fruit to continue accumulating or releasing these gases during the hours that followed the $\mathrm{CO}_{2}$ treatment was also highly depended on the temperature after treatment. So, maintaining fruit for $24 \mathrm{~h}$ at $20^{\circ} \mathrm{C}$ after being submitted to 
the deastringency treatment resulted in a faster release of these three gases out of the fruit compared to fruit transferred directly to coldstorage. This fact, first described in this study, is explained by the effect of temperature and pressure in the diffusion coefficient of a gas (Welty et al., 1984). Diffusion increases with increasing temperature as molecules move more rapidly, and decreases with increasing pressure, which packs more molecules in a given volume and, thus, makes it harder for them to move.

The lower ability to release $\mathrm{CO}_{2}$ at low temperature led to the anaerobic respiration lasted longer in the fruit transferred directly to low temperature (D-fruit), with the consequent accumulation of $\mathrm{AcH}$, compared with the fruit maintained at $20^{\circ} \mathrm{C}$ (A-fruit). So, this $\mathrm{AcH}$ accumulation in fruit flesh during the first $24 \mathrm{~h}$ after $\mathrm{CO}_{2}$-treatment seems to be the key to browning development in the fruit. Moreover, the browning severity was higher in those fruits $\mathrm{CO}_{2}$ treated at $20{ }^{\circ} \mathrm{C}\left(\mathrm{D}-20{ }^{\circ} \mathrm{C}\right)$, in which the highest $\mathrm{AcH}$ concentrations were detected after $24 \mathrm{~h}$.

The link connecting the accumulation of higher $\mathrm{AcH}$ levels triggered by anoxia situation and flesh browning manifestation that herein was observed in the Dfruit has been previously suggested for other fruit by different authors. So, a situation of anoxia in the central fruit region has been associated with the development of browning disorders in pear (Ho et al., 2010). Moreover, the greater sensitivity of pear to develop internal browning, has been associated with the lesser ability tissues to facilitate gas exchange (Verboten et al., 2008) and as observed herein, $\mathrm{CO}_{2}$ diffusivity in pear has also been reported to be strongly influenced by temperature (Ho et al., 2006).

Moreover, the effect of anoxia to cause unrecoverable cell damage and flesh disorders (Ho et al., 2009) has been related to a smaller amount of detoxification enzymes against harmful reactive oxygen species (ROS) (Drew 1997; Purvis, 2001; Apel \& Hirt, 2004). In such a process, AcH accumulation when fruit are exposed to high $\mathrm{CO}_{2}$ concentrations seems to play an important role in tissue browning and cell death (Fan et al., 2005; Zhan et al., 2015) as it can act a promoter of ROS generation.

In persimmon, a tannins oxidation process by ROS mediated by AcH has been previously linked to other kind of browning disorders associated with 
mechanical damage (Novillo et al., 2014). Therefore, it is possible that the high $\mathrm{AcH}$ concentration herein linked to the 'internal flesh browning' manifestation acts as a source of ROS generation. However, cell membranes should prevent the reaction of ROS and the tannins allocated in the vacuole of the so-called 'tannins cells' (Gottreich \& Blumenfeld, 1991; Yonemori et al., 1997). In this sense, the main structural changes that 'Rojo Brillante' undergo during cold storage have been described as loss of cell wall integrity and low intercellular adhesion (Pérez-Munera et al., 2009). This would explain why a relatively long storage period, lasting some $40 \mathrm{~d}$, is necessary for internal flesh browning to be manifested. Only after cell membranes lose their integrity due to low temperature conditions can the ROS generated by $\mathrm{AcH}$ mediation oxidise tannins with the subsequent browning manifestation. While high $\mathrm{AcH}$ concentration accumulated in flesh at the beginning of storage seems to be the primary cause of browning disorder, an $\mathrm{EtOH}$ accumulation was detected during browning manifestation. Similarly, the EtOH concentration has been suggested as a potential predictor of the flesh browning manifestation risk during prolonged apple fruit storage as it has been associated with flesh browning induced by heat stress (Fan et al., 2005).

In summary the results obtained in this study revealed for the first time that temperature at which the fruit is exposed after $\mathrm{CO}_{2}$ tretament is the main factor implied in 'internal flesh browning' manifested in 'Rojo Brillante' persimmon after cold storage. An attemperation period at $20{ }^{\circ} \mathrm{C}$ during $24 \mathrm{~h}$ after deastringency treatment facilitates the diffusion of $\mathrm{CO}_{2}$ out of fruit, which results in lower $\mathrm{AcH}$ accumulation, which seems to play a key role in preventing browning disorder manifestation. Therefore, in the case that persimmon have to be cold stored, it is necessary to implement an attemperation period after the deastringency treatment to avoid internal browning manifestation.

\section{Acknowledgements}

This study has been supported by the Instituto Nacional de Tecnología Agraria y Alimentaria de España (INIA) through the projects RTA 2013-00043-C02-01 and RTA2017-00045-C02-01 with the support of FEDER funds. In addition, it 
has been supported by the Valencian Institute for Agricultural Research (Project $\mathrm{N}^{\circ}$ 51910).

\section{References}

Apel, K., \& Hirt, H. (2004). Reactive oxygen species: metabolism, oxidative stress, and signal transduction. Annual Review of Plant Biology. 55, 373399. https://doi.org/10.1146/annurev.arplant.55.031903.141701

Besada, C., Arnal, L., \& Salvador, A. (2008). Improving storability of persimmon cv. Rojo Brillante by combined use of preharvest and postharvest treatments. Postharvest Biology and Technology. 50, 169 - 175. https://doi.org/10.1016/j.postharvbio.2008.05.013

Besada, C., Arnal, L., Salvador, A., \& Martínez-Jávega, J. M. (2010). Optimization of the duration of deastringency treatment depending on persimmon maturity. Acta Horticulturae. 858, 69 - 74. https://doi.org/10.17660/actahortic.2010.858.7

Besada, C., Gil, R., Bonet, L., Quiñones, A., Intrigliolo, D., \& Salvador, A. (2016). Chloride stress triggers maturation and negatively affects the postharvest quality of persimmon fruit. Involvement of calyx ethylene production. Plant Physiology and Biochemistry. 100, 105-112. https://doi.org/10.1016/j.plaphy.2016.01.006

Drew, M.C. (1997). Oxygen deficiency and root metabolism: injury and acclimation under hypoxia and anoxia. Annual Review of Plant Physiology and Plant Molecular Biology. 48, 223-250. https://doi.org/10.1146/annurev.arplant.48.1.223

Fan, L., Song, J., Forney, C., \& Jordan, A. (2005). Ethanol production and chlorophyll fluorescence predict breakdown of heat-stressed apple fruit during cold storage. Journal of the American Society. 130(2), 237-243. https://doi.org/10.21273/jashs.130.2.237 
Gazit, S., \& Adato, I. (1972). Effect of carbon dioxide atmosphere on the course of astringency disappearance of persimmon fruits (Diospyros Kaki L.). Journal of Food Science. 37, 815-817. https://doi.org/10.1111/j.13652621.1972.tb03676.x

Gottreich, M., \& Blumenfeld, A. (1991). Light microscopic observations of tannin cell walls in persimmon fruit. Journal of Horticultural Science. 66, 731-736. https://doi.org/10.1080/00221589.1991.11516205

Ho, Q.T., Verlinden, B.E., Verboven, P., Vandewalle, S., \& Nicolai, B.M. (2006). A permeation-diffusion-reaction model of gas transport incellular tissue of plant material. Journal of Experimental Botany. 57, 4215-4224. https://doi.org/10.1093/jxb/erl198

Ho, Q.T., Verboven, P., Mebatsion, H.K., Verlinden, B.E., Vandewalle, S., \& Nicolai, B.M. (2009). Microscale mechanisms of gas exchange in fruit tissue. New Phytologist. 182, 163-174. https://doi.org/10.1111/j.14698137.2008.02732.x

Ho, Q.T., Verboven, P., Verlinden, B.E., \& Nicolai, B.M. (2010). A model for gas transport in pear fruit at multiple scales. Journal of Experimental Botany. 61, 2071-2081. https://doi.org/10.1093/jxb/erq026

Khademi, O., Salvador, A., Zamani, Z., \& Besada, C. (2013). Effects of hot water treatments antioxidant enzymatic system in reducing flesh browning of persimmon. Food and Bioprocess Technology. 6, 3038-3046. https://doi.org/10.1007/s11947-012-0959-6

Matsuo, T., \& Ito S. (1977). On mechanisms of removing astringency in persimmon fruits by carbon dioxide treatment I. Some properties of the two processes in the de-astringency. Plant and Cell Physiology. 18, 17-25. https://doi.org/10.1093/oxfordjournals.pcp.a075409

Min, D., Dong, L., Shu, P., Cui, X., Zhang, X., \& Li, F. (2018). The application of carbon dioxide and 1-methylcyclopropene to maintain fruit quality of 
'Niuxin' persimmon during storage. Scientia Horticulturae. 229, 201-206. https://doi.org/10.1016/j.scienta.2017.11.012

Novillo, P., Salvador, A., Navarro, P., \& Besada, C. (2015). Involvement of the redox system in chilling injury and its alleviation by 1-Methylcyclopropene in 'Rojo Brillante' persimmon. HortScience. 50,570-576. https://doi.org/10.21273/HORTSCI.50.4.570

Novillo, P., Salvador, A., Llorca, E., Hernando, I., \& Besada, C. (2014). Effect of $\mathrm{CO} 2$ deastringency treatment on flesh disorders induced by mechanical damage in persimmon. Biochemical and Microstructural Studies. Food Chemistry. 145 , 453-463. https://doi.org/10.1016/j.foodchem.2013.08.054

Pérez-Munuera, I., Hernando, I., Larrea, V., Besada, C., Arnal, L., \& Salvador, A. (2009). Microstructural study of chilling injury alleviation by 1methylcyclopropene in persimmon. HortScience. 44, $742-745$. https://doi.org/10.21273/hortsci.44.3.742

Purvis, AC. (2001). Reduction of superoxise production by mitochondria oxidizing NADH in the presence of organic acids. Journal of Plant Physiology. 158, 159-165. https://doi.org/10.1078/0176-1617-00128

Salvador, A., Arnal, L., Monterde, A., \& Cuquerella, J. (2004). Reduction of chilling injury symptoms in persimmon fruit $\mathrm{cv}$. Rojo Brillante by 1-MCP. Postharvest Biology and Technology. 33, 285-291. https://doi.org/10.1016/j.postharvbio.2004.03.005

Salvador, A., Arnal, L., Besada, C., Larrea, V., Quiles, A., \& Pérez-Munuera, I. (2007). Physiological and structural changes during ripening and deastringency treatment of persimmon fruit cv. 'Rojo Brillante'. Postharvest Biology and Technology. 46, 181-188. https://doi.org/10.1016/j.postharvbio.2007.05.003 
Taira, S. 1996. Astringency in persimmon, in: Linskens, H.F., Jackson J.F.(Eds.). Fruit Analysis. Springer, Germany, pp. 97-110. https://doi.org/10.1007/978-3-642-79660-9_6

Verboven, P., Kerckhofs, G., Mebatsion, H.K., Ho, Q.T., Temst, K., Wevers, M., \& Cloetens, P., Nicolai, B.M. (2008). Three-dimensional gas exchange pathways in pome fruit characterized by synchrotron X-ray computed tomography. Plant Physiology. 147, 518-527. https://doi.org/10.1104/pp.108.118935

Welty, J.R., Wicks, C.E., \& Wilson, R.E. (1984). Fundamentals of Momentum, Heat, and Mass Transfer. John Wiley \& Sons, New York.

Win, N.M., Yoo, J., Lee, J., Jung, H.Y., \& Kang, I.K. (2019). Effect of Different $\mathrm{CO} 2$ deastringency application timing on fruit quality attributes and physiological disorders in cold-stored 'Sangjudungsi' persimmon fruit. Horticultural Science and Technology. 37, 395-403. https://doi.org/10.7235/HORT.20190040

Yonemori, K., Oshida, M., \& Sugiura, A. (1997). Fine structure of tannin cells in fruit and callus tissues of persimmon. Acta Horticulturae. 436, 403-416. https://doi.org/10.17660/actahortic.1997.436.43

Zhang, S., \& Bing Deng, Y.S. (2015). Exogenous carbon monoxide treatment delayed the ethanol metabolism and fruit softening of postharvest jujube. Asian Journal of Agricultural and Food Sciences. 3(2), 196-204. 


\title{
CHAPTER II
}

\section{Application of a new wax containing ethanol as a method to remove persimmon astringency during cold storage}

\begin{abstract}
Ayoub Fathi Najafabadia , Cristina Besada , Rebeca Gila , Daniel Tormo ${ }^{b}$, Pilar Navarro ${ }^{a}$, Alejandra Salvador ${ }^{a}$
\end{abstract}

${ }^{a}$ Centro de Tecnología Postcosecha del Instituto Valenciano de Investigaciones Agrarias (IVIA), Carretera Moncada-Náquera, Km. 4.5, 46113, Moncada, Valencia, Spain

${ }^{b}$ Fomesa Fruitech S.L.U., 46469, Beniparrell, Valencia, Spain

Reference: Journal of Food Science and Technology, 2021. https://doi.org/10.1007/s13197-021-05011-w 



\begin{abstract}
Nowadays the treatment based on applying high $\mathrm{CO}_{2}$ concentrations to fruit is the main method used in astringent persimmon prior to being commercialized, but it can cause quality problems for fruit during cold storage. The aim of this study was to evaluate the effectiveness of a recently patented astringency removal method based on applying a new wax whose formulation includes ethanol before commercial packaging. During two seasons, three treatments were evaluated in cv. Rojo Brillante and Triumph: 1) $\mathrm{CO}_{2}$-standard treatment; 2) waxed and packed in plastic film according to the patented method; 3 ) packed in plastic film without any treatment. During a third season, the new method's effectiveness in removing astringency was evaluated under industrial conditions. After treatments fruit was stored at $0{ }^{\circ} \mathrm{C}$ for 15,21 and 30 days before being transferred at $20{ }^{\circ} \mathrm{C}$ to simulate a 5-days shelf-life. All the fruit treated with the new wax completely lost astringency after 30 days at $0{ }^{\circ} \mathrm{C}$, and commercial firmness was maintained. At the end of the storage, fruit quality was substantially higher in fruit submitted to the new treatment. $\mathrm{CO}_{2}$-treated fruit, manifested internal browning after 30 storage days and shelf-life, while this disorder was not detected in waxed fruit.
\end{abstract}

Keywords: deastringency, cold storage, wax, ethanol, 'Rojo Brillante', 'Triumph' 


\section{Introduction}

Persimmon cultivars are divided into two categories, astringent and nonastringent, depending on their astringency level at harvest. Astringent persimmons are not edible when harvested due to the presence of high soluble tannin concentrations, which produce a dry puckering sensation in the mouth (Besada \& Salvador 2018). 'Triumph' and 'Rojo Brillante' are the main cultivars from the Mediterranean region, both of which are astringent at harvest.

The most habitual treatment used to remove astringency in persimmon is based on exposing fruit to $95-98 \% \mathrm{CO}_{2}$ at $20{ }^{\circ} \mathrm{C}$ and $90 \% \mathrm{RH}$ for $24 \mathrm{~h}$ (Besada \& Salvador 2018). The effectiveness of this method lies in the fact that it triggers anaerobic respiration in fruit, which gives rise to the accumulation of acetaldehyde. The reaction between this acetaldehyde and the soluble tannins responsible for astringency leads tannins to become insoluble, hence they lose their astringent character (Arnal \& Del Río 2003; Salvador et al. 2007). Although the effectiveness of this deastringency method has been widely studied, a high $\mathrm{CO}_{2}$ concentration affects the parenchyma structure, causing cell membrane degradation, which can lead to loss of flesh firmness after treatment. Thus, in the case the fruit has to be cold stored, it is recommended to remove the astringency after conservation to preserve the fruit firmness. Nevertheless, it is noteworthy that in some marketing scenarios, such as shipments to overseas countries, $\mathrm{CO}_{2}$ treatment is necessarily applied before using refrigerated transport. Under these conditions, the risk of fruit quality loss during cold storage is high. Indeed, the fruit softening and internal browning that appears during prolonged refrigerated transport is one of the most important problems that is limiting the market to overseas countries.

In this context, interest has been shown in finding alternative deastringency methods that can be applied in cold storage management scenarios to avoid quality losses associated with the currently employed $\mathrm{CO}_{2}$ treatment. To respond to this demand, the present work takes as a starting point two postharvest technologies used for different purposes that have never been combined. On the one hand, it is known that exposing fruit to ethanol has an effect of removing astringency. Ethanol vapor was one of the first treatments 
to be assayed to remove astringency in the persimmon fruit industry (Taira et al. 1989). Although this treatment still continues to be used in countries like Brazil (Tessmer et al. 2018), it is being replaced with $\mathrm{CO}_{2}$ treatment as the latter requires less time to remove astringency and fruit firmness is better preserved.

On the other hand, edible waxes are used to carry some ingredients like antioxidants, antifungal and antimicrobial agents for different purposes in different fruits (Nair et al. 2018; Rojas-Graü et al. 2007). In persimmon no information on this regard exits, only some studies have reported the use of waxes to reduce softening and weight loss (Blume et al. 2008; Carvalho da Silva et al. 2011).

In this context, the hypothesis based on producing an edible wax as a carrier for ethanol was the starting point to reach research collaboration between the Instituto Valenciano de Investigaciones Agrarias (IVIA) and the Fomesa Fruitech S.L.U. Company. The final objective was to find a new deastringency method based on ethanol that can be easily applied and that does not have negative effects on the fruit quality during low-temperature storage and subsequent shelf-life. The studies carried out allowed to develop an ethanolic wax that could remove fruit astringency during cold storage when combined with fruit packaging, and this process has been recently patented (P-101459).

The objective of this work was to evaluate the effectiveness of this new method to remove persimmon astringency during cold storage, and to determine its effect on other important physico-chemical quality parameters as color, firmness, total soluble solids, chilling injury and browning incidence. This study was part of the studies submitted for approval of the patent.

\section{Materials and Methods}

\subsection{Fruit source and treatments}

This study was conducted in three consecutive seasons from 2017 to 2019. In the first and second season the treatments were tested under lab conditions 
while in the third season the assays were carried out under industrial conditions.

First season (S1). 'Rojo Brillante' persimmons were harvested in November in a commercial maturity stage from an orchard in Valencia (Spain) before being immediately transported to the IVIA's Postharvest Laboratory Technology Center. Fruit were carefully selected for their uniform size and external color. Then they were separated into homogenous lots of 12 fruits and were placed on plastic alveoli trays in a cardboard fruit box. Three of these lots were used to evaluate the physico-chemical quality of fruit at harvest.

The remaining lots of fruit were subjected to the following three treatments (12 lots per treatment):

1) fruit submitted to the traditional $\mathrm{CO}_{2}$ treatment with $95 \% \mathrm{CO}_{2}$ at $20{ }^{\circ} \mathrm{C}$ for 24 $\mathrm{h}\left(\mathrm{CO}_{2}\right)$;

2) fruit waxed and packed in plastic film according to the patented method (Wax+Film);

3) fruit packed in plastic film with no wax application, used as the control (Film).

After applying treatments, all the fruit were stored at $0{ }^{\circ} \mathrm{C}$ with $85 \%-90 \% \mathrm{RH}$ for up to 30 days. Periodically after 15, 21 and 30 days, three lots of each treatment were removed from cold storage for analysis. In addition, after 30 days three other lots of fruit were transferred to $20^{\circ} \mathrm{C}$ for 5 days to simulate the shelf-life period, after which they were evaluated.

Second season (S2). During this season, experiments were carried out in the same way as during the first season, but in this case they were performed with persimmons 'Rojo Brillante' and 'Triumph'. The fruit of both cultivars were harvested in the commercial maturity stage in December from two orchards in Valencia. During this season, a 5-day shelf-life at $20^{\circ} \mathrm{C}$ was simulated after 15 , 21 and 30 days of cold storage periods.

Third season (S3). During this season, the effectiveness of the new method to remove astringency was evaluated under industrial conditions with 'Rojo Brillante'. To this end, after harvest fruit were transported to a commercial 
packing house (Natural Hand S.L.) where they were carefully selected for their uniform size and external color. Then fruit were separated into homogenous lots of 16 fruits and were placed on plastic alveoli trays in a commercial cardboard fruit box. Four treatments were assayed: 1) fruit submitted to the traditional $\mathrm{CO}_{2}$ treatment with $95 \% \mathrm{CO}_{2}$ at $20{ }^{\circ} \mathrm{C}$ for $24 \mathrm{~h}\left(\mathrm{CO}_{2}\right)$ in industrial chambers; 2 ) fruit waxed and packed in plastic bags according to the patented method (Wax+Film); 3) fruit packed in plastic films with no wax application, used as the control (Film); 4) fruit waxed and boxes stacked on a wooden pallet, strapped with macroperforated stretch film by a commercial automatic strapping machine (Wax+Pallet). Here the objective was to generate a kind of film package by strapping pallets, whereby a cardboard sheet was placed on top of the pallet (Wax+ Pallet) and it was film-strapped until almost the whole pallet surface was covered. After applying treatments, boxes were placed in the cold chambers at the Natural Hand Company at $0-1{ }^{\circ} \mathrm{C}$ with $85 \%-90 \% \mathrm{RH}$ for up to 30 days. After 30 days, three lots of each treatment were evaluated. Three other lots of fruit were transferred to $20{ }^{\circ} \mathrm{C}$ for 5 days to simulate the shelf-life period, after which they were evaluated.

In all cases after harvest the fruit were treated with 1-MCP under commercial conditions (500 nL/L $\mathrm{L}^{-1}$ of $1-\mathrm{MCP}$ for $24 \mathrm{~h}$ at room $\mathrm{T}$ ). This treatment is commercially applied to persimmons before they are submitted to low temperature in order to delay chilling injury symptoms (Salvador et al. 2004).

$\mathrm{CO}_{2}$ treatment was carried out in closed containers (467 L), which contained $95 \% \mathrm{CO}_{2}$ for $24 \mathrm{~h}$ at $20{ }^{\circ} \mathrm{C}$ and $90 \% \mathrm{RH}$. These conditions were established by passing a stream of air containing $95 \% \mathrm{CO}_{2}$ through containers.

In the first and second season, in the lab, wax was applied uniformly to the fruit surface with a sprayer at a rate of $12.5 \mathrm{~mL}$ wax per $\mathrm{kg}$ of fruit. Wax and plastic film (Xtend ${ }^{\circledR}$, StePac L.A. Ltd) were provided by the Fomesa Fruitech S.L.U. The application system for the wax in the industry (third season) was composed of two main parts, the pressurizer pump and the spraying gun. The main objective of this application system was to create a fine nebulization of the wax, creating a thin coating of the product on the surface of the fruit. The pressurizer pump is in charge of using pressured air from a compressor to pressurize the wax through an $8 \mathrm{~mm}$ pipe to the spraying guns. Once the wax is 
pressured, the spraying guns are able to make a fine nebulization of the wax on the surface of the fruit. Regarding the spraying gun, we used an $80^{\circ} \mathrm{R}$ nozzle, which allows us to make a diffusion of the wax at an $80^{\circ}$ opening angle and a flow rate of 2.5 gallons per hour.

At harvest, and after different cold storage periods as well as the shelf-life, the determined physico-chemical and sensory parameters were as follows: external color, firmness, soluble tannins content (ST), sensory astringency and off-flavors, acetaldehyde ( $\mathrm{ACH})$ and ethanol $(\mathrm{EtOH})$ in juice. After cold storage, the $\mathrm{CO}_{2}$ and EtOH concentrations inside plastic films were measured.

For a better understanding, the treatments and conditions tested in each season are shown in the table 1.

Table 1. Treatments and conditions tested for 'Rojo Brillante' and Triumph' in the three season studied

\begin{tabular}{|c|c|c|c|c|c|c|c|c|}
\hline \multirow[t]{2}{*}{ Season } & \multirow[t]{2}{*}{ Treatments } & \multirow[t]{2}{*}{ Cultivar } & \multicolumn{3}{|c|}{$\begin{array}{c}\text { Cold storage (CS) } \\
\left(0^{\circ} \mathrm{C}\right)\end{array}$} & \multicolumn{3}{|c|}{$\begin{array}{c}\text { Shelf-life } \\
\text { ( } 5 \mathrm{~d} \text { at } 20^{\circ} \mathrm{C} \text { after } \mathrm{CS} \text { ) }\end{array}$} \\
\hline & & & $15 d$ & $21 d$ & $30 d$ & $15 d$ & $21 d$ & $30 \mathrm{~d}$ \\
\hline S1 & $\begin{array}{c}\mathrm{CO}_{2} \\
\text { Wax+Film } \\
\text { Film }\end{array}$ & Rojo Brillante & $x$ & $x$ & $x$ & - & - & $x$ \\
\hline S2 & $\begin{array}{c}\mathrm{CO}_{2} \\
\text { Wax+Film } \\
\text { Film }\end{array}$ & $\begin{array}{l}\text { Rojo Brillante } \\
\text { Triumph }\end{array}$ & $x$ & $\mathrm{x}$ & $\mathrm{x}$ & $x$ & $\mathrm{x}$ & $\mathrm{X}$ \\
\hline S3 & $\begin{array}{c}\mathrm{CO}_{2} \\
\text { Wax+Film } \\
\text { Film } \\
\text { Wax+Pallet }\end{array}$ & Rojo Brillante & - & - & $\mathrm{x}$ & - & - & $x$ \\
\hline
\end{tabular}

\subsection{Fruit quality assessments}

Determinations were made with 12 fruits, three replicates per treatment. After the low-temperature storage periods and the subsequent shelf-life, the following were evaluated: external color, flesh firmness, soluble tannin contents (ST), sensory astringency and off-flavors, internal and external disorders, $\mathrm{AcH}$ and $\mathrm{EtOH}$ in juice, $\mathrm{EtOH}$ and $\mathrm{CO}_{2}$ in plastic bags. 
Skin color was determined by a Minolta colorimeter (Model CR-300; Minolta, Ramsey, NY). Hunter parameters "L," "a," and "b," were measured and the results were expressed as Color Index $=(1000 \mathrm{a}) /($ Lb) (Salvador et al. 2007). Two measurements were taken on the opposite equatorial area of each fruit.

Flesh firmness was evaluated by a texturometer (model 4301, Instron Corp., Canton, Mass., USA) using an 8-mm plunger. The crosshead speed during firmness testing was set at $10 \mathrm{~mm} / \mathrm{min}$. The results were expressed as load in Newton $(\mathrm{N})$ to break flesh at two equidistant locations in the equatorial region of each fruit after epicarp removal.

Immediately after taking the firmness measurements, fruits were cut into half and any internal disorder was evaluated. The incidence of external and internal disorders was evaluated visually on all the fruit in each lot according to Khademi et al. (2013). Skin browning severity was evaluated on four scales as: 0 , no browning; 1 , slight browning; 2 , moderate browning; 3 , severe browning. Similarly, flesh browning was rated on a 4-point scale according to the browning intensity detected in the central fruit part as: 0 , no browning; 1 , slight browning (less than $30 \%$ of the fruit flesh surface was brown); 2 , moderate browning (more than $30 \%$ and less than $60 \%$ of the fruit flesh surface was brown); 3 , severe browning (more than $60 \%$ of the fruit flesh surface was brown). The browning index (BI) was calculated as:

$\mathrm{BI}=\sum[$ (browning severity) $X$ (no. of fruit at each browning severity) $] / 3 \times$ total no. of fruit.

After disorders evaluation, six fruits per lot were cut to obtain four quarters. Two opposite quarters were frozen at $-21{ }^{\circ} \mathrm{C}$ until the ST analyses. ST content was evaluated by the Folin-Denis method described by Arnal \& Del Río (2004). The results were expressed as a percentage or $\mathrm{g} / 100 \mathrm{~g} \mathrm{FW}$. One of the remaining quarters was used in the sensory evaluation and the other was employed to obtain juice for the $\mathrm{AcH}$ and $\mathrm{EtOH}$ determinations.

The sensory evaluation was performed by 8 trained panelists who were asked to evaluate astringency levels and the presence of off-flavors. Sensory sessions were carried out in a specifically adapted room, where panelists were seated in individual evaluation booths. Fruits were peeled and sliced (longitudinal slices, 
$1.5 \mathrm{~cm}$ wide), and three slices from three different fruits were presented per sample to compensate for variability. Water was provided to cleanse palates between samples. Samples were served in random order to the panelists in 50$\mathrm{mL}$ stainless steel soufflé cups, identified by a unique three-digit number. Each fruit was tasted by at least three panelists. A 5-point scale was used for the sensory astringency evaluation: 1 = no astringency; 2 = residual astringency; 3 = slight astringency; $4=$ moderate astringency; 5 = astringency. $A$ value below 1.5 guarantees the non-astringency of the fruit, and therefore is considered commercially acceptable (Besada et al., 2016; Munera et al., 2017). Off-flavors were evaluated as Presence/Absence.

In order to determine the $\mathrm{AcH}$ and EtOH concentrations, one quarter of the six fruits per lot was placed in an electric juice extractor (model 753, Moulinex, Spain) and the obtained juice was filtered through cheesecloth. AcH and EtOH production was measured with three samples per replicate of juice samples, obtained as previously mentioned and analyzed by headspace gas chromatography. Five milliliters of the filtered juice were transferred to $10-\mathrm{mL}$ vials with crimp-top caps, sealed with TFE/silicone septa, and frozen $\left(-21{ }^{\circ} \mathrm{C}\right)$ until analyzed. For the analysis, samples were put in a water bath at $20^{\circ} \mathrm{C}$ for 1 $\mathrm{h}$, followed by heating at $60{ }^{\circ} \mathrm{C}$ for $10 \mathrm{~min}$. A 1-mL headspace sample was withdrawn from the vials and injected into the gas chromatograph (model 2000, Perkin-Elmer, Norwalk, Conn., USA), equipped with a flame ionization detector (FID) and a $0.32 \mathrm{~cm} \times 1.2 \mathrm{~m}$ Poropak QS 80/100 column. The injector was set at $175^{\circ} \mathrm{C}$. EtOH and $\mathrm{AcH}$ were identified by comparing the retention times with those of a standard solution. The results were expressed as $\mathrm{mg} / 100$ $\mathrm{mL}$.

Prior to opening the plastic bags, the $\mathrm{EtOH}$ and $\mathrm{CO}_{2}$ concentrations were determined. For this purpose, a BD Plasticpak syringe was placed inside the plastic bag and $1 \mathrm{~mL}$ of the generated atmosphere was extracted carefully so as not to damage fruit. This volume was injected into the gas chromatograph (model 2000, Perkin-Elmer, Norwalk, Conn., USA) and the same previously explained pattern was followed. For EtOH, the results were shown as $\mu \mathrm{L} / \mathrm{L}$ and as $\%$ of gas in the atmosphere for $\mathrm{CO}_{2}$. 


\subsection{Statistical Analysis}

Data were subjected to an analysis of variance, based on two factors (treatment $\times$ storage duration). Multiple comparisons between means were determined by the least significant difference test $(P \leq 0.05)$ using the Statgraphics Plus 5.1 software application (Manugistics Inc., Rockville, MD, USA).

\section{Results and discussion}

3.1. Soluble tannins (ST) and sensorial astringency evaluation

At harvest, the ST content in 'Rojo Brillante' was close to 0.65-0.70\% during all three studied seasons (Fig. 1a, 1b, 1d). The ST values for 'Triumph' were slightly higher at harvest time, $0.9 \%$ (second season) (Fig. 1c). These values were in the same range found by most previous studies conducted on both cultivars, which have been related to high astringency levels in fruit (Besada et al. 2014; Novillo et al. 2015; Salvador et al. 2007). 

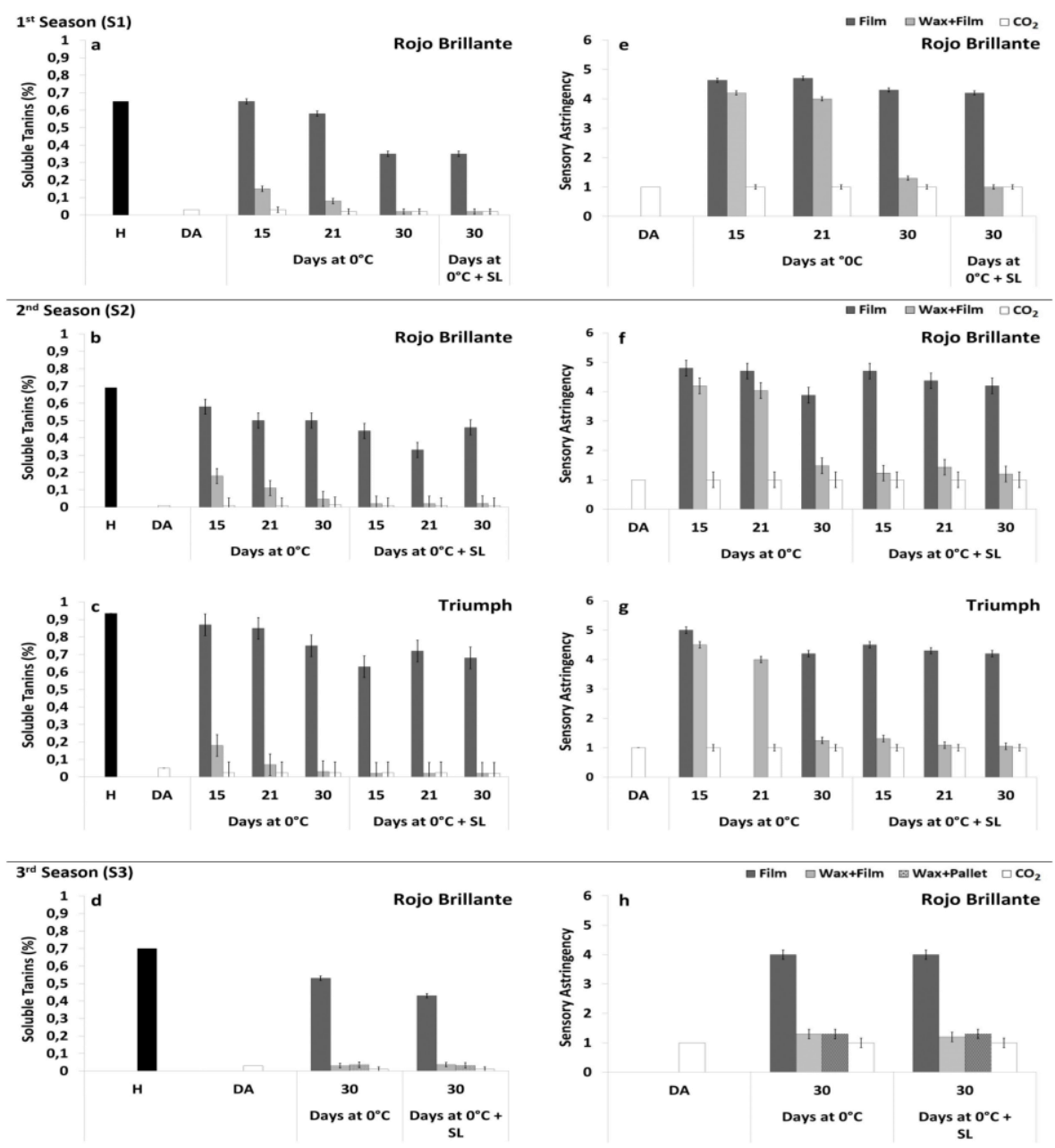

Fig. 1. Soluble tannins content $(a, b, c, d)$ and sensory astringency evaluation $(e, f, g, h)$ of persimmons 'Rojo Brillante' and 'Triumph' at harvest $(\mathrm{H})$ during storage at $0{ }^{\circ} \mathrm{C}$ and after the subsequent 5-day shelf-life period at $20^{\circ} \mathrm{C}$ in season 1 (S1), season 2 (S2) and season 3 (S3). Vertical bars represent LSD intervals ( $p \leq 0.05)$. Sensory astringency evaluation was from 1 = no astringency to 5 = astringency; a value below 1.5 is considered commercially acceptable. Film: fruit packed in plastic film without wax. Wax+Film: fruit waxed and packed in plastic film. $\mathrm{CO}_{2}$ : fruit submitted to $\mathrm{CO}_{2}$ treatment. Wax+Pallet: fruit waxed and boxes stacked on a wooden pallet which was strapped with macroperforated stretch film. DA: 1 day after $\mathrm{CO}_{2}$ treatment. 
As expected, the ST content dropped significantly after being treated with a high $\mathrm{CO}_{2}$ concentration $\left(\mathrm{CO}_{2}\right.$ treatment). In all cases after 1 day of the treatment (DA), the ST concentration lowered to values between $0.01 \%$ and $0.03 \%$. The panelists evaluated fruit astringency with scores of 1 (nonastringent fruit) (Fig. 1e, 1f, 1g, 1h).

In the fruit packed in plastic film with no added wax (Film), ST slightly dropped, over all after 30 cold storage days and the shelf-life that followed the different cold storage periods. Despite of this decrease, in all cases, the ST values remained very high, which resulted in fruit having high levels of sensory astringency (astringency scores ranged between 3.9 and 4.8).

However, the ST in the waxed fruit (Wax+Film) gradually lowered during the studied storage period. In the first and second seasons, after 15 days at low temperature, ST drastically decreased, with values close to $0.15 \%-0.18 \%$ in both cultivars. The sensory evaluation revealed that this fruit still exhibited a high astringency level (scores of 4.2-4.5). In all cases from 15 days onward, the ST content continued to lower and reached values below $0.03 \%$ after 30 days, when the fruit's astringency scores were lower than 1.5, considered to be commercial. Similar results were obtained during the third season, when assays were carried out with 'Rojo Brillante' under industrial conditions. After 30 cold storage days, the wax+film fruit and wax+pallet fruit obtained ST values close to $0.03 \%$. In both cases, fruit was evaluated as non-astringent.

One point worth mentioning is that in the second season, in which the shelflife conditions were simulated after all the cold storage periods, just after 15 and 21 days at low temperature the wax+Film fruit values were $0.01 \%$ and $0.02 \%$ in 'Rojo Brillante' and 'Triumph', respectively, and the panelists did not detect astringency.

In persimmon fruit the threshold of ST leading to astringency perception depends on the cultivar. ST above $0.1 \%$ has been found to confer an astringent taste, and these fruit are not edible in persimmons 'Kaki Tipo', 'Lycopersicom' and 'Thiene' (Vidrih et al. 1994). In the present study, and irrespectively of the treatment to which fruit was submitted, the panelists' evaluation of fruit not being astringent corresponded to the fruit that had an ST content below 
$0.03 \%$. This value agrees with those previously reported for both 'Rojo Brillante' and 'Triumph' (Besada et al. 2010; 2014; Salvador et al. 2007).

\subsection{Acetaldehyde (AcH) and ethanol (EtOH)}

Most methods performed to remove persimmon astringency are based on maintaining fruit under anaerobic conditions or exposing them to products that induce anaerobic respiration. Under these conditions, soluble tannins, responsible for astringency, are polymerized by $\mathrm{AcH}$ that accumulates in flesh, hence the deastringency process rate has been positively related to the level of AcH that accumulates in fruit flesh (Pesis et al. 1988; Taira et al. 1989). In 'Rojo Brillante', the accumulated $\mathrm{AcH}$ concentration after different deastringency treatments has also been closely associated with a drop into the decrease of ST (Besada et al. 2010). Nevertheless, the AcH level required to insolubilize tannins in fruit flesh to reach undetectable astringency values has not yet been established.

In the present study, both cultivars exhibited very low $\mathrm{AcH}$ concentrations at harvest, between 0.1 and $0.3 \mathrm{mg} / 100 \mathrm{~mL}$ (Fig. 2a, 2b, 2c, 2d). These values are in the range reported in previous studies (Arnal \& Del Río 2003; 2004; Besada et al. 2014). As expected in the $\mathrm{CO}_{2}$-treated fruit, $\mathrm{AcH}$ significantly increased 1 day after treatment (DA), with values of around $4.5 \mathrm{mg} / 100 \mathrm{~mL}$ in both cultivars in the first and second seasons. For the third season, the values reached after $\mathrm{CO}_{2}$ treatment were slightly lower, $3.5 \mathrm{mg} \mathrm{AcH} / 100 \mathrm{~mL}$. For all three seasons, $\mathrm{AcH}$ levels linked to $\mathrm{CO}_{2}$-treated fruit showed no relevant changes throughout the study period. 


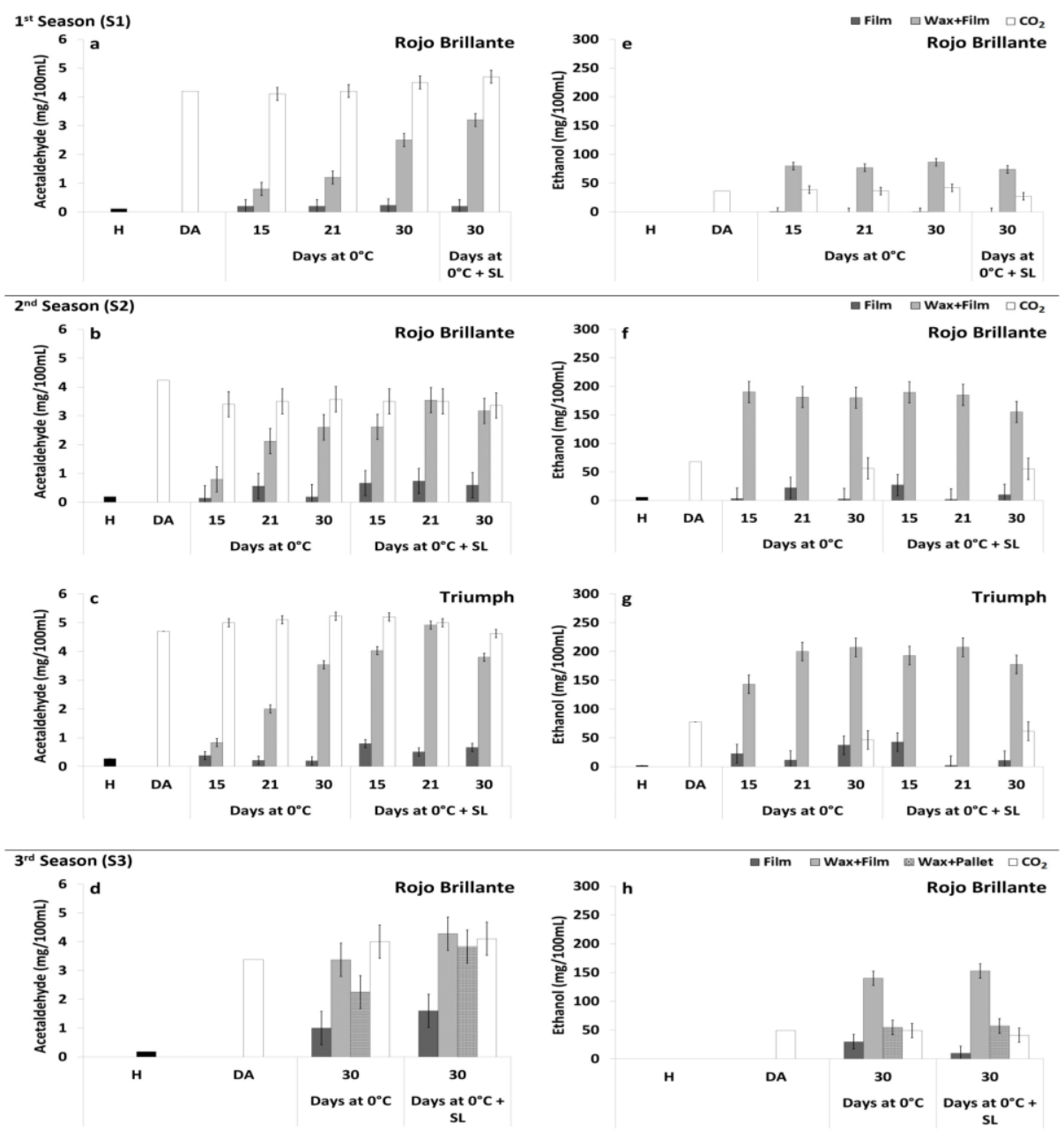

Fig. 2. Acetaldehyde $(a, b, c, d)$ and ethanol $(e, f, g, h)(m g / 100 \mathrm{~mL})$ of persimmons 'Rojo Brillante' and 'Triumph' at harvest $(\mathrm{H})$, during storage at $0{ }^{\circ} \mathrm{C}$ and after the subsequent 5 -day shelf-life period at $20^{\circ} \mathrm{C}$ in season 1 (S1), season 2 (S2) and season 3 (S3). Vertical bars represent LSD intervals ( $p \leq 0.05)$.

Film: fruit packed in plastic film without wax. Wax+Film: fruit waxed and packed in plastic film. $\mathrm{CO}_{2}$ : fruit submitted to $\mathrm{CO}_{2}$ treatment. Wax+Pallet: fruit waxed and boxes stacked on a wooden pallet, which was strapped with macroperforated stretch film. $D A: 1$ day after $\mathrm{CO}_{2}$ treatment. 
The fruit packed in plastic film with no added wax (Film fruit) had similar values to those at harvest throughout cold storage. Although the $\mathrm{AcH}$ concentration slightly increased after the shelf-life periods, the maximum values did not exceed $0.7 \mathrm{mg} / 100 \mathrm{~mL}$.

In the Wax+Film fruit, AcH gradually increased throughout cold storage. So, in the first and second season the AcH content obtained values close to 0.8 $\mathrm{mg} / 100 \mathrm{~mL}$ after 15 days at low temperature, which coincided with a significant drop in ST. From this time point, the AcH concentration continued to rise concomitantly with a drop in ST. After 30 cold storage days, when fruit was evaluated as non-astringent, the AcH content came close to $2.5 \mathrm{mg} / 100$ $\mathrm{mL}$ and $3.5 \mathrm{mg} / 100 \mathrm{~mL}$ for 'Rojo Brillante 'and 'Triumph', respectively. It should be noted that similar $\mathrm{AcH}$ values were found during the second season (Fig. 2b, 2c) in the fruit evaluated as being non-astringent after the shelf-life that followed the 15 and 21 cold storage days. Under industrial conditions (third season), loss of astringency after 30 cold storage days in the Wax+Film fruit was associated with an $\mathrm{AcH}$ concentration of $3.5 \mathrm{mg} / 100 \mathrm{~mL}$. Nevertheless, in the palletized fruit (Wax+Pallet), this value was lower, 2 $\mathrm{mg} / 100 \mathrm{~mL}$ (Fig. 2d).

According to these results, an $\mathrm{AcH}$ concentration in fruit flesh within the 2 and $3.5 \mathrm{mg} / 100 \mathrm{~mL}$ range was necessary to achieve a low enough ST content ( $\leq$ $0.03 \%)$ to not induce perceived astringency. This $\mathrm{AcH}$ range is consistent with previous studies, in which similar $\mathrm{AcH}$ values have been measured in nonastringent fruit after $\mathrm{CO}_{2}$ treatment (Besada et al. 2010; Novillo et al. 2013; 2015; Salvador et al. 2007). In the present study, this $\mathrm{AcH}$ content was achieved only 1 day after $\mathrm{CO}_{2}$ treatment, whereas 30 cold storage days or 15 days plus the shelf-life were required to reach the same $\mathrm{AcH}$ concentration in the waxed fruit.

Regarding the EtOH content values went below $6 \mathrm{mg} / 100 \mathrm{~mL}$ at harvest in both cultivars (Fig. 2e, 2f, $2 \mathrm{~g}, 2 \mathrm{~h}$ ). In the $\mathrm{CO}_{2}$-treated fruit, the EtOH content significantly increased 1 day after treatment (DA). Values of $35 \mathrm{mg} / 100 \mathrm{~mL}$ and $65 \mathrm{mg} / 100 \mathrm{~mL}$ were detected in 'Rojo Brillante' in the first and second season respectively. The EtOH content in 'Triumph' (Fig. $2 \mathrm{~g}$ ) was higher and came close to $78 \mathrm{mg} / 100 \mathrm{~mL}$. These EtOH values remained constant throughout cold 
storage and the subsequent shelf-life periods. The film fruit accumulated very little EtOH during storage. Nevertheless, in the Wax+Film fruit, EtOH accumulation was in flesh after 15 cold storage days, and values did not relevantly change until the end of the study. In 'Rojo Brillante', the EtOH values were $80 \mathrm{mg} / 100 \mathrm{~mL}$ during the first season and came close to $180 \mathrm{mg} / 100 \mathrm{~mL}$ during the second season. In 'Triumph', the EtOH values came close to 200 $\mathrm{mg} / 100 \mathrm{~mL}$. In the third season, differences in $\mathrm{EtOH}$ were found between the Wax+Film and palletized fruit (Wax+Pallet). The Wax+Film fruit showed $150 \mathrm{mg}$ $\mathrm{EtOH} / 100 \mathrm{ml}$ after 30 storage days while the EtOH values of the palletized-fruit were significantly lower (close to $50 \mathrm{mg} / 100 \mathrm{~mL}$ ).

In this study, the applied wax formulation contained ethanol. Therefore, the $\mathrm{AcH}$ required to insolubilize tannins would be produced mainly by alcohol dehydrogenase directly from the EtOH that accumulated in flesh, as reported by other authors after studying the effectiveness of deastringency treatments by EtOH vapor (Taira et al. 1989; Yamada et al. 2002).

According to the EtOH measures taken inside plastic bags, an increment 1 day after cold storage to values of $0.5 \mu \mathrm{L} / \mathrm{L}$ and $0.7 \mu \mathrm{L} / \mathrm{L}$ was observed in the Wax+film 'Triumph' fruit and the 'Rojo Brillante' fruit, respectively. After 15 days however, this concentration dropped to those values found in plastic films with the unwaxed fruit (values close to 0.04) (Table 2). The low EtOH concentration that accumulated in plastic films allowed us to assume that the gradual increase in $\mathrm{AcH}$ in flesh during cold storage would be promoted by EtOH diffused through skin from wax into the parenchymal tissue, instead of from ethanol vapors. Yamasaki et al. (2017) also reported astringency removal 'on tree' using ethanol stickers to release $\mathrm{EtOH}$ to the fruit surface. 
Table 2. EtOH ( $\mu \mathrm{L} / \mathrm{L})$ and $\mathrm{CO}_{2}(\%)$ of persimmons 'Rojo Brillante' and 'Triumph' during storage at $0^{\circ} \mathrm{C}$ in season 1 (S1), season 2 (S2) and season 3 (S3).

*Different letters indicate statistical differences $(p \leq 0.05)$.

Film: fruit packed in plastic film without wax. Wax+Film: fruit waxed and packed in plastic film

Days at $0^{\circ} \mathrm{C}$

\begin{tabular}{|c|c|c|c|c|c|c|c|c|c|}
\hline \multirow[t]{2}{*}{$\begin{array}{c}\text { Season } \\
\text { (Cultivar) }\end{array}$} & \multirow[t]{2}{*}{ Treatment } & \multicolumn{2}{|c|}{$1 d$} & \multicolumn{2}{|c|}{$15 d$} & \multicolumn{2}{|c|}{$21 d$} & \multicolumn{2}{|c|}{$30 d$} \\
\hline & & EtOH & $\mathrm{CO}_{2}$ & $\mathrm{EtOH}$ & $\mathrm{CO}_{2}$ & EtOH & $\mathrm{CO}_{2}$ & $\mathrm{EtOH}$ & $\mathrm{CO}_{2}$ \\
\hline S1 & Film & - & - & 0a* & $0.2 b$ & $\mathrm{Oa}$ & $0.6 b$ & 0 & $0 a$ \\
\hline (Rojo Brillante) & Wax+Film & - & - & $0.02 b$ & $0.4 b$ & $0.02 b$ & $0.7 \mathrm{~b}$ & $0.02 b$ & $0.01 a$ \\
\hline S2 & Film & $0 a$ & $0.63 b$ & $0.01 a$ & $0.32 a$ & $0.01 a$ & $0.69 b$ & $0.01 a$ & $0.36 a$ \\
\hline (Rojo Brillante) & Wax+Film & $0.67 d$ & $0.6 \mathrm{~b}$ & $0.08 c$ & $0.66 \mathrm{~b}$ & $0.04 b$ & $0.57 b$ & $0.02 a$ & $0.53 b$ \\
\hline S2 & Film & $0 \mathrm{a}$ & $0.36 a$ & $0.01 a$ & $0.72 b$ & $0.01 a$ & $0.72 b$ & $0.01 a$ & $0.42 a$ \\
\hline (Triumph) & Wax+Film & $0.47 c$ & $0.49 a$ & $0.04 b$ & $0.84 b$ & $0.04 b$ & $0.84 b$ & $0.02 a$ & $0.51 a$ \\
\hline S3 & Film & - & - & - & - & - & - & $0 a$ & - \\
\hline (Rojo Brillante) & Wax+Film & - & - & - & - & - & - & $0.02 a$ & - \\
\hline
\end{tabular}

It is also noteworthy that like other fruits, EtOH accumulation may play an important role in off-flavors developing in persimmon (Pesis 2005). In line with this, Ben-Arie et al. (1991) studied the effect of modified atmospheres during persimmon storage and reported how $\mathrm{EtOH}$ that accumulated to levels exceeding $75 \mathrm{mg} / 100 \mathrm{~mL}$ was related to deteriorated taste. Nevertheless, in other studies, values of $100 \mathrm{mg} \mathrm{EtOH} / 100 \mathrm{~mL}$ in 'Rojo Brillante' or $200 \mathrm{mg} / 100$ $\mathrm{mL}$ in 'Triumph' had no negative effect on fruit taste (Besada et al. 2014). The maximum EtOH values herein detected came close to $200 \mathrm{mg} / 100 \mathrm{~mL}$ and were, in any case, associated by the panelists with a negative change in fruit flavor (data not shown). 


\subsection{External color and flesh firmness}

The two studied cultivars were harvested in all three seasons with homogeneous coloration and color index values between +8 and +11 , but no relevant changes in external coloration were detected during the cold storage period (data not shown). Nevertheless, when fruit were transferred to shelflife conditions, a significant increase took place. Thus the 'Rojo Brillante' values came close to +20 , and to +15 for 'Triumph', after the shelf-life following 30 days storage at $0{ }^{\circ} \mathrm{C}$. In any case, differences among treatments were found.

One of the most important parameters for preservation during the cold storage of persimmon is flesh firmness. It is stressed that most persimmon cultivars have been widely reported to exhibit chilling injury symptoms when stored at low temperatures, and firmness loss is the main chilling injury symptom. Such flesh softening can be exhibited during cold storage at $4-11^{\circ} \mathrm{C}$ (Arnal \& Río 2004). However, during storage at 0-1 ${ }^{\circ} \mathrm{C}$, drastic firmness loss occurs mainly when fruit are transferred to shelf-life temperatures (Salvador et al. 2004; 2006). Thus the application of 1-MCP prior to storage has become a common treatment before submitting fruit to low temperatures as it reduces chilling injury symptoms in many persimmon cultivars (Kim \& Lee 2005; Salvador et al. 2004; Tessmer et al. 2019). In the present study, all the fruit were submitted to commercial 1-MCP treatment after harvest to preserve flesh firmness.

In the first and second seasons, fruit were harvested with high flesh firmness values of around $40-45 \mathrm{~N}$. In the third season, the initial firmness was slightly lower (close to $35 \mathrm{~N}$ ). During cold storage, firmness slightly decreased in all cases. After transferring fruit from cold storage to shelf-life conditions, firmness loss became more evident, but flesh firmness remained crispy with values above $25 \mathrm{~N}$ during the first and second seasons. It was only during the third season when fruit underwent more marked firmness loss, with values close to $15 \mathrm{~N}$. In any case, differences among the assayed treatments were found. 


\subsection{Internal and external disorders}

Throughout the study period, no external disorders were observed. Nevertheless, flesh browning was exhibited only in 'Rojo Brillante' subjected to $\mathrm{CO}_{2}$ treatment after the shelf-life that following the 30 cold storage days (Fig. 3). The Browning Index gave values of 0.2 and 0.3 in the first and the second season, respectively (data not shown). The wax-treated fruit (Wax+Film) did not show any browning (Fig. 3).

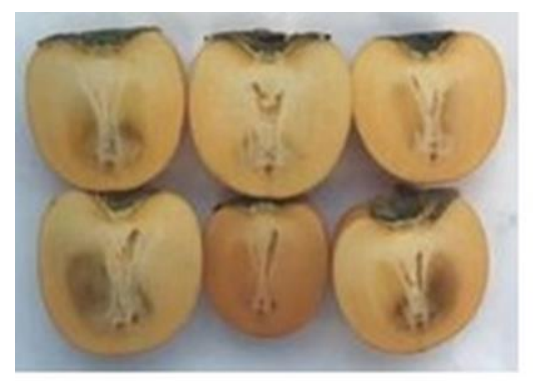

$\mathrm{CO}_{2}$

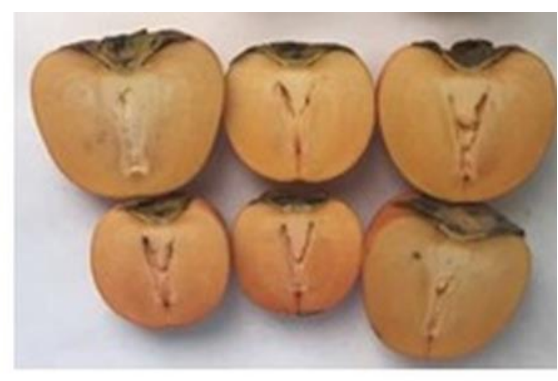

Wax+Film

Fig. 3. Internal quality of the 'Rojo Brillante' fruit treated with either $\mathrm{CO}_{2}$ or the new wax after 30 days of cold storage, plus the 5 -day shelf-life at $20^{\circ} \mathrm{C}$

Different postharvest factors have been associated with internal persimmon browning, such as storage in controlled atmospheres and mechanical damage (Besada et al. 2014; Novillo et al. 2014), and browning symptoms differ depending on the causal factor.

The herein manifested flesh browning was visualized in the central fruit area, similarly to that reported to be induced by storage in controlled atmospheres (Besada \& Salvador 2018). It is noteworthy that this alteration is not new to us because it has often been visualized in those persimmons submitted to $\mathrm{CO}_{2}$ treatment before being cold-stored for lengthy periods. Indeed, the causes of this disorder are currently being studied by our group. 
In other fruits, tissue browning and cell death have been linked to the $\mathrm{AcH}$ that accumulates under anaerobic conditions (Fan et al. 2005; Zhang et al. 2015). Accordingly, the browning manifestation herein found in the fruit subjected to $\mathrm{CO}_{2}$ treatment could be related to $\mathrm{AcH}$ accumulating in flesh. So the $\mathrm{CO}_{2}$ fruit achieved the maximum AcH level only 1 day after treatment and this high $\mathrm{AcH}$ concentration in flesh remained constant throughout the study period. Nevertheless, in the wax-treated fruit, $\mathrm{AcH}$ accumulation was gradual and it was only after 30 days when it reached similar levels to those of the $\mathrm{CO}_{2}$ treated fruit. Thus the period that flesh is exposed to high AcH levels seems crucial for browning development.

\section{Conclusion}

The patented process based on new wax is revealed as an effective deastringency treatment during the cold storage of persimmons 'Rojo Brillante' and 'Triumph'. Complete astringency removal is achieved in both varieties with no fruit quality loss after 30 storage days at $0{ }^{\circ} \mathrm{C}$ and after the shelf-life period that followed 15 and 21 storage days. Therefore, this method is an alternative to $\mathrm{CO}_{2}$ treatment when prolonged cold storage is required, as on shipments to far overseas markets.

This study corroborates that applying $\mathrm{CO}_{2}$ deastringency treatment to persimmon implies an important quality loss risk associated with flesh browning manifestation after prolonged cold storage.

\section{Acknowledgements}

This work has been funded by the Instituto Nacional de Investigación y Tecnología Agraria y Alimentaria (INIA) and Fondo Europeo de Desarrollo Regional (FEDER) through Project RTA2017-00045-C02-01. Ayoub Fathi Najafabadi thanks the INIA for grant FPI-INIA \#43 (CPD2015-0151). The authors thank Fomesa Fruitech S.L.U. and Natural Hand S. L. for their technical support. 


\section{References}

Arnal, L., \& Del Río, M.A. (2004). Quality of persimmon fruit cv. Rojo brillante during storage at different temperatures. Spanish Journal of Agricultural Research. 2, 243-247. https://doi.org/10.5424/sjar/2004022-78

Arnal, L., \& Del Río, M.A. (2003). Removing astringency by carbon dioxide and nitrogen-enriched atmospheres in persimmon fruit cv. "Rojo brillante". Journal of Food Science. 68(4),1516-1518. https://doi.org/10.1111/j.13652621.2003.tb09676.x

Ben-Arie, R., Zutkhi, Y., Sonego, L., \& Klein, J. (1991). Modified atmosphere packaging for long-term storage of astringent persimmons. Postharvest Biology and Technology. 1(2), 169-179. htts://doi.org/10.1016/09255214(91)90009-Zp

Blum, j., Broday Hoffmann, F., Ayub, R.A., Delourdes Jung, D., \& Barboza Malgarim, M. (2008). Uso de cera na conservação pós-colheita do caqui cv. Giombo. Revista brasileira de fruticulture. 30(3), 830-833. https://doi.org/10.1590/S0100-29452008000300046

Besada, C., \& Salvador, A. (2018) Postharvest Biology and Technology of Persimmon. In: Mir S, Shah M, Mir M (eds). Postharvest Biology and Technology of Temperate Fruits. Springer, Cham, pp 371-393. https://doi.org/10.1007/978-3-319-76843-4_16

Besada, C., Munera, S., Gil, R., Cubero, S., Aleixos, N., \& Salvador, A. (2016). El análisis de imagen como herramienta para evaluar de forma objetiva la reacción de los taninos solubles del caqui con el cloruro férrico. Levante Agrícola, Especial Postcosecha. ํㅜ 432, 181-185.

Besada, C., Novillo, P., Navarro, P., \& Salvador, A. (2014). Effect of a low oxygen atmosphere combined with 1-MCP pretreatment on preserving the quality of "Rojo Brillante" and "Triumph" persimmon during cold storage. Scientia Horticulturae. 179, 51-58. https://doi.org/10.1016/j.scienta.2014.09.015 
Besada, C., Salvador, A., Arnal, L., \& Martínez-Jávega, J.M. (2010). Optimization of the duration of deastringency treatment depending on persimmon maturity. Acta Horticulturae. 858, 69-74. https://doi.org/10.17660/ActaHortic.2010.858.7

Carvalho da Silva, M., Eiko Atarassi, M., Ferreira, M.D., \& Mosca, M.A. (2011). Qualidade pós-colheita de caqui 'fuyu' com utilização de diferentes concentrações de cobertura comestível. Ciência e Agrotecnologia. 35(1), 144-151. https://doi.org/10.1590/S1413-70542011000100018

Fan, L., Song, J., Forney, C.F., \& Jordan, M.A. (2005). Ethanol production and chlorophyll fluorescence in heat-stressed apple fruit during storage. Acta Horticulturae. 682(2),

901-908. https://doi.org/10.17660/ActaHortic.2005.682.117

Khademi, O., Salvador, A., Zamani, Z., \& Besada, C. (2013). Effects of hot water treatments on antioxidant enzymatic system in reducing flesh browning of persimmon. Food and Bioprocess Technology. 6(11), 3038-3046. https://doi.org/10.1007/s11947-012-0959-6

Kim, Y.K., \& Lee, J.M. (2005). Extension of storage and shelf-life of sweet persimmon with 1-MCP. Acta Horticulturae. 685:165-174. https://doi.org/10.17660/ActaHortic.2005.685.19

Munera, S., Besada, C., Aleixos, R., Talens, P., Salvador, A., Sun, D-W., Cubero, S., \& Blasco, J. (2017). Non-destructive assessment of the internal quality of intact Persimmon using color and VIS/NIR hyperspectral imaging. LWTFood Science and Technology. 241-248. https://doi.org/10.1016/j.Iwt.2016.11.063

Nair, M.S., Saxena, A., \& Kaur, C. (2018). Characterization and antifungal activity of pomegranate peel extract and its use in polysaccharide-based edible coatings to extend the shelf-life of capsicum (Capsicum annuum L.). Food and Bioprocess Technology. 11(7), 1317-1327. https://doi.org/10.1007/s11947-018-2101-x 
Novillo, P., Gil, R., Besada, C., \& Salvador, A. (2015). Astringency removal of "Rojo Brillante" persimmon by combining $\mathrm{CO} 2$ and ethanol application. Acta Horticulturae.

1079,

599-604. https://doi.org/10.17660/ActaHortic.2015.1079.81

Novillo, P., Salvador, A., Llorca, E., Hernando, I., \& Besada, C. (2014). Effect of $\mathrm{CO} 2$ deastringency treatment on flesh disorders induced by mechanical damage in persimmon. Biochemical and microstructural studies. Food Chemistry. 145 , 454-463. https://doi.org/10.1016/j.foodchem.2013.08.054

Novillo, P., Besada, C., Gil, R., \& Salvador, A. (2013). Fruit quality and response to deastringency treatment of eight persimmon varieties cultivated under spanish growing conditions. Acta Horticulturae. 996, 437-442. https://doi.org/10.17660/ActaHortic.2013.996.63

Pesis, E. (2005). The role of the anaerobic metabolites, acetaldehyde and ethanol, in fruit ripening, enhancement of fruit quality and fruit deterioration. Postharvest Biology and Technology. 37(1), 1-19. https://doi.org/10.1016/j.postharvbio.2005.03.001

Pesis, E., Levi, A., \& Ben-Arie, R. (1988). Role of acetaldehyde production in the removal of astringency from persimmon fruits under various modified atmospheres. Journal of Food Science. 53(1), 153-156. https://doi.org/10.1111/j.1365-2621.1988.tb10197.x

Rojas-Graü, M.A., Raybaudi-Massilia, R.M., Soliva-Fortuny, R.C., AvenaBustillos, R.J, McHugh, T.H., \& Martín-Belloso, O. (2007). Apple pureealginate edible coating as carrier of antimicrobial agents to prolong shelflife of fresh-cut apples. Postharvest Biology and Technology. 45(2), 254264. https://doi.org/10.1016/j.postharvbio.2007.01.017

Salvador, A., Arnal, L., Besada, C., Larrea, V., Quiles, A., \& Pérez-Munuera, I. (2007). Physiological and structural changes during ripening and deastringency treatment of persimmon fruit cv. "Rojo Brillante". 
Postharvest Biology and Technology. 46(2), 181-188. https://doi.org/10.1016/j.postharvbio.2007.05.003

Salvador, A., Arnal, L., Carot, J.M., Carvalho, C.P., \& Jabaloyes, J.M. (2006). Influence of different factors on firmness and color evolution during the storage of persimmon cv. "Rojo Brillante". Journal of Food Science. 71(2), 169-175. https://doi.org/10.1111/j.1365-2621.2006.tb08921.x

Salvador, A., Arnal, L., Monterde, A., \& Cuquerella, J. (2004). Reduction of chilling injury symptoms in persimmon fruit cv. "Rojo Brillante" by 1-MCP. Postharvest Biology and Technology. 33(3), 285-291. https://doi.org/10.1016/j.postharvbio.2004.03.005

Taira, S., Itamura, H., Abe, K., \& Watanabe, S. (1989). Comparison of the characteristics of removal of astringency in two japanese persimmon cultivars, 'Denkuro and Hiratanenashi'. Journal of the Japanese Society for Horticultural Science, 58(2), 319-325

Tessmer, M.A., Appezzato-da-Glória, B., \& Kluge, R.A. (2019). Evaluation of storage temperatures to astringency 'Giombo' persimmon: Storage at 1 ${ }^{\circ} \mathrm{C}$ combined with 1-MCP is recommended to alleviate chilling injury. Scientia Horticulturae. 108675. https://doi.org/10.1016/j.scienta.2019.108675

Tessmer, M.A., Da Glória, B.A., \& Kluge, R.A. (2018). Astringency reduction using ethanol-associated to the storing under refrigeration at $5^{\circ} \mathrm{C}$ promotes physiological and structural alterations in "Giombo" persimmons. Comunicata Scientiae. 9(3), 449-456. https://doi.org/10.14295/CS.v9i3.2014

Vidrih, R., Simcic, M., Hribar, J., \& Plestenjak, A. (1994). Astringency removal by high $\mathrm{CO} 2$ treatment in persimmon fruit (Diospyros Kaki). Acta Horticulturae. 368 , 652-656. https://doi.org/10.17660/actahortic.1994.368.77 
Yamada, M., Taira, S., Ohtsuki, M., Sato, A., Iwanami, H., Yakushiji, H., \& Li, G. (2002). Varietal differences in the ease of astringency removal by carbon dioxide gas and ethanol vapor treatments among Oriental astringent persimmons of Japanese and Chinese origin. Scientia Horticulturae. 94(12), 63-72. https://doi.org/10.1016/S0304-4238(01)00367-3

Yamasaki, A., Yakushiji, H., Iwamoto, H., Azuma, A., \& Sugiura, H. (2017). Optimum conditions for on-tree ethanol-sticker treatment for astringency removal in 'Taigetsu' and 'Taiten' persimmons. Horticulture Journal. 86(4), 463-469. https://doi.org/10.2503/hortj.okd-039

Zhang, S., Shi, Y., Deng, B. (2015). Exogenous carbon monoxide treatment delayed the ethanol metabolism and fruit softening of postharvest Jujube. Asian Journal of Agricultural and Food Sciences. 03(02):196-204. 
III.2. PRE- AND POSTHARVEST METHODS TO GUARANTEE FRUIT QUALITY AFTER COLD STORAGE IN PACKING HOUSES

CHAPTERS III, IV and V 



\title{
Efecto de múltiples aplicaciones de Ácido Giberélico sobre la maduración y calidad postcosecha del caqui 'Rojo Brillante'
}

\section{Ayoub Fathi Najafabadi, Cristina Besada, Rebeca Gil, Pilar Navarro, Alejandra Salvador}

\author{
Departamento de Tecnología Postcosecha, Instituto Valenciano de \\ Investigaciones Agrarias, 46113 Valencia, Spain.
}

Reference: Under Review: Levante Agrícola 



\section{Resumen}

La aplicación de ácido giberélico $\left(\mathrm{AG}_{3}\right)$ en campo es una práctica habitual para retrasar la maduración del caqui 'Rojo Brillante' y poder así escalonar la recolección. En la actualidad se están llevando a cabo hasta tres aplicaciones de este tratamiento, sin embargo no hay información contrastada que justifique la necesidad de realizar múltiples aplicaciones. En este estudio se ha evaluado el efecto sobre la maduración del fruto de una, dos y tres aplicaciones de $\mathrm{AG}_{3}$ en precosecha. Además, se ha evaluado el efecto de la combinación de las distintas aplicaciones de $\mathrm{AG}_{3}$ en precosecha con el tratamiento postcosecha de Smartfresh ${ }^{\circledast}$ sobre la calidad del fruto. Para ello se realizaron tres recolecciones entre mediados de noviembre y principios de diciembre, y se ensayó una conservación a $0{ }^{\circ} \mathrm{C}$ de 30 y 60 días, simulando también las condiciones posteriores de comercialización ( 5 días a $20{ }^{\circ} \mathrm{C}$ ). Los resultados obtenidos mostraron que el efecto de retraso de la maduración asociado a una aplicación de $\mathrm{AG}_{3}$ se vio potenciado por una segunda aplicación realizada al cabo de dos semanas. Sin embargo, una tercera aplicación no supuso un mayor retraso de la maduración. En la recolección realizada a mediados de noviembre la combinación de $\mathrm{AG}_{3}$ y Smartfresh ${ }^{\oplus}$ podría alargar la conservación hasta los 60 días, sin observarse diferencias en función del número de aplicaciones de $\mathrm{AG}_{3}$. En las recolecciones de final de noviembre y principio de diciembre el tratamiento de $\mathrm{AG}_{3}$ permitió una conservación de hasta 30 días, presentando mayores firmezas la fruta con 2-3 pases en comparación con un único pase.

Keywords: ácido giberélico, smartfresh ${ }^{\circledR}$, conservación, color, firmeza, daño por frío 


\section{Introducción}

La producción de caqui en la Comunidad Valenciana se basa principalmente en la variedad 'Rojo Brillante', que es una variedad astringente en recolección. La introducción de tratamientos con altas concentraciones de $\mathrm{CO}_{2}$, que permiten eliminar la astringencia del fruto con elevada firmeza, fue uno de los principales motores para el rápido crecimiento de este cultivo en las dos últimas décadas.

Bajo condiciones agronómicas y climáticas mediterráneas la maduración comercial del caqui 'Rojo Brillante' comprende desde mediados de octubre a diciembre. El drástico incremento en el volumen de producción en los últimos años ha llevado a una gran concentración de la oferta en un período de tiempo relativamente corto, con los consiguientes problemas comerciales. En la actualidad, uno de los principales objetivos del sector productor y comercializador de caqui es conseguir ampliar la campaña comercial del caqui 'Rojo Brillante', y para ello se están abordando dos estrategias principales. Por una parte, la ampliación del período de recolección mediante la aplicación de tratamientos precosecha que adelanten o retrasen la maduración y, por otra parte, la aplicación de tecnología de conservación que permita alargar su vida postcosecha. Uno de los principales tratamientos aplicados en precosecha es el ácido giberélico $\left(\mathrm{AG}_{3}\right)$. La aplicación de $\mathrm{AG}_{3}$ cuando la fruta alcanza el viraje de color provoca un retraso en la madurez de la fruta, pospone el cambio de color de verde a naranja, mejora el aspecto de los lóbulos del sépalo y tiene un efecto sobre la composición de la pared celular retrasando el ablandamiento de la pulpa (Ben-Arie et al., 1996, 1997; Agustí et al., 2003, 2004). Así la aplicación de $\mathrm{AG}_{3}$ a dosis $30 \mu \mathrm{L} \mathrm{L} \mathrm{L}^{-1}$ en el momento de viraje de color se ha convertido en una práctica habitual para el retraso de la maduración del caqui ‘Rojo Brillante' alrededor de 15 días, permitiendo así escalonar la recolección.

Por otra parte, una de las principales causas de pérdidas postcosecha del caqui 'Rojo Brillante' es la incidencia de alteraciones durante el almacenamiento frigorífico, asociadas principalmente a la sensibilidad de esta variedad a manifestar daños por frío (disminución drástica de la firmeza que puede ir acompañada de gelificación y oscurecimiento interno de la pulpa). Estas alteraciones se manifiestan principalmente cuando el fruto es transferido a 
temperaturas moderadas de transporte y comercialización, después de almacenamientos prolongados a bajas temperaturas (Besada et al., 2014; Novillo et al., 2015). La aplicación de 1-metilciclopropeno (Smartfresh ${ }^{\circledR}$ ), un potente inhibidor de la acción del etileno, previa a la conservación frigorífica se ha mostrado como una herramienta muy potente para retrasar los síntomas de daño por frío en diferentes variedades de caqui (Girardi et al., 2003; Brackam et al., 2004; Kim \& Lee 2005, Tibola et al., 2005). Desde hace ya más de una década, la aplicación de Smartfresh ${ }^{\circledR}$ es una práctica habitual durante la conservación del caqui 'Rojo Brillante'.

En el año 2008, Besada et al. demostraron que el uso combinado de $A_{3}$ en precosecha y Smartfresh ${ }^{\circledR}$ en postcosecha permitía prolongar la conservación del caqui 'Rojo Brillante' respecto a la aplicación de únicamente Smartfresh ${ }^{\circledR}$ (Besada et al., 2008). En este trabajo se evaluó el efecto de una única aplicación de $A G_{3}$, ya que era la práctica habitual en ese momento. Sin embargo en la actualidad es habitual realizar hasta tres aplicaciones periódicas de $A G_{3}$ con el objetivo de potenciar el efecto de retraso de la maduración, pero no existen estudios sobre las ventajas de una aplicación múltiple de este tratamiento.

En este contexto, el objetivo de este trabajo fue evaluar el efecto de hasta 3 aplicaciones periódicas de $\mathrm{AG}_{3}$ sobre la madurez del caqui 'Rojo Brillante' y su posterior conservación frigorífica en combinación con Smartfresh ${ }^{\circledR}$.

\section{Materiales y métodos}

Los ensayos se realizaron en árboles adultos en una parcela comercial de caqui cv. Rojo Brillante, situada en Albal (Valencia), en la que se realizaron hasta un máximo de 3 aplicaciones de $\mathrm{AG}_{3}$ a dosis de $30 \mu \mathrm{L} \mathrm{L}^{-1}$. Cada uno de los tres tratamientos ensayados $\left(1,2 \circ 3\right.$ pases de $A G_{3}$ ) fue evaluado sobre 6 árboles situados en una misma fila, dejando filas guarda entre los distintos tratamientos. La primera aplicación de $\mathrm{AG}_{3}$ se realizó en el momento de viraje de color (10 de octubre) y las demás con una cadencia de 15 días. Como control se utilizaron árboles que no habían sido tratados (CTL). 
En los tres momentos de aplicación de $\mathrm{AG}_{3}$ se realizó la medición del color de los frutos en árbol. Posteriormente, entre mediados de noviembre y principios de diciembre, de cada uno de los tratamientos ensayados se realizaron tres recolecciones (13 de noviembre, 27 de noviembre y 5 de diciembre). En cada una de las recolecciones se cosecharon 180 frutos por tratamiento, que se trasladaron al Instituto Valenciano de Investigaciones Agrarias (IVIA) donde, tras una selección previa para evitar la presencia de frutos dañados, se confeccionaron 5 lotes uniformes de 30 frutos por tratamiento con coloración homogénea. Uno de los lotes fue directamente analizado para evaluar el estado de los frutos en el momento de cosecha, y los otros cuatro fueron tratados con Smartfresh ${ }^{\circledast}\left(500 \mathrm{~nL} \mathrm{~L}^{-1}, 24 \mathrm{~h}, \mathrm{~T}^{\mathrm{a}}\right.$ ambiente), previamente a su almacenamiento frigorífico a $0{ }^{\circ} \mathrm{C}$ durante 30 y 60 días.

Transcurridos de 30 y 60 días se extrajeron de la cámara frigorífica dos lotes por tratamiento. Uno de los lotes fue evaluado directamente tras la salida de la cámara a $0{ }^{\circ} \mathrm{C}$ y el otro lote se sometió al tratamiento de desastringencia con altas concentraciones de $\mathrm{CO}_{2}$ en condiciones estándar $\left(95 \% \mathrm{CO}_{2}, 20^{\circ} \mathrm{C}, 24 \mathrm{~h}\right)$ y posteriormente se transfirió a una cámara a $20{ }^{\circ} \mathrm{C}$ durante 5 días simulando un periodo de comercialización, tras el cual se llevó a cabo su evaluación.

Tanto en el momento de recolección como tras los diferentes periodos de conservación en frío y posterior comercialización se evaluó el color externo y la firmeza del fruto. El color de la piel se medió en dos caras opuestas de la zona ecuatorial con un Colorimetro Minolta (Model CR-300, Ramsey, NY, USA) y fue expresado como IC = 1000a/Lb ('L', ' $a$ ', ' 'b' parámetros de Hunter). La firmeza se determinó con un Texturómetro Instron Universal Machine Modelo 4301(Instron Corp., Canton, MA, USA), usando una sonda de base plana de 8 $\mathrm{mm}$. Las medidas fueron realizadas en dos caras opuestas de cada fruto tras retirar la piel en la zona ecuatorial y los valores fueron expresados como la fuerza en Newton (N) necesaria para romper la pulpa. Además, tras los periodos de conservación y comercialización, se evaluó la presencia de alteraciones fisiológicas.

El análisis estadístico se llevó a cabo mediante el análisis de la varianza (ANOVA) con el paquete estadístico Statgraphics Centurion XVII.I (Manugistics 
Inc., Rockville, MD, USA). Las diferencias entre los valores se determinaron a través de intervalos LSD con un nivel de confianza 95\%.

\section{Resultados}

\subsection{Efecto del $A G_{3}$ sobre la maduración del fruto}

En la Figura 1 se muestra la evolución del color externo de los frutos en función del número de aplicaciones de $A_{G}$ recibidas. Se han señalado en la gráfica tanto las fechas de aplicación del tratamiento como las fechas de cada una de las recolecciones realizadas.

La primera aplicación de $\mathrm{AG}_{3}$ se efectuó en el momento de viraje de color, cuando los frutos presentaron un IC de -2. Toda la fruta experimentó un avance de la coloración durante el periodo de campaña desde tonos verdeamarillentos hasta una coloración naranja intensa y homogénea. A lo largo de todo el periodo de estudio, la fruta del tratamiento CTL presentó mayor índice de color que la fruta que fue tratada con $A G_{3}$. Este efecto fue evidente transcurridos 15 días desde la primera aplicación, y se hizo más patente con el avance de la campaña. Así, en la tercera recolección, la diferencia de color entre los frutos $C T L(I C=+25)$ y los frutos tratados con $A G_{3}$ fue de como mínimo 5 puntos, presentando la fruta tratada un IC de +20 o menor.

El número de aplicaciones de $\mathrm{AG}_{3}$ influyó de forma significativa en la evolución del color del fruto. La realización de dos aplicaciones de $A_{3}$ tuvo un mayor efecto en el retraso de la maduración que una única aplicación. Sin embargo, no se observaron diferencias significativas entre la fruta que recibió dos o tres aplicaciones. 


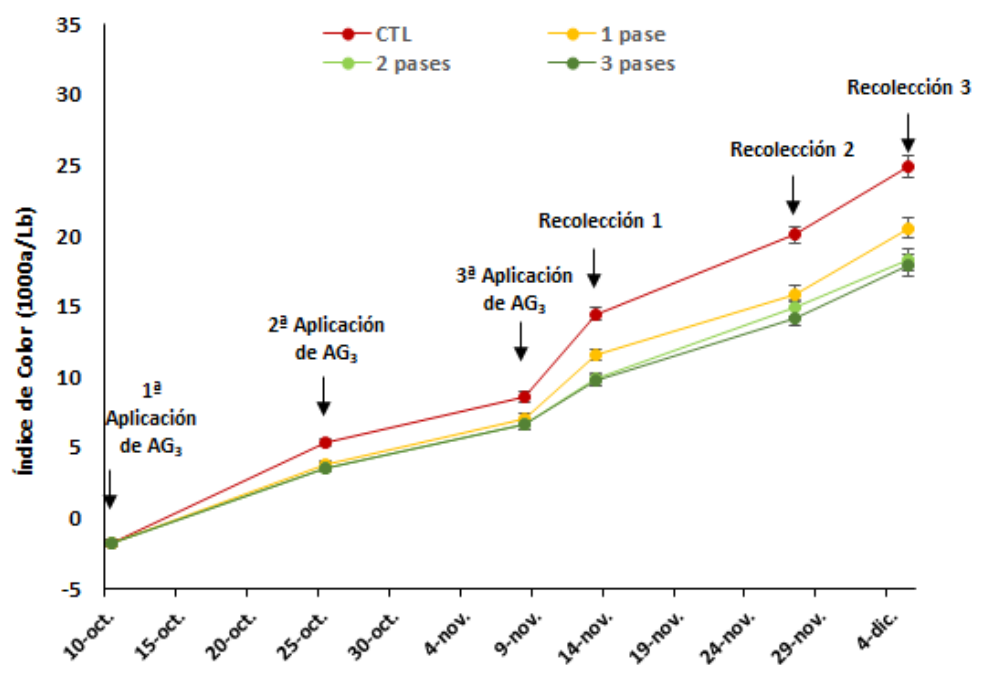

Fig. 1. Evolución del color, momentos de aplicación de $A_{3}$ y fechas de recolección.

3.2. Efecto del $\mathrm{AG}_{3}$ en la calidad del fruto durante la conservación frigorífica

En las Figuras 2, 3 y 4, se muestra para cada una de las recolecciones realizadas, la evolución del color y firmeza durante la conservación frigorífica de 30 y 60 días y la posterior simulación de comercialización, en función del número de aplicaciones de $\mathrm{AG}_{3}$ recibidos en precosecha. El aspecto interno de la fruta se muestra en la Figura 5.

\section{Recolección 1}

En el momento de cosecha (13 de noviembre), la fruta CTL mostraba una coloración más avanzada $(I C=+15)$ y una menor firmeza $(43 \mathrm{~N})$ que la fruta tratada con $\mathrm{AG}_{3}(\mathrm{IC} \approx+10$, firmezas $\approx 50 \mathrm{~N}$ ) (Fig. 2). De entre la fruta tratada, la que sólo había recibido una aplicación mostraba una coloración ligeramente superior a la que había recibido 2 y 3 aplicaciones, mientras que los valores de firmeza fueron similares. 

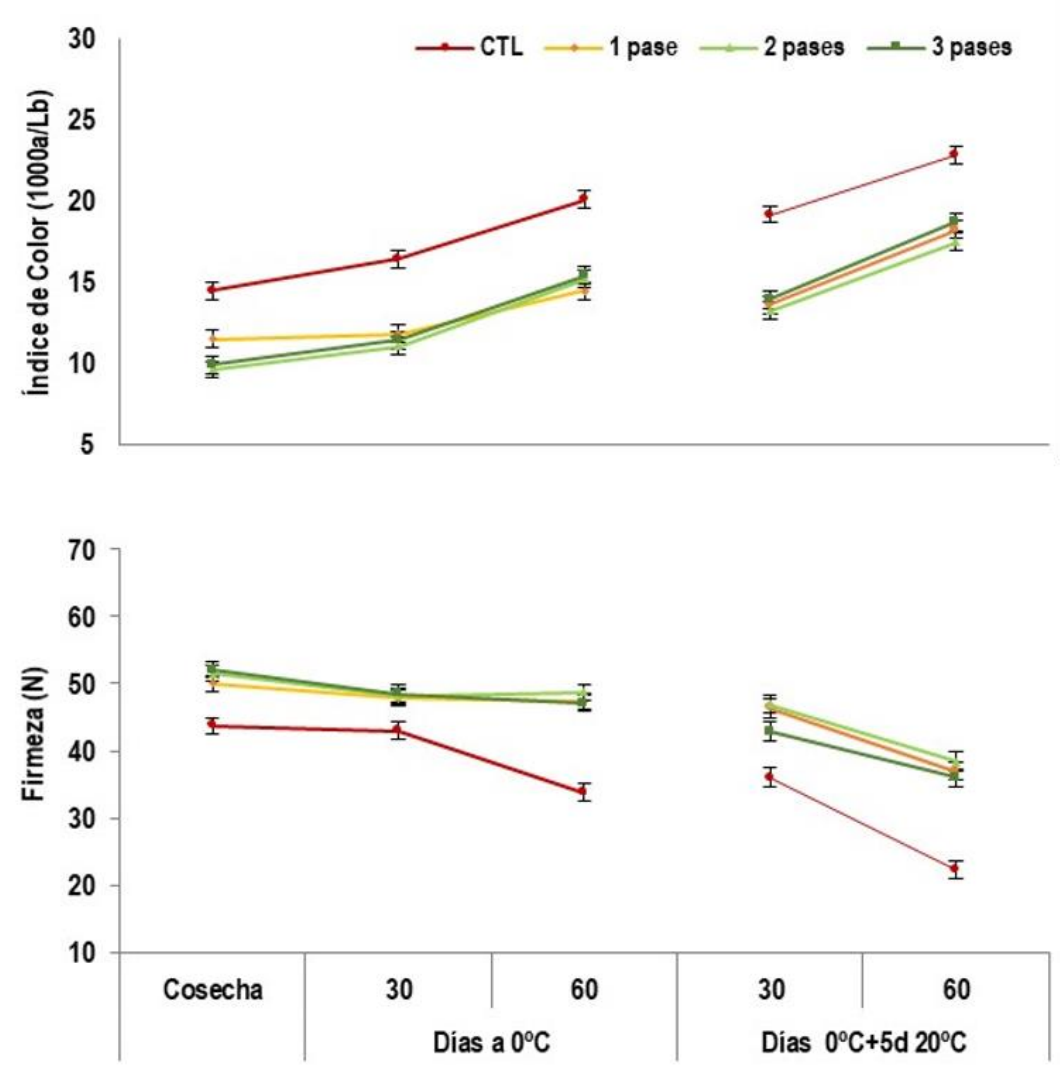

Fig. 2. Color (1000a/Lb) y firmeza (N) de frutos de caqui cv. Rojo Brillante tratados con $\mathrm{AG}_{3}$ (1, 2 ó 3 pases de tratamiento) y no tratados (CTL), en el momento de cosecha, tras una conservación de 30 y 60 días a $0{ }^{\circ} \mathrm{C}$ y una posterior comercialización de 5 días a $20^{\circ} \mathrm{C}$. Fecha de cosecha: 13 de noviembre ( $1^{\mathrm{a}}$ recolección). Las barras verticales representan los intervalos $L S D(P \leq 0,05)$.

Durante el periodo de conservación a $0{ }^{\circ} \mathrm{C}$ toda la fruta experimentó un incremento de color y un descenso de la firmeza. Durante los 30 primeros días de conservación en frío el aumento de color fue muy ligero y los valores de firmeza se mantuvieron relativamente constante en todos los tratamientos. Transcurridos 60 días, toda la fruta experimentó un avance en la coloración, sin embargo, mientras que la fruta CTL sufrió una pérdida importante de firmeza, 
la fruta tratada con $\mathrm{AG}_{3}$ mantuvo valores de firmeza cercanos a los de recolección.

Tras los periodos de comercialización ( 5 días a $20^{\circ} \mathrm{C}$ ) que siguieron a la conservación frigorífica, todos los tratamientos experimentaron un incremento de color, que fue más acusado tras 60 días de conservación. Este cambio de color observado tras transferir la fruta de bajas temperaturas a temperaturas moderadas $\left(20^{\circ} \mathrm{C}\right)$ se vio acompañado de una pérdida de firmeza del fruto. La fruta CTL, fue la que sufrió un mayor ablandamiento. Así, tras la comercialización que siguió a los 60 días de frigoconservación la fruta CTL presentó valores en el límite comercial $(22 \mathrm{~N})$, mientras que la fruta tratada con $\mathrm{AG}_{3}$ presentó valores de firmeza cercanos a los $40 \mathrm{~N}$ independientemente de los pases aplicados.

En la Figura 5 puede observarse como el drástico ablandamiento sufrido por la fruta CTL fue acompañado de la aparición de alteraciones, principalmente síntomas de gelificación y ablandamiento en la parte inferior del fruto acompañada de un oscurecimiento de la pulpa. Este tipo de alteraciones son síntomas de daño por frío típicos de esta variedad y se manifiestan habitualmente cuando la fruta es transferida a temperaturas moderadas (Arnal \& Del Rio 2004). En la fruta tratada con $\mathrm{AG}_{3}$ únicamente se observaron daños por frío, y de intensidad muy ligera, en algún fruto aislado.

\section{Recolección 2}

La segunda recolección se realizó el 27 de noviembre, transcurridas dos semanas desde la primera. Al igual que en la primera recolección, la fruta CTL presentó en el momento de cosecha una mayor coloración y una menor firmeza ( $I C=+20,33 \mathrm{~N}$ de firmeza) que la fruta tratada con $\mathrm{AG}_{3}$ (Fig. 3). En este momento la fruta que había recibido una única aplicación de $A_{3}$ presentó menor firmeza y una coloración ligeramente más avanzada que la que había recibido 2 o 3 aplicaciones, sin diferencias entre estas últimas. 

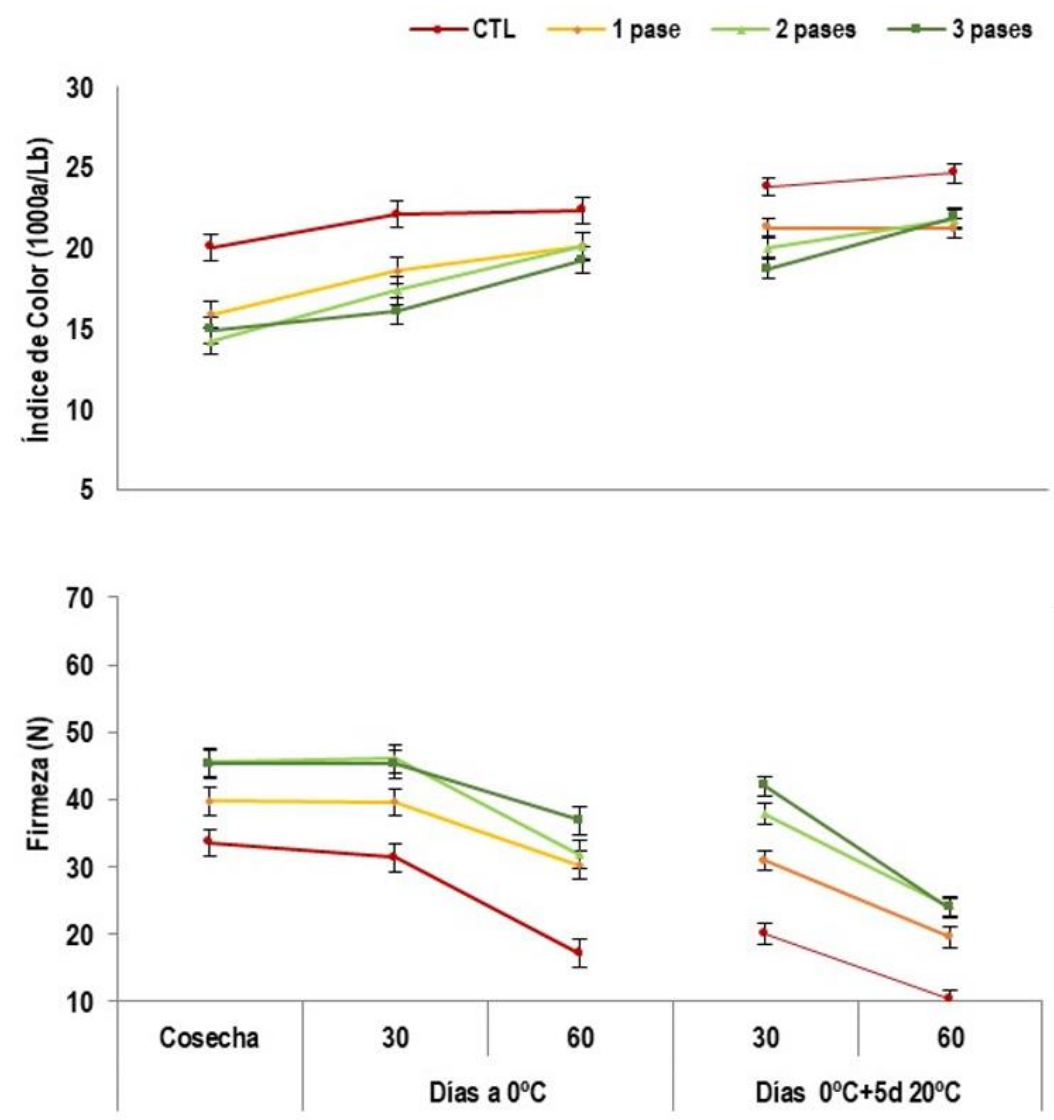

Fig. 3. Color (1000a/Lb) y firmeza (N) de frutos de caqui cv. Rojo Brillante tratados con $\mathrm{AG}_{3}$ (1, 2 ó 3 pases de tratamiento) y no tratados (CTL), en el momento de cosecha, tras una conservación de 30 y 60 días a $0{ }^{\circ} \mathrm{C}$ y una posterior comercialización de 5 días a $20^{\circ} \mathrm{C}$. Fecha de cosecha: 27 de noviembre ( $2^{\mathrm{a}}$ recolección). Las barras verticales representan los intervalos LSD $(P \leq 0,05)$.

Durante la conservación frigorífica toda la fruta experimentó un ligero incremento de la coloración. La firmeza se mantuvo constante durante los 30 primeros días y únicamente tras 60 días se observó un ablandamiento que fue más acusado en la fruta CTL, cayendo a valores inferiores a $20 \mathrm{~N}$.

La transferencia de la fruta a temperaturas de comercialización resultó en un ligero incremento de la coloración similar en todos los tratamientos, pero se 
observaron cambios importantes en cuanto a la firmeza. Así, durante la comercialización que siguió a los 30 días de conservación, la fruta CTL experimentó un ablandamiento equivalente a un descenso de $10 \mathrm{~N}$ en la firmeza. En la fruta que había recibido el tratamiento de $\mathrm{AG}_{3}$, el ablandamiento fue menor (un descenso de $5 \mathrm{~N}$ respecto a los valores en la cámara de frío), manteniendo firmezas elevadas de entre $35 \mathrm{~N}$ (un pase de $A G_{3}$ ) y $40 \mathrm{~N}$ ( 2 y 3 pases de $\mathrm{AG}_{3}$ ).

Cuando la fruta fue transferida a $20^{\circ} \mathrm{C}$ después de una conservación de 60 días a $0{ }^{\circ} \mathrm{C}$, en todos los casos se observó un ablandamiento importante. Esto resultó en valores no comerciales de la fruta CTL (10 N), en la que se manifestaron síntomas claros de daño por frío (Fig. 5). En este momento la fruta tratada con $\mathrm{AG}_{3}$ presentó mayor firmeza, $20 \mathrm{~N}$ la fruta que había recibido un pase, y en torno a $24 \mathrm{~N}$ la que había recibido 2 y 3 aplicaciones. Sin embargo, los síntomas de daño, aunque menos intensos que en la fruta CTL, estuvieron también presentes en la fruta tratada con $A_{3}$, hasta el punto de limitar su comercialización (Fig. 5).

\section{$\underline{\text { Recolección } 3}$}

La tercera recolección fue realizada el 5 de diciembre. En el momento de cosecha, la fruta que había recibido 2 ó 3 pases de $\mathrm{AG}_{3}$ presentaba los mayores valores de firmeza cerca de $40 \mathrm{~N}$ y el menor IC inferior a +20 , mientras que la fruta CTL presentaba valores de firmeza muy bajos, alrededor de los $25 \mathrm{~N}$ y un IC de +25 (Fig. 4). En la fruta que había recibido una única aplicación de $A_{3}$ los valores fueron intermedios. 

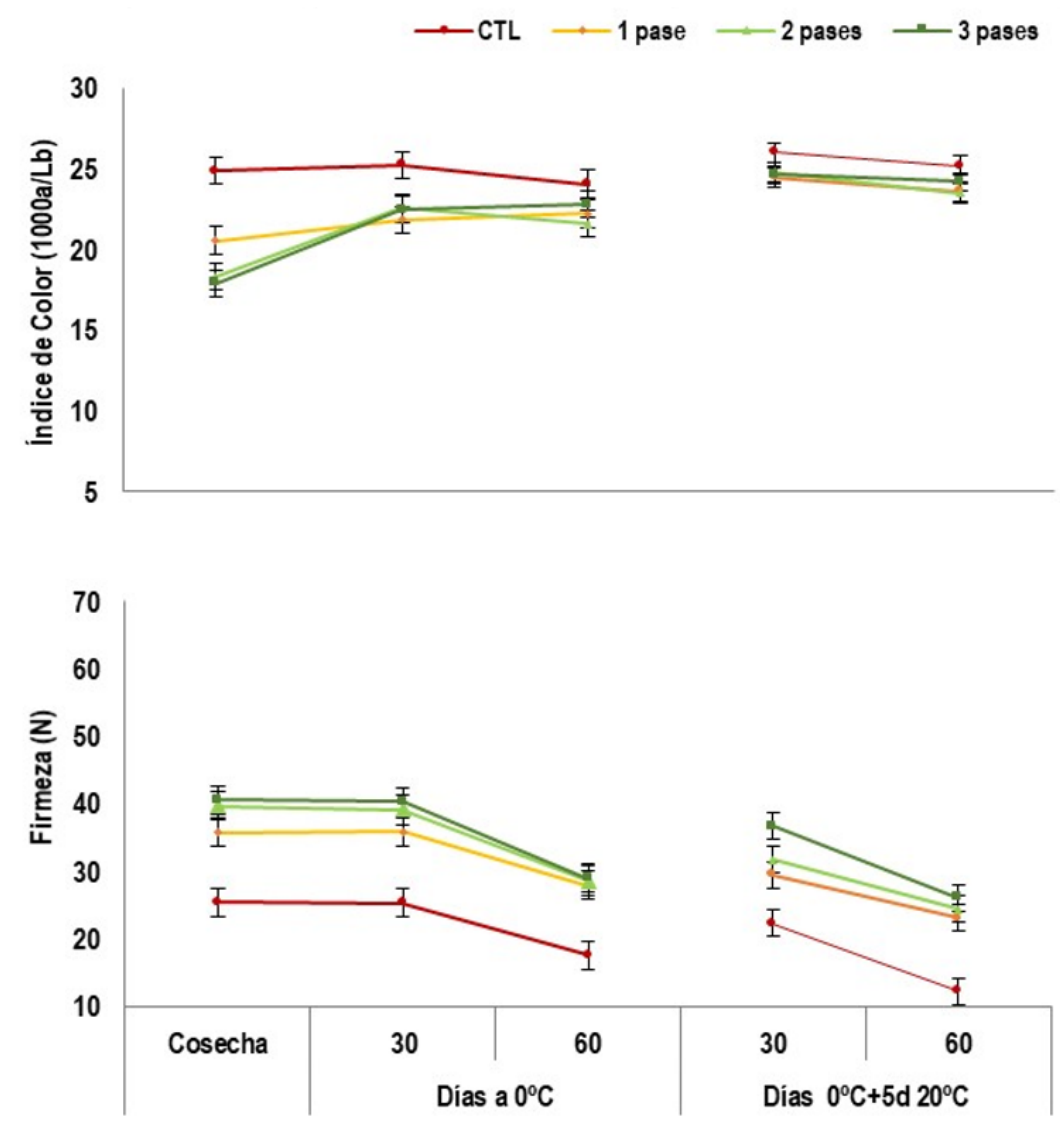

Fig. 4. Color (1000a/Lb) y firmeza (N) de frutos de caqui cv. Rojo Brillante tratados con $\mathrm{AG}_{3}$ (1, 2 ó 3 pases de tratamiento) y no tratados (CTL), en el momento de cosecha, tras una conservación de 30 y 60 días a $0{ }^{\circ} \mathrm{C}$ y una posterior comercialización de 5 días a $20{ }^{\circ} \mathrm{C}$. Fecha de cosecha: 5 de diciembre ( $3^{\text {a }}$ recolección). Las barras verticales representan los intervalos $L S D(P \leq 0,05)$.

La fruta CTL con un color naranja intenso ya en recolección, no experimentó grandes cambios de coloración durante los 30 y 60 días de conservación frigorífica ni tras las posteriores comercializaciones. En la fruta tratada con $\mathrm{AG}_{3}$ sí tuvo lugar un avance de la coloración, presentando valores de IC similares a los del CTL tras la comercialización que siguió a los 30 días de almacenamiento. Respecto a la firmeza, al igual que en las otras recolecciones no se observaron cambios destacables durante los 30 primeros días de conservación a bajas 
temperaturas, sin embargo, tras 60 días se observó una pérdida de firmeza en todos los tratamientos.

Cuando la fruta fue transferida a condiciones de comercialización tras 30 días de almacenamiento, en todos los casos se experimentó un ligero ablandamiento. La fruta CTL presentó valores cercanos a los $22 \mathrm{~N}$ y se detectó un ablandamiento acusado en la zona apical de algunos frutos (Figura 5), mientras que la fruta tratada con $\mathrm{AG}_{3}$ mostró firmezas superiores entre 30 y 38 $\mathrm{N}$, no detectándose síntomas de daño por frío en ninguno de los tratamientos.

Tras el periodo de comercialización que siguió a los 60 días de frigoconservación, el descenso de firmeza fue mucho más acusado. La fruta CTL presento una firmeza no comercial (cercana a $12 \mathrm{~N}$ ), mientras que toda la fruta tratada con $A G_{3}$, independientemente del número de pases aplicado, mostró valores cercanos a $24 \mathrm{~N}$. Hay que remarcar que estos valores son ligeramente superiores a los mostrados por la fruta cosechada en la segunda recolección. Esto puede deberse a un proceso de gomosidad que en ocasiones sufre la pulpa del fruto cuando es sometido a conservaciones frigoríficas prolongadas. La fruta en este momento manifestó síntomas de gelificación interna, que aunque fueron más acusados en la fruta CTL, podría comprometer también la comercialización de la fruta tratada con $\mathrm{AG}_{3}$ (Fig. 5). 


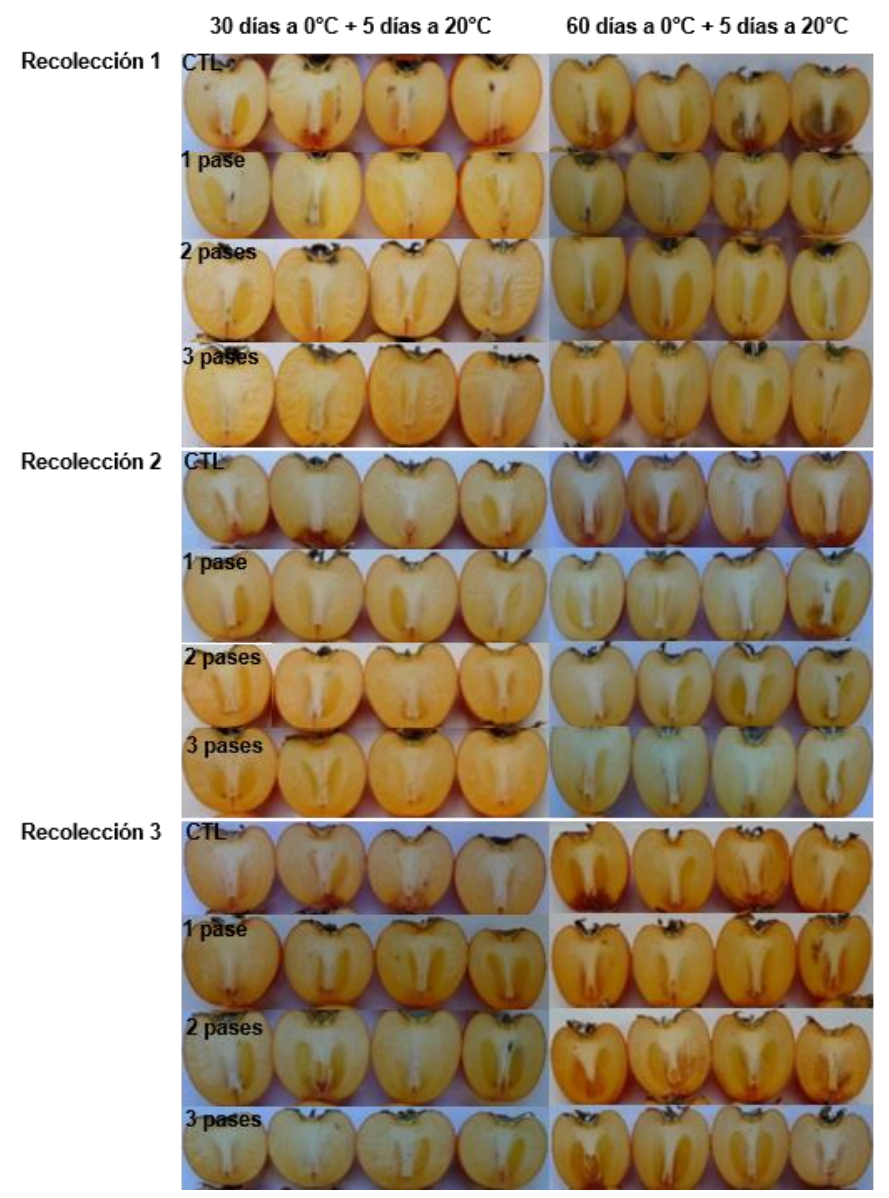

Fig. 5. Aspecto interno de los frutos de caqui cv. Rojo Brillante estudiados (CTL, 1, 2 ó 3 pases con $\mathrm{AG}_{3}$ ) en las recolecciones 1,2 y 3 tras 30 días a $0 \mathrm{C}+5$ días a $20{ }^{\circ} \mathrm{C}$ y 60 días a $0{ }^{\circ} \mathrm{C}+5$ días a $20^{\circ} \mathrm{C}$.

\section{Conclusiones}

El efecto de retraso de la maduración asociado a una aplicación de $\mathrm{AG}_{3}$ en el momento de viraje de color del caqui 'Rojo Brillante' se ve potenciado por la realización de una segunda aplicación al cabo de dos semanas. Este efecto se manifiesta en un atraso en el avance de la coloración del fruto y en la pérdida de firmeza natural en el árbol. Sin embargo, una tercera aplicación no presentó un efecto adicional respecto al mostrado por dos aplicaciones. 
Por otra parte, este estudio confirma que la aplicación de $\mathrm{AG}_{3}$ en precosecha en combinación con el tratamiento de Smartfresh ${ }^{\circledR}$ en postcosecha permite preservar una mayor calidad del caqui 'Rojo Brillante' durante la conservación respecto a la aplicación de únicamente Smartfresh ${ }^{\circledR}$. En las tres recolecciones realizadas, tras la frigoconservación más el periodo de comercialización, la fruta tratada con $A_{3}$ y sometida al tratamiento de Smartfresh ${ }^{\circledR}$ previo al almacenamiento, presentó mayores firmezas que la fruta CTL, tratada únicamente con Smartfresh ${ }^{\circledR}$.

En la primera recolección, realizada a mitad de noviembre, la aplicación de $\mathrm{AG}_{3}$, independientemente del número de pases realizados, permitió una conservación de hasta 60 días sin comprometer la calidad del fruto tras el periodo de comercialización.

En las recolecciones posteriores (finales de noviembre, principio de diciembre), el tratamiento de $\mathrm{AG}_{3}$ garantizó el mantenimiento de la calidad del fruto durante una conservación de hasta 30 días, presentando mayores firmezas la fruta con 2-3 pases en comparación con un único pase. En conservaciones de 60 días la calidad se vio comprometida por la manifestación de síntomas de daños por frío que fue un factor limitante para conservaciones tan prolongadas, incluso en la fruta tratada con $\mathrm{AG}_{3}$. Para conservaciones no superiores a 30 días, las aplicaciones múltiples resultaron en firmezas ligeramente más elevadas que una única aplicación, pero en todos los casos hubo un control de los daños por frío y la fruta presentó una calidad comercial.

\section{Agradecimientos}

Este estudio ha sido financiado por el Instituto Nacional de Tecnología Agraria y Alimentaria de España (INIA) con el apoyo de fondos FEDER a través de los proyectos RTA2013-00043-C02-01 y RTA2017-00045-C02-01. Ayoub Fathi Najafabadi agradece a INIA por la ayuda FPI-INIA \#43 (CPD2015-0151). Los autores agradecen a la empresa The Natural Hand por el apoyo técnico prestado para la realización de las aplicaciones de los tratamientos, así como la disponibilidad de las parcelas para llevar a cabo el estudio. 


\section{Bibliografía}

Agustí, M., Juan, M., Yagüe, B., Mesejo, C., Martínez-Fuentes, A., \& Almela, V. (2003). Tratamientos para retrasar la maduración del fruto del caqui (Dyospiros kaki L.). CV Agraria. 24, 27-33.

Agustí, M., Juan, M., Martínez-Fuentes, A., Mesejo, C., \& Almela, V. (2004). Calcium nitrate delays climacteric of persimmon fruit. Annals of Applied Biology. 144, 65-69. https://doi.org/10.1111/j.1744-7348.2004.tb00317.x

Arnal, L., \& Del Rio, M.A. (2004). Effect of cold storage and removal astringency on quality of persimmon fruit (Diospyros kaki, L.) cv. Rojo Brillante. Food Science and Technology International. 10 (3), 179-185. https://doi.org/10.1177/1082013204044824

Ben-Arie, R., Saks, Y., \& Sonego, L. (1996). Cell wall metabolism in gibberellintreated persimmon fruits. Plant Growth Regulation. 19, 25-33. https://doi.org/10.1007/BF00024399

Ben-Arie, R., Zhou, H.W., Sonego, L., \& Zutkhi Y. (1997). Plant growth regulator effects on the storage and shelf-life 'Triumph' persimmons. Acta Horticulturae. 436,

243-250. https://doi.org/10.17660/ActaHortic.1997.436.26

Besada, C., Arnal, L., \& Salvador, A. (2008). Improving storability of persimmon cv. Rojo Brillante by combined use of preharvest and postharvest treatments. Postharvest Biology and Technology. 50, 169-175. https://doi.org/10.1016/j.postharvbio.2008.05.013

Besada, C., Novillo, P., Navarro, P., \& Salvador, A. (2014). Effects of a low oxygen atmosphere with 1-MCP pre-treatment on preserving the quality of 'Rojo Brillante' and 'Triumph' persimmons during cold storage. Scientia Horticulturae. 179, 51-58. https://doi.org/10.1016/j.scienta.2014.09.015

Brackman, A., De Freitas, S.T., \& Pinto, J.A.V. (2004). Ripening control with 1methylcyclopropene on "Fuyu" persimmon in cold storage and controlled 
atmosphere. Revista da Faculdade de Zootecnia, Veterinária e Agronomia, Uruguaiana. 11, 123-134.

Girardi, C.L., Parussolo, A., Danieli, R., Corrent, A.R., \& Rombaldi, C.V. (2003). Conservation of persimmons fruit (Diospyros kaki, L.), cv. Fuyu with aplication of 1-methylyclopropene. Revista Brasileira de Fruticultura. 25, 54-56. https://doi.org/10.1590/S0100-29452003000100016

Kim, Y., \& Lee J. (2005). Extension of storage and shelf-life of sweet persimmon with 1-MCP. Acta Horticulturae. 685, 165-174. https://doi.org/10.17660/ActaHortic.2005.685.19

Novillo, P., Salvador, A., Navarro, P., \& Besada, C. (2015). Involvement of the redox system in chilling injury and its alleviation by 1-methylcyclopropene in 'Rojo Brillante' persimmon. HortScience. 50 (4), 570-576. https://doi.org/10.21273/HORTSCl.50.4.570

Tibola, C.S., Lucchetta, L., Zanuzo, M.R., da Silva, P.R., Ferri, V.C., \& Rombaldi, C.V. (2005). Inibição da ação do etileno na conservação de caquis (Diospyrus kaki L.) 'FUYU'. Revista Bra- sileira de Fruticultura. Jaboticabal, SP. 27, 36-39. http://dx.doi.org/10.1590/S0100-29452005000100011 


\title{
Chlorophyll fluorescence imaging as a tool to evaluate calyx senescence during ripening of persimmon fruit treated with gibberellic acid
}

\author{
Ayoub Fathi Najafabadi ${ }^{a}$, Cristina Besada ${ }^{a}$, Rebeca Gila , M $^{\mathrm{a}}$ \\ Angeles Calatayud ${ }^{b}$, Alejandra Salvador ${ }^{a}$

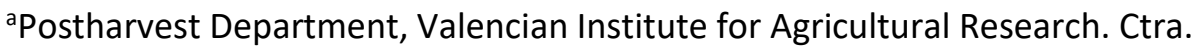 \\ Moncada Náquera Km. 4.5, 46113 Moncada, Valencia, Spain

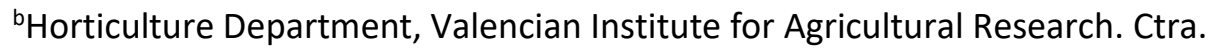 \\ Moncada Náquera Km. 4.5, 46113 Moncada, Valencia, Spain.
}

Reference: Under Review: Postharvest Biology and Technology 



\section{Abstract}

The effect of Gibberellic Acid (GA) on retarding loss of persimmon firmness and fruit coloration has been previously reported. Nevertheless, no information exists about the effect of this treatment on calyx senescence. In this study, Chlorophyll Fluorescence Imaging (CFI) was used as a tool to evaluate calyx senescence in persimmon fruits treated with GA. Physicochemical parameters in fruit and $\mathrm{CFI}$ parameters (Fo, Fm and Fv/Fm) in the calyx lobe were evaluated at three harvest times on fruit treated once or twice with $G A$, and fruit without treatment (Control). A decline in chlorophyll fluorescence parameters correlated with the senescence process that occurs in the calyx during fruit ripening. Spatial images heterogeneity in the measurements of $\mathrm{Fm} / \mathrm{Fv}$ explains the symptoms of senescence and necrosis that begin in the apical area of the calyx lobes and progress to the basal area. The GA, besides retarding fruit ripening, delays the senescence process of the calyx hence improving the external fruit quality. The CFI parameters measured in the calyx were correlated with the external color increase and the loss of firmness during fruit ripening. Consequently, these chlorophyll fluorescence parameters could become a potential non-intrusive tool to determine the time for persimmon harvesting.

Keywords: Calyx senescence, ripening, Fo, Fm, Fv/Fm, fruit quality 


\section{Introduction}

'Rojo Brillante' is an astringent persimmon cultivar which is cultivated mainly in Mediterranean countries such as Spain and Italy. Under Mediterranean agroclimatic conditions, the commercial fruit maturation is from mid-October to December. This short harvest period implies an important commercialization problem for growers and persimmon producers. Therefore, pre and postharvest treatments are usually applied to prolong the harvest period and to extend the shelf-life of the fruit once harvested.

One of the most studied preharvest treatments to delay the harvest time of some persimmon cultivars is Gibberellic Acid (GA) (Agustí et al., 2004; Besada et al., 2008). It has been reported that the application of GA, when the fruit show color-break, causes a delay in fruit maturity, postpones the green-toorange color change, enhances the erection of the sepal lobes and affects cell wall composition, retarding flesh softening (Ben-Arie et al., 1996, 1997; Agustí et al., 2003, 2004).

The external color and firmness of the fruit are the most important attributes to take into account in persimmon commercialization. Nevertheless, the state of the calyx is also an important fruit quality attribute, since in persimmon the calyx is a very characteristic part of the fruit from the visual point of view. Persimmon fruit possess a large green four-lobed calyx around the stem-end of the fruit that gets darker during fruit ripening, which is associated with a commercial quality loss. During calyx senescence, the desiccation and browning symptoms start from the apical part of the lobes toward the basal part. Calyx senescence in persimmon would be similar to leaf senescence in plants, which is related to the breakdown of the chloroplast and chlorophyll catabolism (Lim et al., 2007). In previous reports it has been studied that photosynthesis by calyx lobes may contribute to fruit development in persimmon (Yonemori et al., 1996; Nakano et al., 1998). Moreover, Woolf \& Ben-Arie (2011) reported that the calyx retains chlorophyll until harvest, and the fruit is dependent on it for gas exchanging into the fruit. Nevertheless, until now no information exists about the relationship between calyx senescence and physicochemical changes that occur in persimmon during fruit ripening, 
and if the pretreatments that delay ripening, such as GA, can affect the calyx senescence process.

Chlorophyll Fluorescence Imaging (CFI), is a rapid, inexpensive and nonintrusive technique that is being widely used for the evaluation of plant photosynthetic activity. CFI has revealed that photosynthetic activity within samples can be heterogeneous (Gorbe \& Calatayud, 2012). There are spatialtemporal variations in fluorescence parameters, caused by different stress factors, which can be visualized through $\mathrm{CFI}$, but cannot be detected by conventional fluorimeters. So, $\mathrm{CFI}$ is used for the detection of abiotic and biotic stresses such as nutrient and water deficiencies, extreme temperatures, and the effect of air pollution and herbicides on plants and fruits (Chaerle et al., 2007; Chen et al., 2009; Weber et al., 2017; Dong et al., 2019). Moreover, the efficiency of this method to determine the maturity and ripening stage of some fruits, such as papaya, guava and jujube, has been reported (Bron et al., 2004, 2005; Lu et al., 2012).

The amount of chlorophyll fluorescence emitted by the photosynthetically active chlorophyll molecules is closely connected with the integrity, activity, or inhibition and efficiency of the photosystem II (PSII) in green samples. A part of solar energy absorbed by chlorophylls can be used for photosynthesis; excess energy is emitted as heat or invisible chlorophyll fluorescence (Demmig-Adams et al., 1996). According to the Kautsky effect, when the chlorophyll-containing sample is illuminated with a low-energy modulated light (after a dark-adapted state) the fluorescence yield measured is termed Fo (minimal fluorescence). Illumination of the sample with a saturating light pulse allows the full reduction of all $Q_{A}$ and all PSII centers to be closed (Jee, 1995). This permits an increase in the yield of chlorophyll fluorescence and the attainment of the Fm level (maximum chlorophyll a fluorescence yield of a dark-adapted sample). The difference between $\mathrm{Fm}$ and $\mathrm{Fo}$ is known as variable fluorescence ( $\mathrm{Fv}=\mathrm{Fm}$ Fo), permitting the calculation of the maximum quantum yield of the chlorophyll fluorescence $\mathrm{Fv} / \mathrm{Fm}$, which is a measure of the efficiency in the energy transfer process and chloroplast activity (Rosenqvist \& Van Kooten, 2003). In this context, the application of the CFI technique could be used to 
provide information about the changes in the photosynthetic activity of the calyx during persimmon fruit ripening.

The aims of the present research were the following: 1) to study the effect of GA on calyx senescence, evaluating the changes in CFI parameters on different calyx parts at different fruit harvest times; 2) to determine the relationship between chlorophyll fluorescence parameters in calyx and fruit quality parameters.

\section{Materials and Methods}

The study was carried out at a commercial 'Rojo Brillante' persimmon orchard located in Albal, Valencia, Spain $\left(39^{\circ} 23^{\prime} 06.6^{\prime \prime} \mathrm{N} 0^{\circ} 25^{\prime} 13.7^{\prime \prime} \mathrm{W}\right)$ at an altitude of $10 \mathrm{~m}$ from sea level. One row of six trees, two trees as one replicate, were taken for each evaluated treatment. Each row was separated by another row that was not be taken into consideration to avoid crossed-contamination between GA treatments.

One row was sprayed with $\mathrm{GA}$, at a concentration of $30 \mathrm{LL} \mathrm{L}^{-1}$, when the fruit had a skin color index ( $C l=1000 a / L b, ~ ' L ', ' a$ ', 'b' Hunter parameters) close to 1.8 on October 10 (one GA treatment) (GA1). Another row was sprayed at the same time as GA1, and another GA treatment was applied fifteen days later, on October 25 (two GA treatments) (GA2). Finally, the third row was selected as a control (CTL) without any GA treatment.

Three harvests of 120 fruits per treatment (40 fruits per replicate) were carried out on November 13 (first harvest or H1), on November 27 (second harvest or $\mathrm{H} 2$ ) and on December 4 (third harvest or H3). After each harvest, the fruit were transported to the Instituto Valenciano de Investigaciones Agrarias ((IVIA) Moncada, Spain), where the following parameters were measured in the fruit: flesh firmness, pulp and skin color, soluble tannin content and ethylene and $\mathrm{CO}_{2}$ production. Ethylene and $\mathrm{CO}_{2}$ production were also determined in the calyx, once it had been carefully separated from the upper part of the fruit. Chlorophyll fluorescence parameters (Fv/Fm, Fo, Fm) were measured in lobes of the calyx and their images were obtained. 


\subsection{Physicochemical parameters}

The skin color, firmness and pulp color were individually determined over twenty fruits per replicate.

The skin color was evaluated by a Minolta colorimeter (Model CR-300 Ramsey, NY, USA) measuring two opposite sides of the fruit. Hunter parameters ' $L$ ' ' $a$ ' ' $b$ ' were measured, and the results were expressed as Color Index $(\mathrm{Cl}=$ $1000 \mathrm{a} / \mathrm{Lb}$ ), which reflects the color changes of persimmon fruit (Salvador et al., 2007).

Fruit firmness was measured on opposite equatorial sides by a texturometer (model 4301, Instron Corp., Canton, Mass., U.S.A.), using an 8-mm plunger after removing the fruit epicarp from the persimmon fruit. The crosshead speed during firmness determination was set at $10 \mathrm{~mm} / \mathrm{min}$. The values were shown as the maximum force in Newtons $(\mathrm{N})$ required to break the pulp.

To measure the pulp color, the fruits were cut in half and the two opposite equatorial fleshy parts were measured with the same colorimeter as the skincolor. The results were expressed as Color Index $=1000 \mathrm{a} / \mathrm{Lb}$ (Hunter parameters).

The soluble tannins (ST) in the pulp were evaluated on three samples of five fruits per treatment by the Folin-Denis method (Taira, 1996), as described by Arnal \& Del Río (2004). The results were expressed on a fresh weight basis (g $\left.\mathrm{kg}^{-1}\right)$.

$\mathrm{CO}_{2}$ and ethylene production were individually measured in four whole fruits, and also in four calyxes per treatment which were previously separated from the fruits according to Besada et al. (2016). Fruits and calyx samples were sealed in 1-L and $100 \mathrm{~mL}$ jars, respectively. The jars were kept for two hours at $20^{\circ} \mathrm{C}$. Then, one $\mathrm{mL}$ of air from the headspace was extracted with a BD Plastic pack syringe and injected into the gas chromatograph with a Poropak QS 80/100 column (model 2000, Perkin-Elmer, Norwalk, Conn, USA). A thermal conductivity detector determined $\mathrm{CO}_{2}$ concentration. Helium was used as the carrier gas at $9.2 \mathrm{psi}$. The injector, oven and detector temperatures were 115 , 35 and $150{ }^{\circ} \mathrm{C}$, respectively. A flame ionization detector was used to measure ethylene. Helium was the carrier gas at 8 psi. Injector, oven, and detector 
temperatures were 175,75 and $175{ }^{\circ} \mathrm{C}$, respectively. The concentration of gases was measured according to Novillo et al. (2016). The $\mathrm{CO}_{2}$ released from the fruits and calyxes was expressed as $\mathrm{mmol} \mathrm{kg}^{-1} \mathrm{~h}^{-1}$, while ethylene was expressed as $\mathrm{nmol} \mathrm{kg}^{-1} \mathrm{~h}^{-1}$.

\subsection{Measurement of chlorophyll fluorescence imaging parameters}

Ten calyxes were carefully removed from the upper part of the fruits from each repetition and two opposite lobes were selected to measure the chlorophyll fluorescence parameters using an imaging-PAM fluorometer (Walz, Effeltrich, Germany). The calyx lobes were placed in the dark for 10 min prior to measurement. The minimum chlorophyll fluorescence yield in the darkadapted Fo were determined using light pulses at a low frequency $(1 \mathrm{~Hz})$. The maximum fluorescence $\mathrm{Fm}$ was determined by applying a blue saturation pulse $(10 \mathrm{~Hz})$. The maximum quantum yield of PSII photochemistry, the Fv/Fm ratio, was determined as (Fm-Fo)/Fm, and images were captured for each fluorescence parameter. The PAM-software was used to select areas to determine chlorophyll fluorescence parameters for each calyx. Three areas were selected for each lobe: basal, middle and apical (Fig. 1) in order to evaluate spatial heterogeneity. For each area, the chlorophyll fluorescence parameters (Fo, Fm and $\mathrm{Fv} / \mathrm{Fm}$ ) were measured where pixel value images of the fluorescence parameters were displayed with the help of a false color code, ranging from black (0.000) through red, yellow, green, blue to pink (ending at 1.000) (Berger et al., 2004). Moreover, the Fo, Fm and Fv/Fm parameter values were also calculated for the complete surface of each calyx lobe. 


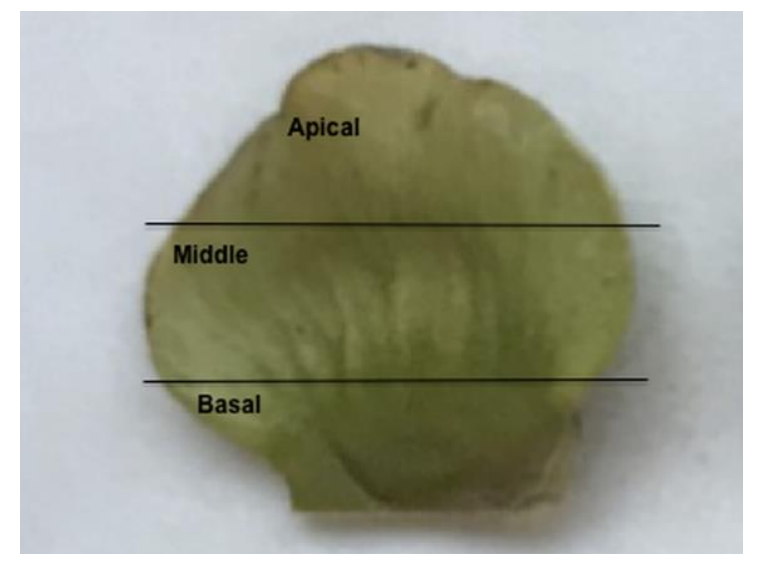

Fig. 1. Calyx lobe of persimmon cv. Rojo Brillante. Apical: outermost part of the lobe. Middle: equatorial lobe area. Basal: the closest area to the fruit.

\subsection{Statistical analysis}

Data were subjected to an analysis of variance based on two factors (harvest time $\times$ treatment). The mean values of the evaluated parameters were compared by the least significant difference test $(P \leq 0.05)$. The Statgraphics Centurion XVII.I software application was used for the statistical analysis (Manugistics Inc., Rockville, MD, USA). A Pearson correlation and simple linear regression were used to correlate the fruit quality attributes with the chlorophyll fluorescence parameters measured in the fruit calyx.

\section{Results and Discussion}

\subsection{Physicochemical parameters in the fruit}

The fruit of cultivar 'Rojo Brillante' are commercialized with a crisp-texture, so high firmness at harvest is crucial to preserve this quality parameter during the postharvest period (Salvador et al., 2007). At the time of the first harvest, the control fruit had values of $40 \mathrm{~N}$, significantly lower than GA1 and GA2 treated fruit which had similar values, close to $43 \mathrm{~N}$ (Fig. 2A). In the following harvests, the firmness reduction was highly influenced by the treatment. The control 
fruit exhibited a gradual decrease down to values of $23 \mathrm{~N}$ in the third harvest. In fruit from both GA treatments, no changes were observed in the second harvest, nevertheless, in the third one a greater decrease with significant differences was observed in the GA1 fruit, which achieved values of $30 \mathrm{~N}$ while GA2 exhibited the highest values of $37 \mathrm{~N}$. The effect of a preharvest treatment of GA on delaying on-tree firmness loss has been previously reported in persimmon cultivars such as 'Rojo Brillante' and 'Triumph' (Besada et al., 2008; Agustí et al., 2004; Ben Arie et al., 1996). This effect has been related to maintaining an organized cell wall and delaying changes in cell wall structure which accompany fruit softening (Ben Arie et al., 1996).
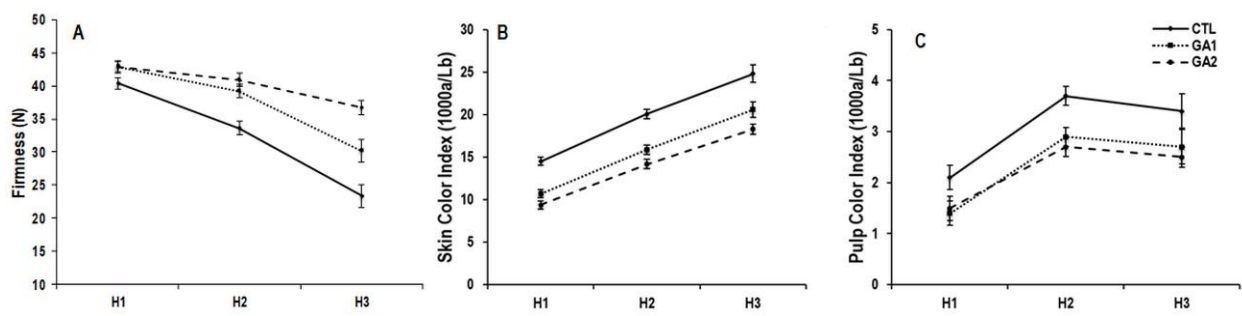

Fig. 2. Firmness (A), skin color index (B) and pulp color index (C) of persimmon cv. Rojo Brillante without any treatment (CTL), treated once with gibberellic acid (GA1) and treated twice with gibberellic acid (GA2) at the three harvest times ( $\mathrm{H} 1, \mathrm{H} 2$ and $\mathrm{H} 3$ ). Vertical bars represent the least significant difference (LSD) intervals ( $P \leq 0.05$ ).

An increase in skin fruit coloration was found in parallel to a reduction in firmness with the harvest advance (Fig. 2B). At the time of the first harvest, the control fruit were picked with an external color index of +14.5 , while fruit from both GA treatments showed significantly lower values, close to +10 . All the fruit showed a constant increase in color throughout harvest time, with the control fruit having the highest color indexes, followed by GA1 and GA2 fruit for each harvest performed. Color increase in persimmon during fruit maturation and ripening is related to chlorophyll degradation and carotenoid and lycopene accumulation (Forbus et al., 1991; Zhou et al., 2011, Novillo et 
al., 2016). In 'Rojo Brillante' persimmon, a strong negative correlation between skin color and firmness values during ripening has previously been reported (Salvador et al., 2006; Tessmer et al., 2016; Besada \& Salvador, 2018). Indeed, color measurements have been established as a usual non-destructive method to predict flesh firmness in 'Rojo Brillante' persimmon (Salvador et al., 2006, 2007). In the present work, the study of the correlations between skin color and flesh firmness revealed a significant negative correlation (-0.93) (data not shown).

Regarding pulp coloration, at first harvest, a significantly higher color index of +2.1 was found in the control fruit compared to the GA1 and GA2 fruit, which had similar values, close to +1.4 (Fig. $2 \mathrm{C}$ ). All the fruit exhibited a drastic pulp color increase in second harvest, and then remained without significant changes in the third harvest. The maximum internal color index was +3.7 in the control fruit, and close to +2.8 in fruit from the GA treatments, with no differences between GA1 and GA2. It has been reported that carotenoid compounds are mainly responsible for the flesh color of the persimmon fruit, and an increase in their content has been found during the ripening process (Bing et al., 2006; Novillo et al., 2016).

A significant characteristic of some persimmon cultivars is the astringency of fruit at harvest, due to the high soluble tannin content. During ripening, a gradual tannin insolubilization led to a progressive decline in soluble tannins with the consequent astringency reduction (Tessmer et al., 2016). In astringent persimmon cultivars, such as 'Rojo Brillante', at commercial maturity stages the soluble tannins remain at high concentrations in the flesh, and only at the last overripe stage, when the fruit is very soft, tannin insolubilization is complete, and no sensorial astringency is detected (Tessmer et al., 2016; Besada \& Salvador, 2018). In this study, at the time of the three harvests the fruit from all the treatments showed similar values between 4.3 and $4.9 \mathrm{~g} \mathrm{~kg}^{-1}$ (data not shown), which is the range reported in previous studies for this cultivar (Novillo et al., 2015, 2016).

With regard to $\mathrm{CO}_{2}$ production in the fruit, a significant decrease was observed from the first to the second harvest, with no differences in the third one (Table 1). The values detected were in the range previously reported for 'Rojo 
Brillante (Novillo et al., 2014, 2016). Nakano et al. (1997) reported that the fruit of cultivar 'Hiratanenashi' treated with GA showed less respiration compared to fruit without any treatment. Nevertheless, in this study no statistical differences among treatments were found.

No ethylene production was detected in any of the fruit from any of the treatments (data not shown). This coincides with other studies in which undetectable ethylene values were reported when fruit were harvested at similar maturity stages to those in this study (Salvador et al., 2007; Novillo et al., 2014, 2016).

Table 1. $\mathrm{CO}_{2}$ production in the fruit and ethylene production in the fruit calyx of persimmon cv. Rojo Brillante without any treatment (CTL), treated once with gibberellic acid (GA1) and treated twice with gibberellic acid (GA2) at the three harvest times $(\mathrm{H} 1, \mathrm{H} 2$ and $\mathrm{H} 3)$. Different letters in each parameter indicate statistical differences $(P \leq 0.05)$.

\begin{tabular}{ccccccc}
\hline & \multicolumn{2}{c}{ Fruit $\mathrm{CO}_{2}\left(\mathrm{mmol} \mathrm{kg}^{-1} \mathrm{~h}^{-1}\right)$} & \multicolumn{3}{c}{ Calyx Ethylene $\left(\mathrm{nmol} \mathrm{kg}^{-1} \mathrm{~h}^{-1}\right)$} \\
\hline & $\mathrm{H} 1$ & $\mathrm{H} 2$ & $\mathrm{H} 3$ & $\mathrm{H} 1$ & $\mathrm{H} 2$ & $\mathrm{H} 3$ \\
$\mathrm{CTL}$ & $0.38 \mathrm{a}$ & $0.28 \mathrm{~b}$ & $0.22 \mathrm{~b}$ & 0 & 0 & $20.98 \mathrm{a}$ \\
$\mathrm{GA} 1$ & $0.33 \mathrm{a}$ & $0.25 \mathrm{~b}$ & $0.27 \mathrm{~b}$ & 0 & 0 & $14.73 \mathrm{~b}$ \\
$\mathrm{GA} 2$ & $0.33 \mathrm{a}$ & $0.24 \mathrm{~b}$ & $0.26 \mathrm{~b}$ & 0 & 0 & $7.58 \mathrm{c}$ \\
\hline
\end{tabular}

\subsection{Calyx senescence. Chlorophyll fluorescence parameters}

Figure 3 illustrates the visual aspect of the calyx lobes of the control fruit (without treatment), and the fruits treated once (GA1) and twice (GA2) with GA in the three harvests carried out. At first harvest, although no great differences can be appreciated among treatments, the control lobes showed symptoms of slight dehydration over all in the apical part of the lobes. In the second harvest, the control fruit presented severe symptoms of senescence that became more evident in the third harvest, when the lobes appear completely desiccated and necrotic. The calyx lobes from the GA treated fruit did not show senescence symptoms until the third harvest, when slight 
browning symptoms were observed, mainly in the apical part. These symptoms were more accentuated in the GA1-fruit than in the GA2-fruit.
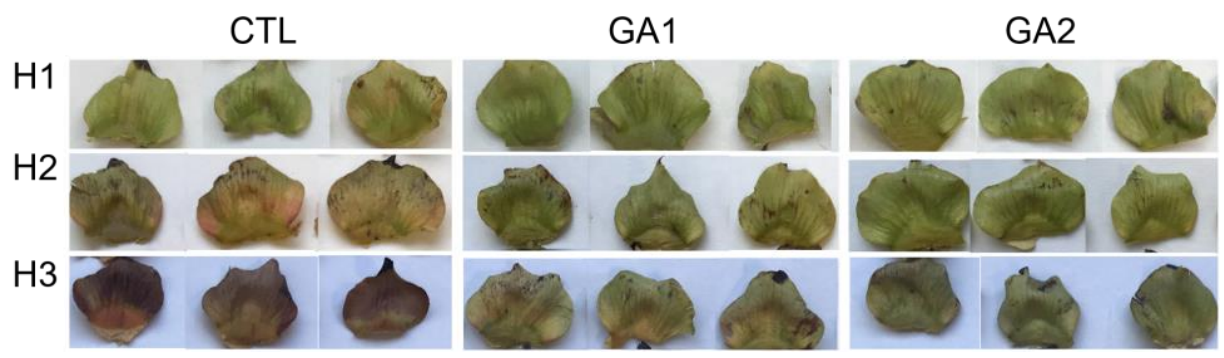

Fig. 3. Visual aspect of the calyx lobes of persimmon cv. Rojo Brillante without any treatment (CTL), treated once with gibberellic acid (GA1) and treated twice with gibberellic acid (GA2) at the three harvest times ( $\mathrm{H} 1, \mathrm{H} 2$ and $\mathrm{H} 3$ ).

When the ethylene was measured on the fruit calyx, it was not detected for any treatment in the fruit picked at first and second harvest (Table 1). However, for the third harvest values of $0.47 \mu \mathrm{L} \mathrm{kg}^{-1} \mathrm{~h}^{-1}$ were recorded in the control fruit, while significantly lower values of $0.33 \mu \mathrm{Lg}^{-1} \mathrm{~h}^{-1}$ and $0.17 \mu \mathrm{Lg}^{-1}$ $\mathrm{h}^{-1}$ were found in the GA1 and GA2 fruit, respectively. Nakano et al. (2003) reported that ethylene biosynthesis of the persimmon calyx in fruit detached from the tree was almost zero at harvest, but it increased during fruit ripening. In our study, the ethylene concentration was only detected in the calyx at third harvest, and according to Nakano et al. (2003) the highest ethylene values were found in fruit with a more advanced maturity stage (CTL-fruit).

Chlorophyll fluorescence parameters were measured in the calyx lobes from the control and GA treated fruit (Fig. 4). The Fv/Fm parameter is usually used to evaluate the maximal quantum yield associated with the efficiency of the PSII reaction centers in the dark-adapted state samples. At first harvest, the mean $\mathrm{Fv} / \mathrm{Fm}$ value of the calyx lobe, considering its entire area, was similar, close to 0.7, for the fruit from all the treatments (Fig. 4A). In the fruit submitted to both GA treatments, the values remained without change at 
second harvest, and then exhibited a decrease at third harvest, down to values of 0.50 and 0.58 in GA1 and GA2, respectively. Nevertheless, in the control fruit a drastic drop was exhibited in the second harvest, down to values of 0.07 , with no changes in the last harvest.

Regarding the minimal fluorescence yield (Fo) in the dark-adapted state, at first harvest calyx lobes from the control and GA1 fruit showed similar values (0.06), while significantly higher values were found in the GA2 fruit (Fig. 4B). The Fo values decreased drastically in the control fruit after second harvest, showing values of 0.02 in the third harvest. In the case of the GA1 and GA2 fruit, the Fo values remained constant until the second harvest and then decreased, reaching similar values, close to 0.04 , in the third harvest. A similar tendency in the decrease of the maximal fluorescence yield $(\mathrm{Fm})$ was found with the harvest advance (Fig. 4C).
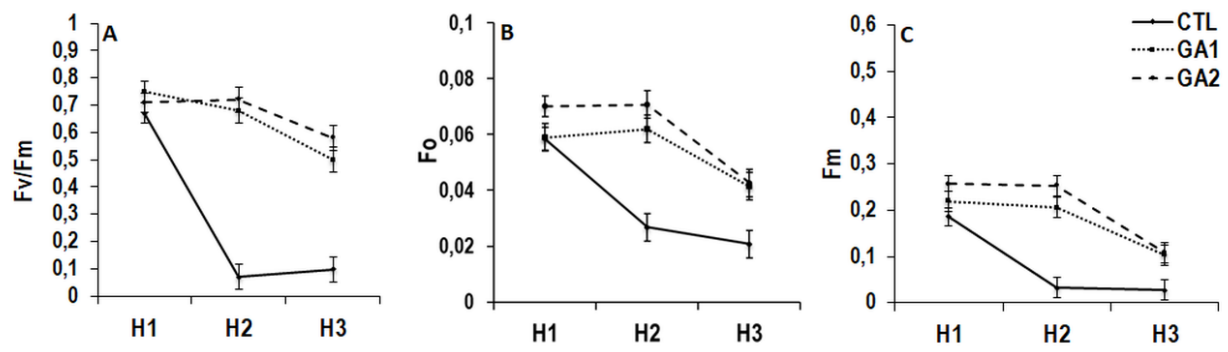

Fig. 4. Chlorophyll fluorescence image parameters (Fv/Fm, Fo, Fm) of the whole calyx lobes of persimmon cv. Rojo Brillante without any treatment (CTL), or treated once with gibberellic acid (GA1) and treated twice with gibberellic acid (GA2) at the three harvest times ( $\mathrm{H} 1, \mathrm{H} 2$ and $\mathrm{H} 3)$. Vertical bars represent the least significant difference (LSD) intervals $(P \leq 0.05)$.

The present study revealed a different spatial heterogeneity in CFI parameters in the calyx lobes. In Figure 5, a CFI example of the calyx lobe from the control fruit at the three harvest times is shown. In all the harvests, higher values of $\mathrm{Fv} / \mathrm{Fm}$ and Fm were observed in the basal area of the calyx lobes, while Fo 
values displayed similar values in all areas. In the GA treated fruit, a similar spatial heterogeneity in the calyx lobes was observed (images not shown).

Fv/Fm

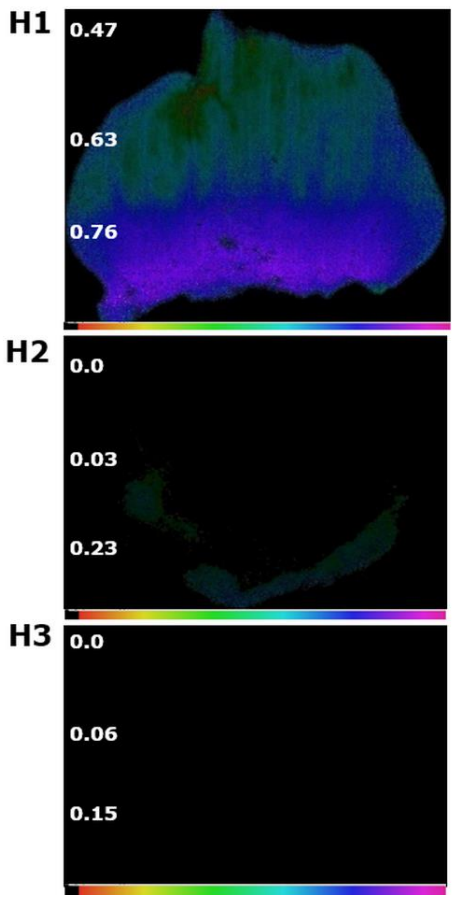

Fo
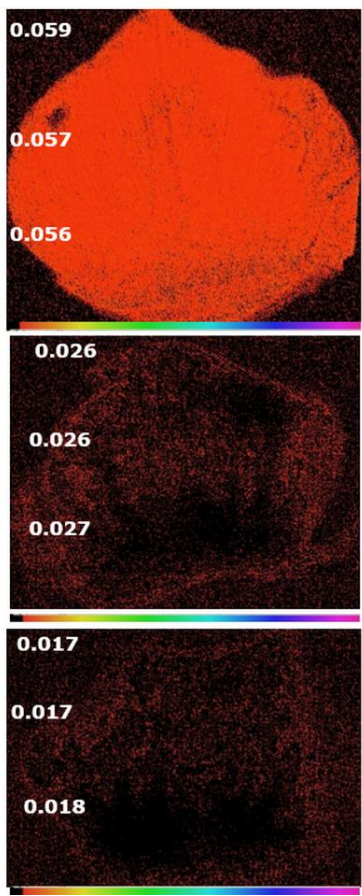

Fm
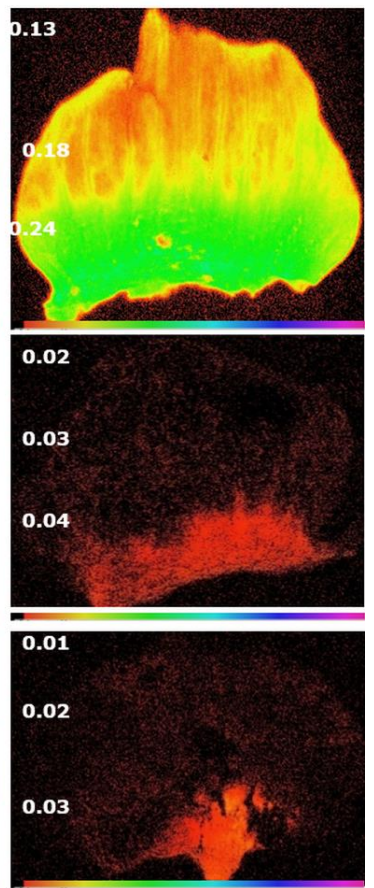

Fig. 5. Chlorophyll fluorescence image parameters (Fv/Fm, Fo, Fm) in three different areas of the calyx lobe (basal, middle and apical) in the control fruit (CTL) after the three harvests ( $\mathrm{H} 1, \mathrm{H} 2$ and $\mathrm{H} 3$ ). The left numbers in the figures are the Fv/Fm, Fo and $\mathrm{Fm}$ values in the three areas. The false color code depicted at the bottom of each image ranges from 0.000 (black) to 1.000 (pink). The figure represent the images of a single calyx lobe were taken each harvest period.

Figure 6 shows the values of Fv/Fm, Fo and Fm measured separately in the three areas of the calyx lobe (basal, middle and apical). The changes in Fv/Fm during harvest time were different depending on the area measured. At first 
harvest, the values in the basal area were close to 0.8 in all fruits. In the middle area, Fv/Fm was 0.63 for the control fruit and close to 0.7 for both GA treatments, with no differences among treatments. Lower values were found in the apical area, where the control exhibited values of 0.47 , significantly lower than GA1 and GA2 with values close to 0.65 . For the control fruit, Fv/Fm exhibited a drastic drop in the three lobe areas at second harvest, then remained unchanged for the third one. The apical area had the lowest values (close to 0 ), followed by the middle area (close to 0.03 ) and the basal area (close to 0.22 ) in the second and third harvest. In the case of fruit treated with $\mathrm{GA}$, the decline in Fv/Fm after the first harvest was much less marked than in the control, and a different trend was observed in the three areas of the calyx lobe. In the basal area, a very slight decrease in $\mathrm{Fv} / \mathrm{Fm}$ was exhibited without any differences between $\mathrm{GA} 1$ and $\mathrm{GA2}$, with values in third harvest close to 0.67. Nevertheless, in the middle area, while in GA2 fruits $\mathrm{Fv} / \mathrm{Fm}$ remained without any changes in the second harvest and then decreased to values of 0.57 in the third harvest, in GA1 fruits these changes were more pronounced, showing values of 0.46 in the last harvest. In the apical area, lower Fv/Fm values were found and the differences between GA1 and GA2 were more accentuated. 

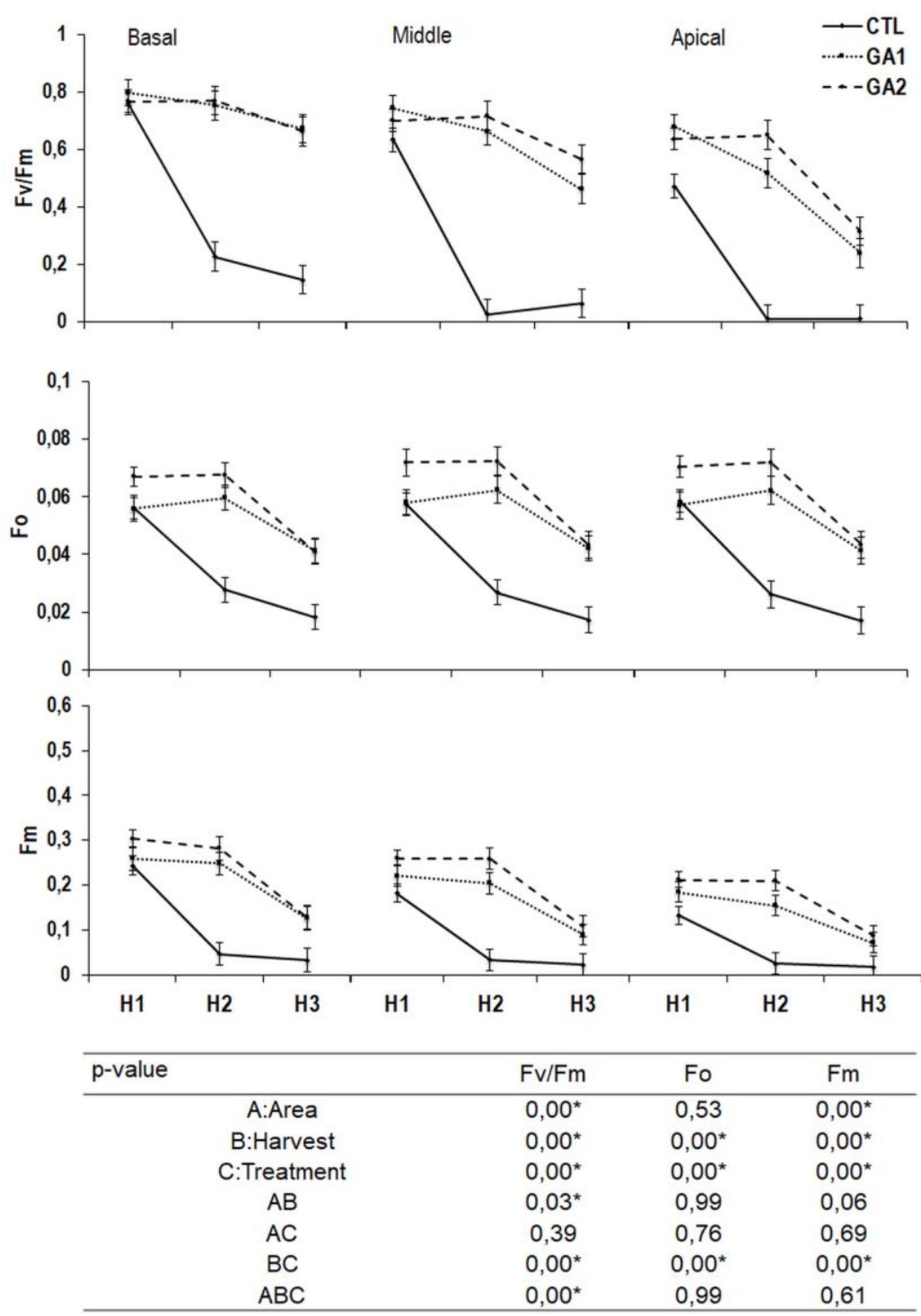

Fig. 6. Chlorophyll fluorescence image parameters (Fv/Fm, Fo, Fm) measured in three areas of the calyx lobe (basal, middle and apical) of persimmon cv. Rojo Brillante without any treatment (CTL), treated once with gibberellic acid (GA1) and treated twice with gibberellic acid (GA2) at the three harvest times ( $\mathrm{H} 1, \mathrm{H} 2$ and $\mathrm{H} 3)$. Vertical bars represent the least significant difference (LSD) intervals $(P \leq 0.05)$ for each area of the calyx lobe. The asterisk $\left({ }^{*}\right)$ shows the significant difference $(P \leq 0.05)$. 
Regarding Fo, no differences were found among the areas of the calyx. The three areas of the GA2-fruit showed the highest values in the first harvest, close to 0.07 without any changes in the second harvest, then decreased in the third harvest to values close to 0.04 . The control and GA1 fruit exhibited similar Fo values in the first harvest, close to 0.06 . Nevertheless, while in the control an important drop was shown in the following harvests, in GA1 no changes were detected in the second harvest, and then there was a decrease in the third harvest to similar values to those found in GA2 (0.04).

In the $\mathrm{Fm}$ parameter, similar to $\mathrm{Fv} / \mathrm{Fm}$, the basal area exhibited higher values than the middle, and the lowest values were found in the apical area. The basal area of the control and GA1 had Fm values close to 0.25 in the first harvest, while greater values (0.3) were detected in GA2. The control fruit exhibited an important decrease in the following harvests to values of 0.04 . GA1 and GA2 suffered a much less marked descent, achieving similar Fm values, close to 0.13 in the third harvest. In the middle and apical areas, a similar tendency was observed, nevertheless the differences among treatments were smaller. In the last harvest, the control and GA treated fruits achieved values close to 0.02 and 0.08 , respectively.

According to our results, chlorophyll fluorescence parameters (Fv/Fm, Fo and $\mathrm{Fm}$ ) would explain the visual senescence process that the calyx undergoes throughout the harvest period, as well as the differences found among treatments, as seen in Figure 3. Thus, the higher drop in Fv/Fm, Fo and Fm parameters observed in the control fruit compared to the GA-treated fruit is related to the earlier onset of senescence symptoms in the calyx of the control fruit. In the same way, the lower chlorophyll fluorescence values found in the apical area compared to other areas of the lobe, can be associated with a faster senescence process in this area, compared to the middle and basal areas. CFI is well suited to visualize heterogeneity in plant response to stress; localized responses can be clearly revealed against a background of unaffected plant tissue (Chaerle et al., 2007).

The Fv/Fm ratio during dark to light transition in dark-adapted samples depends on Fo and Fm fluorescence. Throughout the harvest times (from $\mathrm{H} 1$ to $\mathrm{H} 3$ ), we observed that $\mathrm{Fv} / \mathrm{Fm}$ values decline, which were attributed to a 
decline in the level of $\mathrm{Fm}$ and Fo. The decrease in $\mathrm{Fm}$ indicates that the photochemistry of PSII, and its ability to reduce the primary acceptor $Q_{A}$, could be affected by the senescence mechanism (Gorbe \& Calatayud, 2012), whereas the decrease in Fo was probably due to chlorophyll degradation, and also to the degree of chloroplast membrane injury due to senescence processes (Bron et al., 2004; Wingler et al., 2004). A common characteristic associated with leaf senescence is the increase in cell membrane degradation (Lim et al., 2007), which leads to chloroplast senescence, in which the cell membranes lose their physical integrity, decreasing photosynthetic capacity and consequently leading to a decline in the fluorescence parameters. Therefore, the higher values of fluorescence parameters found in the calyx of the fruit treated with $G A$, especially in $G A 2$, compared to the control fruits, would be related to the effect of GA on delaying the degradation of the cell wall and chlorophyll breakdown in leaves and fruits reported in previous studies (Ben arie et al., 1996; Rosenvasser et al., 2006; Li et al., 2010).

The differences in $\mathrm{Fm}$ and $\mathrm{Fv} / \mathrm{Fm}$ values found among the different areas of the calyx lobes indicate a heterogeneous spatial-damage distribution, with the highest values in the basal lobe, decreasing in the areas furthest from the fruit. This fact could be related to the transfer of water and nutrients from the fruit to the calyx lobe, which allows the photosynthetic reactions to be maintained in the closest area to the fruit. Exposure of the plant to the GA regulator caused a great increase in the photochemical efficiency of PSII in the calyx in all areas, indicating a suppression, or delay, in leaf senescence. Several authors have demonstrated that exogenous application of $\mathrm{GA}$ increases $\mathrm{Fv} / \mathrm{Fm}$ in pepper leaves (Ouzounidou et al., 2010), in okra (Ilias et al., 2007) and geranium (Currey et al., 2013). The application of GA has been associated with its capacity to preserve photosynthesis and delay chlorophyll loss (Jordi et al., 1994).

On the other hand, the relationship between chlorophyll fluorescence parameters in calyx and fruit quality parameters was studied. The study of the correlations revealed a significant Pearson correlation between chlorophyll fluorescence parameters of the calyx, and both the color and firmness of the fruit (Table 2). All the chlorophyll fluorescence parameters studied were 
negatively correlated to the external fruit color, while a positive correlation was found with flesh firmness. In both cases, the highest correlation coefficient was detected with $\mathrm{Fm}$ values. Considering the three areas of the calyx lobe separately, Fm measured in the basal area was the most correlated. Fv/Fm also displayed a significant correlation with external color and flesh firmness. In this case, the highest correlation coefficient was detected with $\mathrm{Fv} / \mathrm{Fm}$ values of the apical area. For Fo, the values obtained in the basal area were also highly correlated with both of these quality parameters.

Table 2. Equations and correlations between external color index $(\mathrm{Cl})$ or firmness $(\mathrm{F})$ of the fruit and the chlorophyll fluorescence parameters (Fv/Fm, Fm, Fo) of the calyx lobe and three areas of the calyx (basal, middle and apical).

\begin{tabular}{llclr}
\hline & \multicolumn{1}{c}{ Color Index (Cl) } & & Firmness (F) \\
\hline Fv/Fm Calyx lobe & $\mathrm{Cl}=24.22-14.59 \times \mathrm{Fv} / \mathrm{Fm}$ & -0.767 & $\mathrm{~F}=26.28+19.61 \times \mathrm{Fv} / \mathrm{Fm}$ & 0.778 \\
\hline Fv/Fm Basal & $\mathrm{Cl}=25.93-15.25 \times \mathrm{Fv} / \mathrm{Fm}$ & -0.754 & $\mathrm{~F}=23.80+20.80 \times \mathrm{Fv} / \mathrm{Fm}$ & 0.776 \\
Fv/Fm Middle & $\mathrm{Cl}=23.54-13.89 \times \mathrm{Fv} / \mathrm{Fm}$ & -0.775 & $\mathrm{~F}=27.20+18.70 \times \mathrm{Fv} / \mathrm{Fm}$ & 0.787 \\
Fv/Fm Apical & $\mathrm{Cl}=22.53-15.43 \times \mathrm{Fv} / \mathrm{Fm}$ & -0.834 & $\mathrm{~F}=28.73+20.30 \times \mathrm{Fv} / \mathrm{Fm}$ & 0.827 \\
\hline Fm calyx lobe & $\mathrm{Cl}=23.87-47.56 \times \mathrm{Fm}$ & -0.853 & $\mathrm{~F}=27.31+60.40 \times \mathrm{Fm}$ & 0.817 \\
\hline Fm Basal & $\mathrm{Cl}=24.20-41.53 \times \mathrm{Fm}$ & -0.861 & $\mathrm{~F}=26.90+52.67 \times \mathrm{Fm}$ & 0.824 \\
Fm Middle & $\mathrm{Cl}=23.57-46.01 \times \mathrm{Fm}$ & -0.854 & $\mathrm{~F}=27.64+58.72 \times \mathrm{Fm}$ & 0.822 \\
Fm Apical & $\mathrm{Cl}=23.21-54.85 \times \mathrm{Fm}$ & -0.840 & $\mathrm{~F}=28.16+69.47 \times \mathrm{Fm}$ & 0.802 \\
\hline Fo Calyx Lobe & $\mathrm{Cl}=24.63-156.46 \times \mathrm{Fo}$ & -0.677 & $\mathrm{~F}=25.31+218.54 \times \mathrm{Fo}$ & 0.713 \\
\hline Fo Basal & $\mathrm{Cl}=27.64-231.37 \times \mathrm{Fo}$ & -0.805 & $\mathrm{~F}=21.95+305.76 \times \mathrm{Fo}$ & 0.803 \\
Fo Middle & $\mathrm{Cl}=26.45-200.04 \times \mathrm{Fo}$ & -0.775 & $\mathrm{~F}=23.36+267.51 \times \mathrm{Fo}$ & 0.781 \\
Fo Apical & $\mathrm{Cl}=26.27-198.64 \times \mathrm{Fo}$ & -0.766 & $\mathrm{~F}=23.44+268.99 \times \mathrm{Fo}$ & 0.782 \\
\hline
\end{tabular}

\section{Conclusion}

In this study, we propose a novel approach to understand the calyx senescence process of persimmon fruit during ripening though the study of CFI parameters 
(Fv/Fm, Fo, Fm). Our results showed that a decline in the chlorophyll fluorescence parameters measured in the calyx lobes was correlated with the senescence process that occurs in the calyx of persimmon fruit during their ripening, which was highly affected by GA treatment. Spatial heterogeneity in the measurements of $\mathrm{Fm} / \mathrm{Fv}$ explains the symptoms of senescence and necrosis that begin in the apical area of the calyx lobes and progress to the basal area.

The decline of all CFI parameters measured in the fruit calyx correlated with the increase in external fruit color, and the decrease in flesh firmness, which the fruit undergoes during its ripening. Consequently, treatment with $G A$, applied to delay the fruit harvest, besides retarding fruit ripening, delays the senescence process of the calyx and improves its external quality.

The chlorophyll fluorescence parameters of the calyx could become a potential non-intrusive tool to determine the time for harvesting and the quality of persimmon.

\section{Acknowledgements}

This research was funded by Instituto Nacional de Investigación y Tecnología Agraria y Alimentaria (INIA) and Fondo Europeo de Desarrollo Regional (FEDER), through Project RTA2017-00045-C02-01. Ayoub Fathi Najafabadi thanks the INIA for grant FPI-INIA \#43 (CPD2015-0151).

\section{References}

Agustí, M., Juan, M., Yagüe, B, Mesejo, C., Martínez-Fuentes, A., \& Almela, V. (2003). Tratamientos para retrasar la maduración del fruto del caqui (Dyospiros kaki L.). CV Agraria 24, 27-33.

Agustí, M., Juan, M., Martínez-Fuentes, A., Mesejo, C., \& Almela, V. (2004). Calcium nitrate delays climateric of persimmon fruit. Annals of Applied Biology. 144, 65-69. https://doi.org/10.1111/j.1744-7348.2004.tb00317.x 
Arnal, L., \& Del Rio, M.A. (2004). Effect of cold storage and removal astringency on quality of persimmon fruit (Diospyros kaki, L.) cv. Rojo Brillante. Food Science and Technology International.10 (3), 179-185. https://doi.org/10.1177/1082013204044824

Ben-Arie, R., Saks, Y., \& Sonego, L. (1996). Cell wall metabolism in gibberellintreated persimmon fruits. Plant Growth Regulation. 19, 25-33. https://doi.org/10.1007/BF00024399

Ben-Arie, R., Zhou, H.W., Sonego, L., \& Zutkhi, Y. (1997). Plant growth regulator effects on the storage and shelf-life 'Triumph' persimmons. Acta Horticulturae. 436,

243-250. https://doi.org/10.17660/ActaHortic.1997.436.26

Berger, S., Papadopoulus, M., Schreiber, U., Kaiser, W., \& Roitsch, T. (2004). Complex regulation of gene expression, photosynthesis and sugar levels by pathogen infection in tomato. Plant Physiology. 122, 419-428. https://doi.org/10.1111/j.1399-3054.2004.00433.x

Besada, C., Arnal, L., \& Salvador, A. (2008). Improving storability of persimmon cv. Rojo Brillante by combined use of preharvest and postharvest treatments. Postharvest Biology and Technology. 50, 169-175. https://doi.org/10.1016/j.postharvbio.2008.05.013

Besada, C., Gil, R., Bonet, L., Quiñones, A., Intrigliolo, D., \& Salvador, A. (2016). Chloride stress triggers maturation and negatively affects the postharvest quality of persimmon fruit. Involvement of calyx ethylene production. Plant Physiology and Biochemistry. 100, 105-112. https://doi.org/10.1016/j.plaphy.2016.01.006

Besada C., \& Salvador A. (2018). Postharvest Biology and Technology of Persimmon. In: Mir S., Shah M., Mir M. (eds). Postharvest Biology and Technology of Temperate Fruits. Springer, Cham, pp. 371-393. https://doi.org/10.1007/978-3-319-76843-4_16 
Bing, Y., HuaLong, X., \& Ping, L., (2006). Content and chemical composition of carotenoids in persimmon fruit. Chinese Agricultural Science Bulletin. 10, 227-280

Bron, I.U., Ribeiro, R.V., Azollini, M., Jacomino, A.P., \& Machado, E.C. (2004). Chlorophyll fluorescence as a tool to evaluate the ripening of 'Golden' papaya fruit. Postharvest Biology and Technology. 33, 163-173. http://doi.org/10.1016/j.postharvbio.2004.02.004

Bron, I.U., Ribeiro, R.V., Azzolini, M., Machado, E. C., \& Jacomino, A. P. (2005). Chlorophyll fluorescence emission and its relation to skin color and firmness during ripening of guava fruit. Fruits. 60(1), 25-32. https://doi.org/10.1051/fruits:2005009

Chaerle, L., Leinonen, I., Jones, H.G., \& Van der Straeten, D. (2007). Monitoring and screening plant populations with combined thermal and chlorophyll fluorescence imaging. Journal of Experimental Botany. 58, 773-784. https://doi.org/10.1093/jxb/erl257

Chen, C.P., Frank, T.D., \& Long, S.P. (2009). Is a short, sharp shock equivalent to long-term punishment? Contrasting the spatial pattern of acute and chronic damage to soybean leaves via chlorophyll fluorescence imaging. Plant, Cell \& Environment. 32, 327-335. https://doi.org/10.1111/j.13653040.2008.01923.x

Currey, C. J., Lopez, R.G., Rapaka, V.K., Faust, J.E., Runkle, E.S. (2013). Exogenous applications of benzyladenine and gibberellic acid inhibit lower leaf senescence of geraniums during propagation. HortScience. 48 (11), 1352-1357. https://doi.org/10.21273/HORTSCl.48.11.1352

Demmig-Adams, B., Adams III, W., Barker, D., Logan, B., Bowing, D., Verhoeven, A. (1996). Using chlorophyll fluorescence to assess the fraction of absorbed light allocated to thermal dissipation of excess excitation. Physiologia Plantarum. 98, 253-264. https://doi.org/10.1034/j.13993054.1996.980206.x 
Dong, Z., Men, Y., Li, Z., Zou, Q., \& Ji, J. (2019). Chlorophyll fluorescence imaging as a tool for analyzing the effects of chilling injury on tomato seedlings. Scientia Horticulturae. 246, 490-497. https://doi.org/10.1016/j.scienta.2018.11.019

Forbus, W. R., Payne, J. A., \& Senter, S. D. (1991). Nondestructive evaluation of Japanese persimmon maturity by delayed light emission. Journal of Food Science. 56(4), 985-988. https://doi.org/10.1111/j.13652621.1991.tb14622.x

Gorbe, E., \& Calatayud, A. (2012). Applications of chlorophyll fluorescence imaging technique in horticultural research: a review. Scientia Horticulturae. 138, 24-35. https://doi.org/10.1016/j.scienta.2012.02.002

Ilias, I., Ouzounidou, G., Giannakoula, A., \& Papadopoulou, P. (2007). Effects of gibberellic acid and prohexadione-calcium on growth, chlorophyll fluorescence and quality of okra plant. Biologia plantarum. 51, 575-578. https://doi.org/10.1007/s10535-007-0126-5

Jee, G. (1995). Sixty-Three Years Since Kautsky: Chlorophyll a Fluorescence. Australian Journal of Plant Physiology. 22, 131-160. https://doi.org/10.1071/PP9950131

Jordi, W., Pot, C.S., Stoopen, G.M., \& Schapendonk A.H.C.M. (1994). Effect of light and gibberellic acid on photosynthesis during leaf senescence of Alstroemeria cut flowering stems. Physiologia Plantarum. 90, 293-298. https://doi.org/10.1111/j.1399-3054.1994.tb00390.x

Li, J.R., Yu, K., Wei, J.R., Ma, Q., Wang, B.Q., Yu, D. (2010). Gibberellin retards chlorophyll degradation during senescence of Paris polyphylla. Biologia Plantarum. 54, 395-399. https://doi.org/10.1007/s10535-010-0072-5

Lim, P.O., Kim, H.J., \& Nam, H.G. (2007). Leaf senescence. Annual Review of Plant Biology. 58 , 115-136. https://doi.org/10.1146/annurev.arplant.57.032905.105316 
Lu, H., Lou, H., Zheng, H., Hu, Y., \& Li, Y. (2012). Nondestructive evaluation of quality changes and the optimum time for harvesting during jujube (Zizyphus jujube Mill. cv. Changhong) fruits development. Food and Bioprocess Technology. 5, 2586-2595. https://doi.org/10.1007/s11947011-0640-5

Nakano, R., Yonemori, K., Sugiura, A., \& Kataoka, I. (1997). Effect of gibberellic acid and abscisic acid on fruit respiration in relation to final swell and maturation in persimmon. Acta Horticulturae. 436, 203-214. https://doi.org/10.17660/ActaHortic.1997.436.23

Nakano, R., Yonemori, K., \& Sugiura, A. (1998). Fruit respiration for maintaining sink strength during final swell at growth stage III of persimmon fruit. Journal of Horticultural Science and Biotechnology. 73, 341-346. https://doi.org/10.1080/14620316.1998.11510983

Nakano, R, Ogura, E., Kubo, Y., \& Inaba, A. (2003). Ethylene biosynthesis in detached young persimmon fruit is initiated in calyx and modulated by water loss from the fruit. Plant Physiology. 131, 276-286.

Novillo, P., Salvador, A., Magalhaes, T., \& Besada, C. (2014). Deastringency treatment with $\mathrm{CO} 2$ Induces oxidative stress in persimmon fruit. Postharvest Biology and Technology. 92, 16-22. https://doi.org/10.1016/j.postharvbio.2013.12.019

Novillo, P., Salvador, A., Navarro, P., Besada, C. (2015). Involvement of the redox system in chilling injury and its alleviation by 1-methylcyclopropene in 'Rojo Brillante' persimmon. HortScience. 50 (4), 570-576. https://doi.org/10.21273/HORTSCI.50.4.570

Novillo, P., Salvador, A., Crisosto, C., Besada, C. (2016). Influence of persimmon astringency type on physico-chemical changes from the green stage to commercial harvest. Scientia Horticulturae. 206, 7-14. https://doi.org/10.1016/j.scienta.2016.04.030 
Ouzounidou, G., Ilias, I.F., Giannakoula, A., \& Papadopoulou, P. (2010). Comparative study on the effects of various plant growth regulators on growth, quality and physiology of Capsicum annuum L. Pakistan Journal of Botany. 42, 805-814

Rosenqvist, E., \& Van Kooten, O. (2003). Chlorophyll Fluorescence: A general description and nomenclature, in: Kluwer academic publishers (Eds.). Practical applications of chlorophyll Fluorescence in plantbiology, pp. 3178. https://doi.org/10.1007/978-1-4615-0415-3_2

Rosenvasser, S., Mayak, S., \& Friedman H. (2006). Increase in reactive oxygen species (ROS) and in senescence-associated gene transcript (SAG) levels during dark-induced senescence of Pelargonium cuttings, and the effect of gibberellic acid. Plant Science. 170 (4), 873-879. https://doi.org/10.1016/j.plantsci.2005.12.010

Salvador, A., Arnal, L., Carot, J.M., Carvalho, C.P., \& Jabaloyes, J.M. (2006). Influence of different factors on firmness and color evolution during the storability of persimmon cv. 'Rojo Brillante'. Journal of Food Science. 71, 169-175. https://doi.org/10.1111/j.1365-2621.2006.tb08921.x

Salvador, A., Arnal, L., Besada, C., Larrea, V., Quiles, A., \& Pérez-Munuera, I. (2007). Physiological and structural changes during ripening and deastringency treatment of persimmon fruit cv. 'Rojo Brillante'. Postharvest Biology and Technology. 46 (2), 181-188. https://doi.org/10.1016/j.postharvbio.2007.05.003

Taira S. (1996). Astringency in Persimmon. In: Linskens H.F., Jackson J.F. (Eds.). Modern Methods of Plant Analysis, Fruit Analysis. Springer-Verlang, Berlin, pp. 97-110. https://doi.org/10.1007/978-3-642-79660-9_6

Tessmer, M.A., Besada, C., Hernando, I., Appezzato-da-Glória, B., Quiles, A., \& Salvador, A. (2016). Microstructural changes while persimmon fruits mature and ripen. Comparison between astringent and non-astringent 
cultivars. Postharvest Biology and Technology. 120, 52-60. https://doi.org/10.1016/j.postharvbio.2016.05.014

Weber, J.F., Kunz, C., Peteinatos, G.G., Santel, H.J., \& Gerhards, R. (2017). Utilization of chlorophyll fluorescence imaging technology to detect plant injury by herbicides in sugar beet and soybean. Weed Technology. 31(4), 523-535. https://doi.org/10.1017/wet.2017.22

Wingler, A., Mare`s, M., \& Pourtau, N. (2004). Spatial patterns and metabolic regulation of photosynthetic parameters during leaf senescence. New Phytologist. 161, 781-789. https://doi.org/10.1111/j.14698137.2004.00996.x

Woolf, A.B., \& Ben Arie, R. (2011). Persimmon (Diospyros kaki L.). In: Yahia, E.M. (Ed.). Postharvest Biology and Technology of Tropical and Subtropical Fruits. Wood-head Publishing, Cambridge, UK, pp. 166-193. https://doi.org/10.1533/9780857092618.166

Yonemori, K., Itai, A., Nakano, R., \& Sugiura, A. (1996). Role of calyx lobes in gas exchange and development of persimmon fruit. Journal of the American Society for Horticultural Science. 121(4), 676-679. https://doi.org/10.21273/JASHS.121.4.676

Zhou, C., Zhao, D., Sheng, Y., Tao, J., \& Yang, Y. (2011). Carotenoids in fruits of different persimmon cultivars. Molecules. 16, 624-636. https://doi.org/10.3390/molecules16010624 

CHAPTER V

\title{
Effect of storage conditions on quality of persimmon produced under organic conditions
}

\author{
Alejandra Salvador, Ayoub Fathi Najafabadi, Rebeca Gil, \\ Pilar Navarro, Cristina Besada
}

Postharvest Technology Center. Instituto Valenciano de Investigaciones Agrarias. Valencia. Spain.

Reference: Acta Horticulturae. 1256. 2019, 195-202. ISHS, Proc. VI International Conference Postharvest Unlimited (Oct, 2017). Eds.: D. Valero et al. https://doi.org/10.17660/ActaHortic.2019.1256.27 



\begin{abstract}
The cold storage of persimmon required a pretreatment with 1-MCP in order to delay chilling injury manifestation. However, the use of this ethylene inhibitor is not allowed in the case of persimmon produced under organic conditions. Thus, it is necessary to optimize the storage conditions, taking into account not only temperature and storage duration but also factors such as maturity stage at harvest and the application of the deastringency treatment. In this study, organically produced persimmons were harvested at different maturity stages throughout the season, and they were stored at low $\left(0^{\circ} \mathrm{C}\right)$ and moderate temperature $\left(15^{\circ} \mathrm{C}\right)$ for up to four weeks. Two different moments of application of the deastringency treatment with high $\mathrm{CO}_{2}$ concentrations were assayed (immediately after harvest or after the storage periods). Our results showed that the storage of fruit harvested with firmness values lower than 30 $\mathrm{N}$ was not possible due to the important softening that took place after harvest. Fruit harvested with higher firmness (30-45 N) maintained an acceptable quality for two or three weeks depending of the storage conditions. Both the storage temperature and the moment of application of $\mathrm{CO}_{2}$ deastringency treatment were observed to be decisive factors in the final quality of the fruit. Here we discuss the optimum conditions to store organic persimmons depending on the maturity stage.
\end{abstract}

Keywords: chilling injury, softening, flesh gelling, $\mathrm{CO}_{2}$ treatment, astringency 


\section{Introduction}

In the last two decades, the production of 'Rojo Brillante' persimmon in Spain has increased 10-fold, from 30.000 Tn to more than $300.000 \mathrm{Tn}$. Due to the short harvest season of this cultivar, from October to December, the storage of the fruit is necessary in order to supply the markets according to the demand.

The most regularly applied system to prolong the postharvest life of perishable vegetables is refrigeration. Although the standard recommended storage temperature for persimmon fruit is $0{ }^{\circ} \mathrm{C}$ (MacRae, 1987; Crisosto, 2004), the most of the cultivars are sensitive to low temperatures, and they develop physiological disorders (chilling injury) when exposed at a temperature below a critical temperature (Testoni, 2002; MacRae, 1987; Collins \& Tisdell, 1995; Arnal \& Del Río, 2004). This is the case of 'Rojo Brillante' persimmons, which manifest chilling injury symptoms when stored at temperatures below $11^{\circ} \mathrm{C}$ (Arnal et al., 2004). The main chilling injury symptoms of this variety are textural changes, a drastic loss of firmness and flesh gelling, which are manifested when the fruit is transferred from low to moderate temperatures (Besada et al., 2014; Novillo et al., 2015). 1-Methylcyclopropene (1-MCP), an inhibitor of ethylene perception, has been shown to reduce chilling injury symptoms in a large number of persimmon cultivars, included 'Rojo Brillante'. Nowadays, the application of 1-MCP treatment before storage is a common practice in order to preserve the quality of 'Rojo Brillante' persimmon during refrigeration. However, this treatment is not allowed in the case of the fruits certified as 'organic persimmon', which is an important limitation for fruit storage.

In this context, it is necessary to optimize the storage conditions in order to preserve the fruit quality of organic produced persimmons. To do this, it is important take into account that 'Rojo Brillante' is an astringent cultivar, and therefore fruits have to be submitted to postharvest deastringency treatments before commercialization. The treatment commercially used is based on submitting the fruit to $95 \% \mathrm{CO}_{2}, 24 \mathrm{~h}$ at $20{ }^{\circ} \mathrm{C}$ and its effectiveness has been reported to be affected by the fruit maturity stage as well as the previous storage conditions. 
The objective of this study was to determine the optimum conditions to store organic produced persimmon. To this end, the effect on fruit quality of the storage temperature $\left(0{ }^{\circ} \mathrm{C}\right.$ and $15^{\circ} \mathrm{C}$ ) and duration (up to one month), the stage of maturity at harvest and the moment of application of the deastringency treatment (immediately after harvest or after the storage periods) was evaluated.

\section{Materials and Methods}

Persimmon fruit produced under organic practices were harvested in Belgida (Valencia) at the beginning (Harvest 1) and at the end of October (Harvest 2). At each harvest time fruit from three different growers were collected. After harvest, the fruit were taken to the Instituto Valenciano de Investigaciones Agrarias (IVIA), where they were carefully selected to avoid damages. Then, fruit from each grower were divided in 36 homogenous lots of 20 fruits each one. Half of the lots were directly transferred to the storage chambers: nine lots were stored at $0{ }^{\circ} \mathrm{C}$, and other nine at $15^{\circ} \mathrm{C}$. The other half of the lots were submitted to the $\mathrm{CO}_{2}$ deastringency treatment applied in standard conditions $\left(95 \% \mathrm{CO}_{2}-24 \mathrm{~h}-2{ }^{\circ} \mathrm{C}\right)$. After the treatment fruit was kept at ambient temperature for $12 \mathrm{~h}$ and then was transferred to the storage chambers at $0{ }^{\circ} \mathrm{C}$ (9 lots) and $15{ }^{\circ} \mathrm{C}$ (9 lots). After 15,23 and 30 days of storage, three lots of each type were removing from the chambers. One of the lots was directly analyzed, while the other two lots were kept at $5{ }^{\circ} \mathrm{C}$ for four days in order to simulate a trailer transportation period and then a posterior shelf-life period of 5 days at $20^{\circ} \mathrm{C}$. In the case of that fruit that has been stored when astringent $\left(\mathrm{CO}_{2}\right.$ treatment not applied before storage), the deastringency treatment was applied after each storage period (15, 23 and 30 days), before transferring the fruit to transportation conditions.

Therefore, four different conditions of storage were evaluated: 1) $\mathrm{CO}_{2}$ treatment + Storage at $0{ }^{\circ} \mathrm{C}\left(\mathrm{CO} 2-0{ }^{\circ} \mathrm{C}\right.$-fruit); 2) $\mathrm{CO}_{2}$ treatment + Storage at 15 ${ }^{\circ} \mathrm{C}\left(\mathrm{CO}_{2}-15{ }^{\circ} \mathrm{C}\right.$-fruit), 3) Storage at $0{ }^{\circ} \mathrm{C}+\mathrm{CO}_{2}$ treatment $\left(0{ }^{\circ} \mathrm{C}-\mathrm{CO}_{2}\right.$-fruit $\left.), 4\right)$ Storage at $15{ }^{\circ} \mathrm{C}+\mathrm{CO}_{2}$ treatment $\left(15^{\circ} \mathrm{C}-\mathrm{CO}_{2}\right.$-fruit). 
At harvest, after each storage period (15, 23 and 30 days), after the transportation period and after the subsequent shelf-life periods, the quality of the fruit was evaluated by taking the following measurements: colour, firmness, internal disorders, soluble tannins and sensory evaluation of astringency.

Deastringency treatment was carried out in closed containers which contained $95 \% \mathrm{CO}_{2}$ for $24 \mathrm{~h}$ at $20{ }^{\circ} \mathrm{C}$ and $90 \%$ R.H. These conditions were established by passing a stream of air containing $95 \% \mathrm{CO}_{2}$ through the containers.

Skin colour was evaluated using a Minolta Colorimeter (Model CR-300, Ramsey, NY, USA), on samples of 20 fruit. ' $L$ ', ' $a$ ', ' $b$ ' Hunter parameters were measured and results were expressed as a skin colour index, as described by Jiménez-Cuesta et al. (1981). Colour index=(1000a)/(Lb).

Flesh firmness was determined with a Texturometer Instron Universal Machine model 4301 (Instron Corp., Canton, MA, USA), using an $8 \mathrm{~mm}$ flat plunger. Fruit firmness values are an average from 20 fruit. Results are expressed as the load in newtons $(\mathrm{N})$ required for breaking the flesh of the fruit on opposite sides after peel removal.

Soluble tannins were evaluated using the Folin-Denis method (Taira, 1995), as described by Arnal \& Del Río (2004); the results are expressed in \% (FW). The astringency level of the fruit was also estimated by sensory evaluation. This evaluation was performed using composite samples of five (peeled and sliced) fruit from each replicate. A trained panel of 8-10 people who were familiar with this cultivar was asked to evaluate astringency. A 5-point scale was used, where $5=$ high astringency and $1=$ no astringency. Samples were presented to members of the panel in trays labelled with random 3-digit codes and served at room temperature $\left(25 \pm 1^{\circ} \mathrm{C}\right)$. The judges had to taste several segments of each sample in order to compensate, as far as possible, for biological variation of the material. Milk was provided for palate-rinsing between samples. 


\section{Results and discussion}

Unlikely the traditional method for removing astringency based on over-ripen the fruit, the application of the $\mathrm{CO}_{2}$ deastringency treatment allows to remove the astringency of 'Rojo Brillante' persimmons while preserving their firmness. Thus, the flesh firmness is one of the main attributes to control during the storage and commercialization period. Although commercial quality standards in Spain do not include specific requirements regarding persimmon firmness, it has been assumed that the minimum firmness for commercialization is $10 \mathrm{~N}$ (Besada et al., 2008), and this has been also the limit adopted in this study.

\section{Harvest 1}

Fruit harvested at the beginning of October from the growers 1 and 2 showed a similar stage of maturity at harvest (firmness values of 43 and $41 \mathrm{~N}$ respectively, and colour index of $\mathrm{Cl}=+10$ ); however, fruit from grower 3 showed a more advanced stage of maturity, with firmness values of $25 \mathrm{~N}$ and external colour of +23 (Fig. 1). Accordingly, fruit from growers 1 and 2 showed a very similar behaviour throughout the studied period. During the storage at 0 ${ }^{\circ} \mathrm{C}$, both fruit previously treated with $\mathrm{CO}_{2}\left(\mathrm{CO}_{2}-0{ }^{\circ} \mathrm{C}\right.$-fruit) and fruit not previously treated $\left(0{ }^{\circ} \mathrm{C}-\mathrm{CO}_{2}\right.$-fruit) maintained high firmness values close to those at harvest, although the application of the deastringency treatment was linked to slightly lower firmness values. When the fruit that have been stored astringent $\left(0{ }^{\circ} \mathrm{C}-\mathrm{CO}_{2}\right.$-fruit) was submitted to the $\mathrm{CO}_{2}$ treatment and transferred to the transportation conditions $\left(4\right.$ days at $5{ }^{\circ} \mathrm{C}$ ), the firmness decreased importantly to values lower than those of fruit that has been treated before the storage. After the shelf-life periods, an important loss of firmness was detected in both treatments; this softening was more accused in $\mathrm{CO}_{2}-{ }^{\circ}{ }^{\circ} \mathrm{C}$-fruit than in $0{ }^{\circ} \mathrm{C}-\mathrm{CO}_{2}$-fruit, which was associated with the manifestation of flesh gelling. Thus, after the shelf-life that followed 15 days storage, while $0{ }^{\circ} \mathrm{C}-\mathrm{CO}_{2-}$ fruit showed firmness values of $10 \mathrm{~N}$, the $\mathrm{CO}_{2}-{ }^{\circ}{ }^{\circ} \mathrm{C}$-fruit displayed values as low as $3 \mathrm{~N}$. As the storage period progressed, the flesh gelling observed after the shelf-life was increasingly more accused in $\mathrm{CO}_{2}-0{ }^{\circ} \mathrm{C}$-fruit and become also evident in $0{ }^{\circ} \mathrm{C}-\mathrm{CO}_{2}$-fruit, all the fruit showing unacceptable firmness. The evaluation of soluble tannins and the sensory evaluation of the astringency 
revealed that the $\mathrm{CO}_{2}$ treatment was completely effective when applied before and after storing the fruit at $0{ }^{\circ} \mathrm{C}$.

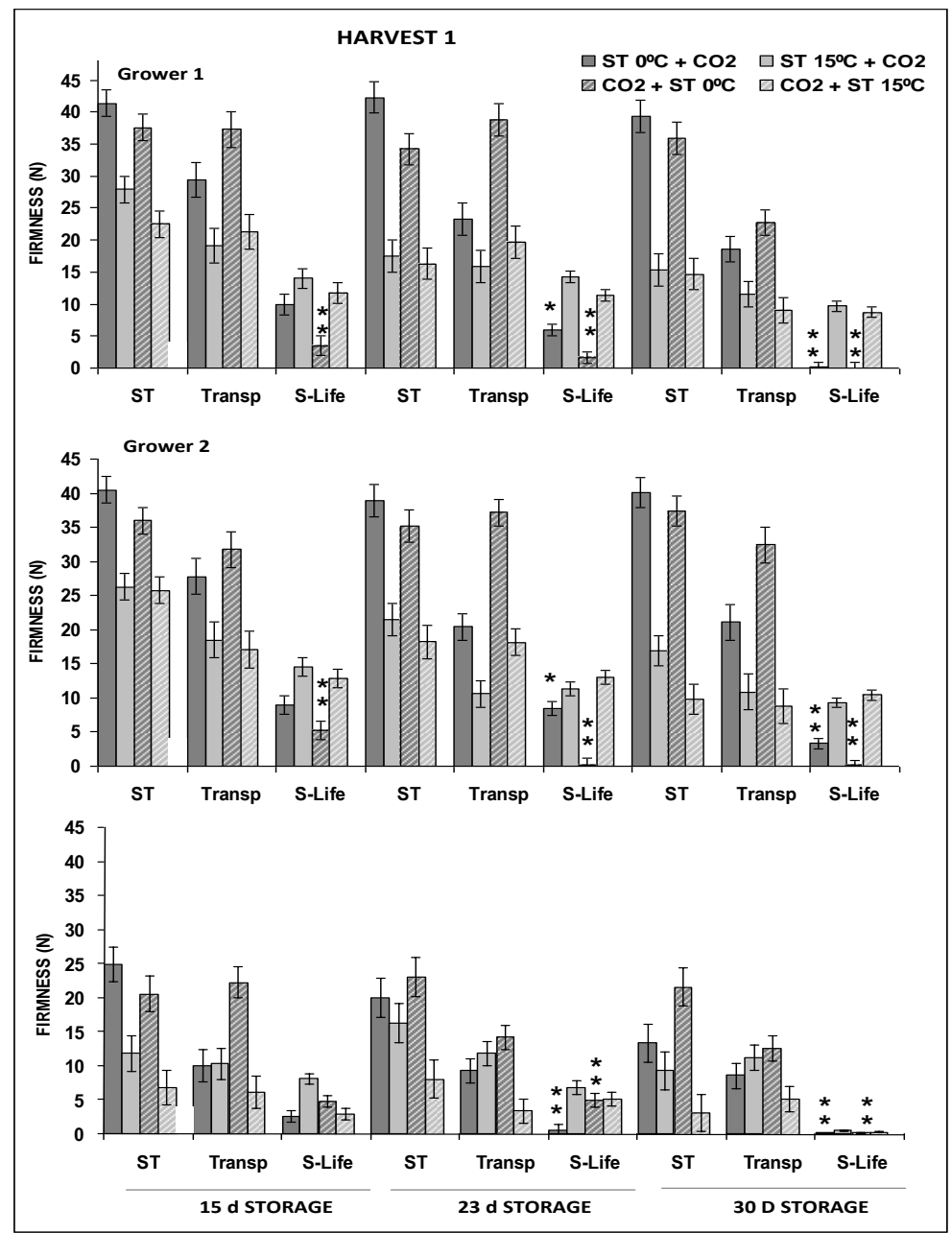

Fig. 1. Effect of the storage temperature $\left(0{ }^{\circ} \mathrm{C}\right.$ and $\left.15{ }^{\circ} \mathrm{C}\right)$ and the moment of application of the $\mathrm{CO}_{2}$ deastrignency treatment (before or after the storage period) on the firmness of 'Rojo Brillante' persimmon harvested at the beginning of October and stored for up to 1 month. (ST: storage; Transp: transportation period of 4 days at $5{ }^{\circ} \mathrm{C}$; S-Life: shelf-life period of 5 days at $20^{\circ} \mathrm{C}$ ). One asterisk indicates "slight-medium flesh gelling" and two asterisk indicate "severe flesh gelling". 
When the fruit was stored at $15^{\circ} \mathrm{C}$, a gradual loss of firmness was observed as the storage period advanced. The transfer of the fruit to temperature of transportation resulted on a slight decrease of firmness; however a more important softening was associated with the shelf-life period. In general, no relevant differences of firmness were detected between $\mathrm{CO}_{2}-15{ }^{\circ} \mathrm{C}$-fruit and 15 ${ }^{\circ} \mathrm{C}-\mathrm{CO}_{2}$-fruit. Both types of fruit showed commercial firmness, between 10-15 $\mathrm{N}$, after the shelf-life that followed 15 and 23 days of storage. However the soluble tannins measurement and the sensory evaluation revealed significant differences in the level of astringency of the fruit. The $\mathrm{CO}_{2}$-treatment applied immediately after harvest led to a reduction of soluble tannins to values of $0.03 \%$ (data not shown), and the panellists reported absence of astringency. However, when it was applied after the different storage periods $\left(15{ }^{\circ} \mathrm{C}-\mathrm{CO}_{2}-\right.$ fruit), the treatment was effective only after 15 days of storage. After 23 days, the effectiveness of the treatment was not complete and as longer was the storage period before treating fruit, as higher was the level of astringency that remained after the treatment. Thus, the panellists detected "slight" and "middle astringency" respectively (data not shown) when fruit was treated after 23 and 30 days of storage.

Fruit from grower 3, with lower firmness values at harvest, suffered an important decline of firmness after harvest. After the shelf-life that followed the storage for 15 days, the fruit showed firmness values lower than the commercial limit. This important decrease of firmness had place irrespective of the storage temperature or the moment of $\mathrm{CO}_{2}$ application. Unlike that observed in fruit from grower 1 and 2, in which flesh gelling was detected in $\mathrm{CO}_{2}-0{ }^{\circ} \mathrm{C}$-fruit after 15 days of storage, the chilling injury symptoms were only detected after 23 days of storage in fruit from grower 3 . This is in accordance with previous studies that have reported that 'Rojo Brillante' shows greater sensitiveness to chilling injury at early stage of maturity than at advanced stage of maturity (Salvador et al., 2006). On the other hand, as observed for grower 1 and 2, the deastringency treatment lost effectiveness when was applied to fruit previously stored at $15{ }^{\circ} \mathrm{C}$. In this case, the loss of effectiveness was detected even after 15 days of storage. Salvador et al. (2008) reported that this 
fact is associated with a loss of the initial flesh structure which makes difficult the diffusion of the $\mathrm{CO}_{2}$ inside the fruit.

\section{Harvest 2}

The stage of maturity of the fruit harvested at the end of October is reflected by the following values of firmness and colour: grower 1 ( $37 \mathrm{~N}$ and $\mathrm{Cl}=+17$ ), grower 2 (40 N and $\mathrm{Cl}=+15$ ) and grower 3 (33 N and $\mathrm{Cl}=+21$ ) (Fig. 2).

The results showed that all the fruit from harvest 2 showed a very similar behaviour to that described at harvest 1 for fruit from growers 1 and 2 . That is, the application of $\mathrm{CO}_{2}$ treatment before storing fruit at $0{ }^{\circ} \mathrm{C}$ resulted in non marketable fruit due to the manifestation of flesh gelling after 15 days of storage. However, fruit stored at $0{ }^{\circ} \mathrm{C}$ when astringent and then submitted to the deastrigency treatment preserved commercial quality for two weeks. It must be notice that in the particular case of the grower 2, with fruit showing the highest values of firmness at harvest $(40 \mathrm{~N})$, the fruit showed an acceptable quality even after three weeks of storage.

With respect to the storage at $15{ }^{\circ} \mathrm{C}$, the application of the deastringency treatment before storage was completely effective and the $\mathrm{CO}_{2}-15{ }^{\circ} \mathrm{C}$-fruit showed firmness higher than $10 \mathrm{~N}$ after 23 days of storage. However, the $\mathrm{CO}_{2}$ treatment was not effective when applied after the storage periods. Such loss of effectiveness resulted in non marketable fruit even after 15 days of storage. 


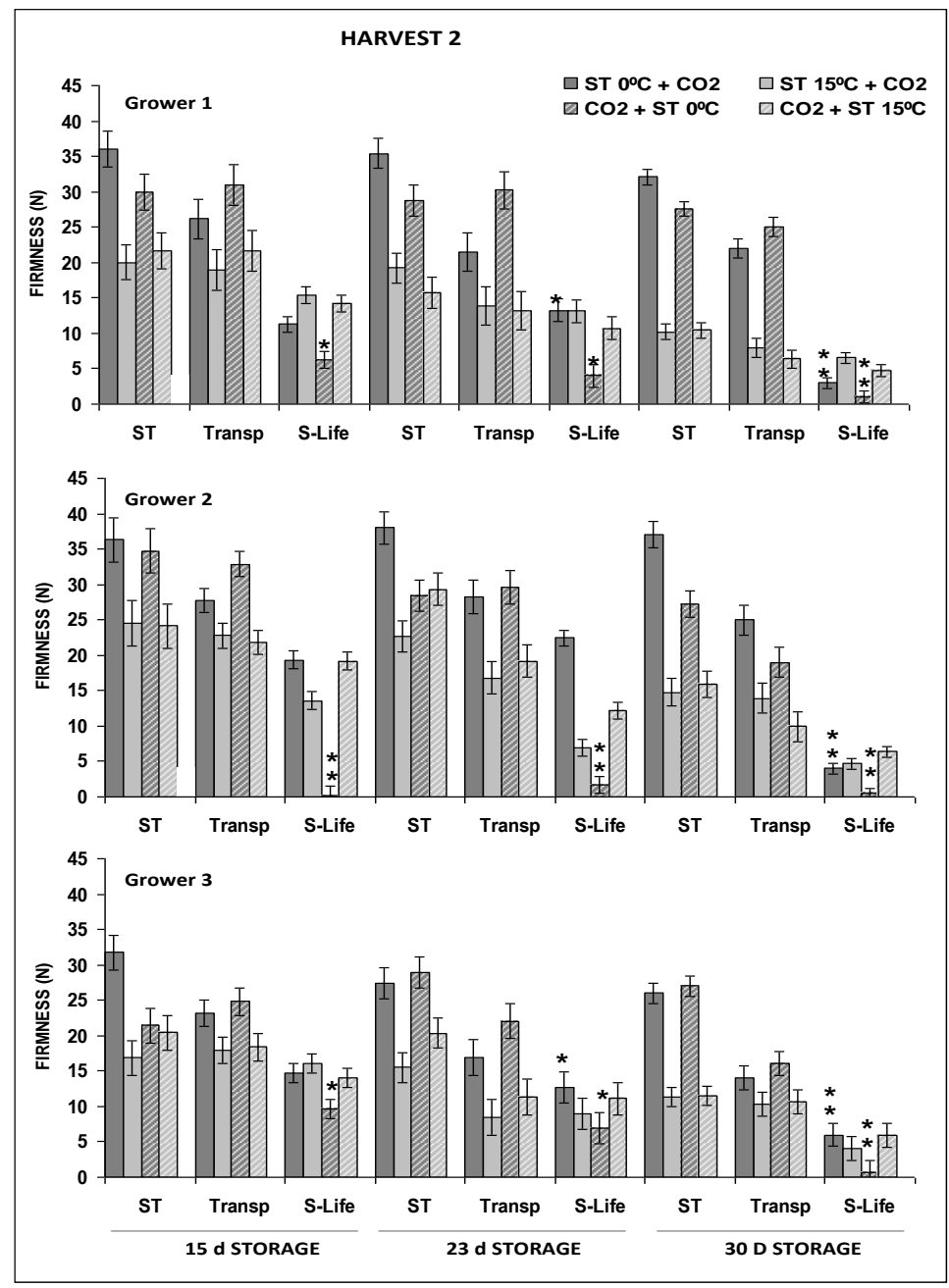

Fig. 2. Effect of the storage temperature $\left(0{ }^{\circ} \mathrm{C}\right.$ and $\left.15{ }^{\circ} \mathrm{C}\right)$ and the moment of application of the $\mathrm{CO}_{2}$-deastrignency treatment (before or after the storage period) on the firmness of 'Rojo Brillante' persimmon harvested at the end of October and stored for up to 1 month. (ST: storage; Transp: transportation period of 4 days at $5{ }^{\circ} \mathrm{C}$; S-Life: shelf-life period of 5 days at $20^{\circ} \mathrm{C}$ ). One asterisk indicates "slight-medium flesh gelling" and two asterisk indicate "severe flesh gelling". 


\section{Conclusions}

The maturity stage of the fruit is a decisive factor for storage of organic persimmon. Fruit harvested with firmness values lower than $30 \mathrm{~N}$ should be not stored, since the decline of firmness after harvest compromises their quality. However, fruit with values of firmness between 30 and $45 \mathrm{~N}$ could be stored for up to 2-3 weeks.

The quality of the fruit during storage was also determined by the storage temperature and the moment of applying the $\mathrm{CO}_{2}$ deastringency treatment. Fruit stored at $0{ }^{\circ} \mathrm{C}$ before being submitted to the deastringency treatment maintained an acceptable quality for two weeks. However, when the deastringency treatment was applied before the coolstorage, the manifestation of chilling injury symptoms was hastened; the drastic softening and flesh gelling symptoms resulted on unacceptable quality fruit.

Fruit stored at $15{ }^{\circ} \mathrm{C}$ after removing of astringency showed commercial quality for three weeks. However, the $\mathrm{CO}_{2}$ treatment was not completely effective when applied after the storage at $15{ }^{\circ} \mathrm{C}$, which resulted on fruit with certain level of astringency and therefore non marketable.

\section{Acknowledgements}

This study has been founded by the Consellería de Educación, Investigación, Cultura y Deporte de la Comunidad Valenciana (proyect GV/2016/183).

\section{References}

Arnal, L., \& Del Río, M. A. (2003). Removing Astringency by Carbon Dioxide and Nitrogen-Enriched Atmospheres in Persimmon Fruit cv. "Rojo brillante". Journal of Food Science. 68(4), 1516-1518. https://doi.org/10.1111/j.1365-2621.2003.tb09676.x 
Arnal, L., \& Del Río, M. (2004). Effect of cold storage and removal astringency on quality of persimmon fruit (Diospyros kaki, L.) cv. Rojo Brillante. Food Science and Technology International. 10(3), 179-185. https://doi.org/10.1177/1082013204044824

Besada, C., Arnal, L., \& Salvador, A. (2008). Improving storability of persimmon cv. Rojo Brillante by combined use of preharvest and postharvest treatments. Postharvest Biology and Technology. 50,169-175. https://doi.org/10.1016/j.postharvbio.2008.05.013

Besada, C., Novillo, P., Navarro, P., \& Salvador, A. (2014). Effect of a low oxygen atmosphere combined with 1-MCP pretreatment on preserving the quality of 'Rojo Brillante' and 'Triumph' persimmon during cold storage. Scientia Horticulturae. 179, 51-58. https://doi.org/10.1016/j.scienta.2014.09.015

Collins, R., \& Tisdell, J. (1995). The influence of storage time and temperature on chilling injury in Fuyu and Suruga persimmon (Diospyros kaki L.) grown in subtropical Australia. Postharvest Biology and Technology. 6(1), 149157. https://doi.org/10.1016/0925-5214(94)00046-U

Crisosto, C. H. (2004). Persimmon Postharvest Quality Maintenance Guidelines. Retreived from:

http//postharvest.ucdavis.edu/Produce/ProduceFacts/Fruit/persimmon.shtml.

Jiménez-Cuesta, M., Cuquerella, J., \& Martínez-Jávega, J.M. (1981). Determination of a color index for citrus fruit degreening. Proceedings of the International Society of Citriculture. 2, 750-753.

MacRae, E. (1987). Development of chilling injury in New Zealand grown 'Fuyu'persimmon during storage. New Zealand Journal of Experimental Agriculture. 15(3), 333-344. https://doi.org/10.1080/03015521.1987.10425579

Novillo, P., Salvador, A., Navarro, P., \& Besada, C. (2015). Involvement of the Redox System in Chilling Injury and Its Alleviation by 1- 
Methylcyclopropene in 'Rojo Brillante' Persimmon. Hortscience 50(4),570-576. https://doi.org/10.21273/HORTSCI.50.4.570

Salvador, A., Arnal, L., Besada, C., Larrea, V., Hernando, I., \& Pérez-Munuera, I. (2008). Reduced effectiveness of the treatment for removing astringency in persimmon fruit when stored at $15^{\circ} \mathrm{C}$ : Physiological and microstructural study. Postharvest Biology and Technology. 49, 340-34. https://doi.org/10.1016/j.postharvbio.2008.01.015

Salvador, A., Arnal, L., Carot, J.M., Carvalho, C., \& Jabaloyes, J.M. (2006). Influence of different factors on firmness and color evolution during the storage of persimmon cv. 'Rojo Brillante'. Journal of Food Science. 71, 169-175.

Taira, S. (1995). Astringency in persimmon. In: Linskens, H.F. and J.F. Jackson (eds.). Modern methods of plant analysis. Fruit analysis. Springer, Berlin. pp. 297-311.

Testoni, A. (2002). Post-harvest and processing of persimmon fruit. In: Bellini, E., Giordani, E., eds. Options Méditerranéennes: Série A. Séminaires Méditerranéens. 51, CIHEAM-IAMZ, Zaragoza, Spain, pp. 53-66. http://om.ciheam.org/article.php?IDPDF=2600062 
III.3. EVALUATION OF POSTHARVEST BEHAVIOR OF CULTIVARS INTRODUCED FROM OTHER COUNTRIES UNDER MEDITERRANEAN CONDITIONS

CHAPTERS VI and VII 



\title{
CHAPTER VI
}

\section{Harvest time and postharvest behavior of six Japanese non-astringent persimmon cultivars grown under Mediterranean conditions}

\author{
Ayoub Fathi Najafabadi, Cristina Besada, Rebeca Gil, \\ Alejandra Salvador
}

Postharvest Department. Instituto Valenciano de Investigaciones Agrarias.

Ctra. Moncada Naquera Km. 4.5. 46113 Moncada, Valencia, Spain

Reference: HortScience, 2020, 55 (11), 1766-1771.

https://doi.org/10.21273/HORTSCI15181-20 



\begin{abstract}
Persimmon cultivation has significantly grown in the Mediterranean Region in recent years. The production concentrates mainly in three astringent cultivars: Kaki Tipo in Italy, Triumph in Israel and Rojo Brillante in Spain. Therefore, the varietal range expansion is one of the current challenges for persimmon producers in this area. Moreover, the introduction of non-astringent persimmon cultivars is particularly interesting because they can be commercialized immediately after harvest without applying deastringency treatment before commercialization. This study evaluated the harvest period and the postharvest response of six Japanese non-astringent cultivars (Kanshu, Shinshu, Soshu, Suruga, Youhou, Izu). During two seasons, fruit from each cultivar were harvested at two maturity stages. Fruit quality (external color, firmness and total soluble solids) were evaluated after harvest and after different commercial scenarios (domestic market- 7 days at $20{ }^{\circ} \mathrm{C}$, market to UE- 5 days at $5{ }^{\circ} \mathrm{C}$ plus 5 days at $20{ }^{\circ} \mathrm{C}$ and market to countries with coldquarantine treatment requirements- 21 days at $0{ }^{\circ} \mathrm{C}$ plus 5 days at $20{ }^{\circ} \mathrm{C}$ ). Cultivars Kanshu, Shinshu, Soshu and Izu were identified as early cultivars, and Soshu was the earliest one, which reached commercial maturity at the beginning of September. These four cultivars showed good quality after simulating commercialization on domestic and EU markets. Cultivars Suruga and Youhou overlapped the current harvest window, but their low chilling injury sensitiveness is highlighted. So they are of special interest to be coldstored at the end of the season to be commercialized in overseas markets.
\end{abstract}

Keywords: Izu, Kanshu, Shinshu, Soshu, Suruga, Youhou 


\section{Introduction}

In Europe, persimmon cultivation is located mainly in the Mediterranean Region where it was traditionally a minor crop, but has significantly expanded in the last few decades. In this area, persimmon production takes place chiefly in three countries: Italy, Israel and Spain. Nowadays in the Mediterranean Region, persimmon production is based mostly on monovarietal cultivation. In Italy, almost $90 \%$ of persimmon production is based on 'Kaki Tipo'. In Israel, 'Triumph', under the 'Sharon' trademark, is the main cultivar and consists of 95\% of total persimmon production (Yesiloglu et al., 2018). In the last 20 years, Spain's persimmon cultivation grown the most and more quickly in this area, mainly due to the increased production of cultivar Rojo Brillante in the Valencian Community of Spain (Perucho, 2018).

Centralized production of a single cultivar is one of the main problems that the persimmon industry must face as this implies a major commercial limitation given harvesting period concentration and the high phytosanitary risk. Therefore, one common objective for growers, marketers and researchers is to introduce cultivars that allow the varietal range of persimmon to extend with certain success guarantees. It is noteworthy that the main cultivars presently grown in this area are astringent at harvest, which implies that fruit have to be submitted to postharvest treatments to remove astringency before commercialization. Accordingly, the introduction of non-astringent cultivars is of special interest to simplify postharvest fruit handling.

In this context, a persimmon breeding program has been developed in Spain at the Instituto Valenciano de Investigaciones Agrarias (IVIA) since 2002 (Martinez-Calvo et al., 2018). Besides plant breeding to obtain new cultivars, a germplasm bank with cultivars from different geographical areas has been created as part of this program to evaluate their response under our Mediterranean agroclimatic conditions. It has been reported that the climate differences between persimmon-growing regions can lead to a wider variation in persimmon fruit maturity and quality at harvest (Soqanloo, 2015; Zanamwe, 2018).

Among the persimmon cultivars under study, a group of Japanese cultivars brought from the National Institute of Fruit Tree Science of Japan (NIFTS) 
stands out for being non-astringent cultivars and are, therefore, of much potential interest to extend the varietal range in this persimmon-growing area.

One of the main factors of agronomic behavior to condition commercial interest in the different cultivars is harvest time. The introduction of early and late cultivars can prolong the production period with subsequent profits for industry. Currently, the harvesting period of the main persimmon cultivars grown in the Mediterranean Region is mid-October to December. Therefore, the cultivars that reach commercial maturity earlier or later in the season must be considered of special interest for introduction purposes.

The selection of new cultivars involves having to evaluate their postharvest behavior to guarantee quality preservation and to respond to the high quality standards that consumers demand (Kader \& Yahia, 2011). It is worth highlighting that persimmon with a soft texture is normally eaten in Asian countries, but is consumed when flesh is still firm in European countries. Thus fruit firmness is one of the main quality parameters that needs to be preserved during its postharvest life. This may be a challenge as most persimmon cultivars are sensitive to chilling injuries when stored at low temperature. Flesh softening and flesh gelling are the main symptoms of this disorder (Besada \& Salvador, 2018; Tessmer et al., 2019). Although a minimum firmness value is not established by current persimmon quality standards, according to previous studies, $20 \mathrm{~N}$ is considered the limiting firmness value from which fruit would not be acceptable for commercialization (Besada et al., 2010).

In order to evaluate the postharvest behavior of fruit, it is important to consider the different commercialization scenarios. The persimmon fruit produced in Mediterranean countries are usually commercialized in three different ways: a) sending fruit directly to domestic market at ambient temperature; b) transporting fruit to European Union (EU) countries in refrigerated trucks at $5{ }^{\circ} \mathrm{C} ; \mathrm{C}$ ) shipping fruit to overseas countries, like the USA, for which quarantine treatment is needed and fruit must be keep at low temperature $\left(0-1{ }^{\circ} \mathrm{C}\right)$ for at least 21 days. The third scenario is that in which chilling injury and fruit firmness reduction are more likely to happen.

In this context, the objective of this study was to determine the harvest period and postharvest behavior under the Mediterranean agroclimatic conditions of 
six non-astringent Japanese persimmon cultivars belonging to the IVIA germplasm bank to select which ones are suitable for extending this region's varietal range.

\section{Materials and Methods}

\subsection{Plant material, fruit harvest and storage}

The cultivars that this study evaluated were Kanshu, Shinshu, Sohsu, Suruga, Youhou and Izu. They were all released by the National Institute of Fruit Tree Science (NIFTS-Japan) (Table 1) and were introduced into the IVIA Germplasm bank in 2014 thanks to an agreement reached between the IVIA and NIFTS. They were cultivated following the habitual agronomic practices in an experimental germplasm bank orchard located in L'Alcúdia, Valencia, Spain (39 $\left.11^{\prime} 18.7^{\prime \prime} \mathrm{N} 0^{\circ} 32^{\prime} 06.2^{\prime \prime} \mathrm{W}\right)$ at an altitude of $42 \mathrm{~m}$ above sea level. This area has a Mediterranean climate characterized by 3-5 months of summer drought (June-September). The distribution of rainfall is among autumn, winter, and spring with the highest rainfall during the autumn.

Table 1. Genetic origin and year of release of the studied persimmon cultivars

\begin{tabular}{cccc}
\hline $\begin{array}{c}\text { Cultivar } \\
\text { name }\end{array}$ & Genetic origin & $\begin{array}{c}\text { Year of } \\
\text { release }\end{array}$ & References \\
\hline Kanshu & $\begin{array}{c}\text { Shinshu } \times \text { 18-4(Fuyu } \times \text { Okitsu-16) (Oku- } \\
\text { gosho } \times \text { Hana-gosho) }\end{array}$ & 2002 & $\begin{array}{c}\text { Tetsumura et la, 2008; } \\
\text { Yamada et al, 2006 }\end{array}$ \\
\hline Shinshu & $\begin{array}{c}\text { Okitsu-20 (Fukuro-Gosho } \times \text { Hana-Gosho) } \\
\text { Okitsu-1 (Oku-gosho } \times \text { Oku-gosho) }\end{array}$ & 1991 & $\begin{array}{c}\text { Tetsumura et al, 2008; } \\
\text { Yamada and Sato, 2003 }\end{array}$ \\
\hline Soshu & Izu $\times 109-27($ Okitsu-2 $\times$ Okitsu-17) & 2000 & Tetsumura et al., 2008 \\
\hline Suruga & Hana-gosho $\times$ Oku-gosho & 1959 & Tetsumura et la, 2008; \\
\hline Youhou & Fuyu $\times$ Jiro & 1990 & $\begin{array}{c}\text { Testsumura et al., 2008; } \\
\text { Yamada and Sato, 2003 }\end{array}$ \\
\hline Izu & Fuyu $\times$ Okitsu-1 & 1970 & Yamada and Sato, 2003 \\
\hline
\end{tabular}


The study was carried out during two seasons (2017-18) with fruit from at least three trees of each cultivar. The average annual rainfall was between $450-550$ $\mathrm{mm}$, and the mean annual temperature was $18{ }^{\circ} \mathrm{C}$ in both studied years. Two harvests took place during the first season. Changes in skin coloration have been reported to be linked with the main physicochemical changes during persimmon maturation (Salvador et al., 2007; Veberic et al., 2010), and skin color is habitually used as the maturity index for harvesting. In this study, the first harvest of each cultivar was carried out when fruit displayed a homogeneous orange to orange-red color, with no visible green background, according to Besada \& Salvador (2018). The second harvest took place some 15-20 days later. Depending on the results obtained for the first season per cultivar, one or two harvests were organized during the second season to corroborate the previous results or to acquire new information.

On each harvest date, and depending on fruit availability, 80-100 fruits were collected and immediately transported to IVIA's Postharvest Laboratory Technology Center. Fruit were carefully evaluated to avoid selecting those with external damage. They were separated into four lots of 20 fruits. One lot was used to characterize maturity stage and fruit quality at harvest. The fruit from the other lots were placed in plastic trays and submitted to the conditions related to the following commercialization scenarios: 1 ) fruit stored for 7 days at $20{ }^{\circ} \mathrm{C}$ to simulate commercialization on domestic market (D); 2) fruit stored for 5 days at $5{ }^{\circ} \mathrm{C}$, plus 5 days at $20^{\circ} \mathrm{C}$, to simulate transport to EU countries, plus shelf-life (EU); 3) fruit stored for 21 days at $0{ }^{\circ} \mathrm{C}$, plus 5 days at $20^{\circ} \mathrm{C}$, to simulate shipping to countries with quarantine treatment, e.g. the USA, plus shelf-life (USA). Quarantine treatment requirements for USA exportation are 14 days at $1.1{ }^{\circ} \mathrm{C}$ or lower temperature. Fruit was kept for 21 days at the storage chamber at $0{ }^{\circ} \mathrm{C}$ in order to include in this commercial scenario the habitual delay before shipment which usually lasts 5-6 days.

It is important to clarify that, due to the limited number of available fruit, only those scenarios during some harvests that gave the most consistent results were tested. 


\subsection{Fruit assessments}

Color, firmness and total soluble solids (TSS) were determined after each harvest and after simulated commercialization scenarios. External skin color was determined by a Minolta colorimeter (Model CR-300, Ramsey, NY). Hunter parameters $(L, a, b)$ were measured and the results were expressed as a color index: $\mathrm{Cl}=1000 \mathrm{a} / \mathrm{Lb}$, according to Salvador et al. (2007). Fruit firmness was established in a Texturometer Instron Universal Machine model 4301 (Instron Corp., Canton, MA, USA) using an $8 \mathrm{~mm}$-diameter plunger and breaking the flesh in each fruit on $180^{\circ}$ sides after removing peel. To determine TSS, fruit were peeled and placed in an electric juice extractor (model 753, Moulinex, Spain) and the obtained juice was filtered through cheesecloth. The TSS juice was measured over three replicates by a digital refractometer (model PR-1, Atago, Japan) and expressed as \% (FW).

\subsection{Statistical analysis}

Data were subjected to an analysis of variance based on two factors (harvest time $\times$ commercialization scenarios) during each season. The mean values of the evaluated parameters were compared by the least significant difference test $(P<0.05)$ using the StatgraphicsPlus 5.1 software application (Manugistics Inc., Rockville, MD, USA).

\section{Results and discussion}

'Kanshu'.

'Kanshu' persimmon is flattened to oblong with irregular rounded to square cross section (Fig. 1A). In Japan, the average fruit weight is around 230-244 g (Yakushiji \& Nakatsuka, 2007; Yamada et al., 2006), higher than in Spain where it is close to $120-170 \mathrm{~g}$ (average data recorded for the last three years of production in germplasm bank). In Japan, this fruit cultivar is harvested late in October with TSS close to $18 \%$ with medium flesh firmness and excellent eating quality (Yakushiji and Nakatsuka, 2007). 


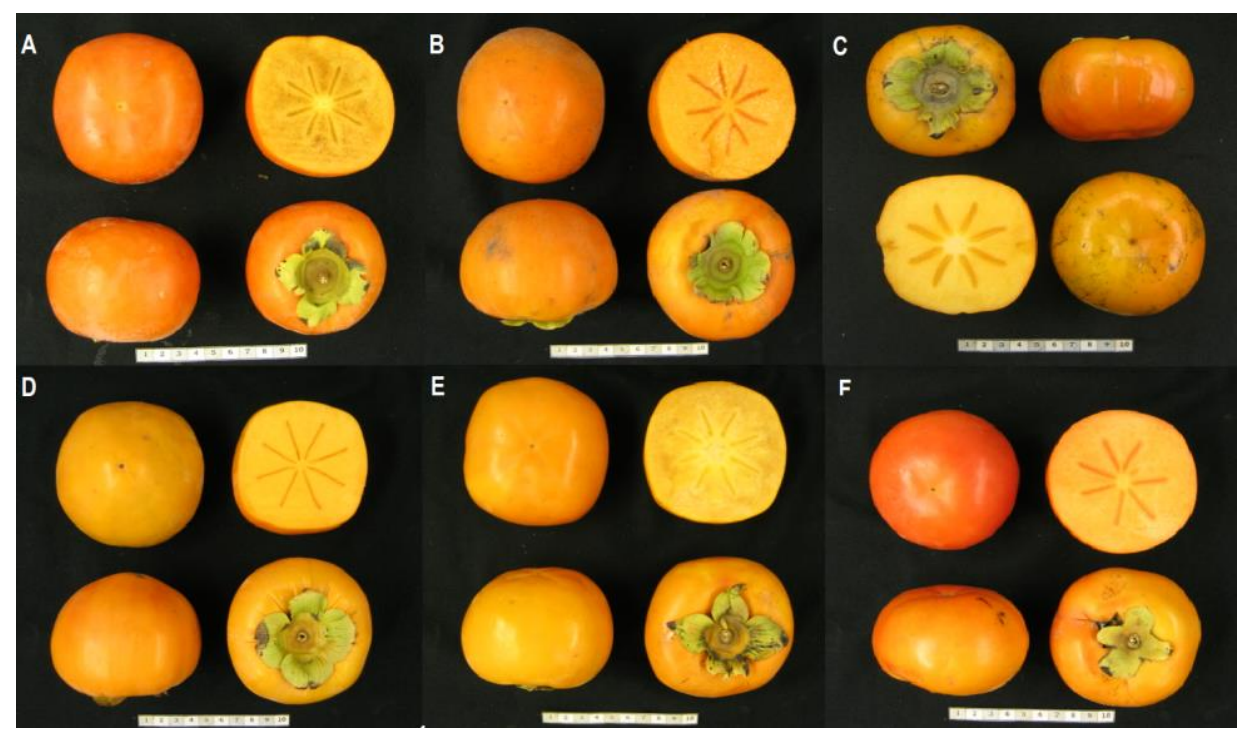

Fig. 1. Persimmon fruit of 'Kanshu' (A), 'Shinshu' (B), 'Soshu' (C), 'Suruga' (D), 'Youhou' (E) and 'Izu' (F). Photo courtesy of Plant Production Department (IVIA).

In our study, the first harvest was carried out on 18 Sept. (S1-H1) when fruit showed an orange coloration ( $\mathrm{Cl}$ close to +9 ), high flesh firmness around $72 \mathrm{~N}$ and a TSS value of $16.9 \%$ (Table 2). After 2 weeks on trees, external color and firmness had not significantly changed, but TSS had increased to above $18.2 \%$ $(\mathrm{S} 1-\mathrm{H} 2)$. During the second season, two harvests were organized later in the season to evaluate if harvest period could be prolonged. Fruit were harvested on 28 Oct. (S2-H1) and 8 Nov. (S2-H2), when they were bright red in color, with $\mathrm{Cl}$ close to +28 and +32 , and had a high TSS content from 20 to $21 \%$ during the first and the second harvest, respectively. Nevertheless, on both dates, fruit had low firmness values close to $19 \mathrm{~N}$. 
Table 2. Color index (Cl), firmness and total soluble solids (TSS) determined in persimmon cv. Kanshu on different harvest dates $(\mathrm{H})$ during two consecutive seasons (S1-S2) and after stimulating distinct commercialization scenarios: D (Domestic market commercialization- 7 days at $20^{\circ} \mathrm{C}$ ), EU (transport to European Union- 5 days at $5{ }^{\circ} \mathrm{C}$ plus 5 days at $20^{\circ} \mathrm{C}$ ) and USA (shipping to overseas markets- 21 days at $0{ }^{\circ} \mathrm{C}$ plus 5 days at $\left.20^{\circ} \mathrm{C}\right)$.

${ }^{x}$ For each evaluated parameter and season (S) different letters among scenarios (Harvest, D, EU and USA) indicate statistical differences $\mathrm{P}<0.05$ (LSD test).

$\mathrm{ND}=$ not determined

\begin{tabular}{|c|c|c|c|c|c|}
\hline Season & Harvest & Analysis & $\begin{array}{c}\mathrm{Cl} \\
(1000 \mathrm{a} / \mathrm{Lb})\end{array}$ & $\begin{array}{c}\text { Firmness } \\
(\mathrm{N})\end{array}$ & $\begin{array}{c}\text { TSS } \\
(\% \mathrm{FW})\end{array}$ \\
\hline \multirow{8}{*}{ (S1) } & & Harvest & $8.7 a^{x}$ & $72.6 \mathrm{~d}$ & $16.9 a$ \\
\hline & (H1) & $\mathrm{D}$ & $11.7 a b$ & $65.8 \mathrm{~cd}$ & $21.4 \mathrm{c}$ \\
\hline & Sept 18 & EU & $10.5 a b$ & $54.4 \mathrm{~b}$ & $19.9 \mathrm{bc}$ \\
\hline & & USA & $17.8 \mathrm{c}$ & $6.5 a$ & $20.1 b c$ \\
\hline & & Harvest & $9.0 \mathrm{a}$ & $64.9 \mathrm{~cd}$ & $18.2 a$ \\
\hline & $(\mathrm{H} 2)$ & $\mathrm{D}$ & 11.9ab & $62.1 \mathrm{c}$ & $18.4 a b$ \\
\hline & Oct 01 & EU & $13.5 b$ & $54.1 b$ & $17.6 a$ \\
\hline & & USA & $20.3 c$ & $5.0 a$ & $20.9 c$ \\
\hline \multirow{8}{*}{ (S2) } & & Harvest & $27.9 a$ & $19.6 b$ & $19.6 a$ \\
\hline & (H1) & D & $31.7 a b$ & $17.0 \mathrm{~b}$ & $19.9 a$ \\
\hline & Oct 28 & EU & ND & ND & ND \\
\hline & & USA & $33.0 \mathrm{bc}$ & $4.5 a$ & $21.3 a b$ \\
\hline & & Harvest & $31.7 a b$ & $19.1 b$ & $20.7 a$ \\
\hline & $(\mathrm{H} 2)$ & D & $35.4 \mathrm{bc}$ & $15.0 \mathrm{~b}$ & $23.7 \mathrm{~b}$ \\
\hline & Nov 08 & $\mathrm{EU}$ & ND & ND & ND \\
\hline & & USA & $35.3 c$ & $5.0 \mathrm{a}$ & 21.6ab \\
\hline
\end{tabular}

According to the data obtained from the different harvests, 'Kanshu' reached commercial maturity earlier and had a slightly lower TSS content under Mediterranean than under Japanese conditions. Its harvest period was earlier 
than the cultivars currently cultivated on the Mediterranean coast. Fruit maturation evolution was relatively slow in the second half of September, but significantly advanced in October.

Regarding postharvest behavior, in Japan it is reported that fruit are suitable for consumption for 15 days at ambient temperature (Yamada et al., 2006). During the first season in the present study, fruit firmness decreased, which was greater with longer storage duration. Although the firmness values remained high after domestic and EU commercialization scenarios, they drastically dropped to non-commercial values, close to 5-6 N, after the USA conditions simulation, which indicates this cultivar's high susceptibility to manifest chilling injury at low temperature. In parallel to firmness loss, both color and TSS increased. In the second season, when fruit were harvested with firmness close to $20 \mathrm{~N}$, the fruit softening during the postharvest period was a limiting factor even for commercialization on domestic market. Sensitivity to low temperatures was corroborated during this season.

So the optimum harvest time for this cultivar would be from mid-September to early October, when fruit external color is appealing, its firmness is high and TSS contents come close to $17-18 \%$. If fruit are harvested later, firmness loss would be a major limitation for posterior commercialization. Moreover, the drastic drop in firmness of this fruit cultivar after being exposed to $0{ }^{\circ} \mathrm{C}$ indicates that this cultivar is susceptible to manifest chilling injury symptoms.

\section{'Shinshu'.}

'Shinshu' persimmon is oval with irregular rounded cross section (Fig. 1B). The fruit weight is around $240-250 \mathrm{~g}$ (data from Japan) (Yakushiji \& Nakatsuka, 2007; Yamada \& Sato, 2003). Similar fruit weight has been recorded here in Spain (data recorded for the last three years of production in germplasm bank). In Japan, 'Shinshu' persimmons are harvested in late October with TSS content at around $17 \%$, and with soft flesh firmness and high eating quality (Yakushiji \& Nakatsuka, 2007; Yamada \& Sato, 2003). 
Under Mediterranean conditions, the fruits of this cultivar displayed external yellowish-orange tones ( $\mathrm{Cl}$ close to +7$)$ at the beginning of October, when TSS content was $18.5 \%$ and fruit had high firmness values close to $65 \mathrm{~N}$ (S1-H1) (Table 3). Only 2 weeks later on 15 Oct. (S1-H2), fruit ripening ha rapidly advanced, with color increase accompanied by marked firmness loss. For this reason, fruit were collected during the second season on 11 Oct. when it was in an intermediate maturity stage between both stages evaluated during the previous season. Therefore, fruit maturation under Mediterranean conditions happened earlier and the TSS value was relatively higher than in Japan. Our results also revealed that the maturation of these cultivars happened 2 weeks earlier than that of the cultivars currently cultivated in Spain and Italy.

In Japan, the average shelf-life of this cultivar lasts about 8 days at ambient temperature (Yamada \& Sato, 2003). Producing fruit in greenhouses is recommended due to excessive softening when exposed to rain or wetness (Yamada et al, 2012). Although significant softening occurred after 7 days at 20 ${ }^{\circ} \mathrm{C}$ (domestic market) in the present study, fruit quality was suitable for commercialization irrespectively of harvest date. Under the EU conditions, only the fruit harvested with high firmness $(\mathrm{S} 1-\mathrm{H} 1)$ still had commercial values. However, all fruit displayed drastic softening after the USA commercialization. This finding indicates that this cultivar is very sensitive to chilling injury when exposed to $0{ }^{\circ} \mathrm{C}$, which was observed for the two evaluated seasons.

According to our results, this cultivar should be harvested at the beginning of October to ensure that fruit firmness at harvest is high enough to be commercialized on domestic and European markets. This fruit should not be sent to overseas markets because of its high susceptibility to manifest chilling injury. 
Table 3. Color index (Cl), firmness and total soluble solids (TSS) determined in persimmon $\mathrm{cv}$. Shinshu on different harvest dates $(H)$ during two consecutive seasons (S1-S2) and after stimulating distinct commercialization scenarios: D (Domestic market commercialization- 7 days at $20^{\circ} \mathrm{C}$ ), EU (transport to European Union- 5 days at $5{ }^{\circ} \mathrm{C}$ plus 5 days at $20^{\circ} \mathrm{C}$ ) and USA (shipping to overseas markets- 21 days at $0{ }^{\circ} \mathrm{C}$ plus 5 days at $\left.20^{\circ} \mathrm{C}\right)$.

${ }^{\mathrm{x}}$ For each evaluated parameter and season (S) different letters among scenarios (Harvest, D, EU and USA) indicate statistical differences $P<0.05$ (LSD test).

$N D=$ not determined

\begin{tabular}{|c|c|c|c|c|c|}
\hline Season & Harvest & Analysis & $\begin{array}{c}\mathrm{Cl} \\
(1000 \mathrm{a} / \mathrm{Lb})\end{array}$ & $\begin{array}{c}\text { Firmness } \\
\text { (N) }\end{array}$ & $\begin{array}{c}\text { TSS } \\
(\% \mathrm{FW})\end{array}$ \\
\hline \multirow{8}{*}{ (S1) } & \multirow{4}{*}{$\begin{array}{l}\text { (H1) } \\
\text { Oct. } 01\end{array}$} & Harvest & $7.2 \mathrm{a}^{\mathrm{x}}$ & $64.8 f$ & $18.5 a$ \\
\hline & & D & $9.7 b$ & $39.5 \mathrm{e}$ & $18.2 \mathrm{a}$ \\
\hline & & EU & $10.2 b$ & $31.8 \mathrm{~d}$ & $18.5 a$ \\
\hline & & USA & $11.6 \mathrm{~b}$ & $4.4 a$ & $19.4 b$ \\
\hline & \multirow{4}{*}{$\begin{array}{l}(\mathrm{H} 2) \\
\text { Oct. } 15\end{array}$} & Harvest & $11.9 \mathrm{~b}$ & 36.6de & $19.6 \mathrm{bc}$ \\
\hline & & D & $17.1 \mathrm{c}$ & $25.0 \mathrm{c}$ & $20.2 \mathrm{~cd}$ \\
\hline & & EU & $18.1 \mathrm{c}$ & $11.3 b$ & $20.7 \mathrm{~cd}$ \\
\hline & & USA & $22.5 d$ & $0.8 a$ & $23.4 d$ \\
\hline \multirow{4}{*}{ (S2) } & \multirow{4}{*}{$\begin{array}{l}(\mathrm{H} 1) \\
\text { Oct. } 11\end{array}$} & Harvest & $12.6 a$ & $42.3 \mathrm{c}$ & $20.4 a$ \\
\hline & & D & $18.6 \mathrm{~b}$ & $24.7 b$ & $23.1 b$ \\
\hline & & EU & ND & ND & ND \\
\hline & & USA & $21.8 \mathrm{~b}$ & $0.0 a$ & $23.4 b$ \\
\hline
\end{tabular}

\section{'Soshu'.}

'Shoshu' persimmon is flattened with irregular rounded cross section (Fig. 1C). The average fruit weight is around $250 \mathrm{~g}$ (data from Japan) (Yakushiji \& Nakatsuka, 2007; Yamada et al., 2012). In Spain the data recorded so far indicates a fruit weight between 170 to $250 \mathrm{~g}$ (average data recorded for the last three years of production in germplasm bank). In Japan, 'Soshu' fruit are harvested from late September to early October, with TSS close to $15 \%$, 
medium flesh firmness and moderate sweetness (Yakushiji \& Nakatsuka, 2007; Yamada et al., 2012).

In this study, 'Soshu' already displayed adequate external coloration, $\mathrm{Cl}$ close to +10 , a TSS content of around $15 \%$ and firmness values of $48.4 \mathrm{~N}$ on $5 \mathrm{Sept}$. (S1-H1) (Table 4). After 2 weeks (S1-H2), fruit external color had increased (Cl close to +18 ) and firmness values had lowered to around $42 \mathrm{~N}$. No significant changes in TSS were observed between these two harvests. During the second season, the fruit harvested on 12 Sept had $\mathrm{Cl}$ close to +12 , a firmness value of $39.3 \mathrm{~N}$ and TSS content of $16 \%$, which allowed us to corroborate harvest time.

In Japan, a semi-short shelf-life is reported for this cultivar (Yamada et al., 2012). Accordingly, fruit softening was considerable during our postharvest period, even after simulating domestic market commercialization. The fruit harvested with the most firmness (48 $\mathrm{N}$ at $\mathrm{S} 1-\mathrm{H} 1)$ presented values exceeding $22 \mathrm{~N}$ after 7 days at $20^{\circ} \mathrm{C}(\mathrm{N})$. However, when it was harvested with firmness values close to $42 \mathrm{~N}$ (S1-H2), firmness values were $13 \mathrm{~N}$, which would be below the acceptability limit. Although commercialization to EU was simulated only during the first harvest (S1-H1), major firmness loss was detected. During both seasons, fruit underwent drastic softening with values below $10 \mathrm{~N}$ after the USA commercialization, which indicates this cultivar's high sensitivity to manifest this disorder at low temperature.

According to our results, the optimal harvest time for this cultivar would be the beginning of September which is, therefore, earlier than in Japan, and also much earlier than the cultivars currently cultivated in the Mediterranean Region. The shelf-life of this fruit would shorten if it were harvested later because this cultivar is prone to postharvest firmness loss. 
Table 4. Color index (Cl), firmness and total soluble solids (TSS) determined in persimmon cv. Soshu on different harvest dates $(\mathrm{H})$ during two consecutive seasons (S1-S2) and after stimulating distinct commercialization scenarios: D (Domestic market commercialization- 7 days at $20^{\circ} \mathrm{C}$ ), EU (transport to European Union- 5 days at $5{ }^{\circ} \mathrm{C}$ plus 5 days at $20^{\circ} \mathrm{C}$ ) and USA (shipping to overseas markets- 21 days at $0{ }^{\circ} \mathrm{C}$ plus 5 days at $\left.20^{\circ} \mathrm{C}\right)$.

${ }^{x}$ For each evaluated parameter and season (S) different letters among scenarios (Harvest, D, EU and USA) indicate statistical differences $P<0.05$ (LSD test).

$N D=$ not determined

\begin{tabular}{|c|c|c|c|c|c|}
\hline Season & Harvest & Analysis & $\begin{array}{c}\mathrm{Cl} \\
(1000 \mathrm{a} / \mathrm{Lb})\end{array}$ & $\begin{array}{c}\text { Firmness } \\
\text { (N) }\end{array}$ & $\begin{array}{c}\text { TSS } \\
\text { (\%FW) }\end{array}$ \\
\hline \multirow{8}{*}{ (S1) } & \multirow{4}{*}{$\begin{array}{c}\text { (H1) } \\
\text { Sept.05 }\end{array}$} & Harvest & $10.1 a^{x}$ & $48.4 d$ & $14.9 a b$ \\
\hline & & D & $11.1 \mathrm{a}$ & $22.5 \mathrm{c}$ & $14.3 a$ \\
\hline & & EU & $21.5 \mathrm{~b}$ & $15.8 \mathrm{bc}$ & $15.4 \mathrm{~b}$ \\
\hline & & USA & $18.5 b$ & $8.0 a$ & $16.1 \mathrm{~b}$ \\
\hline & \multirow{4}{*}{$\begin{array}{c}\text { (H2) } \\
\text { Sept } 20\end{array}$} & Harvest & $18.2 b$ & $42.5 \mathrm{~d}$ & $15.6 \mathrm{~b}$ \\
\hline & & D & $29.8 \mathrm{c}$ & $13.0 \mathrm{~b}$ & $17.7 \mathrm{c}$ \\
\hline & & EU & ND & ND & ND \\
\hline & & USA & $37.1 \mathrm{~d}$ & $0.0 a$ & $15.4 \mathrm{~b}$ \\
\hline \multirow{4}{*}{ (S2) } & \multirow{4}{*}{$\begin{array}{c}(\mathrm{H} 1) \\
\text { Sept. } 12\end{array}$} & Harvest & $12.4 a$ & $39.3 c$ & $16.0 \mathrm{~b}$ \\
\hline & & D & $18.9 b$ & $13.5 \mathrm{~b}$ & $13.9 \mathrm{a}$ \\
\hline & & EU & ND & ND & ND \\
\hline & & USA & $23.0 \mathrm{~b}$ & $0.0 \mathrm{a}$ & 15.5ab \\
\hline
\end{tabular}

\section{'Suruga'.}

Suruga persimmon is flattened with square cross section (Fig. 1D). The average fruit weight is close to $182 \mathrm{~g}$ (data from Australia and from the germplasm bank of Spain) (Collins et al., 1995). In Japan, 'Suruga' is a late cultivar. Fruit are harvested from early to mid-November, but can be left on trees without softening until late November (Yamada \& Sato, 2003). In California, harvest 
time goes from November to early December, and TSS is over 20\% (Miller \& Crocker, 1994).

In our study, the first harvest was carried out on 8 Nov. when external coloration was bright red ( $\mathrm{Cl}$ close to 20), the TSS content went above $16 \%$ and firmness values were high, around $59 \mathrm{~N}$ (Table 5). Twenty days later (S1-H2), no significant changes in external coloration and firmness were observed, but TSS significantly increased to values close to $18 \%$. During the second season (S2), harvest date and fruit characteristics were confirmed.

After simulating different commercialization scenarios, the firmness values lowered. Nevertheless, the values after the domestic commercialization, and even after the EU simulation, were still high. It was noteworthy that fruit maintained their commercial firmness values after the USA market simulation, which reveals low sensitivity to manifest disorders associated with low temperatures. Collins \& Tisdell (1995) reported that 'Suruga' fruits cultivated in Australia did not suffer chilling injury at $0{ }^{\circ} \mathrm{C}$ for up to 56 days, plus a 7-day shelf-life. Fruit characteristics and postharvest behavior, mainly low chilling injury susceptibility, were corroborated during the second season.

In the Mediterranean Region, the 'Suruga' harvest could be carried out from the beginning to the end of November to achieve adequate firmness at harvest and after different commercial scenarios. Thus the harvesting period in this area coincides with the harvest time in Japan. This cultivar is highlighted by showing low susceptibility to chilling injury and preserving firmness after the USA commercialization scenario, as reported in other studies. 
Table 5. Color index (Cl), firmness and total soluble solids (TSS) determined in persimmon cv. Suruga on different harvest dates $(H)$ during two consecutive seasons (S1-S2) and after stimulating distinct commercialization scenarios: D (Domestic market commercialization- 7 days at $20^{\circ} \mathrm{C}$ ), EU (transport to European Union- 5 days at $5{ }^{\circ} \mathrm{C}$ plus 5 days at $20^{\circ} \mathrm{C}$ ) and USA (shipping to overseas markets- 21 days at $0{ }^{\circ} \mathrm{C}$ plus 5 days at $\left.20^{\circ} \mathrm{C}\right)$.

${ }^{\mathrm{x}}$ For each evaluated parameter and season (S) different letters among scenarios (Harvest, D, EU and USA) indicate statistical differences $P<0.05$ (LSD test).

$N D=$ not determined

\begin{tabular}{|c|c|c|c|c|c|}
\hline Season & Harvest & Analysis & $\begin{array}{c}\mathrm{Cl} \\
(1000 \mathrm{a} / \mathrm{Lb})\end{array}$ & $\begin{array}{c}\text { Firmness } \\
\text { (N) }\end{array}$ & $\begin{array}{c}\text { TSS } \\
\text { (\%FW) }\end{array}$ \\
\hline \multirow{8}{*}{ (S1) } & & Harvest & $19.6 a^{x}$ & $58.9 c$ & $16.2 a$ \\
\hline & (H1) & D & $22.1 \mathrm{ab}$ & $41.9 \mathrm{~b}$ & $16.7 a b$ \\
\hline & Nov. 08 & EU & $31.9 \mathrm{c}$ & $24.1 a$ & 16.9ab \\
\hline & & USA & $32.6 \mathrm{~b}$ & $20.1 a$ & $17.4 \mathrm{~b}$ \\
\hline & & Harvest & $21.2 \mathrm{ab}$ & $47.2 \mathrm{bc}$ & $17.8 \mathrm{~b}$ \\
\hline & $(\mathrm{H} 2)$ & D & ND & ND & ND \\
\hline & Nov. 28 & EU & $30.9 c$ & $43.6 \mathrm{bc}$ & $17.3 a b$ \\
\hline & & USA & $34.8 \mathrm{c}$ & $21.8 a$ & 17.5ab \\
\hline \multirow{4}{*}{ (S2) } & & Harvest & $12.2 \mathrm{a}$ & $53.8 \mathrm{~b}$ & $14.9 a$ \\
\hline & & D & ND & ND & ND \\
\hline & 1000.00 & EU & ND & ND & ND \\
\hline & & USA & $15.9 b$ & $34.6 a$ & $17.3 \mathrm{~b}$ \\
\hline
\end{tabular}

\section{'Youhou'.}

'Youhou' persimmon is flattened with irregular rounded cross section (Fig. 1E). In Japan, the average fruit weight is around 240-280 g (Yamada \& Sato, 2003; Yamada et al., 2012). Data recorded so far indicates that fruit in Spain is smaller, with weight values around 130-200 g (average data recorded for the last three years of production in germplasm bank). In Japan, the fruit of this cultivar are harvested at the beginning of November with TSS content of 15- 
17\%, firm flesh firmness and excellent taste (Yamada \& Sato, 2003; Yamane et al., 1991).

Under our Mediterranean conditions, 'Youhou' fruits were harvested on 16 Oct. (S1-H1) with external coloration close to +9 , a very high firmness value $(83.2 \mathrm{~N}$ ) and a TSS content near 17\% (Table 6). Similar TSS values were shown after 15 days, although color had significantly increased ( $\mathrm{Cl}=17.3$ ) and firmness had slightly decreased $(72.2 \mathrm{~N})$. For the first season, the firmness values at harvest were very high. Thus, during the second season, fruit were harvested later on $8 \mathrm{Nov}$. and $27 \mathrm{Nov}$. to investigate the maturity process on trees. At both harvests fruit had high firmness values above $48 \mathrm{~N}$, and their external color values lay between +18 and +25 . Therefore, the maturation process on the trees of this cultivar was slow, which led to a long harvest period lasting from mid- October to the end of November.

Regarding postharvest behavior, this cultivar in Japan has been reported to be stored for about 2 weeks at ambient temperature (Yamane et al., 1991). As trees had very few fruits during our first season, a decision was made to perform only the USA marketing simulation. Although the postharvest firmness values lowered, fruit maintained commercial values close to $23 \mathrm{~N}$ and $30 \mathrm{~N}$ during the first and the second harvest, respectively. So these results revealed low chilling susceptibility, which was corroborated during the second season. In China, Li et al. (2018) observed that the chilling injury symptoms of 'Youhou' fruits stored for 21 days at $1{ }^{\circ} \mathrm{C}$, plus 5 days at $25{ }^{\circ} \mathrm{C}$, were only very slight, which agrees with our results. Fruit also responded well after the domestic commercialization and UE simulations herein studied during the second season.

'Youhou' had a long harvest period, from mid-October to late November, and fruits maintained commercial firmness after simulating the different marketing scenarios. They presented little sensitivity to low temperature. 
Table 6. Color index $(\mathrm{Cl})$, firmness and total soluble solids (TSS) determined in persimmon $\mathrm{cv}$. Youhou on different harvest dates $(\mathrm{H})$ during two consecutive seasons (S1-S2) and after stimulating distinct commercialization scenarios: D (Domestic market commercialization- 7 days at $20^{\circ} \mathrm{C}$ ), EU (transport to European Union- 5 days at $5{ }^{\circ} \mathrm{C}$ plus 5 days at $20^{\circ} \mathrm{C}$ ) and USA (shipping to overseas markets- 21 days at $0{ }^{\circ} \mathrm{C}$ plus 5 days at $\left.20^{\circ} \mathrm{C}\right)$.

${ }^{x}$ For each evaluated parameter and season (S) different letters among scenarios (Harvest, D, EU and USA) indicate statistical differences $P<0.05$ (LSD test).

$\mathrm{ND}=$ not determined

\begin{tabular}{|c|c|c|c|c|c|}
\hline Season & Harvest & Analysis & $\begin{array}{c}\mathrm{Cl} \\
(1000 \mathrm{a} / \mathrm{Lb})\end{array}$ & $\begin{array}{c}\text { Firmness } \\
\text { (N) }\end{array}$ & $\begin{array}{c}\text { TSS } \\
(\% \mathrm{FW})\end{array}$ \\
\hline \multirow{8}{*}{ S1 } & & Harvest & $9.3 a^{x}$ & $83.2 d$ & $16.9 a$ \\
\hline & $(\mathrm{H} 1)$ & D & ND & ND & ND \\
\hline & Oct. 16 & EU & ND & ND & ND \\
\hline & & USA & $19.2 \mathrm{~b}$ & $23.0 \mathrm{a}$ & $17.2 \mathrm{a}$ \\
\hline & & Harvest & $17.3 b$ & $72.2 \mathrm{c}$ & $17.4 a$ \\
\hline & $(\mathrm{H} 2)$ & D & ND & ND & ND \\
\hline & Oct. 31 & EU & ND & ND & ND \\
\hline & & USA & $27.5 \mathrm{c}$ & $30.5 b$ & $18.7 a$ \\
\hline \multirow{8}{*}{ S2 } & & Harvest & $18.5 a$ & $55.1 \mathrm{c}$ & $16.3 a$ \\
\hline & $(\mathrm{H} 1)$ & D & 18.9ab & $52.1 \mathrm{c}$ & $16.5 a b$ \\
\hline & Nov. 08 & EU & $21.9 b c$ & $49.2 \mathrm{c}$ & $17.6 \mathrm{~b}$ \\
\hline & & USA & $29.3 \mathrm{c}$ & $37.7 b$ & $17.6 \mathrm{~b}$ \\
\hline & & Harvest & $25.5 \mathrm{c}$ & $48.5 \mathrm{c}$ & $16.9 a b$ \\
\hline & $(\mathrm{H} 2)$ & D & ND & ND & ND \\
\hline & Nov. 27 & EU & $33.3 d$ & $30.1 \mathrm{a}$ & $17.5 b$ \\
\hline & & USA & $35.2 d$ & $20.1 a$ & 17.2ab \\
\hline
\end{tabular}


'Izu'.

'Izu' persimmon is flattened to oblong with irregular rounded to square cross section (Fig. 1F). The average fruit weight is around 230-240 g in Japan (Sato \& Yamada, 2003; Yamada et al., 2012). Data recorded so far in Spain indicates a similar fruit weight around 180-200 g (average data recorded for the last three years of production in germplasm bank). In California and Japan, the fruit of this cultivar are harvested from late September to mid-October and, therefore, this cultivar is known as an early cultivar in both areas (Miller \& Crocker, 1994; Yamada et al., 2012). In Japan, harvested fruit have a TSS content of 15\%, medium flesh firmness and a delicious taste.

Under our Mediterranean conditions, 'Izu' fruit reached the homogenous orange color $(\mathrm{Cl}=+12.1)$ on 8 Oct., when the firmness value was $39.2 \mathrm{~N}$ and TSS content came close to $17.5 \%(\mathrm{~S} 1-\mathrm{H} 1)$ (Table 7). The second harvest was carried out 15 days later (S1-H2). At this time, fruit showed more intense coloration $(\mathrm{Cl}=+19.1)$, but no significant changes in firmness and TTS content values were detected.

In Japan, a short shelf-life has been reported for this cultivar (Yamada, 2005). In this study, the postharvest analysis revealed that during domestic commercialization, fruit still had firmness values close to those at harvest. Softening became more marked after the EU simulation, which could compromise fruit quality when it reaches consumers. The firmness value drastically lowered after the USA simulation, which indicates that this cultivar is very sensitive to chilling injury.

During the second season, in which fruit was harvested on 16 Oct., the previous results about characteristic at harvest and postharvest behavior were corroborated.

According to the results, the harvest period for 'Izu' under Mediterranean conditions would be from early to late October, which coincides with the harvest dates reported in California and Japan. Although fruit firmness was not very high at harvest, its commercial values remained after simulating the 
domestic and EU commercializations. However, it was sensitive to low temperatures.

Table 7. Color index (Cl), firmness and total soluble solids (TSS) determined in persimmon cv. Izu on different harvest dates $(\mathrm{H})$ during two consecutive seasons (S1S2) and after stimulating distinct commercialization scenarios: D (Domestic market commercialization- 7 days at $20^{\circ} \mathrm{C}$ ), EU (transport to European Union- 5 days at $5{ }^{\circ} \mathrm{C}$ plus 5 days at $20^{\circ} \mathrm{C}$ ) and USA (shipping to overseas markets- 21 days at $0{ }^{\circ} \mathrm{C}$ plus 5 days at $\left.20^{\circ} \mathrm{C}\right)$.

${ }^{\mathrm{x}}$ For each evaluated parameter and season (S) different letters among scenarios (Harvest, D, EU and USA) indicate statistical differences $P<0.05$ (LSD test).

$\mathrm{ND}=$ not determined

\begin{tabular}{|c|c|c|c|c|c|}
\hline Season & Harvest & Analysis & $\begin{array}{c}\mathrm{Cl} \\
(1000 \mathrm{a} / \mathrm{Lb})\end{array}$ & $\begin{array}{c}\text { Firmness } \\
\text { (N) }\end{array}$ & $\begin{array}{c}\text { TSS } \\
(\% \mathrm{FW})\end{array}$ \\
\hline \multirow{8}{*}{ (S1) } & & Harvest & $12.1 a^{x}$ & $39.2 d$ & $17.5 a$ \\
\hline & (H1) & D & ND & ND & ND \\
\hline & Oct. 08 & EU & $13.5 a$ & $22.4 \mathrm{~b}$ & $17.6 a$ \\
\hline & & USA & $15.8 \mathrm{~b}$ & $2.7 a$ & $18.1 \mathrm{~b}$ \\
\hline & & Harvest & $19.1 \mathrm{c}$ & $35.5 c d$ & $17.2 a$ \\
\hline & $(\mathrm{H} 2)$ & D & $21.2 \mathrm{c}$ & $30.6 c$ & $17.3 a b$ \\
\hline & Oct. 31 & EU & $19.1 \mathrm{c}$ & $20.3 b$ & $17.4 a$ \\
\hline & & USA & $28.1 d$ & Oa & $18.2 \mathrm{~b}$ \\
\hline \multirow{4}{*}{ (S2) } & & Harvest & $11.10 a$ & $37.8 \mathrm{c}$ & $17.35 a$ \\
\hline & (H1) & D & 12.9ab & $35.9 \mathrm{c}$ & $17.0 a$ \\
\hline & Oct. 16 & EU & $15.1 b$ & $27.1 b$ & 17.0a \\
\hline & & USA & $21.2 \mathrm{c}$ & 9.1a & $18.3 b$ \\
\hline
\end{tabular}




\section{Conclusions}

In the present work, the harvest window of the six studied cultivars grown under Mediterranean conditions differed for most of them from that reported for Japanese conditions. This was true of 'Kanshu' and 'Shinshu', which are harvested late in October in Japan, while their harvest time was earlier when grown in Spain, from mid-September to early October for 'Kanshu', and in the first half of September for 'Shinshu'. Likewise, 'Soshu' is harvested from the end of September in Japan, but its optimum harvest time was early September in the Mediterranean Region. However, cultivars Suruga, Youhou and Izu had the same harvest period in both Spain and Japan. It is noteworthy that the optimal harvest time herein established fell in line with the criterion that fruit displayed homogeneous color and high firmness at harvest and firmness was maintained after the main commercial scenarios because it is one of the most important quality parameters. This differs in other production areas, where persimmon is consumed as soft fruit.

Nowadays the harvest window of persimmon in the Mediterranean Region goes from mid- October to December. In this study, cultivars Kanshu, Shinshu, Izu and Soshu showed earlier commercial maturity, and Soshu stood out as the earliest cultivar because it can be harvested at the beginning of September. However, it is worth mentioning that all these cultivars were susceptible to manifest chilling injury when stored at low temperature. Therefore, fruit should not be destined to long-distance markets. In the particular case of 'Soshu', its postharvest fast softening compromises its fruit quality when it arrives in the EU. Hence this fruit cultivar should be destined only to domestic market.

Cultivars Suruga and Youhou overlapped the harvesting window of the cultivars already cultivated in countries like Spain, Italy or Israel, but both can be highlighted for their low susceptibility to manifest chilling injury when stored at low temperature. Nowadays, the persimmons cultivars grown in the Mediterranean Region are normally submitted to 1-MPC treatment before being transported to EU and overseas markets to avoid excessive fruit softening. Thus 'Suruga' and 'Youhou' could be good alternatives for the 
industry to be sent to overseas markets with quarantine treatments and no previous postharvest treatment.

The information herein provided is also useful for persimmon breeders. The cultivars that offer early maturation and those not sensitive to chilling injury could be used as plant material for future crossings in breeding programs.

\section{Acknowledgements}

This work has been funded by the Instituto Nacional de Investigación y Tecnología Agraria y Alimentaria (INIA) and Fondo Europeo de Desarrollo Regional (FEDER) through Project RTA2017-00045-C02-01. Ayoub Fathi Najafabadi thanks the INIA for grant FPI-INIA \#43 (CPD2015-0151). The authors thank Cooperativa Agrícola Ntra Sra de L'Oreto for its technical support and for making the plots and fruit used in this study available. The authors wish to thank Plant Production Department (Instituto Valenciano de Investigaciones Agrarias) for providing the fruit weight data and the photographs of the different varieties.

\section{References}

Besada, C., \& Salvador, A. (2018. Postharvest Biology and Technology of Persimmon. In: Mir S., Shah M., and M. Mir (eds.). Postharvest Biology and Technology of Temperate Fruits. Springer, Cham. https://doi.org/10.1007/978-3-319-76843-4_16

Besada, C., Jackman, R.C., Olsson, S., \& Woolf, A.B. (2010). Response of 'Fuyu' persimmons to ethylene exposure before and during storage. Postharvest Biology and Technology. 57(2), 124-131. https://doi.org/10.1016/j.postharvbio.2010.03.002

Collins, R.J., George, A.P., \& Nissen, R.J. (1995). Extending the marketing season of non-astringent persimmons grown in sub-tropical Australia. 
Acta Horticulturae.

409,

75-84.

https://doi.org/10.17660/ActaHortic.1995.409.7

Collins, R.J., \& Tisdell, J.S. (1995) The influence of storage time and temperature on chilling injury in Fuyu and Suruga persimmon (Diospyros kaki L.) grown in subtropical Australia. Postharvest Biology and Technology. 6(1-2), 149-157. https://doi.org/10.1016/09255214(94)00046-U

Kader, A., \& Yahia, E. (2011). Postharvest biology of tropical and subtropical fruits. Postharvest Biology and Technology of Tropical and Subtropical Fruits. 79-111. https://doi.org/10.1533/9780857093622.79

Li, J., Han, Y., Hu, M., Jin, M., \& Rao, J. (2018). Oxalic acid and 1methylcyclopropene alleviate chilling injury of 'Youhou' sweet persimmon during cold storage. Postharvest Biology and Technology. 137, 134-141. https://doi.org/10.1016/j.postharvbio.2017.11.021

Martínez-Calvo, J., Climent, J., Naval, M.M., \& Badenes, M.L. (2018). The I.V.I.A. germplasm collection of persimmon (Diospyros kaki Thunb.). Acta Horticulturae. 1195 ,

55-60. https://doi.org/10.17660/ActaHortic.2018.1195.9

Miller, E.P. \& Crocker, T.E. (1994). Oriental persimmons in Florida. Florida cooperative extension service, institute of food and agricultural sciences, university of Florida. This document is SP 101, 1-16.

Perucho, R. (2018). Evolution of production of the 'Rojo Brillante' cultivar in Spain and its impact on markets. Acta Horticulturae. 1195, 1-8. https://doi.org/10.17660/ActaHortic.2018.1195.1

Salvador, A., Arnal, L., Besada, C., Larrea, V., Quiles, A., \& Perez-Munuera, I. (2007). Physiological and structural changes during ripening and deastringency treatment of persimmon fruit cv. 'Rojo Brillante'. Postharvest Biology and Technology. 46(2), 181-188. https://doi.org/10.1016/j.postharvbio.2007.05.003 
Sato, A., \& Yamada, M. (2003). Leading persimmon cultivars for commercial production and breeding targets in Japan. Acta Horticulturae. 601, 25-30. https://doi.org/10.17660/ActaHortic.2003.601.2

Soqanloo, S.S. (2015). Effect of different regional climates on persimmon quality. Journal of Civil Engineering and Environmental Sciences. 1(1), 008012. DOI: $10.17352 / 2455-488 X .000003$

Tessmer, M.A., Appezzato-da-Glória, B., \& Kluge, R.A. (2019). Evaluation of storage temperatures to astringency 'Giombo' persimmon: Storage at 1 ${ }^{\circ} \mathrm{C}$ combined with 1-MCP is recommended to alleviate chilling injury. Scientia Horticulturae. 257, 108675 . https://doi.org/10.1016/j.scienta.2019.108675

Tetsumura, T., Giordani, E., \& Tao, R. (2008). Persimmon (kaki). In: C. Kole and T.C. Hall (eds.). Compendium of Transgenic Crop Plants: Transgenic Tropical and Subtropical Fruits and Nuts. Blackwell Publishing, Oxford. pp. 235-257. https://doi.org/10.1002/9781405181099.k0510

Veberic, R., Jurhar, J., Mikulic-Petkovsek, M., Stampar, F., \& Schmitzer, V. (2010). Comparative study of primary and secondary metabolites in 11 cultivars of persimmon fruit (Diospyros kaki L.). Food Chemistry. 119, 477483. https://doi.org/10.1016/j.foodchem.2009.06.044

Yakushiji, H., \& Nakatsuka, A. (2007). Recent persimmon research in Japan. Japanese Journal of Plant Science. 1, 42-62.

Yamada, M., \& Sato, A. (2003). Persimmon cultivars released in the 1990 s by the national institute of fruit tree science in Japan. Acta Horticulturae. 601, 19-23. https://doi.org/10.17660/ActaHortic.2003.601.1

Yamada, M. (2005). Persimmon genetic resources and breeding in japan. Acta Horticulturae. 685 , 55-64. https://doi.org/10.17660/ActaHortic.2005.685.5

Yamada, M., Sato, A., Yamane, H., Yoshinaga, K., Hirakawa, N., Iwanami, H., Ozawa, T., Kakutani, M., Mitani, N., Yoshioka, M., \& Nakajima, I. (2006). 
New Japanese persimmon cultivar 'Kanshu'. Bulletin of the National Institute of Fruit Tree Science. 5, 95-106

Yamada, M., Giordani, E., \& Yonemori, K. (2012). Persimmon. In: Badenes M., and D. Byrne. (eds.). Fruit Breeding. Handbook of Plant Breeding, vol 8. Springer, Boston, MA. https://doi.org/10.1007/978-1-4419-0763-9_17

Yamane, H., Kurihara, A., Nagata, K., Yamada, M., Kishi, T., Yoshinaga, K., Matsumoto, R., Kanato, K., Sumi, T., Hirabayashi, T., Ozawa, T., Hirose, K., Yamamoto, M., \& Kakutani, M. (1991). New Japanese persimmon cultivar 'Youhou'. Bulletin of the Fruit Tree Research Station. 20, 49-61

Yesiloglu, T., Cimen, B., Incesu, M., \& Yilmaz, B. (2018). Genetic diversity and breeding of persimmon. Breeding and health benefits of fruit and nut crops. Soneji, J., \& Nageswara-Rao, M. IntechOpen. 21-46. DOI: 10.5772/intechopen.74977

Zanamwe, P. (2018). Effects of production area and harvest maturity on postharvest quality of South African 'Triumph' persimmon fruit (diospyros kaki). African Journal of Horticultural Science. 13, 31-42. 


\title{
CHAPTER VII
}

\section{Caracterización de variedades de caqui no astringentes del banco de germoplasma del IVIA}

\author{
Ayoub Fathi Najafabadi, Cristina Besada, Rebeca Gil, \\ Alejandra Salvador
}

Centro de Tecnología Postcosecha del Instituto Valenciano de Investigaciones Agrarias (IVIA), Moncada, Valencia, España

Reference: Agrícola vergel, 2020, N428, 216-220 



\section{Resumen}

La introducción de variedades de caqui es uno de los principales retos en toda el área de producción mediterránea, ya que en la actualidad este cultivo se centraliza en una única variedad, con la limitación en la comercialización y los riesgos fitosanitarios que ello conlleva. La introducción de variedades procedentes de otros países exige de estudios para conocer su comportamiento agronómico bajo nuestras condiciones de cultivo, pero además es necesario conocer su comportamiento postcosecha, ya que de ello va a depender su interés comercial. En este trabajo se ha estudiado el comportamiento postcosecha de 14 variedades no astringentes del banco de germoplasma del IVIA ('Soshu', 'Kanshu', 'Shinshu', 'Izu', 'Youhou', 'Koda Gosho', 'Cal Fuyu','Ichikikei Jiro', 'Suruga', 'Ban Gosho', 'Jiro', 'Fuyu', 'Isahaya' y ' $O$ ' gosho'). Para cada una de las variedades se ha establecido el periodo de recolección, evaluándose la calidad físico-química de la fruta (color, firmeza y solidos solubles totales) y se ha determinado su aptitud frente a los siguientes escenarios de comercialización: mercado Nacional ( 7 días a $20^{\circ} \mathrm{C}$ ), exportación a países de la UE ( 5 días a $5{ }^{\circ} \mathrm{C}+5$ días a $20^{\circ} \mathrm{C}$ ) y envíos a países de ultramar como EEUU bajo condiciones cuarentenarias ( 21 días a $0{ }^{\circ} \mathrm{C}+5$ días a $20^{\circ} \mathrm{C}$ ).

Keywords: recolección, postcosecha, color, firmeza, sólidos solubles totales, daño por frío, 1-MCP 


\section{Introducción}

El cultivo del caqui se ha convertido en los últimos 15 años en uno de los cultivos más rentables de la Comunidad Valenciana. Su producción está centralizada en la variedad 'Rojo Brillante', una de las más apreciadas a nivel mundial por la calidad de sus frutos. Sin embargo, el corto periodo de campaña que presenta este cultivar supone una importante limitación comercial. Esto, unido al riesgo fitosanitario que implica un cultivo monovarietal, hace que uno de los principales retos del Sector sea la introducción de nuevas variedades que permitan ampliar tanto la gama varietal como el período de comercialización, para poder así responder a la demanda creciente del mercado.

Con este objetivo el Instituto Valenciano de Investigaciones Agrarias (IVIA), en colaboración con la Cooperativa Agrícola Nuestra Señora de L'Oreto Coop. V. (CANSO), viene desarrollando desde el año 2004 un Programa de Mejora del Caqui con el objetivo de obtener nuevas variedades mediante mejora genética convencional y biotecnológica. Además, en el marco de este Programa se ha creado un Banco de Germoplasma con variedades de caqui procedentes de diferentes áreas geográficas para evaluar su respuesta en nuestras condiciones agroclimáticas mediterráneas.

Entre las variedades introducidas en el Banco de Germoplasma se encuentran un grupo de variedades no astringentes, de especial interés ya que, a diferencia de las astringentes, entre las que se encuentra el 'Rojo Brillante', pueden ser comercializadas directamente tras la cosecha sin las complicaciones de manejo y el coste económico que conlleva la aplicación del tratamiento de desastringencia.

El comportamiento agronómico de estas variedades bajo nuestras condiciones mediterráneas está siendo evaluado. Sin embargo, es necesario también conocer el momento óptimo de recolección, así como su comportamiento postcosecha, con el fin de conocer su potencial interés comercial en el contexto actual del mercado de caqui.

Los frutos de caqui tras la cosecha pueden ser sometidos a diferentes condiciones dependiendo del destino final de los mismos. Actualmente los 
escenarios de comercialización más comunes son el mercado Nacional, la exportación a la Unión Europea y la exportación a países de ultramar, entre los que destaca EEUU.

La utilización de bajas temperaturas para el mantenimiento de la calidad es común durante el transporte y comercialización de la fruta y llega a ser un requisito para su exportación a determinados países que exigen tratamientos cuarentenarios en frío. Sin embargo, un factor que puede limitar la comercialización de los frutos de caqui bajo condiciones de bajas temperaturas es la susceptibilidad que presentan a manifestar alteraciones conocidas como 'daños por frio'. Aunque depende de la variedad, los daños por frío en caqui se asocian en la mayoría de los casos con alteraciones en la firmeza de la pulpa. El principal síntoma de daño por frío es un ablandamiento drástico de la pulpa, aunque también se han reportado otros síntomas como gelificación de la pulpa o 'flesh gelling' y oscurecimiento interno, así como transparencia de la piel (MacRae, 1987; Collins \& Tisdell, 1995; Woolf et al., 1997; Arnal \& Del Río, 2004).

En la actualidad, para poder mantener el caqui a bajas temperaturas se debe aplicar un tratamiento con 1-metilciclopropeno (1-MCP) (Smartfresh ${ }^{\mathrm{TM}}$ ) previamente al almacenamiento frigorífico, ya que se ha demostrado que retrasa la aparición de los síntomas de daños por frío en diferentes variedades, entre las que se encuentran 'Rojo Brillante', 'Triumph' y 'Fuyu' (Tsviling et al., 2003; Salvador et al., 2004; Krammes et al., 2006; Besada et al., 2008).

La introducción de nuevas variedades requiere por tanto del estudio de su respuesta bajo condiciones de almacenamiento frigorífico, ya que de ello dependerá en gran medida su potencial de comercialización y conservación.

El objetivo del presente trabajo fue el estudio del periodo de cosecha y comportamiento postcosecha de 14 variedades no astringentes bajo condiciones mediterráneas de cultivo. 


\section{Procedimiento Experimental}

\subsection{Material vegetal}

Las 14 variedades caracterizadas fueron 'Soshu', 'Kanshu', 'Shinshu', 'Izu', 'Youhou', 'Koda Gosho', 'Cal Fuyu','Ichikikei Jiro', 'Suruga', 'Ban Gosho', 'Jiro', 'Fuyu', 'Isahaya' y 'O' gosho' (Fig. 1).

Las variedades evaluadas se encuentran en parcelas experimentales situadas en la provincia de Valencia. Dos de estas parcelas pertenecen al IVIA, una de

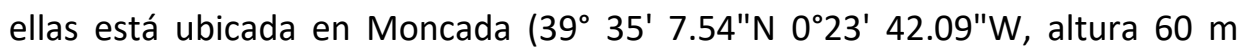
sobre el nivel del mar) y la otra en Llutxent ( $38^{\circ} 56^{\prime} 20^{\prime \prime} \mathrm{N} 0^{\circ} 21^{\prime} 37^{\prime \prime} \mathrm{W}$, altura $288 \mathrm{~m}$ sobre el nivel del mar). Se evaluaron también variedades localizadas en la parcela experimental perteneciente a la Cooperativa Agrícola Nuestra Señora de L'Oreto Coop. V. (CANSO) ubicada en L'Alcúdia $\left(39^{\circ} 11^{\prime} 18.7^{\prime \prime} \mathrm{N}\right.$ $0^{\circ} 32^{\prime} 06.2^{\prime \prime} \mathrm{W}$, altura $42 \mathrm{~m}$ sobre el nivel del mar) y en una parcela experimental propiedad de Anecoop S. Coop. situada en Museros (39 $34^{\prime} 37^{\prime \prime} \mathrm{N} 0^{\circ} 21^{\prime} 53^{\prime \prime} \mathrm{W}$, altura $33 \mathrm{~m}$ sobre el nivel del mar) (Tabla 1 ).

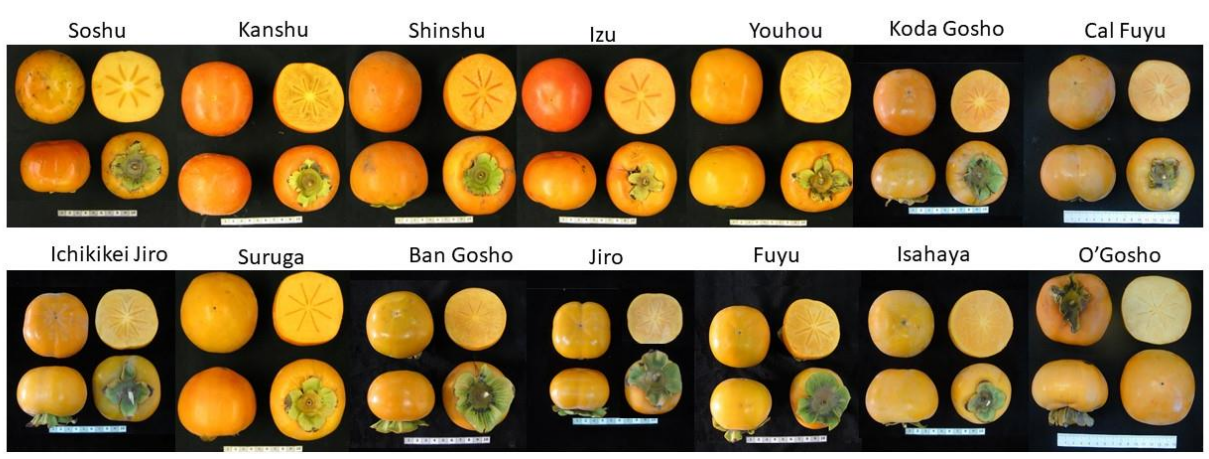

Fig. 1. Variedades de caqui evaluadas. Fuente de las imágenes: Centro de Citricultura y Protección Vegetal del IVIA. 
Table 1. Origen genético y parcelas experimentales en las que se ubican las variedades estudiadas.

\begin{tabular}{lll}
\hline Variedad & \multicolumn{1}{c}{ Origen Genético } & \multicolumn{1}{c}{ Parcela experimental } \\
\hline Soshu & Izu x 109-27 (Okitsu-2 x Okitsu-17) & L'Alcudia \\
Kanshu & Shinshu x 18-4(Fuyu x Okitsu-16) (Oku-Gosho x Hana-gosho) & L'Alcudia \\
Shinshu & $\begin{array}{l}\text { Okitsu-20 (Fukuro-gosho x Hana-gosho) x Okitsu-1 (Oku- } \\
\text { gosho x Oku-gosho) }\end{array}$ & L'Alcudia \\
Izu & Fuyu x A4(OkugoshoxOku-gosho) & L'Alcudia/Museros \\
Youhou & Fuyu x Jiro & L'Alcudia \\
KodaGosho & No se dispone de información & Museros / Llutxent \\
Cal Fuyu & No es clara su identidad genética & Moncada /Museros \\
Ichikikei & Mutación de Jiro & L'Alcudia \\
Jiro & Hana-gosho $\times$ Oku-gosho & L'Alcudia \\
Suruga & No se dispone de información & Moncada/ L'Alcudia \\
Ban Gosho & Plántula & Moncada/ L'Alcudia/ \\
Jiro & Plántula & Museros \\
Fuyu & Mutación de Fuyu & Moncada/Museros \\
Isahaya & No se dispone de información & Moncada / L'Alcudia \\
\hline
\end{tabular}

\subsection{Caracterización fisiológica de la madurez}

Con el objetivo de determinar el periodo óptimo de recolección de las diferentes variedades se llevó a cabo la caracterización fisiológica de la madurez del fruto. Para ello, y teniendo en cuenta que el color externo del fruto es el índice de recolección no destructivo utilizado para el caqui, se realizó un seguimiento del color del fruto en campo mediante evaluaciones periódicas entre mitad de agosto a final de diciembre. Se determinó así el periodo de viraje de color (de verde a naranja) y también el periodo en el que la coloración externa del fruto pasa a ser naranja homogénea, ya que a partir de entonces es cuando la fruta puede ser comercializada (Besada \& Salvador, 2018). 
Con el objetivo de determinar la calidad interna del fruto, en el estado en que éste alcanzó una coloración externa homogénea y en dos estados más avanzados, se recolectó fruta y se evaluaron los parámetros relacionados con la calidad físico-química.

\subsection{Evaluación del comportamiento postcosecha}

En el momento en que el fruto alcanzó una coloración naranja homogénea y en dos estados de madurez más avanzados (transcurridos aproximadamente 10 y 20 días) se recolectó la fruta de las diferentes variedades y se formaron lotes de 15-20 frutos para ser sometidos a los principales escenarios de comercialización: 1) mercado Nacional ( 7 días a $20^{\circ} \mathrm{C}$ ), 2) Exportación a la UE (5 días a $5{ }^{\circ} \mathrm{C}+5$ días a $20{ }^{\circ} \mathrm{C}$ ), 3) Exportación a EEUU bajo condiciones de cuarentena ( 21 días a $0{ }^{\circ} \mathrm{C}+5$ días a $20^{\circ} \mathrm{C}$ ). En aquellas variedades que presenten sensibilidad a las bajas temperaturas se evaluó su respuesta al tratamiento con 1-MCP.

En el momento de recolección y periódicamente durante el transcurso de la simulación de la comercialización se evaluaron los principales parámetros relacionados con la calidad físico-química (color, firmeza y sólidos solubles totales (SST), así como la incidencia de alteraciones internas o externas. Todas las determinaciones se realizaron según la metodología descrita por Salvador et al. (2007) y Novillo et al. (2014).

\section{Resultados}

En la Figura 2 se muestra el periodo de recolección establecido bajo nuestras condiciones mediterráneas y en la Tabla 2 los rangos de índice de color externo, SST y firmeza, que presenta la fruta en el momento de cosecha. Además, se muestran los valores de firmeza que muestra la fruta tras ser sometida a los diferentes escenarios de comercialización, ya que es el parámetro que compromete en mayor medida la calidad del caqui durante este periodo. 
Centrándonos en el momento de recolección, la variedad más temprana fue 'Soshu' que a principios de septiembre ya presentó una coloración homogénea anaranjada, con IC de 10 , un nivel de SST cercanos a $15^{\circ}$ Brix y una firmeza de pulpa elevada de $50 \mathrm{~N}$. Tras dos semanas, a mitad de septiembre, la coloración se incrementó hasta alcanzar tonalidades rojizas (IC de 20), mientras que la firmeza descendió hasta valores de $40 \mathrm{~N}$, sin grandes cambios en el contenido de SST. Tras la simulación de comercialización a mercado Nacional se observó un descenso importante de la firmeza que puede llegar a comprometer la calidad del fruto, sobre todo cuando se recolecta a mediados de septiembre. Tras la simulación a mercados de la UE y EEUU, la firmeza cayó hasta valores cercanos a $10 \mathrm{~N}$, que han sido reportados como límite para comercializar los frutos de caqui (Besada et al., 2014) lo que refleja su sensibilidad a las bajas temperaturas. El tratamiento de 1-MCP aplicado no mejoró los valores de firmeza. No se ha encontrado información previa sobre el comportamiento de esta variedad bajo condiciones frigoríficas, únicamente en Japón se ha reportado que es apta para mantener a temperatura ambiente durante 12 días (Yamada et al., 2004).

\begin{tabular}{|l|l|l|l|l|}
\hline \multicolumn{1}{|c|}{ Variedad } & Septiembre & Octubre & Noviembre & Diciembre \\
\hline Soshu & & & & \\
Kanshu & & & & \\
Shinshu & & & & \\
Izu & & & & \\
Youhou & & & & \\
Koda Gosho & & & & \\
Cal Fuyu & & & & \\
Ichikikei Jiro & & & & \\
Suruga & & & & \\
Ban Gosho & & & & \\
Jiro & & & \\
Fuyu & & & \\
Isahaya & & & \\
O' Gosho & & & \\
\hline
\end{tabular}

Fig. 2. Periodo óptimo de recolección de las variedades estudiadas. 
Table 2. Índice de color (IC=1000a/Lb), SST ( ${ }^{\circ}$ Brix) y firmeza (N) en el momento de cosecha de las variedades estudiadas y valores de firmeza tras los diferentes escenarios de comercialización estudiados: mercado Nacional ( $N$ ) (7 días a $20{ }^{\circ} \mathrm{C}$ ), envío a países de la UE ( 5 días a $5{ }^{\circ} \mathrm{C}+5$ días a $20^{\circ} \mathrm{C}$ ) y envío a EEUU con tratamiento cuarentenario $\left(21\right.$ días a $0{ }^{\circ} \mathrm{C}+5$ días a $20^{\circ} \mathrm{C}$ ).

La coloración de la celda muestra la aptitud a las diferentes comercializaciones (verde: apto, naranja: la calidad puede verse comprometida, rojo: no apto).

Un asterisco $\left({ }^{*}\right)$ indica que un pretratamiento con 1-MCP previo a la conservación mejora la firmeza. Dos asteriscos $(* *)$ indica que un pretratamiento con 1-MCP previo a la conservación no mejora la firmeza.

\begin{tabular}{lcccccc}
\hline \multirow{2}{*}{ Variedad } & \multicolumn{3}{c}{ Cosecha } & \multicolumn{4}{c}{ Simulación de comercialización } \\
\cline { 2 - 7 } & $\begin{array}{c}\text { IC } \\
(1000 \mathrm{a} / \mathrm{Lb})\end{array}$ & $\begin{array}{c}\text { SST } \\
\left({ }^{\circ} \mathrm{Brix}\right)\end{array}$ & $\begin{array}{c}\text { Firmeza } \\
(\mathrm{N})\end{array}$ & $\mathrm{N}$ & $\begin{array}{c}\text { Firmeza (N) } \\
\text { UE }\end{array}$ & EEUU \\
\hline Soshu & $10-20$ & $15-16$ & $50-40$ & $25-10$ & $15-5$ & $<10^{* *}$ \\
Kanshu & $9-12$ & $17-19$ & $70-55$ & $60-45$ & $50-40$ & $<10$ \\
Shinshu & $7-12$ & $18-20$ & $65-40$ & $40-25$ & $30-15$ & $<10^{* *}$ \\
Izu & $11-19$ & $17-17.5$ & $40-35$ & $35-30$ & $25-20$ & $<10^{* *}$ \\
Youhou & $9-25$ & $16-17.5$ & $80-50$ & $70-40$ & $65-35$ & $35-20^{* *}$ \\
KodaGosho & $11-32$ & $16-18$ & $70-35$ & $65-30$ & $55-30$ & $<10^{* *}$ \\
Cal Fuyu & $10-23$ & $15-19$ & $60-30$ & - & $50-20$ & $<10^{* *}$ \\
Ichikikei Jiro & $20-30$ & $16-19$ & $60-50$ & $50-40$ & $45-30$ & $<10^{*}$ \\
Suruga & $15-20$ & $15-18$ & $55-45$ & $40-30$ & $40-30$ & $30-20$ \\
Ban Gosho & $18-20$ & $18-20$ & $60-50$ & $45-35$ & $40-30$ & $<10^{* *}$ \\
\hline Jiro & $10-25$ & $17-18$ & $65-50$ & - & $60-40$ & $20-10^{*}$ \\
Fuyu & $12-18$ & $16-19$ & $65-50$ & $60-45$ & $50-35$ & $35-25^{*}$ \\
Isahaya & $15-21$ & $15-18$ & $60-45$ & - & $45-35$ & $<10^{*}$ \\
\hline O' Gosho & $16-20$ & $14-16$ & $55-40$ & - & $50-25$ & $40-15^{*}$ \\
\hline
\end{tabular}


La variedad Kanshu se podría recolectar entre mitad de septiembre y mitad de octubre con una coloración anaranjada, alto contenido en SST y una pulpa con firmeza que se mantiene con valores muy elevados durante todo el periodo de recolección (entre $70 \mathrm{~N}$ y $55 \mathrm{~N}$ ). Para 'Shinshu', el momento de cosecha se estableció más corto, durante la primera quincena de octubre, con valores de índice de color y contenido de SST, similares a 'Kanshu' pero con una firmeza algo menor (65 N-40 N). La variedad Izu, se podría recolectar desde principio de octubre, con una coloración anaranjada (IC de 11), hasta finales de octubre con una coloración más rojiza (IC de 19), presentando durante todo este periodo valores de SST cercanos a $17^{\circ}$ Brix y firmeza no muy elevada, entre 40 $\mathrm{N}$ y $35 \mathrm{~N}$. Estas tres variedades 'Kanshu', 'Shinshu' e 'Izu', presentaron valores de firmeza aptos para su comercialización en el mercado Nacional. También presentaron valores comerciales tras la comercialización a la UE, aunque el importante descenso de la firmeza de 'Shinshu' podría comprometer su calidad cuando se cosecha a mitad de octubre. Las tres variedades presentaron un ablandamiento importante tras la comercialización a EEUU, indicando su elevada susceptibilidad a las bajas temperaturas. En el caso 'Shinshu' e 'Izu', se ensayó el tratamiento de 1-MCP previamente a los envíos a EEUU, pero no se mostró efectivo en ningún caso. En Japón también se ha reportado un tiempo de almacenamiento corto para 'Izu' con un descenso importante de la firmeza incluso a temperatura ambiente (Sato \& Yamada, 2003). Además, se ha reportado que las variedades 'kanshu' y 'Shinshu' son aptas para mantener a temperatura ambiente en Japón durante 15 y 8-10 días, respectivamente (Yamada \& Sato., 2003; Yamada et al., 2006).

'Youhou' y 'KodaGosho' se caracterizan por presentar un periodo de recolección bastante largo, entre la mitad de octubre y final de noviembre, con una coloración que varía entre tonalidades naranjas a tonalidades muy rojizas con IC muy altos, de 25 en el caso de 'Youhou' y 32 en el caso de 'Koda Gosho'. Ambas variedades presentaron un elevado contenido de SST durante todo el periodo de recolección establecido. A mitad octubre los frutos mostraron firmeza muy elevada $(80 \mathrm{~N}-70 \mathrm{~N})$, que descendió al final del periodo de cosecha hasta valores de $50 \mathrm{~N}$ para 'Youhou' y algo más para 'Koda Gosho' alcanzando valores de $35 \mathrm{~N}$ a final de noviembre. Las dos variedades mantuvieron altas firmezas tras la simulación al mercado Nacional y la 
comercialización a UE. Es importante destacar que, tras la comercialización de EEUU, la variedad Youhou mantuvo firmezas comerciales sin necesidad de aplicación de 1-MCP. Sin embargo 'Koda Gosho' mostró un ablandamiento drástico de la pulpa, que no se controló con la aplicación de 1-MCP. La baja sensibilidad a las bajas temperaturas mostrada por la variedad Youhou ha sido reportada previamente por Li et al. (2018).

Entre principios y final de noviembre se encuentran las variedades 'Cal Fuyu', 'Ichikikei Jiro', 'Suruga', 'BanGosho' y 'Jiro', las dos primeras pudiéndose recolectar incluso a finales de octubre. De estas variedades, las que presentaron las coloraciones más elevadas a principio del periodo de recolección establecido fueron 'Ichikikei Jiro' y 'Ban Gosho' con IC de 20 y 18 respectivamente. La variedad Ban Gosho destacó por presentar el mayor contenido de SST (18-20 ${ }^{\circ} \mathrm{Brix}$ ). Todas estas variedades a principio del periodo de recolección presentaron valores de firmeza elevados, entre $55 \mathrm{~N}$ y $65 \mathrm{~N}$ y el mayor descenso a finales de noviembre lo mostró 'Cal Fuyu' que se redujo hasta $30 \mathrm{~N}$. Las cinco variedades se mostraron aptas para su comercialización en el mercado Nacional y la UE. Sin embargo, la única que presentó firmeza comercial tras la comercialización a EEUU fue 'Suruga', con una firmeza entre $20 \mathrm{~N}$ y $30 \mathrm{~N}$. La variedad Jiro mostró valores de firmeza en el límite comercial que aumentaron con la aplicación de 1-MCP. 'Cal Fuyu', 'Ichikikei Jiro' y 'Ban Gosho' presentaron alta sensibilidad a las bajas temperaturas y la aplicación con 1-MCP solo se mostró efectiva en el caso de 'Ichikikei Jiro'. La baja sensibilidad de la variedad Suruga ha sido reportada previamente en Australia por Collins \& Tisdell, 1995. No se tiene información previa del resto de estas variedades.

Entre todas las variedades estudiadas, las más tardías son 'Fuyu', 'Isahaya' y O' Gosho, cuyo periodo de recolección se ha establecido entre mitad noviembre y mitad de diciembre. 'O' Gosho' destaca por presentar la mayor coloración a mitad de noviembre, pero con menor contenido de SST. Estas tres variedades presentaron una firmeza elevada siendo algo más baja la de la variedad O' Gosho. Tras la simulación de la comercialización a UE todas estas variedades presentaron firmeza comercial. La variedad Fuyu destacó por su baja sensibilidad a las bajas temperaturas mostrando tras la simulación a EEUU 
firmeza comercial, que aún se incrementó más con la aplicación de 1-MCP. La variedad O' Gosho mantuvo también firmeza elevada tras la comercialización a EEUU, sobre todo cuando se recolectó a principio de campaña con valores más elevados. En esta variedad también fue efectivo el 1-MCP. La variedad Isahaya se mostró susceptible a las bajas temperaturas, mostrando un ablandamiento drástico tras la comercialización a EEUU, sin embargo, con la aplicación de 1MCP se consiguió reducir la perdida de firmeza, manteniendo valores comerciales.

\section{Conclusiones}

El periodo de recolección de las diferentes variedades estudiadas se estableció desde principios de septiembre, siendo 'Soshu' la más temprana, hasta mitad de diciembre con las variedades 'Fuyu', 'Isahaya' y 'O'gosho'. En general, todas las variedades se mostraron aptas para ser comercializadas a mercado Nacional y países de la UE.

La simulación de los envíos a EEUU, bajo condiciones de cuarentena por frio permitió conocer la sensibilidad de estas variedades a las bajas temperaturas. Las variedades 'Youhou', 'Suruga', 'Fuyu' y O'Gosho destacaron por su baja sensibilidad, mostrando firmeza comercial tras la comercialización a EEUU, mientras que el resto de variedades experimentaron un ablandamiento drástico, comprometiendo su calidad en destino. Por otra parte, la efectividad de la aplicación del 1-MCP dependió de la variedad en la que se ensayó. Así, el tratamiento mejoró la firmeza en las variedades 'Ichikikei Jiro', 'Jiro', 'Fuyu', 'Isahaya' y 'O'Gosho' mientras que en otras variedades no tuvo ningún efecto.

\section{Agradecimientos}

Este estudio ha sido financiado por el Instituto Nacional de Tecnología Agraria y Alimentaria de España (INIA) con el apoyo de fondos FEDER a través de los proyectos RTA2013-00043-C02-01 y RTA2017-00045-C02-01. Ayoub Fathi Najafabadi agradece a INIA por la ayuda FPIINIA \#43 (CPD2015-0151). Los 
autores agradecen a la Cooperativa Agrícola Ntra Sra de L'Oreto y a Anecoop S. Coop. por el apoyo técnico y la colaboración en el desarrollo de los estudios.

\section{Bibliografía}

Arnal L., \& Del Río, M.A. (2004). Effect of cold storage and removal astringency on quality of persimmon fruit (Diospyros kaki, L) cv. Rojo Brillante. Food Science and Technology International. 10 (3). In press. https://doi.org/10.1177/1082013204044824

Besada, C., Arnal, L., \& Salvador, A. (2008). Improving storability of persimmon cv. Rojo Brillante by combined use of preharvest and postharvest treatments. Postharvest Biology and Technology. 50, 169-175. https://doi.org/10.1016/j.postharvbio.2008.05.013

Besada, C., Novillo, P., Navarro, P., \& Salvador, A. (2014). Effect of a low oxygen atmosphere combined with 1-MCP pretreatment on preserving the quality of 'Rojo Brillante' and 'Triumph' persimmon during cold storage. Scientia Horticulturae. 179, 51-58. https://doi.org/10.1016/j.scienta.2014.09.015

Besada, C., \& Salvador, A. (2018). Postharvest Biology and Technology of Persimmon. In: Mir S., Shah M., Mir M. (eds) Postharvest Biology and Technology of Temperate Fruits. Springer, Cham, pp. 371-393. https://doi.org/10.1007/978-3-319-76843-4_16

Collins, R.J., \& Tisdell, J.S. (1995). The influence of storage time and temperature on chilling injury in 'Fuyu' and 'Suruga' persimmon (Diospyros kaki L.) grown in subtropical Australia. Postharvest Biology and Technology. 6(1, 2), 149-157. https://doi.org/10.1016/09255214(94)00046-U

Krammes, J.G., Argenta, L.C., \& Vieira, M.J. (2006). Influences of 1methylcyclopropene on quality of persimmon fruit cv. 'Fuyu' after cold 
storage. Acta Horticulturae. 727, 513-518. https://doi.org/10.17660/ActaHortic.2006.727.63

Li, J., Han, Y., Hu, M., Jin, M., \& Rao, J. (2018). Oxalic acid and 1methylcyclopropene alleviate chilling injury of 'Youhou' sweet persimmon during cold storage. Postharvest Biology and Technology. 137, 134-141. https://doi.org/10.1016/j.postharvbio.2017.11.021

MacRae, E. A. (1987). Development of chilling injury in New Zealand grown 'Fuyu' persimmon during storage. New Zealand Journal of Experimental Agriculture. 15 , 333-344. https://doi.org/10.1080/03015521.1987.10425579

Novillo, P., Salvador, A., Magalhaes, T., \& Besada, C. (2014). Deastringency treatment with $\mathrm{CO} 2$ Induces oxidative stress in persimmon fruit. Postharvest Biology and Technology. 92, 16-22. https://doi.org/10.1016/j.postharvbio.2013.12.019

Salvador, A., Arnal, L., Monterde, A., \& Cuquerella, J. (2004). Reduction of chilling injury symptoms in persimmon fruit cv. Rojo Brillante by 1-MCP. Postharvest Biology and Technology. 33, 285-291. https://doi.org/10.1016/j.postharvbio.2004.03.005

Salvador, A., Arnal, L., Besada, C., Larrea, V., Quiles, A., \& Pérez-Munuera, I. (2007). Physiological and structural changes during ripening and deastringency treatment of persimmon fruit cv. 'Rojo Brillante'. Postharvest Biology and Technology. 46 (2), 181-188. https://doi.org/10.1016/j.postharvbio.2007.05.003

Sato, A., \& Yamada, M. (2003). Leading persimmon cultivars for commercial production and breeding targets in Japan. Acta Horticulturae. 601, 25-30. https://doi.org/10.17660/ActaHortic.2003.601.2

Tsviling, A., Nerya, O., Gizis, A., Sharabi-Nov, A., \& Ben-Arie, R. (2003). Extending the shelf-life of 'Triumph' persimmons after storage, with 1MCP. Acta Horticulturae. 599, 53-58. https://doi.org/10.17660/ActaHortic.2003.599.4 
Woolf, A.B., Ball, S., Spooner, K.J., Lay-Yee, M., Ferguson, I.B., Watkins, C.B., Gunson, A., \& Forbes, S.K. (1997). Reduction of chilling injury in the sweet persimmon 'Fuyu' during storage by dry air heat treatments. Postharvest Biology and Technology. 11, 155-164. https://doi.org/10.1016/S09255214(97)00024-0

Yamada, M., \& Sato, A. (2003). Persimmon cultivars released in the 1990 s by the national institute of fruit tree science in Japan. Acta Horticulturae. 601, 19-23. https://doi.org/10.17660/ActaHortic.2003.601.1

Yamada, M., Yamane, H., Sato, A., Iwanami, H., Hirakawa, N., Yoshinaga, K., Ozawa, T., \& Nakajima, I. (2004). New Japanese Persimmon Cultivar 'Soshu'. Bulletin of the National Institute of Fruit Tree Science. 3, 53-66.

Yamada, M., Sato, A., Yamanae, H., Yoshinaga, K., Hirakawa, N., Iwanami, H., Ozawa, T., Kakutani, M., Mitani, N., Yoshioka, M., \& Nakajima, I. (2006). New Japanese persimmon cultivar 'Kanshu'. Bulletin of the National Institute of Fruit Tree Science. 5, 95-106. 
IV. GENERAL DISCUSSION 



\section{IV.1. THE OPTIMIZATION OF POSTHARVEST TECHNOLOGIES TO IMPROVE FRUIT QUALITY OF 'ROJO BRILLANTE' PERSIMMON}

\section{IV.1.1. Postharvest technology to guarantee fruit quality on arrival at overseas markets}

In recent years, the exportation of 'Rojo Brillante' persimmon to overseas countries has been increasing significantly. So, one of the current challenges is to reach international markets with the required fruit quality.

The fruit of 'Rojo Brillante' are astringent at harvest due to the high concentration of soluble tannins. The usual commercial practice to remove astringency before commercialization is to submit the fruit to a high concentration of $\mathrm{CO}_{2}(95 \%-98 \%)$ at $20{ }^{\circ} \mathrm{C}$ for $24 \mathrm{~h}$ (Salvador et al., 2007). Furthermore, as the fruit of this variety are sensitive to $\mathrm{Cl}$, they are normally treated with 1-MCP before storing or shipping at low temperatures in order to retard the manifestation of chilling symptoms (Besada et al., 2008, 2014).

These two technologies have played a crucial role in the marked expansion of 'Rojo Brillante' in the last two decades. However, when this Thesis began, some postharvest challenges existed in the case of shipments of fruit to overseas destinations. Thus, in this market scenario, one of the most important causes of postharvest losses of 'Rojo Brillante' was the manifestation of internal flesh browning disorder after cold-stored shipment for a relatively long period. Therefore, one of the objectives of this Thesis was to elucidate the factors involved in this alteration and to find solutions to prevent it.

The starting point for this study was that browning had been mainly observed after shipment at low temperatures, but it was not frequently manifested when fruit were maintained in cool stores in packing houses to prolong the season. The main difference between these two scenarios was the moment of application of the $\mathrm{CO}_{2}$ treatment. Thus, when fruit is kept at low temperatures for a long time, it is recommended that $\mathrm{CO}_{2}$ deastringency treatment should be applied after storage to avoid loss of firmness. However, it is impossible to follow this recommendation when fruit are sent to overseas markets, as astringency needs to be removed before shipment. Thus, $\mathrm{CO}_{2}$ treatment was hypothesized to play a role in the development of flesh browning. 
The general recommendation is to attemperate the fruit after the $\mathrm{CO}_{2}$ treatment to help complete the deastringency process, especially when the treatment is applied at lower temperatures or for a shorter duration than the standard conditions $\left(20^{\circ} \mathrm{C}, 24 \mathrm{~h}\right)$. Nevertheless, this practice is not always carried out in the packing houses due to logistical issues. Moreover, deastringency treatment is applied at ambient temperature in some packing houses because of a lack of temperature control in the chambers. Hence, $\mathrm{CO}_{2}$ treatment temperature and the temperature at which the fruit is kept after the deastringency treatment could be involved in the browning disorders that were evaluated during the Thesis.

The implication of these two factors in browning manifestation was evaluated in Chapter I. Thus, the $\mathrm{CO}_{2}$ treatment was assayed at two different temperatures $\left(12{ }^{\circ} \mathrm{C}\right.$ and $20^{\circ} \mathrm{C}$ ) followed (or not) by an attemperation period of $24 \mathrm{~h}$ at $20^{\circ} \mathrm{C}$ before fruit storage at $0{ }^{\circ} \mathrm{C}$ for up 41 days.

When fruit were stored at a low temperature immediately after being taken out of the $\mathrm{CO}_{2}$ chambers, the internal flesh browning appeared after the shelflife period. In contrast, the fruit attempered before storing at $0{ }^{\circ} \mathrm{C}$ did not show any internal flesh disorder. Moreover, this alteration was more severe when the astringency treatment was applied at $20^{\circ} \mathrm{C}$ than at $12{ }^{\circ} \mathrm{C}$. In this study, internal browning was linked to a high concentrations of acetaldehyde accumulated inside the fruit at the time to be cold stored. This is in accordance with other authors who, in other fruits, linked high acetaldehyde levels with reactive oxygen species (ROS) accumulation and cell damage (Drew, 1997; Purvis, 2001; Apel \& Hirt, 2004; Ho et al., 2009). Furthermore, it has been reported that the principal structural change that persimmon 'Rojo Brillante' fruit undergo during cold storage is a loss of cell wall integrity and low intracellular adhesion (Pérez-Munuera et al., 2009). So, during prolonged cold storage of the fruit, cell membranes might lose their integrity, and the ROS generated as consequence of a high level of acetaldehyde could come into contact with tannins, oxidize them, with the subsequent manifestation of browning.

After identifying the $\mathrm{CO}_{2}$ treatment as the main factor involved in flesh browning that appeared after prolonged shipment at low temperature, the 
search for alternative deastringency treatments became one of the goals of this Thesis.

The treatment with ethanol vapor has traditionally been used as a deastringency method in some countries like Japan (Taira et al., 1989). It is still the most widely used treatment for astringency removal in Brazil today (Tessmer et al., 2018).

In Chapter II of this Thesis the possibility of developing a new deastringency method based on ethanol was evaluated. Nevertheless, in this case, ethanol was not applied in the form of vapor but by applying an edible coating that includes ethanol in its formulation. This coating was developed by the Fomesa Fruitech S.L.U. Company in collaboration with our Research Center.

The objective of this study was to determine the efficiency for astringency removal of the new ethanolic wax combined with a plastic film packaging under the main commercialization scenarios. Our results showed that this waxing method worked perfectly as a method to remove astringency after storing the fruit for 30 days at $0{ }^{\circ} \mathrm{C}$ and after a shelf-life period that followed 15 and 21 days' cold storage, with high fruit firmness being maintained in both 'Rojo Brillante' and 'Triumph' cultivars. Moreover, while the $\mathrm{CO}_{2}$ treated fruit showed flesh browning after prolonged cold storage, the fruit treated with the ethanolic wax maintained a good internal quality throughout the entire period under study without manifesting any internal disorder. The new method could therefore be a good alternative to the application of $\mathrm{CO}_{2}$ to preserve fruit quality when prolonged cold storage is required, as in the case of shipments of the product to distant overseas destinations.

\section{IV.1.2. Pre- and postharvest methods to guarantee fruit quality after cold storage in packing houses}

The production of 'Rojo Brillante' is concentrated in a short period, and thus fruit storage at low temperature after harvest, mainly at the end of the season, has become a habitual practice to extend the marketing season. Applying 1MCP treatment is currently the tool used to minimize the loss of product quality linked with $\mathrm{Cl}$ during storage. Extending the commercial period 
remains, however, a challenge for persimmon producers, which would result in greater economic profits for the sector.

In this context, one of the approaches of this Thesis consists in combining preand postharvest treatments to extend the commercial period of 'Rojo Brillante' persimmon. Gibberellic acid (GA) is one of the most widely studied preharvest treatments to delay the harvest time of persimmon fruits (Agustí et al., 2004; Besada et al., 2008). It has been reported that the application of GA when persimmon is at the color-break stage brings about a delay in fruit maturity, retarding the color change and slowing down the flesh softening (Ben-Arie et al., 1996, 1997; Agustí et al., 2003, 2004). The studies carried out so far show the effect of a single application of GA. Nevertheless, GA can be applied up to three times, but there is no information about the advantages of these multiple applications in terms of the delay in fruit ripening or the postharvest behavior.

Thus, in Chapter III, a study was conducted to evaluate the effect of one, two or three applications of GA in the preharvest period on fruit quality during maturation. In addition, the influence of the different applications of GA on postharvest fruit quality was also studied. To do so, fruit were harvested at three times during the season and were stored at $0{ }^{\circ} \mathrm{C}$ for 30 and 60 days followed by 5 days at $20^{\circ} \mathrm{C}$, simulating the shelf-life period.

The results showed that two applications of GA enhanced the delay in fruit maturation with respect to the effect caused by a single application. Nevertheless, a third application of GA did not offer any additional effect compared to that resulting from two applications.

On the other hand, this study confirms that the application of GA in preharvest in combination with the postharvest 1-MCP (Smartfresh ${ }^{\circledR}$ ) treatment made it possible to preserve a higher quality of the 'Rojo Brillante' persimmon during cold storage compared to the application of Smartfresh ${ }^{\circledast}$ alone.

In the first harvest, carried out in the middle of November, the GA treatment, regardless of the number of applications, allowed storage for up to 60 days, maintaining high fruit firmness after the shelf-life period, compared with the fruit in which GA was not applied. 
In the following harvests, at the end of November and in early December, the GA treatment allowed the fruit quality to be maintained during 30 days of cold storage, and the fruit showed greater firmness with 2-3 GA applications compared to a single application. Nevertheless, fruit quality could be compromised when fruit were stored for 60 days.

In addition to the delay in fruit maturation, we investigated whether GA is capable of delaying the senescence of the calyx, since the calyx is a very characteristic part of the persimmon fruit.

The fruit ripening on tree is accompanied by desiccation and browning of the calyx lobes, which is associated with a loss of freshness of the persimmon fruit. Until now, no information has existed about the relationship between calyx senescence and the physicochemical changes that occur in persimmon treated with or without GA during fruit ripening.

Chlorophyll fluorescence imaging (CFI) is a rapid, inexpensive, and nonintrusive technique that is widely used to evaluate plant photosynthetic activity. The efficiency of this method to determine the ripening stage of some fruits has been reported before by other authors (Bron et al., 2004, 2005; Lu et al., 2012). However, there is no information about applying the CFI technique to monitor the photosynthetic activity of the calyx during persimmon fruit maturation.

Therefore, in Chapter IV, the effect of GA on calyx senescence by means of the $\mathrm{CFI}$ technique and the relationship between chlorophyll fluorescence parameters in the calyx and fruit quality parameters were evaluated.

In this study, physicochemical parameters in fruit and CFI parameters (Fo, Fm and $\mathrm{Fv} / \mathrm{Fm}$ ) in the calyx lobes were evaluated at three harvest times on fruit treated once or twice with GA, and fruit without any treatment (control).

All the chlorophyll fluorescence parameters measured in the calyx declined during fruit ripening on the tree. Spatial image heterogeneity in the measurements of $\mathrm{Fm} / \mathrm{Fv}$ explains the symptoms of senescence and necrosis that begin in the apical area of the calyx lobes and progress to the basal area. $\mathrm{GA}$, besides retarding fruit ripening, delays the senescence process in the calyx, thereby improving the external fruit quality. The CFI parameters measured in 
the calyx were correlated with the increase in external color and with the loss of firmness during fruit ripening.

Another challenge associated with storing the fruit is to preserve the persimmon produced in the organic condition, since 1-MCP cannot be used. Nowadays, there is great demand for organic production, not only in Spain, but also in other European countries (Jensen et al., 2011). Therefore, improving the storage methods to preserve fruit quality is of the greatest importance in the organic agriculture sector.

Hence, in Chapter $\mathbf{V}$, the optimum conditions to store organic persimmon while preserving fruit quality were studied. To this end, the effect of different storage temperatures $\left(0{ }^{\circ} \mathrm{C}\right.$ and $15{ }^{\circ} \mathrm{C}$ ), storing duration (up to 30 days), maturity stage (two harvests), and moment of application of the deastringency treatment (before or after cold storage) were evaluated.

The maturity stage was a key factor in the preservation of fruit quality during cold storage. So, only the fruit harvested with flesh firmness values above $30 \mathrm{~N}$ could be stored. Moreover, the storage time also depended on the temperature and the moment of $\mathrm{CO}_{2}$ deastringency application. Fruit stored at $0{ }^{\circ} \mathrm{C}$, before being treated by $\mathrm{CO}_{2}$, showed a commercial quality for two weeks. However, when the deastringency treatment was applied before cold storage, severe $\mathrm{Cl}$ symptoms were manifested, and the quality of the fruit was not acceptable. The fruit treated by $\mathrm{CO}_{2}$ and then stored at $15{ }^{\circ} \mathrm{C}$ exhibited commercial quality until three weeks of storage. Yet, when $\mathrm{CO}_{2}$ treatment was applied after storage at $15{ }^{\circ} \mathrm{C}$, the deastringency treatment was not effective and fruit remained astringent and inedible. As Salvador et al. (2008) reported, this fact is associated with difficult diffusion of $\mathrm{CO}_{2}$ due to loss of initial flesh structure of the fruit. Since until now the organic persimmon was not being stored, these results are very useful for organic persimmon producers to export the fruit under adequate conditions. 


\section{IV.2. EVALUATION OF POSTHARVEST BEHAVIOR OF CULTIVARS INTRODUCED FROM OTHER COUNTRIES UNDER MEDITERRANEAN CONDITIONS}

Persimmon production in Spain is currently based on two varieties: 'Rojo Brillante' and 'Triumph'. This implies a significant phytosanitary risk, as well as a commercial limitation related to the harvest period. Thus, a common challenge for persimmon producers and researchers is to introduce new varieties that allow the varietal range of the persimmon to be extended. Moreover, it is of special interest to introduce non-astringent varieties (PCNA), which do not need any postharvest deastringency, in order to simplify postharvest fruit handling. In accordance with these objectives, a breeding program has been carried out at IVIA since 2002 (Martínez Calvo et al., 2018). As part of this program, a germplasm bank with cultivars from different geographical persimmon production areas has been created in order to evaluate their response under our Mediterranean agroclimatic conditions. The differences in climate between growing regions can influence the harvest time and fruit quality (Soqanloo, 2015; Zanamwe, 2018).

It should be remembered that the success of a new variety depends not only on its agronomic behavior but also on its postharvest behavior to guarantee quality during its marketing (Kader \& Yahia, 2011).

In Chapters VI and VII of this Thesis, the optimal harvest period and postharvest behavior of 14 non-astringent persimmon varieties belonging to the IVIA germplasm bank were evaluated. A characterization of fruit maturity was performed for each variety. Taking into account that the changes in external color are linked to the main physicochemical changes during persimmon maturation, the fruit skin color was periodically measured between mid-August and the end of December. This made it possible to establish the moment of color change (from green to orange) and the period in which the fruit achieved a homogeneous orange-red color for each variety under study. Moreover, fruit were harvested at different stages of maturity to evaluate the quality at the time of harvesting and after being submitted to different commercial scenarios (domestic market, transport to EU countries, or shipping to countries with quarantine treatment like USA). 
For the varieties studied, the harvest period was established from the beginning of September with 'Soshu', the earliest, until mid-December with 'Fuyu', 'Isahaya' and 'O'gosho'.

In general, almost all the varieties showed good quality after simulating commercialization on domestic and EU markets. The simulation of the conditions involved in shipments to the USA, under quarantine cold treatment, revealed the different sensitivity of these varieties to low temperatures. 'Youhou', 'Suruga', 'Fuyu', and O'Gosho stood out for their low sensitivity, showing commercial firmness after marketing to the USA. The rest of the varieties exhibited symptoms of $\mathrm{Cl}$ when the fruit were submitted to cold storage, manifesting a drastic softening, after simulating commercialization to USA. When a preteatment with 1-MCP was applied in order to control for $\mathrm{Cl}$, its effect depended on the variety. Thus, 1-MCP improved firmness in varieties like 'Ichikikei Jiro ', 'Jiro', 'Fuyu', 'Isahaya', and 'O'Gosho', while in other varieties it had no effect.

The results of these studies, besides providing information about those varieties that may sucessfully increase the varietal range in our growing area, could be used by persimmon breeders to obtain new plant material with desirable characteristics.

\section{References}

Agustí, M., Juan, M., Yagüe, B., Mesejo, C., Martínez-Fuentes, A., \& Almela, V. (2003). Tratamientos para retrasar la maduración del fruto del caqui (Dyospiros kaki L.). CV Agraria. 24, 27-33.

Agustí, M., Juan, M., Martínez-Fuentes, A., Mesejo, C., \& Almela, V. (2004). Calcium nitrate delays climacteric of persimmon fruit. Annals of Applied Biology. 144, 65-69. https://doi.org/10.1111/j.1744-7348.2004.tb00317.x

Apel, K., \& Hirt, H. (2004). Reactive oxygen species: metabolism, oxidative stress, and signal transduction. Annual Review of Plant Biology. 55, 373399. https://doi.org/10.1146/annurev.arplant.55.031903.141701 
Ben-Arie, R., Saks, Y., \& Sonego, L. (1996). Cell wall metabolism in gibberellintreated persimmon fruits. Plant Growth Regulation. 19, 25-33. https://doi.org/10.1007/BF00024399

Ben-Arie, R., Zhou, H.W., Sonego, L., \& Zutkhi Y. (1997). Plant growth regulator effects on the storage and shelf-life 'Triumph' persimmons. Acta Horticulturae. 436 , 243-250. https://doi.org/10.17660/ActaHortic.1997.436.26

Besada, C., Arnal, L., \& Salvador, A. (2008). Improving storability of persimmon cv. Rojo Brillante by combined use of preharvest and postharvest treatments. Postharvest Biology and Technology. 50, 169-175. https://doi.org/10.1016/j.postharvbio.2008.05.013

Besada, C., Novillo, P., Navarro, P., \& Salvador, A. (2014). Effects of a low oxygen atmosphere with 1-MCP pre-treatment on preserving the quality of 'Rojo Brillante' and 'Triumph' persimmons during cold storage. Scientia Horticulturae. 179, 51-58. https://doi.org/10.1016/j.scienta.2014.09.015

Bron, I.U., Ribeiro, R.V., Azollini, M., Jacomino, A.P., \& Machado, E.C. (2004). Chlorophyll fluorescence as a tool to evaluate the ripening of 'Golden' papaya fruit. Postharvest Biology and Technology. 33, 163-173. http://doi.org/10.1016/j.postharvbio.2004.02.004

Bron, I.U., Ribeiro, R.V., Azzolini, M., Machado, E. C., \& Jacomino, A. P. (2005). Chlorophyll fluorescence emission and its relation to skin color and firmness during ripening of guava fruit. Fruits. 60(1), 25-32. https://doi.org/10.1051/fruits:2005009

Drew, M.C. (1997). Oxygen deficiency and root metabolism: injury and acclimation under hypoxia and anoxia. Annual Review of Plant Physiology and Plant Molecular Biology. 48, 223-250. https://doi.org/10.1146/annurev.arplant.48.1.223

Ho, Q.T., Verboven, P., Mebatsion, H.K., Verlinden, B.E., Vandewalle, S., \& Nicolai, B.M. (2009). Microscale mechanisms of gas exchange in fruit 
tissue. New Phytologist. 182, 163-174. https://doi.org/10.1111/j.14698137.2008.02732.x

Jensen, K. O. D., Denver, S., \& Zanoli, R. (2011). Actual and potential development of consumer demand on the organic food market in Europe. NJAS-Wageningen Journal of Life Sciences. 58(3-4), 79-84. https://doi.org/10.1016/j.njas.2011.01.005

Kader, A., \& Yahia, E. (2011). Postharvest biology of tropical and subtropical fruits. Postharvest Biology and Technology of Tropical and Subtropical Fruits. 79-111. https://doi.org/10.1533/9780857093622.79

Lu, H., Lou, H., Zheng, H., Hu, Y., \& Li, Y. (2012). Nondestructive evaluation of quality changes and the optimum time for harvesting during jujube (Zizyphus jujube Mill. cv. Changhong) fruits development. Food and Bioprocess Technology. 5, 2586-2595. https://doi.org/10.1007/s11947011-0640-5

Martínez-Calvo, J., Climent, J., Naval, M.M., \& Badenes, M.L. (2018). The I.V.I.A. germplasm collection of persimmon (Diospyros kaki Thunb.). Acta Horticulturae. 1195 ,

55-60.

https://doi.org/10.17660/ActaHortic.2018.1195.9

Pérez-Munuera, I., Hernando, I., Larrea, V., Besada, C., Arnal, L., \& Salvador, A. (2009). Microstructural study of chilling injury alleviation by 1 methylcyclopropene in persimmon. HortScience. 44, $742-745$. https://doi.org/10.21273/hortsci.44.3.742

Purvis, AC. (2001). Reduction of superoxise production by mitochondria oxidizing NADH in the presence of organic acids. Journal of Plant Physiology. 158, 159-165. https://doi.org/10.1078/0176-1617-00128

Salvador, A., Arnal, L., Besada, C., Larrea, V., Hernando, I., \& Pérez-Munuera, I. (2008). Reduced effectiveness of the treatment for removing astringency in persimmon fruit when stored at $15{ }^{\circ} \mathrm{C}$ : Physiological and microstructural study. Postharvest Biology and Technology. 49, 340-34. https://doi.org/10.1016/j.postharvbio.2008.01.015 
Salvador, A., Arnal, L., Besada, C., Larrea, V., Quiles, A., \& Pérez-Munuera, I. (2007). Physiological and structural changes during ripening and desastringency treatment of persimmon fruit 'RojoBrillante'. Postharvest Biology and Technology. $46 \quad$ (2), 181-188. https://doi.org/10.1016/j.postharvbio.2007.05.003

Soqanloo, S.S. (2015). Effect of different regional climates on persimmon quality. Journal of Civil Engineering and Environmental Sciences. 1(1), 008012. DOI: $10.17352 / 2455-488 X .000003$

Taira, S., Itamura, H., Abe, K., \& Watanabe, S. (1989). Comparison of the characteristics of removal of astringency in two Japanese persimmon (Diospyros kaki) cultivars, Denkuro and Hiratanenashi. Journal of the Japanese Society for Horticultural Science. 58(2), 319-325. https://doi.org/10.2503/jjshs.58.319

Tessmer, M.A., Da Glória, B.A., \& Kluge, R.A. (2018). Astringency reduction using ethanol-associated to the storing under refrigeration at $5^{\circ} \mathrm{C}$ promotes physiological and structural alterations in "Giombo" persimmons. Comunicata Scientiae. 9(3), 449-456. https://doi.org/10.14295/CS.v9i3.2014

Zanamwe, P. (2018). Effects of production area and harvest maturity on postharvest quality of South African 'Triumph' persimmon fruit (diospyros kaki). African Journal of Horticultural Science. 13, 31-42. 



\section{GENERAL CONCLUSIONS}



- The main factor involved in the manifestation of internal flesh browning after long cold storage of 'Rojo Brillante' persimmon is the temperature to which the fruit is exposed after the $\mathrm{CO}_{2}$ deastringency treatment. An attemperation period after the $\mathrm{CO}_{2}$ treatment facilitates the diffusion of $\mathrm{CO}_{2}$ out of the fruit, which results in lower acetaldehyde accumulation, thus preventing the manifestation of internal flesh browning.

- The patented method based on a new wax containing ethanol is an effective treatment to remove astringency during prolonged cold storage of persimmon 'Rojo Brillante' and 'Triumph'. This method can be an alternative to $\mathrm{CO}_{2}$ treatment to prevent internal disorders when long cold storage is required.

- The multiple application of GA delays the fruit maturity process on the tree. Two GA applications have a better effect on retarding fruit ripening than a single application, resulting in higher fruit firmness on tree. Moreover, the combination of preharvest GA application with postharvest 1-MCP treatment allows cold storage to be prolonged while preventing the appearance of chilling injury symptoms.

- The GA preharvest treatment, besides retarding fruit ripening on the tree, delays the senescence of the calyx, thereby improving the external appearance of the fruit. The calyx senescence process during fruit maturation is correlated to a decline in the chlorophyll fluorescence parameters (Fo, Fm, and Fv/Fm). Moreover, the changes in CFI parameters are also correlated with the loss of firmness and increased color during fruit ripening.

- Correct postharvest handling allows organic persimmon to be stored for up to three weeks. Maturity stage at harvest, storage temperature, and the moment of $\mathrm{CO}_{2}$ deastringency treatment are key factors in the final fruit quality. Fruit harvested with firmness values lower than $30 \mathrm{~N}$ should not be stored. The maximum storage period was achieved when fruit were harvested with a flesh firmness above $45 \mathrm{~N}$ and submitted to the $\mathrm{CO}_{2}$ deastringency treatment before storage at $15^{\circ} \mathrm{C}$. 
- Fourteen non-astringent varieties belonging to the IVIA germplasm bank were studied. For each variety, the optimal harvest time and the postharvest behavior under the main marketing scenarios were determined. Some of these cultivars are very interesting candidates to expand the persimmon varietal range under Mediterranean growing conditions. 